Andrews University

Digital Commons @ Andrews University

Professional Dissertations DMin

Graduate Research

1977

\title{
The Seventh-day Adventist Family in Japan
}

Warren Ivan Hilliard

Andrews University

Follow this and additional works at: https://digitalcommons.andrews.edu/dmin

Part of the Practical Theology Commons

\section{Recommended Citation}

Hilliard, Warren Ivan, "The Seventh-day Adventist Family in Japan" (1977). Professional Dissertations DMin. 557.

https://dx.doi.org/10.32597/dmin/557

https://digitalcommons.andrews.edu/dmin/557

This Project Report is brought to you for free and open access by the Graduate Research at Digital Commons @ Andrews University. It has been accepted for inclusion in Professional Dissertations DMin by an authorized administrator of Digital Commons @ Andrews University. For more information, please contact repository@andrews.edu. 
ABSTRACT

THE SEVENTH-DAY ADVENTIST FAMILY IN JAPAN

by

Warren Ivan Hilliard

Chairperson: Rudolf E. Klimes 


\title{
ABSTRACT OF GRADUATE STUDENT RESEARCH
}

Project

\author{
Andrews University
}

Seminary

\begin{abstract}
Title: THE SEVENTH-DAY ADVENTIST FAMILY IN JAPAN
Name of researcher: Warren Ivan Hilliard

Name and title of faculty adviser: Rudolf E. Klimes, Ph.D.

Date completed: January 1977
\end{abstract}

\section{Problem}

There are indications that failure on the part of Christian workers in Japan to develop a family-centered strategy of evangelism based on a balanced appreciation of the cultural integrity of that country has contributed to the slow growth of Christianity. The Seventh-day Adventist Church, while stressing the importance of the family, has largely failed to understand the Japanese family and to realize its potential for evangelism.

\section{Method}

The project was organized in two parts. As the Seventh-day Adventist family in Japan was seen to be first of all Japanese, a review of the literature concerning the characteristics and 
development of the traditional Japanese family was undertaken. Secondly, survey instruments were designed and sent to all 1870 Adventist spouses of united families, to a sample of 81 Seventhday Adventist spouses of divided families, to all 108 Seventhday Adventist ministers, and to a sample of 192 unmarried Seventhday Adventist youth, seeking information that would help to gain a clearer understanding of the Adventist family and how it might be strengthened and made more effective in evangelism.

\section{Results}

A survey of the literature indicated that the traditional Japanese family possessed both great strengths and weaknesses. Social and political changes in recent years were noted that have weakened the traditional family system. However, the emergence of a nuclear-conjugal family was not seen as implying the demise of those characteristics that had developed over the centuries. Remnants of the old patterns of thinking and behavior are still in evidence in Japanese society today, in spite of impressive changes.

Data in 127 tables and six graphs described the characteristics of the Seventh-day Adventist family. Yearly family income was seen as similar to the average reported family income in Japan, whereas the education level of Adventist spouses was considerably higher than the average. Nearly one out of three of the major wage earners in Adventist families earned his living from the church, and the ratio of female to male members was seen to be more than three to one. Nearly six out of ten Adventist families sent all 
their children to Adventist schools and one out of four Adventist spouses hoped that their first born son would become a doctor or a specially trained worker in some medically related profession. As evaluated by their pastors, 65 percent of the membership of the church were seen as faithful to the church when both husband and wife were church members, in contrast to 45 percent when they were single, married to non-members, divorced, or widowed. Among the results of this study were numerous insights and convictions in connection with the family, some of which arose directly as a result of this project and others which have been deepened by it. Recommendations were developed that would hopefully lead to stronger families in the Seventh-day Adventist Church and to a family-centered approach to evangelism. 
Andrews University

Seventh-day Adventist Theological Seminary

THE SEVENTH-DAY ADVENTIST FAMILY IN JAPAN

\author{
A Research Report \\ Presented in Partial Fulfillment \\ of the Requirements for the Degree \\ Doctor of Ministry
}

by

Warren Ivan Hilliard

January 1977 

THE SEVENTH-DAY ADVENTIST FAMILY IN JAPAN

\author{
A project presented
}

in partial fulfillment of the requirements

for the degree

Doctor of Ministry

by

Warren Ivan Hilliard

APPROVAL BY THE COMMITTEE:

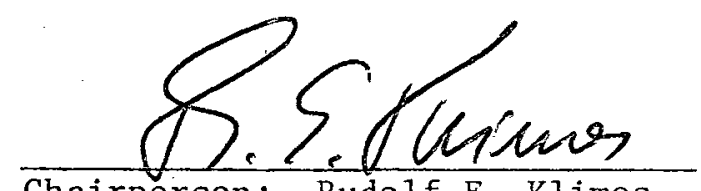

chais

ison: Rudolf

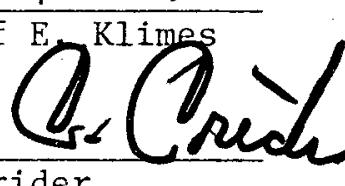

Charles C. Crider

Cobert C. Ketter

Robert C. Kistier
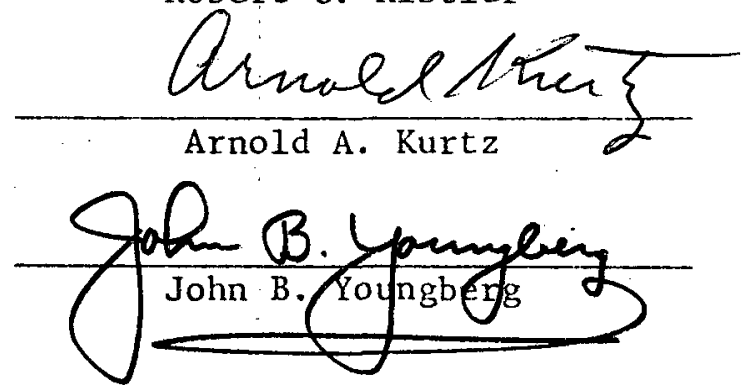

$4 / 22 / 77$

Date approved

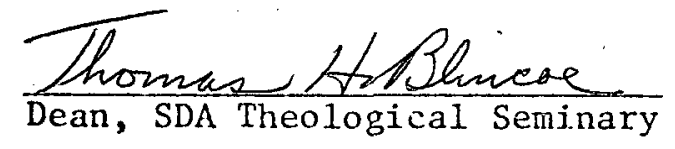


LIST OF TABLES • • . . . . . . . . • • • • • • • • • • • viii

LIST OF FIGURES . . . . . . . . . . . . . . . . . . . xiv

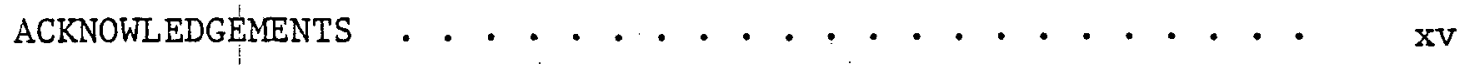

Chapter

I. INTRODUCTION . . . . . . . . . . . . . . . 1

The Problem . . . . . . . . . . . . . . 3

Importance of the Family in
the Divine Plan .... . . . . . . . . . . . 6

Purpose of the Study . . . . . . . . . . . . . 8

Importance of the Study ...... . . . . . . . . 9

Outline of the Study . . . . . . . . . . . . . 11

Definition of Terms . . . . . . . . . . . . 13

Delimitations . . . . . . . . . . . . . . 14

Personal Expectations . . . . . . . . . . . . 15

II. THE TRADITIONAL JAPANESE FAMILY . . . . . . . . . . . 17

Structure and Form of the Traditional

Japanese Family . . . . . . . . . . . . 18

Characteristics of the Traditional

Japanese Family . . . . . . . . . . . . . 23

Strengths and Weaknesses of the 44

III. THE CHANGING JAPANESE FAMILY . . . . . . . . . . . . . 46

Early Influences . . . . . . . . . . . . 47

Influences of Confucian Thought and Buddhist Belief ............... 52

Influences of the Tokugawa Era (1603-1868) . . . . . 57

Influences of the Meiji Restoration... . . . . 62

Recent Influences... . . ............ 68

Remnants of the Traditional Family Today . . . . . . 74

IV. SURVEYING THE ADVENTIST FAMILY IN JAPAN • • . . . . . • . 82

Research Design . . . . . . . . . . . . . 82

Instrumentation... . . . . . . . . . . . . 83 
Chapter

IV. (Continued)

Data Collection. . . . . . . . . . . . 85

Limitations . . . . . . . . . . . . . . . 90

Treatment of Data... . . . . . . . . . . 93

Summary . . . . . . . . . . . . . . 93

V. FAMILY BIOGRAPHICAL DATA . . . . . . . . . . . 95

Age of Respondents . . . . . . . . . . . . 95

Length of Marriage . . . . . . . . . . . . . 97

Age Differential of Spouses . . . . . . . . . . 98

Marriage Status . . . . . . . . . . . 103

Method of Choosing Marriage Partner . . . . . . . 104

Miai and Renai Form of Marriage Arrangement . . . . . 106

Degree of Acquaintance Before Marriage . . . . . . 108

Education Level . . . . . . . . . . . . . . 108

Employment of Major Wage Earner . . . . . . . . . 111

Income of the Adventist Family . . . . . . . . . . 113

Home Ownership and Housing Status . . . . . . . . 116

VI. CHILDREN IN THE FAMILY . . . . . . . . . . . . 119

Number of Children in the Adventist Family . . . . . 119

Discipline and Training of Children
in the Home . . . . . . . . . . . . . . . . 120

Christian Education and the Adventist Family . . . . 123

Parental Ambitions for Eldest Son . . . . . . . . 130

Adventist Parents' Influence on
Their Children's Conversion . . . . . . . . . . . . 134

Importance of Marriage of Children
to Church Members . . . . . . . . . . . . 135

Parental Opinion as to How Marriage

Partners Should be Chosen . . . . . . . . . . 141

Attendance of Children from Adventist

Homes at Religious Services . . . . . . . . . 144

VII. RELIGION IN THE FAMILY . . . . . . . . . . . . . 148

Religious Background of the Parental Home . . . . . 148

Family Worship in the Adventist Family . . . . . . . 151

Adventist Published Periodicals Read

Adventist Families and the

Writings of E. G. White . . . . . . . . . 158

Degree of Active Involvement in
Local Church Leadership . . . . . . . . . . . 159 
Chapter

VII. (Continued)

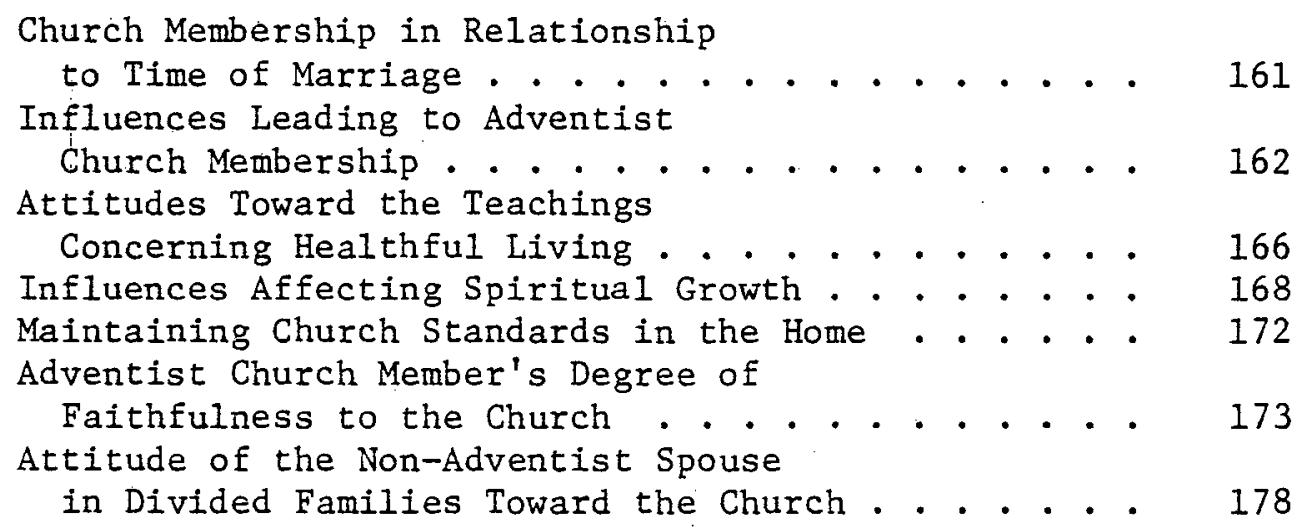

VIII. STABILITY AND HAPPINESS OF THE FAMILY . . . . . . . . 188

Marriage Partners' Evaluation of

Success and Happiness of their Own Marriage . . . 189

Increase or Decrease of Happiness in the Home . . . . 208

Potential Problem Areas in Adventist Homes . . . . 209

Divorce as Viewed by Adventist Spouses . . . . . . . 213

Satisfaction of Adventist Spouses with

Sexual Relations in their Marriage . . . . . . . 215

Degree of Understanding and Communication

Between Spouses . . . . . . . . . . . . . . 216

Marital Quarreling and Conflict

Among Adventist Couples... . . . . . . . . 217

Degree of Participation in Mutual

Activities and Hobbies ............ 221

IX. DYNAMICS IN THE FAMILY . . . . . . . . . . . . 223

Position of Authority in Adventist Families . . . . 223

Control of Finances in the Family . . . . . . . . . . 228

Attitudes of Adventist Spouses Toward the

Wife Working Outside the Home . . . . . . . . 229

Extent of Acquaintance and Intimate

Friendship with Neighbors . . . . . . . . . 234

X. FAMILY-RELATED VIEWS OF UNMARRIED ADVENTIST YOUTH . . . 236

Selected Biographical Information

Concerning Single Adventists . . . . . . . . . 237

Happiness of the Parental Home as

Viewed by Single Adventist Youth . . . . . . . 240 
TABLE OF CONTENTS (Continued)

Chapter

X. (Continued)

Final Authority in the Parental Home as Viewed by Single Adventist Youth . . . . . . . . .

Influences Affecting the Spiritual Growth as Reported by Single Adventist Youth . . . . . . .

Attitudes toward Marriage Arrangements and

Choosing of the Marriage Partner as Viewed by Single Adventist Youth . . . . . . . . . . .

Attitudes of Single Youth Toward the Wife Working Outside the Home . . . . . . . . .

Assisting the Youth of the Church to

Establish Christian Homes as Viewed by

Single Adventist Youth . . . . . . . . . . .

XI. THE ROLE OF THE ADVENTIST CLERGY IN FAMILY MINISTRY . •

Selected Information Concerning Adventist

Ministers in Japan . . . . . . . . . . . . . .

Specialized Training and Education for Family Ministry . . . . . . . . . . . . . . .

Extent of Sermons and Talks Concerning the Family by the Adventist Clergy . . . . . . . .

Family Related Counseling by Adventist Ministers.. . . . . . . . . . . . .

Major Problem Areas in the Family as Viewed by Adventist Ministers . . . . . . . . .

Seeking the Understanding and Approval of

Close Family Members Before Baptizing

a Candidate . . . . . . . . . . . . . . . .

Expression of Interest on the Part of Adventist Ministers for Further Training for Family Ministry . . . . . . . .

XII. RESPONDENTS' SUGGESTIONS FOR STRENGTHENING THE

ADVENTIST FAMILY FOR FAMILY EVANGELISM . . . . . . . 284

XIII. SUMMARY, INSIGHTS, AND RECOMMENDATIONS . . . . . . . 295

Summary of Findings Concerning the Adventist Family in Japan . . . . . . . . . . 296

Insights and Convictions Related to the Family . . . 301

Recommendations Concerning Family Ministry . . . . 305 


\section{TABLE OF CONTENTS (Continued)}

APPENDICES

A. Seventh-day Adventist Family Survey . . . . . . . . . 314

B. Unmarried Seventh-day Adventist.Youth Survey . . . . . 332

C. Seventh-day Adventist Ministers' Survey ... . . . . . . 344

D. Church Membership Faithfulness Survey . . . . . . . 353

BIBLIOGRAPHY . . . • . . . . . . . . . . . . 356

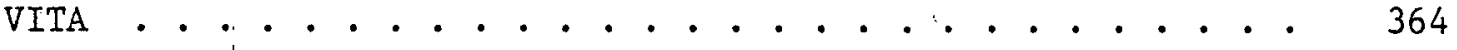




\section{LIST OF TABLES}

1. Seventh-day Adventist Family Survey Response . . . . . . 87

2. Unmarried Young People's Survey Response . . . . . . . . . 89

3. Age Categories of Adventist Spouses . . . . . . . . . . 96

4. Length of Present Marriage . . . . . . . . . . . . . 97

5. Age Differential of Husbands and Wives . . . . . . . . . 98

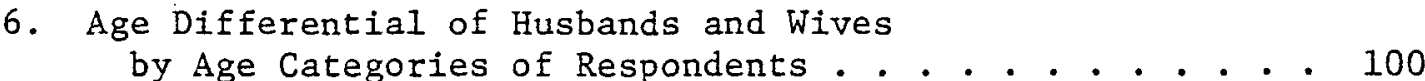

7. Correlation Between the Age Differential of Husbands and Wives and the Methods of Choosing Marriage Partners ... . . . . . . . 102

8. Marriage Status . . . . . . . . . . . . 103

9. Method of Choosing Marriage Partner . . . . . . . . 105

10. Correlation Between the Method of Choosing

Marriage Partners and the Age of the Respondent . . . 106

11. Form of Marriage Arrangements . . . . . . . . . . . 107

12. Degree of Acquaintance Before Marriage . . . . . . . . . 109

13. Level of Education . . . . . . . . . . . . . . . . . 109

14. Education Level of Japanese Population Over 15 Years of Age - 1970 . . . . . . . . . . . . . . 111

15. Employment of Major Wage Earner of Family . . . . . . . . 112

16. Yearly Family Income . . . . . . . . . . . . . . . . 114

17. Correlation Between the Yearly Family Income and the Employment Category . . . . . . . . . . . 115

18. Housing Status . . . . . . . . . . . . . . . . 117

19. A Correlation Between the Housing Status and the Employment Category .... . . . . . . . 118

20. Number of Children in the Family . . . . . . . . . . . 120

21. Correlation Between the Number of Children and the Employment Category . . . . . . . . . . . . 121

22. Types of Discipline and Training of Children . . . . . . . 122

23. Children Sent to Adventist Schools . . . . . . . . . . . . 124

24. Correlation Between Children Sent to Adventist Schools and the Employment Categories of Parents . . . . 124

25. Correlation Between Children Sent to Adventist Schools and the Yearly Family Income... . . . . . 125

26. Correlation Between Children Sent to Adventist Schools and the Adventist Background of Parents . . . . 126

27. Correlation Between Children Sent to Adventist Schools and the Education Level of Parents . . . . . . . 126

28. Correlation Between Children Sent to Adventist Schools and the Number of Spirit of Prophecy Books in Home . . . . . . . . . . . . . . . . . . . 128

29. Correlation Between Children Sent to Adventist Schools and the Non-Adventist Spouse's Attitudes Toward Church 
30. Reasons for Not Sending Children to Adventist Schools . . . . . . . . . . . . . . . . .

31. Parents' Preference for Eldest Son's Future Life Work . . . . . . . . . . . . . . 131

32. Correlation Between Parents' Perference for Eldest Son's Future Life Work and the Employment Categories of Parents . . . . . . . . . .

33. Parental Opinion as to Their Own Greatest Influence on Their Childrens' Conversion . . . . . . . . 134

34. Parental Opinion as to the Importance of Their Children Marrying an Adventist Church Member . . . . 136

35. Correlation Between Parental Opinion as to the Importance of Their Children Marrying an Adventist and the Employment Categories of Parents... . . . .

36. Correlation Between Parental Opinion as to the Importance of Their Children Marrying an Adventist and the Category of Marriage Partner . . . . .

37. Correlation Between Parental Opinion as to the Importance of Their Children Marrying an Adventist and the Adventist Background of Parents . . .

38. Correlation Between Parental Opinion as to the Importance of Their Children Marrying an Adventist and the Regularity of Family Worship . . . . .

39. Correlation Between Parental Opinion as to the Importance of Their Children Marrying an Adventist and the Number of Spirit of Prophecy Books in Home . . . . . . . . . . . . . . . . . . . .

40. Parental Opinion as to Method of Choosing Children's Marriage Partner . . . . . . . . . .

41. Attendance at Services of the Church by Children of Adventist Families . . . . . . . . . . 146

42. Religious Background of Respondents' Parental Home . . . . 149

43. Adventist Background of Parental Home . . . . . . . . . 150

44. Regularity of Family Worship . . . . . . . . . . . . . . 151

45. Correlation Between Regularity of Family Worship and Employment Categories of Major Wage Earner ..................

46. Correlation Between Regularity of Family Worship and the Adventist Background of Parental Home

47. Leadership in Family Worship . . . . . . . . . . . . . 155

48. Adventist Periodicals Read Regularly . . . . . . . . . . . 156

49. Correlation Between Adventist Periodicals Read Regularly and the Employment Category of Major Wage Earner ... . . . . . . . . . . 157

50. Volumes of E. G. White Writings in the Home . . . . . . 159

51. Church Offices Held During the Past Two Years . . . . . 160

52. Correlation Between Involvement in Church Leadership During the Past Two Years and Adventist Background . . . . . . . . . . . . . 
53. Time of Becoming an Adventist Church Member

in Relation to Time of Entering Marriage . . . . . . .

161

54. Strongest Influence in Becoming an Adventist Member . . . . . . . . . . . . . . . .

55. Correlation Between Strongest Influence

Leading to an Adventist Church Membership

and Adventist Background . . . . . . . . . . . . . . . .

56. Attitude Toward the Adventist Health Message . . . . . 167

57. Correlation Between Attitude Toward the

Adventist Health Message and Adventist

Background . . . . . . . . . . . . . . . . . . . .

58. Most Helpful Influences in the Development

of Spiritual Life . . . . . . . . . . . . 171

59. Problem Areas in Home Concerning Maintenance of Standards . . . . . . . . . . . . .

60. Degree of Faithfulness of Church Members According to Sex as Perceived by Adventist Pastors . . . . . . . . . . . . . . . . . .

61. Degree of Faithfulness of Church Members as Perceived by Adventist Pastors When Comparing Spouses of United Families with Others . . . . . . . . . . . . . . 179

62. Non-Adventist Spouse's Attitude Toward the Church . . . . 182

63. Correlation Between Non-Adventist Spouse's Attitude Toward the Church and Evaluation of Success and Happiness of Divided Families . . . . .

64. Correlation Between Non-Adventist Spouse's Attitude Toward the Church and Degree of Quarreling Between Marriage Partners of Divided Families . . . . . . . . . . .

65. Correlation Between Non-Adventist Spouse's Attitude Toward the Church and Degree of Sexual Satisfaction in Divided Families . . . . . .

66. Correlation Between Non-Adventist Spouse's Attitude Toward the Church and Mutual Understanding and Level of Communication in Divided Families . . . . . . . . . . . . . . . . .

67. Personal Evaluation of Success and Happiness of Own Marriage . . . . . . . . . . . . . . . . .

68. Correlation Between Evaluation of Success and Happiness of Marriage and Sex of Marriage Partner . . .

69. Correlation Between Personal Evaluation of Success and Happiness of Marriage and Age of Marriage Partners . . . . . . . . . . . . . .

70. Correlation Between Evaluation of Success and Happiness of Marriage and Length of Marriage

71. Correlation Between Evaluation of Success and Happiness of Marriage and Age Differentials of Marriage Partners . . . . . . . . . . . . . .

72. Correlation Between Evaluation of Success and Happiness of Marriage and Method of Choosing Marriage Partners 
72. Correlation Between Evaluation of Success and Happiness of Marriage and Method of Choosing Marriage Partners . . . . . . . . . .

73. Correlation Between Evaluation of Success and Happiness of Marriage and Degree of Acquaintance Before Marriage . . . . . . . .

74. Correlation Between Evaluation of Success and Happiness of Marriage and Employment Categories of Marriage Partners . . . . . . . . . . .

75. Correlation Between Evaluatuion of Success and Happiness of Marriage and Yearly Family Income . . . . . . . . . . . . . . . . . . . . .

76. Correlation Between Evaluation of Success and Happiness of Marriage and Level of Education of Marriage Partners . . . . . . .

77. Correlation Between Evaluation of Success and Happiness of Marriage and Adventist Background of Marriage Partners . . . . . . . . . . . .

78. Correlation Between Evaluation of Success and Happiness of Marriage and Regularity of Family Worship ... . . . . . . . . . . . . . .

79. Correlation Between Evaluation of Success and Happiness of Marriage and Regularity in Praying Together . . . . . . . . . . . . . . . . . .

80. Correlation Between Evaluation of Success and Happiness of Marriage and Time of Becoming a Church Member in Relation to Time of Entering Marriage . . . . . . . . . . . .

81. Progression of Marital Happiness as Perceived by Marriage Partners . . . . . . . . . . 208

82. Problem Areas in Marriage as Perceived by Adventist Spouses . . . . . . . . . . . . . . .

83. Correlation Between Problem Areas in Marriage as Perceived by Adventist Spouses and Length of Marriage . . . . . . . . . . . . . . . . . .

84. Contemplation of Divorce as Solution. to Marriage Problems . . . . . . . . . . . . . . .

85. Correlation Between the Contemplation of Divorce as Solution to Marriage Problems and Sex of Respondent . . . . . . . . . . . . . . . .

86. Satisfaction with Sexual Relations in Marriage . . . . . . 216

87. Mutual Understanding and Level of Communication Between Spouses . . . . . . . . . . . . 218

88. Degree of Quarreling Between Marriage Partners . . . . . . 219

89. Correlation Between Degree of Quarreling

Between Marriage Partners and Age of Spouses . . . . . 220

90. Mutual Hobby Enjoyed by Marriage Partners .. . . . . . . 222

91. Final Authority of Homes in Which Adventist Spouses were Raised 
92. Final Authority in Adventist Homes Today . . . . . . . 226

93. Correlation Between Final Autority in Adventist Homes Today and Authority in Homes in Which They were Raised . . . . . . . . . 227

94. Control of Family Finances . . . . . . . . . . . . . 230

95. Correlation Between Control of Family Finances and Age of Marriage Partners . . . . . . . 231

96. Attitude Toward Wife Working Outside the Home . . . . . 232

97. Correlation Between Attitude Toward Wife Working Outside the Home and Age of Adventist Spouse . . . . . . . . . . . . . . 233

98. Extent of Friendship of Adventist Families with Neighbors . . . . . . . . . . . . 235

99. Selected Characteristics of Single Adventist Youth . . . . 238

100. Single Adventist Youth's Evaluation of the Happiness of the Home in Which They were Raised . . . . . . . . . . . . . . . 242

101." Correlation Between Single Adventist Youth's Evaluation of the Happiness of the Home in Which They were Raised and Age of Respondents . . . . . 242

102. Correlation Between Single Adventist Youth's Evaluation of the Happiness of the Home in Which They were Raised and the Religious Background of Their Parental Home . . . . . . . . . . 244

103. Single Adventist Youth's Evaluation as to Final Authority in Parental Home . . . . . . . .

104. Single Adventist Youth's Opinion as to the Ideal Division of Authority Between Husband and Wife... . . . . . . . . . . . . . .

105. Single Adventist Youth's Opinion as to the Most Helpful Influences on Development of Spiritual Life... . . . . . . . . . . . . . .

106. Single Youth's Opinion as to Method of Choosing Marriage Partner .. . . . . . . . . . .

107. Single Adventist Youth's Opinion as to the Best Form of Marriage Arrangement . . . . . . . . . .

108. Single Adventist Youth's Opinions as to the Importance of Marrying a Seventh-day Adventist Church Member .. . . . . . . . . . .

109. Correlation Between Single Adventist Youth's Opinions as to the Importance of Marrying a Seventh-day Adventist Church Member and Age of the Young Person $\cdot \dot{0} \cdot \dot{\text { Adventist Youth's }}$

110. Correlation Between Single Adventist Youth's
Opinions as to the Importance of Marrying a Seventh-day Adventist Church Member and Extent of Education in Adventist Schools . . . . . . . . . . .

111. Single Adventist Youth's Attitude Toward Marriage Plans if Parents Strongly Opposed Plans 
112. Single Adventist Youth's Opinions as to the Probable Results of Marriage to a Non-Member . . . . . . . . . . . . . . . . . . .

113. Single Adventist Youth's Opinions Regarding Wife Working Outside the Home . . . . . . . .

114. Single Adventist Youth's Opinions as to How Much the Church is Doing to Help its Young People Find Adventist Mates

115. Correlation Between Single Adventist Youth's Opinion as to How Much the Church is Doing to Help its Young People Find Adventist Mates and Age of the Youth . . . . . . . . .

116. Response of Single Adventist Youth to Suggestions as to How the Church can Help its Young People Find Adventist Mates

117. Correlation Between Response of Single Adventist Youth to Suggestions as to How the Church can Help its Young People Find Adventist Mates and Age of Youth . . . . . . . . . .

118. Selected Characteristics of Seventh-day Adventist Ministers . . . . . . . . . . . . . .

119. Family-Ministry-Related Training of Seventh-day Adventist Ministers . . . . . . . . . .

120. Correlation Between the Amount of Reading in the Areas of Marriage Counseling and Family Relationships During the Past Twelve Months and the Age of the Minister ... . . . . . . . . .

121. Sermons and Talks Presented on Family-Related Topics During the Past Twelve Months by Seventh-day Adventist Ministers . . . . . . . . . .

122. Degree of Pre-Marriage Counseling of Couples by Seventh-day Adventist Ordained Ministers . . . . . . .

123. Degree of Marriage Counseling by Seventh-day Adventist Ministers . . . . . . . . . .

124. Degree of Child-Related Counseling by Seventh-day Adventist Ministers . . . . . . . . . .

125. Major Problem Areas of Adventist Families as Seen by Seventh-day Adventist Ministers

126. The Extent to Which Seventh-day Adventist Ministers Sought the Understanding and Approval of Close Relatives or Spouse of the Candidate Before Baptism . . . . . . . . . . . . . .

127. Desire Expressed by Seventh-day Adventist Ministers for Further Training in Family Ministry 


\section{LIST OF FIGURES}

1. Age differential of husbands and wives by age categories... . . . . . . . . . . . 101

2. Attendance at services of the church by the children of Adventist families. . . . . . . . . 147

3. Sex distribution of Adventist church members . . . . . . 174

4. Degree of faithfulness of church members as perceived by Adventist pastors . . . . . . . . . . . 174

5. Degree of faithfulness of church members according to sex as perceived by Adventist pastors . . • 177

6. Degree of faithfulness of church members as perceived by Adventist pastors when comparing spouses of united families with others . . . . . . . . . 180 


\section{ACKNOWLEDGEMENTS}

The writer desires to express gratitude and appreciation to the many whose help and cooperation have contributed to the completion of this research project.

To a loving Heavenly Father the writer is profoundly grateful for the privilege of laboring for so many years in Japan and for His sustaining help without which this project could never have been completed.

Sincere appreciation is expressed to the Far Eastern Division and Japan Union Mission of Seventh-day Adventists and to Saniku Gakuin College for providing financial support and for arranging a s.tudy leave in which to complete the project.

of the many individuals who have made valuable contributions to this study, two are outstanding: Dr. Rudolf Klimes, chairman of the writer's doctoral program committee, who gave unstintingly of his time, counsel, and advice; and Dr. Tsutomu Hosoi, professor and head of the computer center of Tsuda Juku College in Tokyo, who freely gave his advice and his time and expertise in computer processing.

Others who should be mentioned are Dr. Arnold Kurtz, chairman of the Doctor of Ministry program of Andrews University, for his interest and encouragement in the over-all program; M. Hirota, editor of the Japanese Signs of the Times, who shares a deep interest 
in the subject of this research project, for editing the Japanese questionnaires; Dr. Shigenobu Arakaki and Dr. Lowell Hagele, colleagues at Saniku Gakuin College, for their friendship, encouragement, and help; Kazuyuki Munetomo, for help in researching Japanese literature and translating the questionnaires into Japanese; and Miss T. Odahara, for faithful assistance with secretarial detail. Finally, the writer wishes to express gratitude to his wife Norma and his daughter Bonnie for their love and patience, and for assisting with typing, editorial detail, and helpful criticism. Without the support and help of these and many others, this research project could not have been completed. 


\section{CHAPTER I}

\section{INTRODUCTION}

Japanese Christianity today cannot escape the fact that after 115 years in the modern era of missionary endeavors, it is still a small minority of the nation. Recent statistics ${ }^{1}$ indicate that at the end of 1975 there were 794,125 Protestant and 388,556 Catholic Christians in Japan, or a total of 1,182,681 Christians in the nation with a total population of nearly $112,000,000$. This means that only slightly more than 1 percent of the population is Christian. And of this small percentage of Christians, Seventh-day Adventists are represented by only a little over 8,000 members, or about one out of 14,000 of the population.

Christianity was first introduced into Japan by the Jesuit missionary, Francis Xavier, who arrived in 1549. However, that colorful saga of the attempt to bring Christianity to Japan ended about one hundred years later under the persecution of the Tokugawa Shogunate. The interest in this early period of Christian missions was sparked anew by the best-selling historical novel, Chimoku (translated as Silence in its English edition). This book, written in 1968 by Shusaku Endo, describes the persecution and martyrdom in those days and the apostasy of the last two Christian priests.

\footnotetext{
$1_{\text {Kirisutokyo Nenkan }}$ (Tokyo: Kirisuto Shimbunsha, 1976), p. 472 .
} 
In the preface to the English edition, William Johnston, the translator, makes the following significant comment:

The interest this novel evoked in Japan was less historical than contemporary. The two foreign apostates were immediately taken as symbols of a Christianity which failed in Japan because it is so stubbornly Western. "Father, you were not defeated by me," says the victorious Inoue. "You were defeated by this swamp of Japan."1

To many concerned Christian missionaries today, as well as to those Japanese who have accepted Christianity, the "swamp of Japan" is an ever present and awesome challenge. And this task of developing within the soil of Japan a strongly-rooted indigenous expression of Christianity is complicated not only by the inhospitable "swamp" which faced the earlier missionaries, but also by the "swamp complex," which dominates the thinking of many Christian workers in Japan today.

The evaluation of William Johnston, "that Christianity must adapt itself radically if it is to take root in the 'swamp' of Japan," 2 should be taken with the utmost seriousness by the church today. If his analysis is correct, one must assume that the Christian church has, to a great extent, failed to adapt itself radically to Japanese society and culture, for it is doubtful if one can say that Christianity today has, with any degree of reality, taken root. A genuinely indigenous Christian church is still a goal to be attained. Christianity is now well within the second century of its renewed attempt to establish its roots in Japan, and the Advent Message

${ }^{1}$ Shusaku Endo, Silence (Tokyo: Charles E. Tuttle Co., 1969), back cover.

$$
{ }^{2} \text { Ibid., p. } 1 .
$$


has now passed the three-quarter century mark in its missionary endeavors. Perhaps it is time to look again at the task of the church and to re-examine its missionary methods and premises. Christians are convinced that the cause for slow growth of the church does not lie in the content of the Christian faith as such. Assuming that this is so, the fault must then lie in the manner in which the faith is propagated or in the lack of adaptability of the Christian message or messengers to the culture and society of Japan.

\section{The Problem}

A major area that has largely been neglected by the church in its attempt to bring the gospel message to Japan is the family. Among non-Christians and Christians alike, the family is the most important social unit. According to a public poll conducted in 1968 by the Yomiuri newspaper using a national sample of 10,000 persons between 15 and 70 years of age, the chief concern of the Japanese was "my family." 1 This would indicate that if Christianity is to "adapt itself radically" to Japanese culture in order to take deep root in the soil of Japan, it must gain a deeper understanding of and appreciation for the family.

Human beings are born into family groups, are nurtured by close association with family members, and spend most of their lives within a network of family relationships. The family is thus the most basic of all social institutions and its welfare

\footnotetext{
${ }^{1}$ Takeshi Ishida, Japanese Society (New York: Random House, 1971), p. 98.
} 
should be the subject of deep concern and careful study by Christians who are interested in evangelism.

Social scientists, sensing the strategic significance of the family's "mediating function in the larger society," 1 which links the individual to the larger social structure, have long recognized the importance of studying the family. Through the family, a person is made aware of who he is and what his relationships to society at large should be. Individuals develop both conscious and unconscious sets of life-long values through a long period of childhood training. As Clifford Kirkpatrick states, "The influence of the family upon larger social groups is very great. . . It is generally agreed that the family trains for social participation. We could accept Cooley's dictum that the family as a primary group is a nursery of human nature." 2

Unfortunately, Christians in Japan, although recognizing the importance of the family, have tragically failed to understand fully the nature of the Japanese family or to exploit its potential as a tool for evangelism. Dr. Takaaki Aikawa, formerly president of Kanto Gakuin, a university in Yokohama, stated that "Christianity could have had far greater influence [in Japan] had it been introduced with a deep concern for the family, according to the Oriental tradition." 3

I William J. Goode, The Family (Englewood Cliffs, New Jersey: Prentice Hall, Inc., 1964), p. 2 .

${ }^{2}$ Clifford Kirkpatrick, The Family as Process and Institution, $2 d$ ed. (New York: The Ronald Press Co., 1963), p. 4.

3 Takaaki Aikawa and Lynn. Leavenworth, The Mind of Japan (Valley Forge, Pa.: The Judson Press, 1967), P. 70. 
He goes on to point out that the newly revitalized Soka Gakkai and Jōdo Shin Buddhist sects have capitalized on the family unit rather than on the individual. "In contrast to this emphasis on the family, Christianity began its introductions with an emphasis upon a European-type of individualism, virtually ignoring the family."1 And what has been the result of this failure on the part of Christianity to develop a family-centered strategy? Dr. Aikawa elaborates:

Christianity has been penalized for its failure to take the homechurch method seriously. . . The mistakes of the early missionaries to Japan and the Japanese pioneer Christians must be corrected. At stake is the serious, balanced appreciation of the cultural integrity of Japan. The early leaders assumed that the material superiority of the West was a total cultural superiority. They thought that they could transplant the sturdy Western plants into the Eastern soil without concern for their power to grow in that soil.2

Charles H. Germany, in his book The Response of the Church in Changing Japan, states that

a pressing issue for the entire Christian community as it moves into the second half of the 20 th century is the definition of the proper and necessary character of a truly indigenous church. Indigenization has two dimensions. One is the question of how to sow the seed of the gospel in the soil of Japan's culture. The other is how to cultivate and nurture the native soil itself so that it will receive the seed and bear good fruit. 3

Perhaps another dimension of the problem is how to radically adapt the message and the messengers, so they will be acceptable to people of a non-Western culture.
$1_{\text {Ibid. }}$
${ }^{2}$ Ibid., p. 71 .
${ }^{3}$ Charles H. Germany, The Response of the Church in Changing Japan (New York: Friendship Press, 1967), p. 7. 
Since the family is so solidly embedded in the history and culture of Japan and is such an important part of society, it is of primary importance that the Christian church develop a deeper understanding of it. For as has been noted, Takaaki Aikawa suggests, the influence of the church's mission will be limited until a "deep concern for the family according to the Oriental tradition" accompanies it. At present, there exists no study that adequately describes or aids in the deeper understanding of the Seventh-day Adventist family in Japan.

\section{Importance of the Family in}

the Divine Plan

From the beginning of Genesis, the old Testament regards the human family as a divinely sanctioned institution and the basic unit of society. The religion of the old Testament, from the age of the patriarchs on, has been primarily family-centered, as is evidenced by the importance of the Eden home, the centrality of the family altar, the various sacred meals which the family partook of jointly, and the required attendance of certain yearly religious festivals. The New Testament also places great stress on the centrality of the family in God's plan of saving men. The first Gentile conversions to the Church mentioned by name were the members of Cornelius' household (Acts 11:7, 24). At Philippi, Paul led the household of Lydia and of the jailor to faith in Christ (Acts 16:2533). The families of Crispus (Acts 18:8) and Stephanus (1 Cor $1: 14-16)$ also are illustrations of the importance of the family in the spread of the gospel in the early New Testament church. 
Ellen G. White, whose writings hold an important and unique place in the Seventh-day Adventist church, placed great stress on the importance of the family, not only for its own sake but also as an instrument through which God desires to work for the salvation of others. The following are samples of this abundant counsel and instruction:

The greatest evidence of the power of Christianity that can be presented to the world is a well-ordered, well-disciplined family. This will recommend the truth as nothing else can, for it is a living witness of its practical power upon the heart. 1

The mission of the home extends beyond its own members. The Christian home is to be an object-lesson, illustrating the excellence of the true principles of life. Such an illustration will be a power for good in the world. Far more powerful than any sermon that can be preached is the influence of a true home upon human hearts and lives. As the youth go out from such a home, the lessons they have learned are imparted. Nobler principles of life are introduced into other households, and an uplifting influence works in the community. 2

Our work for Christ is to begin with the family in the home. The education of the youth should be of a different order from that which has been given in the past. Their welfare demands far more labor than has been given them. There is no missionary field more important than this. By precept and example parents are to teach their children to labor for the unconverted. 3

The restoration and uplifting of humanity begins in the home. The work of parents underlies every other. Society is composed of families, and is what the heads of families make it. Out of the heart are "the issues of life:" and the heart of the community, of the church, and of the nation, is the household. The well-being of society, the success of the church, the prosperity of the nation, depend upon home influences. 4

${ }^{1}$ Ellen G. White, Adventist Home (Nashville, Tenn.: Southern Publishing Association, 1952), p. 32 .

2 Ellen G. White, Ministry of Healing (Mountain View, Calif.: Pacific Press Publishing Association, 1943), p. 352.

3 Ellen $G$. White, Testimonies for the Church, 9 vols. (Mountain View, Calif.: Pacific Press Publishing Association, 1948), 6:429. 4 White, Ministry of Healing, p. 349. 
The first work of Christians is to be united in the family. Then the work is to be extended to their neighbors nigh and afar off. . . .1

Seventh-day Adventist parents should more carefully realize their responsibilities as character builders. God places before them the privilege of strengthening His cause through the consecration and labors of their children. 2

The circle of family and neighborhood duties is the very first field of effort for those who would work for the uplifting of their fellow men. There is no more important field of effort than that committed to the founders and guardians of the home. No work entrusted to human beings involves greater or more farreaching results than does the work of fathers and mothers. 3

(Emphasis supplied)

\section{Purpose of Study}

The purpose of this study is to describe the characteristics and problem areas of the Seventh-day Adventist family in Japan. Answers to the following questions connected with the family will be sought:

1. What biographical data describes the family?

2. What kind of training and education are the children receiving?

3. What are the religious practices and influences of the family?

4. What is the atmosphere and degree of stability of the family?

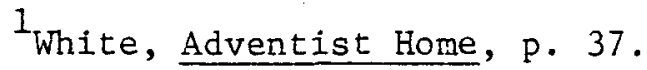

2 E1len G. White, Counsels to Parents and Teachers (Mountain View, Calif.: Pacific Press Publishing Association, 1942); p. 131.

3 White, Ministry of Healing, p. 351. 
5. What dynamics are at work on the family?

6. What are the similarities and differences of divided homes to that of united Seventh-day Adventist families?

7. What are some of the attitudes and problems of Seventhday Adventist single youth regarding Christian marriage and the home?

8. To what extent are church leaders engaged in strengthening the home and in family evangelism?

9. What type and amount of education have church leaders had for family ministry?

\section{Importance of the Study}

A failure to understand in depth the psychology and culture of the Japanese people, especially the distinctive characteristic of Japanese social life that subordinates the desires and decisions of the individual to that of the group, is a contributing factor to the slow growth of the church in Japan. Christianity, largely introduced from the West, has always placed strong emphasis on personal autonomy and individual decision. But when one member is forced to make a decision for God without concern for the wishes of the family group, it has often brought great stress, conflict, and, at times, bitterness into the home. Failure to resolve this conflict before baptism has probably lead to a high attrition rate among members of such torn and divided families. Hopefully, a better understanding of the family will help the Christian church adapt itself to the needs of the family; then instead of the church working against the culture, it will be working in harmony with culture. When the church has a deeper 
understanding of the dynamics working within the family, then it can use the distinctive Japanese characteristic of "groupness" as the basis for an evangelistic approach that will be concerned with bringing family-related groups into church fellowship.

Marriage and the family have come under increasing attack in recent years in not only Western but also in Eastern society. Some critics have even questioned whether the family as it is now known can long survive. A better understanding of the Japanese Seventhday Adventist family in the context of Japanese society and culture could help the church become aware of the pressures that are being brought to bear on the family today. Such an understanding would then become the basis for specific programs that would help to strengthen and enrich the family. Happier, stronger Christian families would then in turn become more effective agents for evangelism and would provide a stronger base for a deeply-rooted indigenous church.

Bill Gothard, director of the Basic Youth Conflict program, when writing on the home, makes the following statement on the importance of building dynamic marriages and stable homes:

Every major spiritual movement in history has been chiefly carried on through dedicated men who have been committed to a very vital message. We believe that the most desperately needed message of our day is how to build dynamic marriages and vital goal-centered family units. I personally believe, "The world has yet to see what God can do through one family that is totally committed to Him."1

Concerning the importance of the study of family evangelism, A. Leonard Tuggey, the overseas secretary for Asia of the Conservative

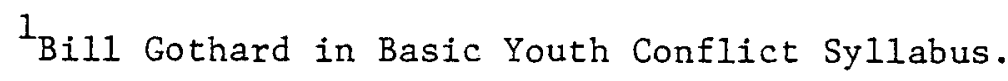


Baptist Foreign Mission Society, recently said: "Many books are being written about the Christian family, but none to my knowledge has devoted itself to the subject of family evangelism. "1 Perhaps it is time for careful study of this vital subject.

If the members of the Seventh-day Adventist church believe that they are now living in the time just preceeding the return of Christ, should they not take seriously the prophecy of Malachi concerning changes in the family in the last days?

Behold, I will send you Elijah the prophet before the coming of the great and dreadful day of the Lord; and He shall turn the heart of the fathers to the children, and the heart of the children to their fathers, lest I come and smite the earth with a curse" (Ma1 4:5, 6).

\section{Outline of the Study}

Since for the purposes of this study the Seventh-day Adventist family can be described meaningfully only in the context of the Japanese family and society as a whole, a preliminary task has been a review of literature that helps identify the basic characteristics of the traditional Japanese family. Historical factors and pressures that have helped to form the structure and characteristics of the family from ancient times to the present have been noted and analyzed in an attempt to understand its inner dynamics.

of special significance is the attempt to trace recent changes in the traditional family system toward a nuclear-type family. Not only has the transforming effect of modern society on the traditional family been noted, but the equally important,

\footnotetext{
${ }^{1}$ A. Leonard Tuggy, "You and Your Household," Theology, News and Notes, Dec. 1974.
} 
lingering effects of the traditional family characteristics and dynamics on today's family, industry, politics, and society in general have been considered also.

The chapters of the research project directly connected with a description of the Seventh-day Adventist family are based on a series of surveys taken in Seventh-day Adventist churches in Japan. Procedural details of these surveys are discussed at greater length in the chapter dealing with the surveys. An attempt has been made to survey all families in Japan in which both husband and wife are Seventh-day Adventist church members. The basic questionnaire sought biographical information, in addition to information concerning children in the family, the stability and happiness of the family, religion in the home, and the dynamics of the family.

This same survey instrument, with some additional questions, was administered to a limited number of Seventh-day Adventist spouses of non-Adventist mates. This was done to determine similarities and differences of these divided homes as compared with united families and to gain insights into the special problems experienced in divided homes.

A second survey of all licensed and credentialed Seventhday Adventist ministers was also conducted. The purpose of this survey was to learn how Adventist pastors and church leaders were attempting to meet the needs of the family and to assess the educational preparation these church leaders have for this type of ministry. 
In an attempt to understand some of the attitudes held by the youth and to comprehend the problems and concerns they face in relation to marriage and the family, a third survey instrument was sent to a limited number of unmarried Seventh-day Adventist young people.

Finally, insights drawn from this study of the Seventh-day Adventist family are discussed. These insights have been synthesized, hopefully, into meaningful and helpful recommendations for strengthening the Adventist family in Japan and for using the family more effectively as a means of evangelistic outreach.

\section{Definition of Terms}

Adventist or SDA. These terms are used as abbreviated forms of Seventh-day Adventist.

United and/or Seventh-day Adventist families. As used in this study, this term refers to families in which both marriage partners are listed on church records as nembers of the church. The expression "united families" has the same meaning, whereas "divided families" is used to mean families in which one of the marriage partners is a baptized member of the church but the other is not.

Church development. This expression as used in this study refers to enriching and strengthening the personal Christian experience of the members of the church, to numerical growth in membership, and to strengthening of the indigenization of the church. 
Advent Message. This term is used to describe the special beliefs and teachings of the last-day gospel message as understood by Seventh-day Adventists. It is centered in Jesus Christ and His work of atonement, mediation, sanctification, and judgment, and His literal soon return to this earth in order to deliver the redeemed and to usher in an era of eternal peace and righteousness. Ellen G. White (1827-1915). Mrs. White is an individual whom Seventh-day Adventists accept as a divinely inspired messenger to the church and to the world. The term, Spirit of Prophecy, as commonly used by Seventh-day Adventists, refers to her writings which are considered divinely inspired messages from God.

Traditional Japanese family. As used in this study, this expression refers to the Japanese family whose characteristics were developed over the centuries, largely during the Tokugawa Era (1603-1868) and which were fixed even further during the Meiji Era (1868-1912) that followed.

Literature Evangelist. This is a term used by Seventh-day Adventists to designate specially trained and authorized salespersons of religious literature. Such salespersons are also called colporteurs.

\section{Delimitations}

A wealth of material in both English and Japanese deals with the characteristics of the Japanese people and the various historical and cultural influences which have made them what they are today. Materials that have been selected for this study are 
those which relate most directly with the formation of the family and characteristics of the family.

Although the stimulation of church growth is among the long range purposes of this study, a review of the church-development literature has not been included. Rather, this study has been limited to a focus on the Japanese Seventh-day Adventist family with its problems and potentials.

The survey instruments were designed to obtain a clear picture of the Japanese Adventist family and have been limited to those factors which were deemed most likely to contribute to strengthening the family and to forming the basis for greater success in family evangelism. For this reason detailed questions concerning financial, sexual, occupational, and other important areas not as closely related to church growth have not been included.

\section{Personal Expectations}

The joy, excitement, and challenge of being born and reared in the Orient and of working with and for peoples of Eastern culture for nearly thirty years has been a source of deep satisfaction and lasting gratitude. And yet the longer and more intimate the contact with Eastern peoples is made, the deeper is the conviction that not until Christians adapt themselves to meet peoples of different cultures on their own ground will the seed of the gospel find "good ground" that will bear an abundant harvest to God's glory. It is the hope of the author of this research project that this study will have increased his own personal understanding of the 
dynamics working within the Japanese family. It is further hoped that this study will be instrumental in helping him adapt more fully to meet the personal and family needs of the Japanese people with whom he comes in contact.

As a result of these primary expectations, the author hopes to gain insights and prospectives as well as information and experience that will help him develop specific and successful programs for family strengthening and enrichment within the Seventhday Adventist Church. It is further hoped that he will be better prepared to lead out in an evangelistic outreach that will bring more united families into church fellowship. 
CHAPTER II

THE TRADITIONAL JAPANESE FAMILY

One cannot hope to understand twentieth century Japan without some understanding of its roots in the past. This is particularly true of the Japanese family. This chapter and the one that follows consist of a review of the literature on the characteristics of the traditional Japanese family and some of the forces which have combined to produce it. Although literature in both English and Japanese has been consulted, a lack of proficiency in reading Japanese has somewhat limited the extent of the review of literature concerning the family in the Japanese language.

All cultures change and social institutions must adapt themselves to these changes. The family is no exception. In Japan, family patterns were relatively stable for such a long period of time that they seemed to be fixed and changeless, but in fact they were not. The foundation for what is commonly known as the traditional Japanese family was largely formed during the feudal period of Japanese history known as the Tokugawa Era (1603-1868) and, with minor changes, this lasted through several centuries. During the Meiji Era (1868-1912) the process of change was unmistakable, yet much of the old family system not only remained but was in fact fixed even more firmly. Since that time, however, the pace of change has greatly accelerated. And in the years since the end of 
World War II especially, breath-taking changes in the family along with major changes in all other areas of life have taken place.

But in spite of all the sudden and dramatic changes, the new age has not blotted out the old Japan. Nor can anyone know what the Japan of tomorrow will be like. However this much is sure, a helpful perspective of the family of Japan today will be based on an awareness of the forces that are molding it now and on an understanding of its past traditions and inner dynamics.

In an attempt to gain a clearer understanding of the traditional Japanese family, a thumb-nail sketch will be drawn of its structural form. A brief description of some of its more prominent characteristics will be given. It will also be necessary to take a look at the traditional Japanese personality, values, and way of thinking as they pertain to the family.

\section{Structure and Form of the Traditional} Japanese Family

The traditional Japanese family has been described by both Japanese and Western scholars. ${ }^{1}$ It has been characterized as a tightly knit, corporate group which had a nuclear family as the core and often extended to include two or more generations of relatives, plus non-blood related members. It was predominantly patriarchal and the family chief or head wielded autocratic authority over the

${ }^{1}$ Isaiah Ben-Dasan, The Japanese and the Jews (New York: John Weatherhill, Inc., 1972); Bernard S. Silberman, ed., Japanese Character and Culture (Tucson, Ariz.: The University of Arizona Press, 1962); Takie Sugiyama Lebra and William P. Lebra, eds., Japanese Culture and Behavior (Honolulu: The University Press of Hawaii, 1974); Pear1 S. Buck, The People of Japan (New York: Simon and Schuster, 1966); Hiroshi Minami, Psychology of the Japanese People (Toronto: University, of Toronto Press, 1971). 
members of his extended family or clan, not for his own personal benefit, but as a symbol and agent of the family, past, present, and future. The relationship was dominance-submissive with the patterns between the family head and the other members of the family that of master-slave.

This "ideal-type" patriarchal family, based upon filial piety and loyalty, is best exemplified by the classical Confucian family of China. However, according to Takeyoshi Kawashima, formerly a professor of law at Tokyo University, this "ideal-type" patriarchal family was modified in Japan by the "feudal family," in which the relationships between clan chief and family members were based on "well-defined, patterned reciprocity, similar to 'rights and duties' defined in the relation of lord and vassal." Professor Kawashima further explains this modification of the Confucianpatriarchal family as follows:

The Chinese patriarchal concept of $\underline{k 0}$, which is an absolute abjuration to serve and honor parents, is modified in the Japanese normative structure by the concept of on, or obligation. That is, one carries out ko to parents only when one receives on from them. This concept of on is a typically "feudal" concept; that is, a concept which stresses reciprocal rights and duties rather than absolute obedience. 1

It appears that during the Tokugawa or feudal period the absolute obedience factor of the Chinese Confucian system tended to be much stronger, especially among the samurai and upper classes; whereas among the common people it was greatly modified by the feudal

$1_{\text {Takeyoshi Kawashima, The Familial Structure of Japanese }}$ Society (Tokyo: Nippon Hyoronsha, 1948). Abstracted and analyzed by Michio Nagai and John W. Bennett in Japanese Character and Culture, edited by Bernard Silberman (Tucson, Arizona: The University of Arizona Press, 1962), p. 105. 
concept of rights and duties based on on. Baron Suyematsu, writing in 1905, states that "In China, filial piety takes precedence, but in Japan loyalty stands first." I

Structurally, the traditional Japanese family was hierarchical, with lineal descent and its attending responsibilities and privileges based on primogeniture and patrilineage. The ie (household) was the fundamental unit of society and its well-being always took precedence over that of the members that made up the household, even that of the autocratic clan head himself. "The ie looms above the individual identities of its members to a degree that is hard to overstress." 2 The hierarchical pattern of the ie organization controlled the relationship of each member to every other family member. A recognized order of obligation and privilege governed all family life and placed each person either above or below every other person. As one writer has stated, "There are no equals within one household." 3 Three basic principles that controlled the hierarchy in the household were that males were superior to females, that elders were superior to juniors, and that those born in the household were superior to those born elsewhere. These principles were deeply ingrained and, in theory at least, no, amount of incompetence or personal incapabilities or defects should be able to alter one's

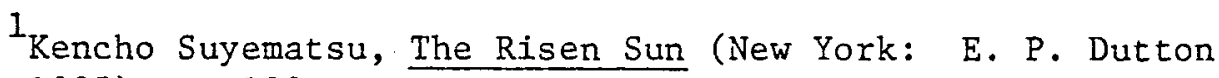
and Co., 1905), p. 193.

${ }^{2}$ Richard K. Beardsley, John W. Ha11, and Robert E. Ward, The Household (Chicago: University of Chicago Press, 1959). Reprinted in Bernard Silberman, ed., Japanese Character and Culture (Tucson, Arizona: The University of Arizona Press, 1962), p. 141.

3 Ibid., p. 156 . 
basic hierarchically established position. These positions were reinforced by household practices, religious doctrine, and legal codes dating back many centuries.

The role of each family member was well defined and well understood, having been learned from earliest infancy. The male head of the household was the final authority within his family, and his rank was understood and respected by all. It was his privilege to be first in the bath and the first to be served at mealtime. In fact, in a former age, the second and subsequent sons, who by the unwritten law of family protocol must wait to be served their rice, not only after the father and oldest son, but also after the very old and the very young, were often called hiyameshi-kui (cold-rice eaters). ${ }^{1}$

In Japanese families, where the line of descent was patrilineal and based on primogeniture, all sons and daughters except the oldest son left the home upon maturity, either to establish their own families or to marry into other families. The oldest son in turn became, on the death of his father, the head of the honke (main or original family), bore the responsibility as the trustee of the family fortunes, its well-being, and good name, and became the recipient of the honor and respect to which his position entitled him.

Seiichi Kitano, Professor of Sociology at Osaka University, made a study of the family genealogical relationships as they

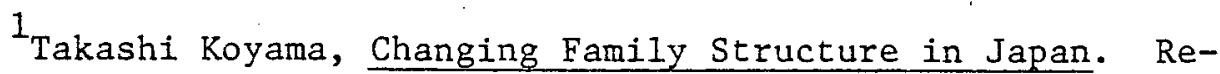
printed in Robert J. Smith and Richard Beardsley, eds., Japanese Culture, Its Development and Characteristics (Chicago: Aldine Publishing Co., 1962), p. 47. 
concerned various structural organizations of clan life especially in rural Japan in past years. "It is well known," he states, "that what is called 'dōzoku' in Japan is composed of the honke (main or original family) and its bunke (branch family). The dozoku is a hierarchical group of bunke, with a honke at the top of the scale, and its members working together in various fields of endeavor. This group prevails over the country under many names."I This dözoku or clan system, made up as it was of one main line family and one or more branch families which accepted its authority, was the back-bone of Japanese society for hundreds of years, and although today it is not as strong as formerly, it still has a significant influence on Japanese society, especially in rural areas. Each of these clan-families was bound together by a common ancestry and by common traditions, and persisted for generations independent of the birth and death of its members. Clan members participated jointly in the worship of the guardian deities of the dozoku and belonged to the same temple. ${ }^{2}$ As one writer has stated it:

The family was a miniature world. The unity and harmony among the family members was the fundamental pre-requisite for the insurance of well-being and security of every individual. Cooperation or mutual concession was therefore the highest principle of family life. 3

ISeiichi Kitano, "Dōzoku and Ie in Japan: The Meaning of Family Genealogical Relationship," in Japanese Culture, Its Development and Characteristics, edited by Robert J. Smith and Richard Beardsley (Chicago: Aldine Publishing Co., 1962), p. 42.

${ }^{2}$ Seiichi Kitano, reprinted in Reuben Hill and Rene Konig, eds., Families in East and West (The Hague, Netherlands: Mouton and Co., 1970), p. 249 . 
This brief sketch of the structure of the traditional Japanese family leads to a description of its characteristics and to the Japanese personality as it pertains to the family.

\section{Characteristics of the Traditional}

\section{Japanese Family}

Group Consciousness

One of the most distinctive characteristics of traditional

Japanese social life was the strong sense of group consciousness, in which the identity of the individual was merged into that of the group. The individual desires were subordinate to the group. Dr. Takaaki Aikawa speaks concerning this loss of individuality under the traditional family system:

Salvation comes only when one dies for the family, according to the traditional Japanese. This is very important because it implies an attitude of fear or even hatred of the ideas of eternal life for the individual. Eternal life in this perspective could mean only eternal responsibility, and eternal responsibility could be only a thing of drugery and dread. As an individual had no center to his being or conscience within himself, he would be lost, not knowing what to do. . . He would not be able to rest until he could find his proper place again in the hierarchy of the family. To an individual, salvation meant the very melting of oneself into the bigger reality, the family. 1 (Emphasis supplied)

Dr. Aikawa goes on to remark that there could be no real meaning for the individual in the family, except as a part of the whole. "In fact, when an English-Japanese dictionary was compiled in 1866, there was no suitable Japanese equivalent for the English word 'individuality.' It was translated as wakatarenu koto, which ${ }^{1}$ Aikawa and Leavenworth, Mind of Japan, p. 29. 
meant 'not to be divided.' The Japanese did not develop the dignity and value of the individual." 1

This characteristic of seeing one's self only in relationship to one's position within a hierarchy, vis-a-vis others in that hierarchy, can also be seen by the twenty different words for the concept of the pronoun "I," or the various forms of the word "you," depending upon status, sex, occupation, and the given occasion. It can also be seen in such language or literary devices as honorific suffixes and special verb endings.

In such a tightly knit social organization with the family as the center, the individual was sacrificed for the good of the family, almost as to a religious body. ${ }^{2}$ The individual was governed in a given situation, not by free choice, but by family or public expectancy. However, when for one reason or another, his obligation, duties, or status relationships were unclear, it was necessary for him to find some type of outlet. "The Japanese have utilized for this purpose, the concept of enryo, loosely translatable as 'hesitance' or 'reserve.' The development of this pattern in Japanese culture is of particular importance." ${ }^{3}$ Enryo often becomes, even today, the escape hatch when an individual's position is unclear. He hesitates, withdraws, and displays reserve until

\section{Ibid.}

2Lafcadio Hearn, Japan, An Attempt at Interpretation (Tokyo: Charles E. Tuttle Co., 1955), p. 79.

${ }^{3}$ John W. Bennett, Herbert Passin, and Robert K. McKnight, In Search of Identity (Minneapolis: The University of Minnesota Press, 1958), pp. 230, 231. 
relationships become clear. This characteristic of traditional Japanese culture and society is also evident at times among Japanese who travel overseas and who find themselves in strange and unfamiliar circumstances. The ambiguity of their feelings in the face of an unfamiliar hierarchy is interpreted as reserve, withdrawal, or noncommitment and can often be traced back to roots in the ancient hierarchical Japanese family.

Another aspect of the Japanese personality, closely related to the selflessness of the individual within the family system has been pointed out in a remarkable book published recently by Dr. Takeo L. Doi, chief psychiatrist at the St. Luke's International Hospital in Tokyo. He points to the tight family system in pre-war Japan as one of the causes that stifled development of a healthy selfhood. ${ }^{1}$ He also sees that the undermining of the old family system with its clearly identifiable and supporting hierarchical relationships without replacing them with sound psychological support is a contributing cause for the moral chaos and the rise in psychological disorders in Japan today. "The Japanese, as a whole," he states, "are still searching for something, something with which they can safely identify, so that they can become whole, independent beings. " 2

$1_{\text {Takeo L. Doi, "Anae: A Key Concept for Understanding }}$ Japanese Personality Structure," reprinted in Japanese Culture, Its Development and Characteristics, edited by Robert J. Smith and Richard Beardsley (Chicago: Aldine Publishing Co., 1962), p. 138.

2 Ibid. 
Submissiveness to Delegated Authority

A second characteristic of the Japanese family, and closely related to that of the merging of the self into the identity of the group, is submissiveness to authority. This quality made the Japanese in prewar times outstanding as law-abiding citizens. From the time of infancy a child was taught not only what his position in the family and in society was, but he was also taught to unquestioningly accept that position and to cooperate loyally with those in positions of power.

In a recent Japanese best-seller which has been translated into English with the title Psychology of the Japanese People, Hiroshi Minami lists submissiveness to authority as one of the primary characteristics of the Japanese. This, he states, was learned through centuries of harsh reality under feudal control. "Hi-ri-hō $\underline{\text { ken-ten }}$ is a traditional phrase in Japan. . . $\underline{\text { Hi }}$ signifies injustice, $\underline{\text { ri }}$ means justice, hō stands for $1 \mathrm{aw}$, ken means authority, and ten denotes the Way of Heaven." During the war, the phrase was used to encourage suicide units and was inscribed as a flag insignia. "The whole phrase implies that injustice is subject to justice, justice to law, law to authority, and authority is subject only to the Way of Heaven. . . "I and thus it is unwise to oppose authority.

This submission to authority, however, was always dependent on recognized authority, position, and hierarchy, whether within the family, business, politics, or society in general.

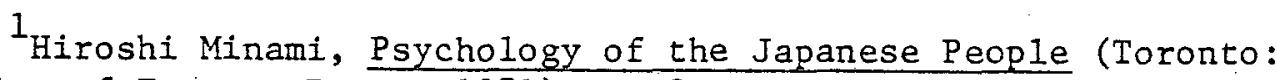
University of Toronto Press, 1971), p. 3 . 
Dominant Position of the Male

Another well-recognized characteristic feature of the traditional family in Japan, which has already been referred to, was the dominance of the male and, conversely, the inferiority and submissiveness of the female. The role of the female was inherently inferior to men. The woman was trained from early childhood to subordinate her desires to that of the male authority in the family, to bear and raise heirs for the ie, and to serve the family. "Indulgence has never been a marked characteristic of the upbringing of daughters in the Japanese family . . and part of their education (had been) not only to repress, but not even. to become conscious of potentially disruptive personal desires." 1

Kennosuke Sato, writing in 1934 before the changes which in recent decades have largely emancipated women from their inferior position, spoke of a woman's rank in relation to man's as that "of an inferior to a superior; of a child to its parents; of a servant to her master. . . Whatever her life, it was inevitably shaped to the accommodation of men." ${ }^{2}$.Her marriage meant her legal adoption by her husband's family and her position was thus doubly inferior, first as a female and second as one born outside the family.

The ideal set before her was to be the perfect servant; well trained, cheerfully willing, inconspicuous and intuitively aware of the wants of those she served. . . Her relation to her husband was also that of a handmaiden. . . . She was

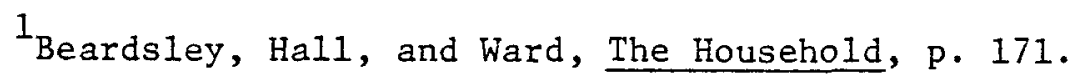

2 Kennosuke Sato, "The Changing Japanese Woman," Contemporary Japan, Sept. 1934, pp. 275-282. (Bound separately--no information given other than above--found in University of Michigan Library, Ann Arbor, Michigan.) 
never her husband's friend and companion, nor even his entertainer in lighter hours. . . . And when inevitably, the husband sought his amusement elsewhere, jealousy was denounced as a cardinal sin. I

However, Kazuo Matsuzawa explains, "such an extremely inferior status of women developed only in the warrior (samurai) class. - Women in the merchant and farmer classes among the commoners enjoyed great power as they became older." ${ }^{2}$ By dutifully accepting her original low status as a new bride, and the oftentimes harsh training by her mother-in-law, she learned how to conform to her new family and to fulfill her obligations as a servant-wife. Her status rose considerably as she bore children, especially if they were male children, for producing and rearing sons to continue the family dynasty was one of her prime duties.

Until she performed this most significant role she could not receive real membership in the family. Yet this did not mean a strong sexual bond between the husband and wife. A strong sexual relationship seemed to be potentially harmful to the corporate unity, and any open show of affection was discouraged. . . The relationship between husband and wife seems to have been a close, quasi mother-child relationship, with the wife taking the mother role in relation to her husband. 3

However, as her son grew to maturity and took his position as the head of the household, she achieved at last the most tranquil period and the highest status of her life. No longer was she thought of as an outsider. Now her son felt strong on (indebtedness) to her for her self-sacrificing service, and she could exert a great

$1_{\text {Ibid. }}$

2 Kazuko Matsuzawa, "Japanese Social Structure and the Status of Women," The Japan Christian Quarterly, Spring 1974, p. 73.

${ }^{3}$ Ibid. 
deal of authority, not only over her son, but over other members of the household as well.

Polygamy tended also to be associated with the patriarchaltype family. Although polygamy was not often a part of the traditional Japanese family, yet common-law marriage has long been an accepted arrangement. Also, for those who could afford it, the keeping of a mekake (mistress) is still not uncommon. "The double standard of sex morality tends, likewise, to be associated with the patriarchal family complex."1 Male privilege in regard to divorce was also evident, it being far more likely that the husband would put away his wife than that the wife divorce her husband.

A related characteristic of Japanese family life should be mentioned. Self-restraint and modesty was always manifested in dealing with one's personal and family possessions, as well as with people. Baron Kancho Suyematsu writing for Western readers nearly seventy years ago noticed the striking difference between the way Japanese husbands or wives spoke of family members and the way Western husbands or wives spoke.

In the west it is not rare for a mother to praise her daughter before others, or for a man or wife to do the same for his or her life partner. It is, no doubt, an outcome of the extraordinary growth of individualism, but the matter is looked upon from a different point of view in Japan. There, we regard our near relatives as though they were a part of ourselves when we speak of them with other people: hence, foreigners would be surprised when they hear that we have such expressions as "my stupid father," "my rustic wife," or "my foolish son," but with us they sound no more strange than when here one calls oneself your humble servant. 2

$1_{\text {Lowell J. Carr, Introductory Sociology (New York: Charles }}$ Scribner's Son, 1933), pp. 80, 81 .

2 Suyematsu, Risen Sun, p. 140. 
It is not that these expressions show any hostile feelings, but that these close relatives are thought of as part of oneself and it would not be good taste to praise oneself. The same is true in speaking of one's home, one's property, some cherished possession, or of a meal served to a guest. Although this characteristic may not be as marked today as when Baron Suyematsu lived, it is still not as easy for a Japanese man as for a Westerner to praise his wife verbally or to express feelings of pride or gratitude. In Japanese culture, self-restraint and modesty often mask one's true feelings.

\section{Marriage Arranged for Family's Benefit,} not by Personal Preference

A fourth characteristic of the traditional family was the way it looked upon marriage. Marriage was primarily looked upon from the viewpoint of and for the advantage of the family. Only secondary consideration was given to the wishes and desires of the young people themselves. Marriage meant the joining of one ie (house) to another rather than joining of two people deeply in 1ove. For this reason it was only natural that marriage arrangements were settled by the families involved, rather than by what Western society would call the concerned parties.

A Japanese author writing in the latter part of the nineteenth century stated that "There is no greater offense to parents, and disgrace to society, than marrying without the parents' consent. "1 Thus,

IDaigoro Goh (Chancellor of the Imperial Japanese ConsulateGeneral in London), "Family Relations in Japan," Transactions of the Japan Society, Vo1. 11, 1892-1893. Quoted in Ray E. Baber, Youth Looks at Marriage and the Family (Tokyo: International Christian University, 1958), p. 48. 
arranged marriages were the rule, and completely free marriage in which the young people chose their own marriage partners on a personal basis was virtually unknown. Those who did usually paid a heavy penalty.

This did not mean that the young people had absolutely no choice. Depending on the generosity or thoughtfulness of the parents, the wishes of the young people were taken into consideration before the final decision was made. Arranged marriages could be divided into two types: those in which the families made all arrangements without regard for their children's wishes, and those in which the children had an element of choice in selecting a mate from several candidates proposed by the parents. A nakōdo or marriage go-between assisted, sometimes from the very first and sometimes later on in the negotiations.

Some writers have seen at least four degrees of arrangement in the ways of choosing a husband or wife.

a. Blind marriage, in which bride and groom saw each other for the first time at their wedding. . .

b. Betrothed marriage, which meant that usually the bride and groom were betrothed by their parents during childhood. c. Marriage after a single interview, arranged by the parents, including the right of either the boy or the girl (if dissatisfied) to ask that negotiations be discontinued. d. Marriage after association, in which the young people, after being introduced, were allowed a considerable period of association for getting acquainted, their decision to be made by the end of the period. 1

As marriage was primarily for the benefit of the family, it was very important that a spouse be chosen from a family of proper status. This choice, it was felt, could not safely be turned over

${ }^{1}$ Ibid., pp. $48,49$. 
to young people, for although they physically were mature they were not yet considered mature enough in experience and judgment to be entrusted with such important decisions. Consequently, the responsibility for picking a spouse was left to the parents and, to a lesser extent, to all mature members of the clan. "Social maturity in the traditional Japanese concept was not attained by both sexes . . . before marriage, but (dependency) was to be continued for a considerable time thereafter." 1

Not only was the status of the family taken into consideration, but, in farm areas in particular, it was of vital importance that the prospective bride not only produce a male heir but was also a willing and productive worker in the fields.

In fact in some rural communities, the term "to take a wife" meant "increasing the labor supply" (tema wo fuyasu). If the bride turned out to be a poor worker she would be scorned by the other women, the family would lose face, and probably she would be sent back to her family, or go back of her own accord. 2

\section{Prestige of and Respect for Age.}

Prestige connected with age was another significant charactistic of the Japanese family. Age, sex, and position in the clan were interrelated and, in all oriental cultures influenced by the older Chinese culture, were criteria for prestige and privileges. Especially was this true of the eldest son in whom all'three of these factors combined to place him at the pinnacle of power and respect.

${ }^{1}$ Chiye Sano, reprinted in Silberman, Japanese Character and Culture (Tucson, Arizona: The University of Arizona Press, 1962), p. 113 .

2 Baber, Youth Looks at Marriage and the Family, p. 49. 
The use of various terms such as nempai (elder person, age of experience), sempai (senior, elder, superior), and sensei (teacher, 1iterally "the one born before") indicates the prestige which attends age. However, the last two of these terms are not limited in use to the actual chronological age. Sempai can refer to the one who has greater length of service or the one who has attained fame or popularity or training before the one speaking. And sensei has come to mean a teacher or any person with specialized training in a position of authority.

\section{Family Solidarity and Mutual Assistance}

Another characteristic of the traditional Japanese family was the very considerable degree of solidarity that attended the family or the household. The sense of responsibility for mutual assistance not only for members of the immediate family but also for near and even distant relatives is felt more keenly than it is in the West. Unlike the Western nuclear family, the Japanese family's fortunes did not end with the death of the family head but continued on as possessions, authority, and traditions were passed on from one generation to the next. This led to a sense of oneness and belonging, a loyalty to the family group that has had a marked affect not only on the family itself but also on Japanese society as a whole.

As Nakane Chie describes it, this same sense of solidarity has as a component characteristic a tendency toward clannishness.

A cohesive sense of group unity, as demonstrated in the operational mechanism of household and enterprise, is essential as the foundation of the individual's total emotional 
participation in the group; it helps to build a closed world and results in.. . group solidarity. At the same time, the independence of the group and the stability of the frame [see footnote explanation of her use of this term] both cultivated by this sense of unity, created a gulf between the group and others with similar attributes but outside the frame. I

It can be seen then, that this family solidarity had

clannishness as one of its accompanying attributes. Wareware

Nihonjin (we Japanese) is an expression that is often heard and is used to distinguish between "us" and "them." It indicates a trait which is typical of many Japanese and which seems to have its origin in the family solidarity and clannishness of the traditional family.

Family Ancestor Worship

As has been discussed, the individual in Japanese society was nothing except as he was part of a family. And the family was not an entity by itself but was closely bound to other households within the larger dōzoku (clan). The force that bound them all together in a strong, cohesive unity was ancestor worship. The living were the link between the past and the future members of the family. They were the representatives of the ancestral family and the trustees of its fortunes and reputation.

Japanese legal historians have described the ie as "a legal entity originally founded upon ancestor worship, whose purpose was the continuation of ancestor worship." ${ }^{2}$ Along with the family

${ }^{1}$ Chie Nakane, Japanese Society (Berkley, Calif.: University of California Press, 1970), pp. 19, 20. Frame is here used in the sense of locality, an institution, or a particular relationship which binds a set of individuals into one group.

${ }^{2}$ George B. Sansom, The Western World and Japan (New York: Alfred A. Knopt, 1951), p. 448. 
property and the family faith, the eldest son would inherit the responsibility for the ritualistic worship of the family ancestors who were represented by the ihai (memorial tablets) on the family kami-dana (god-shelf). He would also represent the family at memorial services for the dead at shrines, at the local Buddhist temple where his family was registered, and at the family grave.

Some common beliefs that form the foundation for ancestor worship in the family as practiced in the major Japanese religions are given by Ichiro Hori as follows: (1) emphasis on filial piety (kō) within the family system, (2) a deep-seated and common belief in spirits of the dead, (3) emphasis on on (debts or favors given by superiors, human or superhuman) and hōon (the return of on), and (4) the continuity between man and deity or ease in deification of human beings. 1

Although positive distinction is not possible, it seems fairly evident that there was a distinction between the gods who had always existed, or had existed for incalculable eons of time, and the gods who were a category of men whose lives had ceased but who were still concerned with the affairs of their descendants and their family fortunes. Prayers and gifts were at times offered to them and at other times for them.

of particular importance in Japanese ancestor worship was (and still is) the midsummer festival of the dead known as Bon. This festival was a high day in which the spirits of the ancestors returned

${ }^{1}$ Ichiro Hori, The Appearance of Individual Self-Consciousness in Japanese Religion and Its Historical Transformations, in Robert J. Smith, Ancestor Worship in Contemporary Japan (Stanford, Calif.: Stanford University Press, 1974), p. 6. 
to fellowship with the living family. It was based on a sutra known in Japanese as urabon-kyo that required homage "to the ancestors for seven generations." 1

An outstanding feature of these various ceremonies for the dead was that from start to finish they were primarily the responsibility not only of the priest but of the household and its members, especially the head of the family. ${ }^{2}$ Furthermore, in many families these ceremonies were thought of more as family or household duties rather than as religious activities. ${ }^{3}$

Whether it was a household duty or a religious activity is open to some question, but in any case the rationale for ancestor worship can be summed up by saying that there were various motives for this worship. Among them are the following: (1) a desire to help the spirits of the dead, (2) fear of retribution from angry ancestors who have not been properly cared for, (3) a desire to seek both personal protection and health and happiness for family members, (4) a simple wish to express gratitude to the ancestors for their past favors and to pledge to them observance of high moral standards so as not to bring shame upon them, and (5) a sincere show of respect, just as one shows respect to all superiors. 4

Thus it can be seen that for the typical traditional Japanese family, membership in the household was not for a few short years only but was conceived to be eternal, transcending death.

\section{${ }^{1}$ Robert J. Smith, Ancestor Worship in Contemporary Japan} (Stanford, Calif.: Stanford University Press, 1974), p. 15.

$$
2 \text { Ibid., p. 69. 3 Ibid., p. 116. } \quad{ }^{4} \text { Ibid., pp. 148, } 149 .
$$


"Thus the ie is a spiritual community, and ancestor worship is its religion." 1 . There is a distinction, however, between the Japanese and the Chinese family concerning who was worshipped. In Japanese ancestor worship "the recognized lineage of ancestors is fairly short, hardly going back further than those forefathers who live in the memory as quite concrete personal figures." 2

Collective Family Ownership of Wealth and Collective Decision Making

Emphasis on collective economic ownership of property and wealth, along with a collective decision-making process in which responsibility was shared, was also a characteristic of the Japanese family system. The head of the ie conceived of himself not as the sole owner of wealth and property by his own rights but as merely the living representative of the continuing family who had been entrusted to maintain and pass on these heritances to future generations. Because of this sense of collective ownership, property owners in particular were loath to part with the lands of their fathers and did so only after the family elders had arrived at a decision.

Decision-making within the family was always a group process arrived at by means of consensus. However, as Chie Nakane states, this consensus was often an ágreement in form only. "In the ideal traditional household in Japan, for example, opinions of the members of the household should always be held unanimousiy

\author{
${ }^{1}$ Ibid., 'p. 151 . \\ ${ }^{2}$ Nakane, Japanese Society, p. 140.
}


regardless of the issue and this normally meant that al1 members accepted the opinion of the household head," often times without

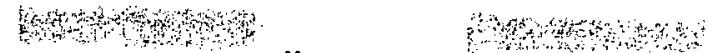

much discussion of the issue. "An expression of a contrary opinion to that of the head was considered a sign of misbehavior, disturbing the harmony of the group order." 1

Decision-making by group consensus was also found beyond the local household, in the clan, the village, and in society at large. Speaking of this process in society at large Professor Nakane states:

The Japanese ethic puts high value on the harmonious integration of group members, and so it is most important that a meeting should reach a unanimous conclusion; it should leave no one frustrated or dissatisfied, for this weakens village or group unity and solidarity. . . . In order to reach unanimity, they do not care how long it takes. Whatever time and trouble they may have in its procedure, all should reach a final consensus. . . . In the course of time dissension decreases, and consent increases. When it reaches a stage where support comes from about 70 percent of the members it is a sign of almost reaching a consensus. In the final stage the minority makes a concession. 2

One other aspect of the group decision-making process in Japanese society that has sprung out of the group consciousness of the family is "the tendency to steer away from the collision course of an either/or, yes or no, ultimatum. Rather, the Japanese prefer decision-making to contain various alternatives, certain options, so that a person can find a way out and not be put on the spot, which might result in embarrassment." 3
${ }^{I}$ Ibid., p. 13 .
2 Ibid., p. 146
3 Robert Lee, Stranger in the Land (London: Lutterworth Press, 1967), p. 160 . 
Harmony among all parties was the goal of group consensus. It was highly desired and although it often had only an appearance of concord, consensus was considered good because it resulted in collective responsibility.

Child Training and Discipline

in the Family

Another characteristic of the traditional family can be seen in the attitudes and practices concerning child training. Teaching the child to understand his role within the structure of society and how to act in any given situation in regard to those both above and below him in the hierarchy is the first objective in training the child. As one writer has expressed it, "It can be argued that the main thrust of the process of socialization of the Japanese, from childhood into maturity, is aimed at making him a good group member, first within his family, then in a peer group of schoolmates, and finally within his work group." 1

Children are highly cherished and desired but compared to the family in the Western society, especially during the early years of life, "they are treated with utmost indulgence. Physical aggression and the outward expression of anger are strongly disfavored. The opinions of one's fellows [constitute] a powerful force toward conformity, and identification with groups . . . is highly desired." 2

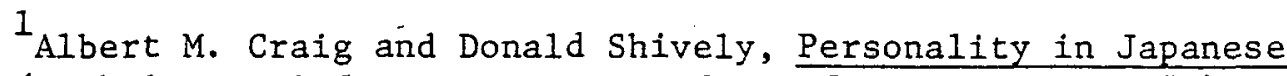
History (Berkeley, Calif.: University of California Press, 1970), p. 348 .

2 Edward Norbeck, Changing Japan (New York: Holt, Rinehart and Winston, 1965), p. 21 . 
When asked what trait most distinguished the Japanese from other peoples, one of Japan's leading psychiatrists, Takeo Doi, answered that it was

our amae feeling, which can be translated as "to depend upon and presume on the affections of someone close to you." It connotes the same kind of longing for dependency and belonging that a child has. In other societies this is a familiar relationship between child and parent, and perhaps between lovers. 1

In Japan, according to Doi, adults strongly cultivate such dependency relationships with older brother figures such as a senior in an office or the head of one's political faction. He believes that most Japanese behavior is influenced by such relationships which are developed in childhood. He further explains:

In the West you try to suppress amae, whereas we Japanese cultivate it. We indulge our babies and children from the beginning. They become so confident of our love that they can rebel and know they will be indulged. And when they finish school and enter companies, such amae relationships are automatically transferred to a colleague or superior. This accounts perhaps for the facility with which Japanese form groups and become dependent on the group leader. 2

A study of child training habits in Japan by Betty Lanham, an anthropologist, indicates that although discipline of children is less severe than in the West, it is not altogether absent. She writes :

Perhaps surprising to an American mother, would be the early emphasis upon orderliness, cleanliness, manners, and neatness. The early establishment of proper behavior and attitudes in relation to other children with whom the child plays is interesting, particularly the frequent admonition to refrain from envy.

${ }^{1}$ Japan Times, 16 August $1975 . \quad{ }^{2}$ Ibid.

3 Betty B. Lanham, "Aspects of Child Care in Japan: Preliminary Report," in Personal Character and Cultural Milieu, edited by Douglas G. Haring (Syracuse, New York: Syracuse University Press, 1956), pp. 565-83. 
Although this study was made in 1956 , sometime after the post-war era began, it indicates that even then children were treated rather indulgently in their early years and that the purpose of training was to teach proper attitudes and behavior towards authority and toward peers.

Loyalty, Obligation, and Duty as Motivating Factors

For the Westerner, perhaps the most difficult Japanese characteristic to comprehend is the unique sense of loyalty based upon obligation and duty to one's superiors. And yet without an understanding of this traditional characteristic one cannot fully sense the dynamics which controls the family. It permeates every aspect of Japanese life from infancy to old age and beyond the grave to one's ancestors. Obligations to one's family and clan, loyalty to one's company, obligation or debt to one's teacher, and loyalty to the country, as symbolized by the emperor, are all manifestations of this characteristic. The Japanese are motivated by on, hōon and giri, words which have no literal translations in English.

Ruth F. Benedict, in her best known work The Chrysanthemum and the Sword, explains giri and on as follows:

The word for "obligations" which covers a person's indebtedness from greatest to least is on. In Japanese usage of it, it is translated into English by a whole series of words from "obligations" and "loyalty" to "kindness" and "love," but these words distort its meaning. . . On is in all its uses a load, an indebtedness, a burden, which one carries as best one can. 1

$1_{\text {Ruth Benedict, The Chrysanthemum and the Sword, Patterns of }}$ Japanese Culture (Boston: Houghton Mifflin Co., 1946), p. 99. 
The burden of on is heavy and can never be fully repaid, but the obligation to repay (höon) remains with one forever.

In 1958, the Japanese National Comnission for UNESCO published a report on Japan and her people. The report pointed out the importance of giri in the social morals of Japan. A part of this report says:

The relationship of relatives and friends to each other, the relationship between farmers and tenants, masters and servants . . all were governed by this giri code. . . Nonconformance meant ostracization from one's companions. There were even cases when giri took precedence over the relationship between parents and children and between brothers. Sometimes, again, there were those who sacrificed their own lives, or who committed what they themselves thought to be wrong or evil, all in the name of giri. I (Emphasis supplied)

This sense of obligation, duty, and loyalty was epitomized in Bushido, the code of the samurai warriors of the Tokugawa era which stressed unquestioning loyalty and obedience and valued honor above life.

Bushido rests upon Shinto principles; it is consanguineous and concrete; it is strengthened by and polished by the tranquility of Buddhism and the realism of Confucius. The teaching started in the twelfth century under Yoritomo and continued to be cultivated and embellished for six hundred years. 2

In the Hagakura, the so-called bible of Bushido, this trait of giri or loyalty and obligation to one's lord or clan is well illustrated in the saying: "Nothing we need except the vow we made to our master. Throw me into hell or strike me with the god's

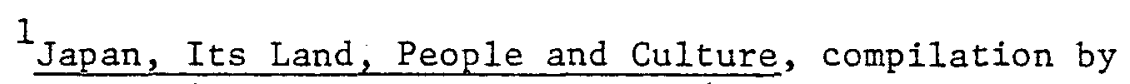
Japanese National Commission for UNESCO (Tokyo: Printing Bureau, Japanese Government, 1958), p. 942.

${ }^{2}$ Aikawa and Leavenworth, Mind of Japan, pp. 39, 40. 
punishment; I don't care, if I may be of any service to the master of my clan."I. This sense of giri was deeply instilled in the military as is evidenced by the soldiers who, decades after the end of World War II, refused to surrender until their commanding officer could be found to release them from their obligation and responsibility. Although giri, as demonstrated by the samurai of the Tokugawa era or the military during recent Japanese wars, may be extreme in expression, yet this same sense of obligation and loyalty in modified form is still part of the Japanese personality. Professor Minami, in his best selling book Psychology of the Japanese People, deals at length with this aspect of the Japanese personality. He states that giri

is a promise to act in a fitting manner according to where one stands in relation to others in the social structure And the promise, unlike modern obligation, is not grounded in rights. Giri is rather a promise of a certain attitude or conduct toward all of the people who surround one. 2

Giri also "implies that one is satisfied with one's lot in the existing society; it is a forced promise to rationalize the practice of no self, acquiring the spirits of service above self." 3 This sense of giri is manifested in various relationships; between parent and child, husband and wife, and between a person and his relatives, friends, superiors, or inferiors. It has been one of the chief barriers for many Japanese in their acceptance of Christianity. On

${ }^{1}$ Ibid., p. 40.

${ }^{2}$ Minami, Psychology of the Japanese People, pp. 157, 158.

3 Ibid., p. 158. 
the other hand, it has been for many other Japanese that quality which has bound them so loyally to Christ and the church.

\section{Strengths and Weaknesses of the Traditional Family}

This brief survey of some of the characteristics of the traditional Japanese family demonstrates that it possessed both strengths and weaknesses. Individuality and selfhood were never fully developed, women were held in semi-servitude, and a fixed hierarchy of rank and prestige often stiffled initiative and development. Yet the strengths and advantages of the traditional family were also many.

The traditional Japanese family was more durable than the conjugal or nuclear family. It developed stronger loyalties and a deep sense of responsibility to others in the family. It emphasized respect for the aged, a close interdependence between generations, the value of hard work, industry, honesty, and loyalty. These values were taught not so much by precept as by example. They were long-standing family traits bequeathed to each succeeding generation rather than characteristics of a few outstanding individuals.

The traditional family system was entrusted with great responsibility as a stabilizing force in society. It was influential in producing a strong society that has had remarkable unity, cohesion, and harmony. And it has greatly contributed to the making of a unique people and a strong nation.

The old family system had certain definite advantages for its members that largely compensated them for the hardships and the 
deprivations of their personal freedoms. It demanded much of each family member but it also was dependable and powerful in giving aid in time of need. It was a society of mutual help which cared for the aged, the $i 11$, the crippled, and the infirm among family members without depending on government agencies, religious institutions, and other social organizations. It was better able than a lone individual to amass the capital for an important. economic undertaking.

Lafcadio Hearn, who married a Japanese woman and lived for many years in Japan, had as unique an opportunity as any Westerner to observe the traditional Japanese family. In 1905 he wrote the following concerning the Japanese family:

Such was the patriarchal family in old times; yet it is probable that conditions were really better than the laws and the customs would suggest. The race is a joyous and kindly one; and it discovered, long centuries ago, many ways of smoothing the difficulties of life, and of modifying the harsher exactions of $\mathrm{law}$ and custom. 1

The next task will be to trace in history the development of this unique family system, some of the influences which molded it, and some of the continuing influences that even today are changing it.

\footnotetext{
$1_{\text {Hearn, Interpretation, }}$ p. 74.
} 
CHAPTER III

\section{THE CHANGING JAPANESE FAIIIY}

Without doubt, the Japanese family is unique--so much so that some have thought that this characteristic family system could be traced as far back as the beginnings of Japanese history. However, this may be assuming too much. It is true that psychologically and culturally the Japanese people are unusually homogeneous. It is also true that the distinctive characteristics of Japanese social life can be traced back in history. for many generations with very little change. However, this does not mean that the "traditional family" has always existed. What is true, is that the family system is a product of Japanese society itself, which in turn has undergone continuous change from pressures and forces in its historical development as has every other country.

The task of this chapter is to review the literature on this fascinating topic in order to identify some of the various factors and forces in history and the unique Japanese culture that have helped to produce what has become known as the traditional Japanese family. Perhaps an even more difficult task will be to examine the presently emerging family in order to note in what ways it has changed from that of the traditional family. An attempt will also be made to note the characteristics that have not changed and which remain in Japanese society. today. 
As the reader becomes acquainted with the forces at work in society in general and in the family in particular and as he develops a keen sense of awareness of the values and motivational forces in society today, he can as a Christian work more effectively with and not against Japanese culture in fulfilling the "great commission" given by Christ.

\section{Early Influences}

Takaaki Aikawa, president of Kanto Gakuin, sees three formative factors in the geography and early history of the Japanese people that have had an influence on their culture, their ways of thinking, and the development of their family system. The first of these is "the geographical fact that Japan is a volcanic island country, running from north to south in the path of seasonal typhoons. Earthquakes, typhoons, and floods are regular visitors, owing to the volcanic nature of Japan."1 The violence of nature was so repetitive and so overwhelming that the Japanese lost their will to fight back, accepted the violence as part of nature, and waited patiently for the beauty and bounty that would eventually come.

Thus they never tried to conquer nature but resignedly learned to live with nature. Dr. Aikawa believes this to be one of the factors that has helped to form the Japanese personality. They lost their will to fight against nature, "consequently they lost their sense of independence and never developed an ego-consciousness. ${ }^{2}$ He sees the fact

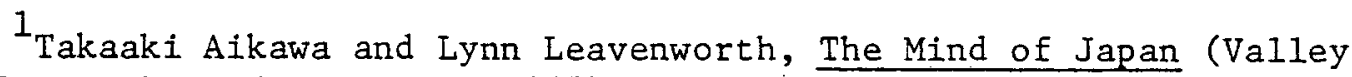
Forge, Pa.: The Judson Press, 1967), p. 25. 
that the Japanese seldom say "no" and that their "yes" does not always mean real acquiescence as an indication of this lack of selfawareness. "They just open the door and wait until the things which are brought in have decayed and changed into 'natural' things in their indigenous surroundings and in the inevitable passage of time. Westerners," he says, "have almost no means of fighting against this ghostlike indifference." 1

The second formative factor that Aikawa noted is the fact that the Japanese live in a small island country surrounded by a hostile sea which separates them from other peoples. Because of this, the early Japanese people failed to establish a meaningful dialogue with other peoples. Their long isolation as a homogeneous people had a bearing on the development of the distinctive groupconsciousness which is so characteristic of Japanese social life even today.

This isolation however during so much of their history also protected them from foreign, conquering armies. Compared to other peoples in the world their history has been relatively peaceful, with few wars such as those which devasted much of Europe and other parts of Asia. The few wars that their history has recorded were more like family squabbles and local feudal rebellions.

Thus the need for weapons as a means of self-defense was not strongly developed. At a later date in the history of Japan weapons were outlawed for everyone except the warrior and ruling classes.

$$
{ }^{1} \text { Ibid., p. } 26 \text {. }
$$


This procedure was most extraordinary, for no other country has ever been known to be successful in forcing people to live without the right to hold weapons for so long a period as four hundred years. . . . The lack of weapons meant that the people could not protect their rights with force before their rulers [and] the only ethics developed.. . was considered inseparable from blood and locality. ${ }^{1}$. (Emphasis supplied)

Furthermore, this developing ethics contained no moral

teachings regarding strangers. Strangers were

- . outsiders requiring some other code of behavior. . . Herein lies the Japanese abnormal hatred and fear of foreigners and at the same time their overestimation and worship of strangers. This tradition of making sharp distinctions between "insiders" and "outsiders," is not a thing of the past, but is still a factor in the labor union movements and in the approaches to political strategy and to international relations. 2

The third factor influencing Japanese ways of thinking, according to Aikawa, was the "particularism of the family system which developed around the paddy-field rice culture." ${ }^{3}$ Because of the mountainous nature of the country, an extensive rice production system could best be owned and operated by the combined efforts of a closely knit group of people. He explains:

People who belonged to the same rice nursery came to form a pseudo-family, and the members of this strongly united group were given the same family name. This family name was called a myoji, the literal translation of which is "the man of the same seedling." Thus the rice nursery was the basis of the old family system in the rural villages of Japan. 4 (Emphasis supplied)

Particularism, the exclusive attention or devotion to one's own particular group or family, was thus born. Two concepts that sprang up from this form of particularism are called on and shinchi. On was the sense of obligation one felt to one's own family or

$$
\begin{array}{ll}
{ }^{1} \text { Ibid., pp. 27, 28. } & 2 \text { Ibid., p. } 28 . \\
{ }^{3} \text { Ibid. } & { }^{4} \text { Ibid. , pp. } 28,29 .
\end{array}
$$


group, and shinchi was the sense of security which could be attained by becoming one with the whole group. There could be "no meaning for the individual," according to Aikawa, "in this type of interdependence of the group for everything. "1

Inextricably woven within the fabric of Japanese society and culture from its earliest days, and a powerful molder of the values, practices, and characteristics of the family is Shinto, the indigenous faith of the Japanese people. Actually, it is "more than a religious faith. It is an amalgam of attitudes, ideas, and ways of doing things that, through two milleniums and more have become an integral part of the way of life of the Japanese people." 2 Like Judaism, Shinto can be termed a "racial religion." 3

Originally, Shinto was largely unorganized and had hardly any system of doctrines. However, with its myths which explained the divine origin of the Japanese and which helped maintain their reverence towards the ruling family who was said to have descended from the sun-goddess it played a strong part in maintaining a sense of national unity and social solidarity. "The idea of family perpetuation, and the importance of communal life played . . important parts; the virtues of valor and fidelity, as well as the faithful observance of family traditions, were always integral factors of the indigenous religion." 4

${ }^{1}$ Ibid., p. 29.

2 Sokyo Ono, Shinto, the Kami Way (Tokyo, Japan: Charles E. Tuttle, 1962), p. 3.

${ }^{3}$ Ibid., p. 111. Also Isaiah Ben-Dasan, The Japanese and the Jews (New York: John Weatherhil1, Inc., 1972), p. $105 f$.

4 Masaharu Anesaki, History of Japanese Religions (London: Kegan Paul, Trench, Trubner and Co., Ltd., 1930), pp. 6, 7 . 
Shinto was pre-eminently the religion of an agricultural people who lived close to and in harmony with nature, and it helped to develop a love of beauty in simple, natural things. It was

- . an unorganized worship of spirits. It was rooted in the instinctive being of human nature, feeling itself in communion with the living forces of the world and showed its vitality in the communal cult. For the worship was often connected with local legends and communal customs, and the deities thus worshipped were mostly considered to be the ancestral or tutelary spirits of the communes. 1

Among the yaoyorozu kami (eight myriads of kami) or spirits and gods to be worshipped were the spirits of plants and corn,

- . the qualities of growth, fertility and production, natural phenomena, such as wind and thunder, natural objects, such as sun, mountains, rivers, trees, and rocks; some animals; and ancestral spirits. Also regarded as kami were the guardian spirits of the land, occupations, and skills; the spirits of national heroes, and those who had contributed to civilization, culture and human welfare. 2

Although Shinto has changed greatly over the centuries, it still has a central place in the society and culture of Japan. Many homes still have a smal1, private Shinto shrine in their gardens, but in most cases there is only a high, simple kami-dana (god-shelf) on which a miniature shrine is placed.

With the introduction of Confucianism and Buddhism, ancestor worship was more formalized and ritualized, however, it was not unknown among the populace before the advent of those religions. In a simplified form it was a basic part of early Shinto. Also under the clan system which developed early, Shinto with its

$$
\begin{aligned}
& { }^{1} \text { Ibid., p. } 22 . \\
& 2^{2} \text { no, Shinto, the Kami Way, p. } 7 .
\end{aligned}
$$


kami-rites became the spiritual center of society. "Human relations were essentially the relationship of those who mutually served the kami. Human behavior was to a large extent determined by the relationship established in performing kami-rites, that is, worship or matsuri." 1

Influences of Confucian Thought and Buddhist Belief

Although Japan was never dominated militarily or politically by the mainland colossus to the west, its moral and ethical values were enormously molded by the more advanced civilization of China. of special significance to the family system were the ethical teachings of Confucianism and the principles, teachings, and practices of Buddhism which began in the sixth and seventh centuries A.D.

The teachings of Confucius introduced even before Buddhism had a profound effect on the Japanese family. These principles - . were well suited to the Japanese social conditions of the time, and these, in secular rather than religious guise formed the core of the formal teachings. Loyalty to superiors, filial piety and rei, a term, often translated into English as "etiquette," that implies an ethical code of interclass and interpersonal behavior--were prime virtues. 2

Confucianism as a system of moral teachings was

founded on a patriarchal system of community. . . In it the greatest natural bonds of humanity are five, and they are: (1) sovereign and subjects, (2) father (implying also mother) and child, (3) husband and wife, (4) brothers (implying also sisters) and (5) friends. 3

${ }^{1}$ Ibid., p. 105 .

2 Edward Norbeck, Changing Japan (New York: Holt, Rinehart and Winston, 1965), p. 8.

3 Kencho Suyematsu, The Risen Sun (New York: E. P. Dutton and Co., 1905), pp. 177-179. 
Springing out of these five were two others, the relationship between the elder and the younger and the relationship between master and pupil. The chief point of these principles can be summed up in two points, loyalty and filial piety.

To Confucian thought lasting "happiness and propriety would prevail in society if only every one would behave 'correctly' as a family member--which primarily meant that no one should fail in his filial obligation. The relationship between a ruler and his subjects . . was parallel to that of a father and his children." ${ }^{1}$

Historian George B. Sansom points out that the central doctrine of Confucianism as well as the basic unit of its social and political system is "the cult of the family. . . The highest, almost the only, duty of a man is the duty to his parents, and if Confucianism can be called a religion, it is the religion of filial piety. ${ }^{2}$

The Japanese historian Anesaki noted the leading role played by Confucianism in the formation of the institutions and culture of Japan. He further noted the essence of Confucianism's moral and social conduct as being "subordination, obedience, and dutifulness on the part of each individual." ${ }^{3}$ He goes on to say that for the Confucianist "the duty of each individual [was] to live and act in

1William J. Goode, The Family (Englewood Cliffs, New Jersey: Prentice Hall, Inc., 1964), p. 2.

${ }^{2}$ George B. Sansom, Japan, A Short Cultural History (New York: D. Appleton-Century Co., 1943), pp. 113, 114 .

3 Masaharu Anesaki, Religious Life of the Japanese People (Revised by Hideo Kishimoto, Tokyo: Kokusai Bunka Shinkokai, 1961), pp. 37,38 . 
accordance with the status ordained for him in the hierarchy of social life," for human life was seen as an image reflecting heaven, or Tien. ${ }^{1}$

However, like everything else which the Japanese adopted, the teachings of Confucius: were modified to suit the different structure of the family in Japan. In China, for instance, filial piety took precedence over loyalty, but in Japan loyalty stood first. In China, loyalty was owed to a vast extended clan often numbering tens of thousands of people. This was different in Japan where loyalty was due to a relatively sma11, more intimate group of known relatives.

Still another difference was that in China obedience and loyalty were always to a temporary, bureaucratic mandarin who was a stranger in the district, while in Japan that loyalty and obedience was to a resident overlord. "What was important in Japan, was that one was the fief of Satsuma or the fief of Hizan. A man's ties were to his fief." ${ }^{2}$

In spite of the adaptations and modifications of Confucianism, it is difficult to overestimate the significant effect of these moral and ethical principles, and the practices that grew out of them, on the Japanese family.

Other imports from China were the moral and religious teachings of Buddhism. The impact on the family of these teachings

$1_{\text {Ibid., p. } 38 .}$

2 Ruth Benedict, The Chrysanthemum and the Sword, Patterns of Japanese Culture (Boston: Houghton Mifflin Co., 1946), p. 51. 
were also fundamental and far-reaching. Whereas Confucianism's concern was for ethical principles with which to guide the living, Buddhism with its emphasis on nirvana and re-incarnation focused its attention on the dead, reinforcing the emphasis of ancestor worship which had been present in the more primitive, indigenous religion of pre-Buddhist times.

Again, changes were made in the ancestor worship as practiced in China.

In Japan there is no cult of veneration of remote ancestors and at shrines where "common people" worship all villagers join together without having to prove their common ancestry. The reverence due one's ancestors is paid at a quite different shrine, in the family living room where only six or seven recent dead are honored. 1

The underlying principle of ancestor worship was that the welfare of the living depends upon the welfare of the dead.

Under the influence of this idea, and of the cult based upon it, were developed the early organization of the family, the laws regarding property and succession (and) the whole structure, in short, of ancient society. . . The constitution of the patriarchal family everywhere derives from its ancestral cult. 2

The net effect of Shintoism, Buddhism, and Confucianism was to reinforce the household hierarchy and to repress all conflicting loyalties. And this was accomplished through the medium of ancestor worship and its built-in loyalties and obligations within the vertical relationships that society prescribed.

${ }^{1}$ Ibid., p. 52 .

2Lafcadio Hearn, Japan, An Attempt at Interpretation (Tokyo: Charles E. Tuttle Co., 1955), p. 55. 
The Buddhist doctrines of karma (reincarnation) greatly influenced the life of the ordinary people. It induced the people to submit themselves to the necessity of fate. In its extreme form, it amounted to a teaching of non-resistance towards anything evil or harmful, for every occurence in life, whatever it might be, was considered to be an irresistible consequence of one's own karma, or former existence. 1

However, this Buddhist fatalism and its teachings of calm $\therefore{ }^{*}$ resignation, forebearance,'meekness, toleration and renunciation of self for a higher cause produced noteworthy moral effects, and this, in association with the Confucian ethical teachings regarding the primacy of obedience and loyalty, placed a lasting mark on the Japanese personality and the Japanese family.

Two outstanding events in history made the influence of Buddhism even more universal in Japan. Whatever its early form and development, Buddhism before the Tokugawa era had neither supplanted Shintoism and its various gods nor remained unchanged itself in its contact with the Japanese and their various religious beliefs and practices. The Buddhism of those early days was a "vast conglomeration of cults and faiths." 2

The first of these events was an action taken by the central government in the early years of the Tokugawa era that had the effect

\footnotetext{
${ }^{1}$ Anesaki, History of Japanese Religions, p. 74.

2 Shunzō Sakamaki, "Shintō: Japanese Ethnocentrism," in
} Charles A. Moore, ed., The Japanese Mind: Essentials of Japanese Philosophy and Culture, quoted in Robert J. Smith, Ancestor Worship in Contemporary Japan (Stanford, Calif.: Stanford University Press, 1974), p. 13 . 
of making Buddhism the family religion of all of the people. As a means of ensuring that no Christians survived the vigorous suppression of their faith and that the local populace was loyal,

the government required every person to affiliate with the Buddhist temple. In 1640 a bureau was established within the Tokugawa central administration to supervise the registration of the population by Buddhist sect and temple. . . These registers were renewed annually. 1

In this way ancestor worship and Buddhism were exploited to accomplish the purpose of the government. In so doing the turning point in the fortunes of Buddhism was reached.

The other historical event took place a little over two hundred years later following the Meiji Restoration of 1868. The new government's efforts to promote its own goal of nationalism by linking Shinto-emperor worship (tennen sühai) with Buddhist ancestor worship (sosen sūhai) proved remarkably successful. Thus "the fusion of the indigenous gods and the alien buddhas simply strengthened the central role of ancestor veneration in the theory of the state." 2 Without a doubt, these events have had a direct influence on maintaining the basic beliefs and practices of the traditional patriarchal family system of Japan.

\section{Influences of the Tokugawa Era (1603-1868)}

As we have noted, the Japanese family system is a product of society itself, being molded by Japan's unique geographical features and the vicissitudes of its history and culture. In spite

${ }^{1}$ Robert J. Smith, Ancestor Worship in Contemporary Japan (Stanford, Calif.: Stanford University Press, 1974), p. 21.

$$
{ }^{2} \text { Ibid., p. } 4 .
$$


of the family's venerable position in the institutional hierarchy, it has been called upon to do its full share of changing. However, the patterns of change have been so gradual that it seemed at times that the family system was fixed and changeless. But they were not. Dramatic changes in the family system were brought about during a period of prolonged feudal dictatorship culminating in the Tokugawa era. Perhaps more than any other single influence or period of history, this era of military dictatorship molded and fixed the Japanese personal and family characteristics which have come to be spoken of as "traditional."

Just how great the changes effected by these years of autocratic. rule and slave-like submissiveness were can be seen by investigating the pre-Tokugawa Japanese personality. Douglas G. Haring, writing on the Japanese national characteristics in those earlier times writes:

No reader of Manyoshu--an eighth-century anthology of poetry--or of the eleventh-century novel Tale of Genji would apply the formula "compulsive personality" to the Japanese of those far-off centuries. They loved, brawled with abandon, bore obligations 1ightly, were not overawed by ancestors or Emperors, and manifested no taut preoccupation with ceremonial suicide. Court nobles and their ladies dallied . . . in Chinese aesthetics with never a glance at Confucian moral codes; Buddhist theology was attenuated till it became a fashionable, genteel stimulus to refined melancholy while. its asceticism and philosophical pessimism were ignored blandly. 1

Edwin Reischauer also saw in the pre-Tokugawa era a different personality than that which emerged two and a half centuries later at the beginning of the Meiji era (1868-1912). He says:

1 Douglas G. Haring, "Japanese National Character," Yale Review 42 (1953), in Japanese Character and Culture, edited by Bernard S. Silberman (Tucson, Arizona: University of Arizona Press, 1962), p. 392 . 
The Japanese seem to have been an openly emotional and unrepressed people during much of their history. . . . The Confucian insistance on decorum and the "doctrine of the mean" . . made relatively little impression on the ancient Japanese. - . There was nothing moderate about them. The Portuguese and Spaniards in the sixteenth century did not find them unduly repressed emotionally or more prone to conformity than the Europeans themselves. 1

How did this radical change in society that so fixed and formed the Japanese family system come about? One cannot hope to understand fully the family of today without a deep understanding of the forces that were at work during these cricial centuries when the Tokugawa Shungunate ruled Japan. The beginnings of these changes can be traced back several centuries before the Tokugawa era when in 1185 the Minamoto faction defeated the Tairas. At that time the successful leader Minamoto Yoritomo left the emperor on the throne but stripped him of all real power and, adopting for himself the title of "Shogun," took over the reigns of government.

The centuries that followed were characterized by civil unrest and cumulative governmental impotence. Late in the sixteenth century three outstanding dictators came on the scene in close succession; they unified the nation and laid the foundation for centuries of peace. Oda Nobunaga and Toyotomi Hideyoshi, military leaders of outstanding ability, were followed by Tokugawa Iyeyasu, a genius of dictatorial organization. It was he who established a system of rule so firmly that the House of Tokugawa dominated Japan for two and a half centuries--"the centuries that shaped the Japanese

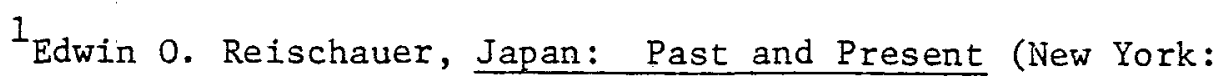
Alfred A. Knopf, 1946), p. 80. 
character as it continued up to the Second World War" ${ }^{I}$ and, to a large extent, can be seen even today.

This political system enforced and maintained by a strict division of the populace into social classes resulted in "the establishment of a state of domestic peace as complete as that enjoyed by any people at any time." ${ }^{2}$ Incredibly detailed regulations prescribed the type house, dress, food, and etiquette of each class and these were enforced on pain of severe punishment. "In principle, no man could rise above the class in which he was born, for it was the purpose of the rulers by legislating against change, to found a self-perpetuating state." ${ }^{3}$

In order to keep an eye on the activities of the daimyo, the people of the highest class, the government required them to spend half their time in the capital. The other half of the time they were permitted to look after their affairs within their local domains but their families had to be left behind as hostages. Loyalty to one's superiors was upheld as the supreme virtue, and a system of espionage kept everyone suspicious, even of his own household.

Enforcement of the rigorous rules and regulations was entrusted to the samurai, the professional warriors. The effect of this has been described as follows:

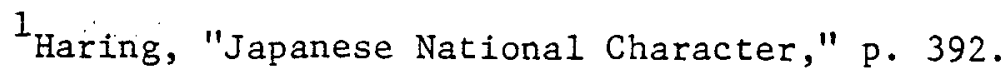
2 Ibid.

${ }^{3}$ Sansom, Japan, A Short Cultural History, p. 29.
} 
Professional warriors [were] authorized to decapitate on the spot anyone of lesser status whose conduct was "other than expected." The price of survival was constant vigilance, meticulous conformity to the numerous codes, and cultivation of a smiling face-or at least a "deadpan"--regardless of real emotions. The survivors were those who learned in early childhood to keep their own counsel, trust no one, and conform fanatically to whatever might be ordered. 1

Thus the Confucian emphasis on respect for authority and loyalty in the family systems became a powerful tool in the hands of the Tokugawa dictatorship. Not only did it maintain the status quo but it also molded and formed the family characteristics that, although modified by recent changes, are still powerful forces on the Japanese people.

As a means of developing and strengthening this political system, the code of conduct known as Bushido, the way of the bushi (warrior), was widely propagated. It was based to a large extent on Confucian teachings of the virtue or loyalty (chügi). Although this code of values and behavior was designed primarily for the samurai class, it was by no means restricted to them alone, for it was taught as a guiding principle in the home and affected to some extent all strata of society.

At the top of the list of Bushido qualities was loyalty, closely followed by filial piety.

The training of the child in filial piety was so that he might fulfill loyalty as an adult. Loyalty and filial piety tended to be very closely linked, almost identified with each other, and were connected with obedience and righteousness, economy and diligence. All demanded selfless devotion to superiors,

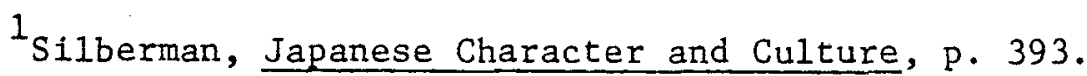


a minimum of personal consumption, and a vigorous prosecution of daily tasks and duties. 1

This system of values and ethics embodied in the Bushido code became, in fact, the national ethic in the Tokugawa era and, to a great extent, in modern times as well. As one Japanese writer has described it, it was the "cornerstone of national morals." 2

Thus Reischauer states:

The bellicose, adventurous Japanese of the sixteenth century became by the nineteenth century a docile people looking meekly to their rulers for all orders from above. They grew accustomed to firmly established patterns of conduct. A thousand rules of etiquette supplemented instructions from their rulers and governed all their actions. 3

\section{Influences of the Meiji Restoration}

The family patterns, along with other social and political structures, were relatively stable for so long that it seemed as though they were changeless. However, behind the feudal facade signs of social change were evident. By the mid-nineteenth century these changes were long overdue. In July 1853, Commodore Matthew C. Perry and his "black ships" arrived in Uraga Bay and two and a half centuries of seclusion ended. Five years later the last of the Tokugawa forces surrendered their authority to the emperor and what came to be known as the "restoration" took place.

Belatediy, but with breathtaking speed, reforms were initiated by the new government. The government's one goal was to help Japan

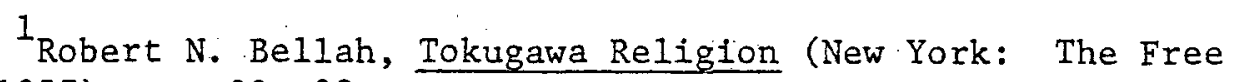
Press, 1957), pp. 93, 98.

2 Tasuke Kawakami, "Bushido in Its Formative Period," Annals of the Hitotsubashi Academy 3 (1952), p. 83, in Bellah, p. 90 .

${ }^{3}$ Reischauer, Japan: Past and Present, p. 94. 
catch up to the rest of the world and take its place with the major world powers. The new leadership, coming largely from samurai background, determined to make Japan a world power without delay. However, these new leaders were surprisingly far-sighted in their approach to the task, for they realized that to achieve military strength great changes would also be needed in the economic, social, and intellectual systems of the nation. To accomplish these changes they studied, borrowed, and assimilated those elements of Western civilization which they felt were best suited to their purposes.

The Japanese writer G. Munakata, in his study of the changes of the Japanese family system, discusses how the new leaders went about their task. ${ }^{1}$ They realized that in order to accomplish their purpose they must develop a social and political ideology that would be powerful enough to galvanize the will and mind of the nation and would form the all-inclusive basis for their goals.

What finally grew out of this study by the Japanese government became known as "kokutai shisō, the national polity of Japan, the unique characteristic of Japanese body politic, and the inner mystical force of the Japanese nation. It became the keynote of Japanese thought, and later the compulsory 'mind' of Japanese subjects under the military." 2

This was all accomplished in the name of patriotism, Japan's manifest destiny, by renewing the ancient, traditional value of

${ }^{1}$ Gan Munakata, Nihon no Kazoku Seido no Hensen to Toshika (Changes in the Japanese Family System and Organization), article in vol. 8 of Shakai Kyoiku Series (Social Education) (Tokyo: Jochi Daigaku Press, 1968), pp. 23-26.

${ }^{2}$ Aikawa and Leavenworth, Mind of Japan, p. 158. 
Japanese culture. The leadership attempted to make Shinto the national religion, tying in the early indigenous beliefs concerning nature and ancestor worship with the ideologies, ethical and moral values of Buddhism and Confucianism and the Bushido Code. All of this was tied to worship of the emperor who, they taught, had descended from the gods, who was head over all the Japanese clans, and who deserved honor, obedience, and worship as the father of a family.

By the end of the third decade of the Meiji era much progress had been made in accomplishing national goals set by the government. This progress was greatly assisted by three separate actions: ${ }^{1}$ (1) the promulgation of a new constitution, (2) the enforcement of the Imperial Rescript on Education, and (3) the inauguration of the military conscription system which became the basis for the new army. The Meiji leadership, although ending the outward forms of the feudal system and institution of a semi-democratic capitalistic system, sternly enforced the continuation of the patriarchal family system by means of the Meiji Minpo, a law enacted in 1898 which legalized the family system concerning rights and inheritance. This Meiji Minpo law, according to Professor Arichi, of the Kyushu University, affected and controlled the thinking of the nation and its peoples in three ways: ${ }^{2}$ it promoted and developed the system of, emperor worship; it re-emphasized the indigenous system of worship

${ }^{1}$ Article by Toru Arichi in Vol. 8 of Kazoku (Family) (Tokyo, Kobundo, 1974), p. 51.

$$
{ }^{2} \text { Ibid., 6, 7, 28-53. }
$$


based on ancestor worship and the patriarchal family system; and, by means of the Imperial Rescript on Education, it developed a system of ethical and moral values that greatly helped to mold the people for the accomplishment of national goals.

Concerning this institution of universal education Edwin Reischauer states that it "became a tool of the government, training obedient and reliable subjects who could serve as technically efficient cogs in the complicated machinery of the modern state. "1 These dramatically swift changes enabled Japan in a few short decades to grow in power to such an extent that it was able to defeat the Russian colossus in battle, develop an expanding empire of its own, and join the "big powers" of the world. These changes affected not only the political and military systems but every other part of life also, including the family system. However, the traditional family characteristics which had been fixed so firmly during the long years of the Tokugawa era were not entirely obliterated. Although the family was modified and its features somewhat softened, its basic characteristics remained clearly recognizable.

Some of the forces that were let loose during the Meiji era and that have had an effect on the present family system will be briefly discussed. However, it will be noted, these influences for modification and change in the family were to some extent counterbalanced by other influences which prevented the radical changes in the family that might have been expected. Many of these same

${ }^{1}$ Reischauer, Japan: Past and Present, pp. 128, 129. 
influences for change which began at that time continued to expand, reaching their maximum effectiveness only in recent years.

First to be mentioned is the contact with the culture, values, and institutions of Western civilization. Previously it had been Eastern civilization which had largely influenced Japanese society. Thought patterns from India, China, and Korea molded Japan's way of life and affected the individual and the family as well as forms of art, literature, and government.

Although it took time for the philosophies and literature of the West to affect the common man, these were now open for study by the educated classes. This meant that the seeds of democracy and the values and thoughts of Western man were examined, and subtle changes in all areas of life were evident.

Christianity entered Japan for the second time shortly after the coming of Admiral Perry. Its message of the dignity of man, the value of a soul, God's standard of morality, and the equality of all, men and women, educated and ignorant, samurai and peasant alike, had its leavening affect, too, on the family system and on the growth of individualism.

Although Christianity never caught on with the masses, its influence reached far beyond what the number of its adherents might indicate, for it found "good ground" in the hearts of many of the former samurai.

They saw in Christianity, not only a means of reclaiming status, but also a new dynamic for transforming Japanese society. In search of a new role, and challenged by the teachings of the 
Bible, they responded with a fervent loyalty to God and the church that was reminiscent of the loyalty previously pledged to their feudal lord. 1

"We embraced Christianity," one of these early samuraiChristians stated, "because we have believed that it fulfills the spirit and the real import of Confucianism. "2 From a study of the diaries some of the early Christians kept, it is evident that many of them saw in Christianity not the destroyer of their old values but the fulfiller and completer of these concepts and goals as found in Buddhism, Confucianism, and their samurai moral code. Another important factor of the new era which had a significant effect on the family structure and practices was industrialization. This developed in connection with Japan's race for prestige and power. It made jobs available for the peasants, freeing them from the farm and the fixed hierarchical way of life to which they were formerly bound. No longer were prestige and power limited by accident of birth. Jobs meant money and the potential for freedom of action based upon personal initiative and ability. This trend of movement from the country to the city which began under the peace-induced prosperity and economic development of the Tokugawa era expanded into a growing stream in the Meiji era and has today become a flood.

Thus the Meiji Restoration ushered in a period of rapid growth in the nation's power. And rather than changing the characteristic of the traditional family, the Meiji era helped to

$1_{\text {Robert Lee, Stranger in the Land (London: Lutterworth }}$ Press, 1967), p. 37. 
fix even more firmly the family values which had developed during the Tokugawa years. However, the forces it loosed eventually resulted in significant changes in the patterns, practices, and values of the family.

\section{Recent Influences}

In every sense of the word, a new age dawned for Japan with the surrender of her military forces on August 14, 1945. Reischauer stated, "The coming of Perry to Japan in 1853 resulted in profound changes in Japanese life. The much more dramatic coming of General MacArthur to Japan in 1945 may bring equally profound changes." I These words written shortly after the war have proved true.

For the first time in her long history Japan, as a nation, had been defeated and was occupied by foreign military forces. This proved to be not only a traumatic experience for the nation but has also produced the most dramatic and accelerated rate of change in her history. Changes are still taking place and no doubt will continue to take place for years to come.

These changes in society have come about not so much by deliberate planning as by new forces, that began working in society. A few of the most important of these that have affected the family w111 be noted.

One important and obvious influence was the intimate and prolonged contact with Western society and civilization. The contact this time differed from that of the Meiji era when selected

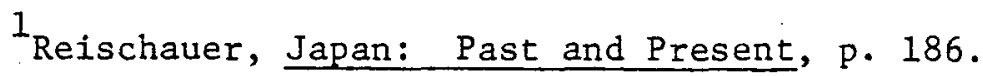


individuals went abroad and carefully choose what they desired to adopt for their own purposes. Now, contact was on the part of a much larger segment of the population and it was not a matter of picking and choosing what the leadership wanted. During the occupation every area of life was affected by several hundred thousand youthful representatives of all that was bad and good in Western society--the occupying troops. Their dress, their food, their houses, their amusements, their approach to life, their social and personal lives were observed.

This direct and intimate contact between East and West was a learning process on both sides. As has often been noted by observers of this scene, one particular area of learning which seemed to be pleasing to both sides was the meeting of the Japanese woman and the American man. Pearl Buck aptly describes what took place as follows:

It was into this clearly defined relationship, traditional in Japan between man and woman, that the American man came and looked about him with delight approaching awe. . . . What he found was a compliant, gay female who was enchanted by him, and in return gave him her response, and one so complete, that he felt for the first time he had discovered woman. . . A And he .. . gave her a courtesy, a consideration, she had never known before. He made her feel precious and lovable... a creature to be adored and marveled over, above all a woman to be protected and treasured and made happy. . . . It was a mutual discovery. 1

This intimate contact of two vastly different cultures over a period of time was bound to have its effect in profound changes-changes that are still taking place in the family and in society at large.

$1_{\text {Pearl S. Buck, The People of Japan (New York: Simon and }}$ Schuster, 1966), p. 126. 
Another important and powerful influence effecting changes in the family and the traditional characteristics of the Japanese was the state of mind caused by the collapse of the government. The crushing military defeat, the disruption of normal life caused by many years of war, and the devastation of most of their larger cities, the crippling of their economy, the presence of an army of occupation, the enforced abandonment of militarism and many other major features of their way of 1 ife, and, most of all, the realization that Japan was not a divine land protected by the gods combined to prepare the Japanese for adaptation and change.

Al1 that they had believed in, all the old patterns of life, all their old religious beliefs, all the old traditional values seemed to be discredited by the loss of the war. The very foundations of their life were not only shaken but had seemingly disappeared. They were forced to begin again, to re-examine their way of life in a way they had never done before.

There was, of course, much spiritual confusion. For after long centuries of being accustomed to the rigid hierarchical roles inherent in their society with its close supervision and rigid patterns of thought, the Japanese now witnessed the collapse of their cherished world and its values. But for a remarkably resilient and adaptable people, this spiritual confusion became the starting point for a new way of life.

Large-scale industrialization, the renewed emphasis on capitalism, and urbanization are three closely related influences that have had a most marked effect in breaking up the old patterns 
of the traditional family. These trends seen to some extent since the turn of the century have gained momentum in the years since the war's end. "With this trend, the practice of colateral kin living together with lineal kin has by and large gone out of existence and the dōzoku (clan) system, on the basis of which the main family could expect cooperation of branch families in the same local community, has begun to disintegrate." 1

Conversely, industrialization and the move to the city has meant

- . an increase in the number of nuclear families, accompanied by the growth of a salaryman class. Today the nuclear family pattern is found in the salaryman class while the traditional ie (household) remains the pattern among the small independent businessmen in the professional class and among the farmers. 2

Still another influence on the breakup of the old family patterns and structure is the laws that have been enacted based on the new constitution and produced under the guidance of the occupation government. The land-reform measures, the new inheritance law, and the clarification of the status of women are some examples of the legal forces which have helped to change the family system.

Takahashi Koyama, professor of anthropology at Tokyo Municipal College, writing of the effects of the new constitution on the changing family structure, states:

$I_{\text {Takashi Koyama (of Tokyo University, formerly president of }}$ the Japan Sociological Society), Families in East and West, Reuben Hill and Rene Konig, eds. (The Hague, Netherlands: Mouton and Co., 1970), p. 318 .

2 Kazuko Matsuzawa, "Japanese Social Structure and the Status of Women," The Japan Christian Quarterly, Spring 1974, p. 75. 
The New Constitution, promulgated in 1946, set forth the principle of respect for individual dignity and equality of the sexes upon which to base the new family system. The traditional family system, collectivity oriented and patriarch-centered, was thereby deprived of its legal status and gave way before the new family law, which emphasizes the importance of a conjugal-unit-centered married life. In this way, the family system, which had been in a state of "cultural lag" since the emergence of a modernized Japan, now leaped into the leading position of social progress. 1 (Emphasis supplied)

However, as other Japanese writers point out, this U.S. sponsored constitution was not "natural law" for the Japanese people, who found it difficult to ignore centuries of culturally related values and practices. ${ }^{2}$ Thus in spite of the legal basis for change, the new freedoms and practices for the family did not develop overnight nor did they abruptly develop strong roots. In spite of the slow progress toward implementation of these legal changes, there has been a distinctly noticeable move toward a democratization of the family system in recent years. As Koyama states:

Even to reluctant people, it appears to be an inevitable process. The legal reform, as stated before, has had good affects upon the growth of the younger generation and the improvement of women's social position. What were once regarded as good morals and customs of Japan are now lost, but the contemporary Japanese is going to find a new pleasure in family life. 3

As has been pointed out, perhaps the most fundamental and far-reaching change brought about has been the emancipation of women.

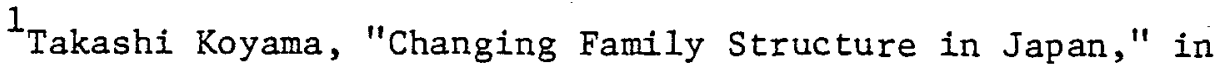
Japanese Culture, Its Development and Characteristics, edited by Robert J. Smith and Richard K. Beardsley (Chicago, Ill.: Aldine Publishing Co., 1962), p. 51 .

2 Kizaemon Ariga, Nihon no Kazoku (The Japanese Family) (Tokyo: Shibundo, 1965), p. 7 .

${ }^{3}$ Smith and Beardsley, Japanese Culture, Its Development and Characteristics, p. 54 . 
This is already beginning to have, and will increasingly have in the future, a profound effect upon the whole Japanese culture, for such a basic change--a veritable social revolution--not only effects the family structure and relationships but penetrates every field of social activity, economic, political, educational or others. 1

The New Constitution specifically stated that "a11 of the people are equal under the 1aw . . ." and that "marriage shall be based only on the mutual consent of both sexes and it shall be maintained through mutual cooperation with the equal rights of the husband and wife as a basis." 2

One more factor that has had an influence in molding the newly emerging family is the new and freer educational system. Chiye Sano, in dealing with the changing values of the institutional family, points out that:

Traditional values associated with the family system are getting less support from those with higher education than from those with less education. . . . The better-educated . . . are more sensitive to propaganda from the reformist circles attacking the abuses of the traditional family system. They are also better informed of the legal and other reforms instituted after the war. They have wider ranges of interest and activities than those confined to or centered around the family, so that they do not need to cling to the old traditional values for their psychological security. Above all, their general value orientation is more often individualistic and utilitarian, as well as rationalistic, which goes counter to the values emphasized in the traditional family system. 3

Since World War II the process of social and cultural change has continued to accelerate. The world has marveled at the speed

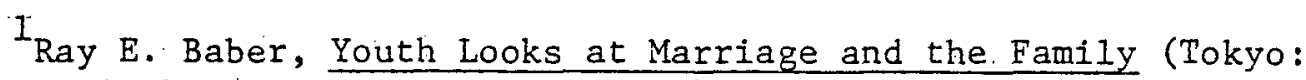
International Christian University, 1958), p. 11.

2 Ibid.

${ }^{3}$ Silberman, pp. 119, 120. Selected from Chiye Sano's book, Changing Values of the Institutional Family (Washington, D.C.: Catholic University Press, 1958), pp. 71-98, 118-130. 
with which the nation has recovered economically and has taken its place once again among the leading nations of the world. Japan now enjoys the most favorable economic condition of its entire modern history. And economic and material growth has been paralleled by change and development in the social and cultural life of the nation as well. One recent observer of the scene says, "Japan is in a state of cultural flux that might be called peaceful boiling. There is of course, continuity, but what describes today does not accurately describe tomorrow." 1

\section{Remnants of the Traditional Family Today}

As has been noted, the changes in Japanese society and culture since World War II have been sudden and dramatic. Perhaps nowhere in the world have the marriage and family patterns of a great culture been changing so radically and so rapidly. These changes, some voluntary and some involuntary, beginning as they did before the war but escalating suddenly'soon after the war's end, have produced a pattern of living which can best be described as "kaleidescopic." Good is mixed with bad, Western culture with Eastern, traditional with the new, all produce a "mixed bag" of changes.

Without a doubt, as sociologists, newspaper surveys, and contemporary historians have indicated, the structure and patterns of the old family system are rapidly giving way to the new. The traditional patriarchal family is disintegrating under the

\footnotetext{
${ }^{1}$ Norbeck, Changing Japan, pp. 2,3 .
} 
relentless pressures of the post-war era and its modern industrial society. The ie and dozoku systems, particularly in the city, are greatly weakened if not altogether absent.

Sentiment has grown against living with one's parents or parents-in-1aw after marriage. This is obvious not only in the city but even to some extent in the rural areas. Father's voice has lost a good deal of its authority, whereas mother's has gained. Younger sons are not at so great a disadvantage as formerly and brides have lost some of their meekness. The relationship between men and women in marriage is more equal and more intimate. Ancestor worship is losing ground and the old values of chügi (loyalty), giri (responsibility), and on (obligation) are not as strong as they once were.

And yet, as Takashi Koyama reminds us, it is rather a "crude generalization" to conclude that the emergence of the nuclear family in Japanese society means the complete disappearance of the old traditional family.

For, whereas the family composition is changed by the social system external to the family, intertwined with this change is one derived from the dynamics of the system internal to the family as such. . . We must bear in mind.. . that the complete transformation of the family system through all segments of Japanese society cannot be attained in a short time.1

Writing on social change and the individual, Kazuko Tsurumi speaks of the "persistence of residual affective postures and

${ }^{1}$ Smith and Beardsley, pp. 47-51. Article by Seiichi Kitano, Professor of Sociology, Osaka University. Dozoku and Ie in Japan: The Meaning of Family Genealogical Relationships. 
attitudes" in the ideology of the present Japanese. ${ }^{1}$ She points out that even though the over-all structure of Japanese society has changed from the communal-totalitarian type to the communal-mass type the basic communal pattern is perpetuated and "will remain dominant, at least among some part of the population" ${ }^{2}$ for some time to come.

Another Japanese writer, while noting the trend toward the nuclear family, believes that it would be misleading to take this to mean that "no particularism remains in Japan today." ${ }^{3}$ He states that just as Nobushige Hozumi the great scholar of the Meiji era pointed out, during that era

. . there was a transfer of the meaning of particularism for the individual from the unit of the family to the unit of the state, so today, in Japan, particularism in a new form of "family identification" may be seen in the labor movements, the business corporation, and the political organizations. . . .4

Beardsley, Hall, and Ward agree for they affirm that the trends toward the weakening of the old traditional family system and the emergence of the nuclear-conjugal family "does not of itself necessarily imply anything which can be called 'a triumph of individualism. $"{ }^{5}$ They also add that "attitudes of collectivityorientation" still survive in a new form. However, the process of

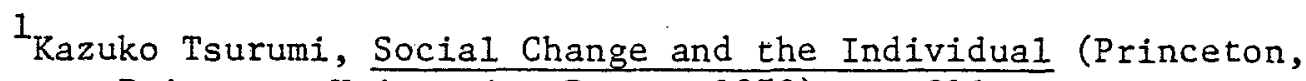
New Jersey: Princeton University Press, 1970), p. 212.

${ }^{2}$ Ibid.

${ }^{3}$ Aikawa and Leavenworth, Mind of Japan, p. 30.

${ }^{4}$ Ibid.

${ }^{5}$ Richard K. Beardsley, John W. Hall, and Robert E. Ward, The Household (Chicago: University of Chicago Press, 1959), reprinted in Silberman, p. 184. 
moving from the collective to the individual frame of reference is proceeding as the individual's involvement in education, employment, recreation, and political activity become increasingly divorced from the household.

This "residual affective posture and attitude" of the old family ideology in its "new form of family identification" can be seen in many. areas of Japanese society today. "Japanese business firms, government bureaus, and many universities and schools are organized in ways reminiscent of this familial model; [and] their organization may be more closely related historically to feudal or lord-vassal principles."I In such relationships the employee and the employer, the chief and the underling, the teacher and the pupil, and the religious leader and the parishoner play out the ancient roles which proscribe specific rights and duties and in which the superior occupies a paternalistic and authoritarian part.

Two terms still in common use give evidence of this ancient traditional attitude toward roles and relationships in modern society. One of these is the word sensei, meaning "teacher" or "mentor," but its wide application to people outside the teaching profession suggests "its connotation of benevolent but stern authority and superiority." 2 The other is the dual-term oyabun-kobun ("parentstatus" or "parent surrogate" and "child status"). This expression is often applied to any highly paternalistic relationship indicating a "very close tie between status and role," ${ }^{3}$ similar to that in

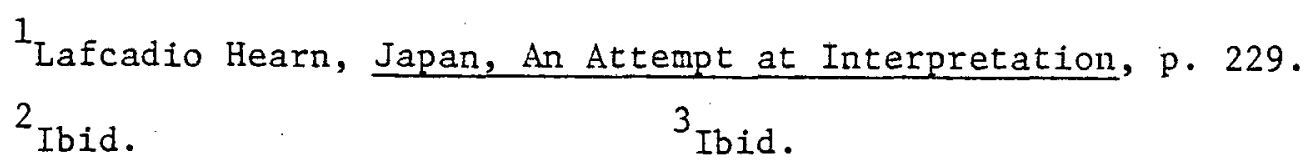


the traditional family system. The following observation by Edward Norbeck in his book Changing Japan speaks to this point:

Industrial and commercial concerns are heavily paternalistic, looking into and after the welfare of their personnel in ways that go far beyond the demand of coldly rational business. Thus the firm takes on many of the aspects of family enterprise. -. Today, the oyabun-kobun relationship in its old form is common only at the fringes of society, in the world of professional criminals and prostitutes, where the economic innovations connected with legal employment have not penetrated. -. In the world of the law abiding citizens, the formal oyabun-kobun has generally been transmitted into milder forms of paternalism and these permeate Japanese society. I (Emphasis supplied)

Although progressive elements of society continue to cry out against these remnants of the feudalistic family system in modern society and to call for the rewarding of personal initiative and ability instead, still no segment of Japanese society may be described as entirely free of familism, as is evident in labor unions, the relationship of professors to disciples, and business and society at large.

Nakane's outstanding work on the structure of Japanese society clearly points out ${ }^{2}$ that the modern industrial enterprise reveals the same basic structural characteristics as were seen in the traditional Japanese family; that is, the corporateness of the organizational goals and the vertical human relations within the group. This is indicated by terms in common use today by "salarymen" who speak of "uchi no kaisha" (my company) as opposed to "otaku no kaisha" (your company). Here the implication of the word

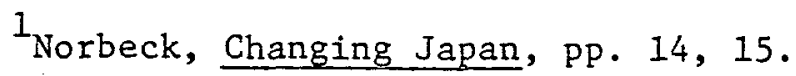

${ }^{2}$ Chie Nakane, Japanese Society (Berkeley, Calif.: University of California Press, 1972), p. 32 . 
uchi, which means "my house or home," is significant. Rather than a contractual relationship, the salaryman places himself in a childparent relationship to his company. He pledges loyalty and in return gets security and protection, often on a life-time employment basis.

In the newly emerging nuclear family itself, remnants of the old patterns of thinking and behavior are still evident in spite of impressive changes. One Japanese scholar refers to the newly developing family as "nuclear fission of the family system," although he questions to what extent real breaking away from the old system will take place. He also believes that "whatever change the function of the family system may undergo, kinship relationships seem to continue in existence."

Although arranged marriages in the strictest sense of the term are not common today, "many parents still wish to control the marriages of their children to some extent," according to a recent survey, "but they think of this control as necessary for the child's own good, not for the good of the 'family'." 2 And still, even if only for the sake of form, a nakodo (go-between) often has a part in the marriage ceremony today. This attitude toward the old marriage and family values is further pointed out by Chiye Sano in the following quotation:

The majority of Japanese parents still attach considerable value to the institutional family as a mechanism for regulating the relationships between different generations, and guaranteeing p. 319 .

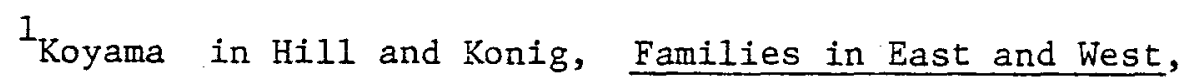
2 Beardsley; Hall and Ward, p. 172. 
unity and harmony in the family, and security for individual members thereof. The formal or nominal institutional features, such as perpetuation of the family name are being less emphasized, but the central values, such as parental responsibility for marriage, are still being endorsed. 1

In spite of the great changes that have taken place and that are continuing to be made in the Japanese family, much of the old still remains. Perhaps the Biblical phrase may be turned around to describe the emerging family system as "old wine in new bottles." And even closer to the truth one could probably say that what is emerging is neither Eastern nor Western but is in keeping with the resilience and adaptability of the Japanese people, a new creation which may in time become a product superior to either. However, until that new creation is a completed reality, the Japanese family continues to suffer growing pains. Matsubara, in Gendai no Kazoku (The Modern Family), says ${ }^{2}$ that the Japanese family today can be characterized by three "lacks": (1) fuzoku, or lack of material needs, (2) fuman, or lack of satisfactions, thus frustrations, and (3) fuan, or lack of peace and happiness, thus insecurity, fear.

Perhaps the greatest lack of the family today, however, goes deeper than these three to a basic lack of understanding as to the meaning of life, to an uncertainty as to personal and family goals. Because of the loss of faith in their traditional beliefs and values, their inner life has too often become more and more insecure. Many Japanese today, under the pressures of urban living with its

${ }^{1}$ Sano Chiye in Silberman, p. 131.

2 Haruo Matsubara, Gendai no Kazoku (The Modern Family) (Tokyo: Nihon Keizai Shimbunsha, 1964), p. 180. 
loneliness and separation from family support and fellowship, long for friendship, for a sense of belonging, and for unchanging values and goals.

The Japanese Adventist family is unquestionably both Christian and Japanese. Chapters II and III have been a review of the literature concerning the traditional Japanese family in an attempt to better understand the cultural roots of the Adventist family. In chapters $V$ through IX an attempt will be made to discover the Adventist family as it exists today. By means of this two-fold approach to this study, it is hoped that a true picture will emerge of the Seventh-day Adventist family in Japan today. 


\section{CHAPTER IV}

\section{SURVEYING THE ADVENTIST FAMILY IN JAPAN}

\section{Research Design}

The first Seventh-day Adventist Japanese family was established around the turn of the century when Teruhika Okohira, the first Japanese church member and the first Japanese denominational employee, married Miss Aiko O.gata, one of his early converts. This marriage took place a short time after Okohira and W. C. Granger arrived in Yokohama in 1896 to preach the gospel. By the end of 1975 the number of Adventists had grown to more than 8,000 and the number of Adventist families approached one thousand.

The purpose of this study was to gain a clearer understanding of the Adventist family in Japan. This study was initiated by the writer's desire to see the Adventist family strengthened to become an active agency in reaching out in love and understanding to lead non-Christian friends and relatives to Christ. This chapter presents a description of the research design, instrumentation, data collection, limitations, and the treatment of the data.

In order to obtain the information needed to form a comprehensive understanding of the Adventist Japanese family, several background areas were studied. First, since the Adventist family in Japan functions in a Japanese setting, a review of literature on 
the cultural background of the Japanese family was undertaken in chapters II and III.

The literature review attempted to lay a foundation for understanding the cultural background and the typical characteristics of the Japanese family, and to view the family in the light of past history and recent changes and developments. Then a series of instruments was designed and administered to Adventist church members and leaders in order to formulate a clear description of the family as it exists today. The instruments used were as follows: The Adventist Family Survey, The Divided Family Survey, The Unmarried Young People's Survey, The Ministers' Survey, and The Membership Faithfulness Survey.

\section{Instrumentation}

The instruments used were designed to formulate an understanding of the family by viewing it from several angles. Following is a brief description of the various instruments. ${ }^{1}$

The Seventh-day Adventist Family Survey

The Adventist Family Survey was the primary survey instrument. It consisted of sixty-three questions divided into five categories. The five categories sought information concerning: (1) biographical backgrounds, (2) children, (3) religion in the home, (4) happiness and stability of the home, and (5) dynamics and miscellaneous items in the home. This survey was sent to the

$1_{A}$ translation of each survey instrument, along with a letter of explanation is provided in the appendix. 
total population under study, that is, to all united Adventist families in Japan. United Adventist families in this study refers to those families in which both marriage partners are listed on church records as members of the Seventh-day Adventist church.

The Divided Family Survey

The Divided Family Survey instrument was identical to the Adventist Family Survey, except that two questions were added which applied solely to families in which one of the spouses was not a member of the church. It was designed to secure information that would show similarities and differences between the divided families and the united families. This instrument was administered only to a sample of divided families.

The Unmarried Young People's Survey

The Unmarried Young People's Survey contained eighteen questions and was administered to Adventist young people between the ages of 18 and 35 . It was designed to ascertain their attitudes toward Christian marriage and family related problems and to solicit their suggestions as to how best to encourage the formation of Adventist homes. A sample of youth were surveyed with this instrument.

The Seventh-day Adventist Ministers' Survey

The Adventist Ministers' Survey instrument was designed for ordained and licensed Adventist ministers in Japan. It consisted of fourteen questions which were designed to obtain information concerning the ministers' specialized training for ministering to 
families, their interest and involvement in family education and counseling, their evaluation of problem areas in Adventist families, and their suggestions as to how best to engage in family evangelism. It was administered to the total population, that is, to all 108 ordained and licensed ministers.

\section{The Membership Faithfulness Survey}

The Membership Faithfulness Survey instrument attempted to obtain data on the faithfulness of the church members, based on variables of sex and family relatedness. It was sent for evaluation, to selected pastors from each of the six districts of the Adventist church in Japan in order to gain an accurate representation of the faithfulness of the members of large and small churches as well as institutional churches. The degree of faithfulness was divided into three categories: (1) faithful--those who attend church services regularly when possible and participate in and support the church by word, action, and offerings; (2) lukewarm--those who attend church services infrequently and who fail to support the church on a regular basis; and (3) backslidden--those who never attend church services and who fail to support the church by word, action, or offerings.

\section{Data Collection}

A list of all organized churches and companies in Japan, along with the names and addresses of the pastors, was obtained from the secretarial office of the Japan Union Mission of Seventhday Adventists with headquarters at 846 Kamikawai-machi, Asahi-ku, 
Yokohama, Japan. Responses from all the leaders of the eighty-one churches and thirty companies resulted in the formation of a master list of names and addresses of the 935 Adventist families on church membership records, as of September 30, 1975. This does not include the overseas missionary or the American Armed Forces families who are members of the church.

Two copies of the Seventh-day Adventist Family Survey, a blue one to be filled out by the husband and a pink one by the wife, were sent to each family on the list. These questionnaires, along with a self-addressed, stamped envelope, were sent out during the months of November and December 1975. A reminder post card was sent out to those who did not respond to the initial request.

Tabulation of the total responses received from this primary survey instrument can be seen in table 1 . Of the 1,870 questionnaires sent out, 1,155 , or 62 percent of the total, were returned in useable form. The Conference Church is composed of members living in areas far removed from an organized church or company. Although membership records of the Conference Church are kept at the headquarters office in Yokohama, the members are scattered throughout the territory of the six organized districts and responses received from among these members have been reported accordingly. A high of 81 percent of the questionnaires were returned from Hokkaido, perhaps due to the fact that the researcher served for eleven years on that northernmost island and was personally acquainted with nearly all of the members. A low of 56 percent of the questionnaires was returned from the Tohoku district. 
TABLE 1

SEVENTH-DAY ADVENTIST FAMILY SURVEY RESPONSE

\begin{tabular}{lccccc}
\hline District & $\begin{array}{c}\text { Church } \\
\text { Member- } \\
\text { ship }\end{array}$ & $\begin{array}{c}\text { Number of } \\
\text { Families }\end{array}$ & $\begin{array}{c}\text { Question- } \\
\text { naires } \\
\text { Sent Out }\end{array}$ & $\begin{array}{c}\text { Responses } \\
\text { Received }\end{array}$ & $\begin{array}{c}\text { Percent- } \\
\text { age of } \\
\text { Total }\end{array}$ \\
\hline Hokkaido & 285 & 42 & 84 & 68 & 81 \\
Tohoku & 238 & 40 & 80 & 45 & 56 \\
Kanto & 3544 & 450 & 900 & 540 & 60 \\
Chubu & 1097 & 175 & 350 & 231 & 66 \\
Nishi-Nihon & 1170 & 146 & 292 & 178 & 61 \\
$\begin{array}{l}\text { Okinawa } \\
\text { Conference } \\
\text { Church }\end{array}$ & 1001 & 82 & 164 & 93 & 57 \\
\hline \begin{tabular}{l} 
Total \\
\hline
\end{tabular} & 8062 & 935 & 1870 & 1155 & 62 \\
\hline
\end{tabular}

It was assumed that the non-respondents were largely among the lukewarm and backslidden church members. However, the researcher is aware of at least a few among the faithful church members who failed to return the completed questionnaires. Perhaps it was their position in the church or their close acquaintance with the researcher which caused some hesitancy in filling out questionnaires which dealt with personal matters. As the estimated percentage of faithful church members was seen to be just a little over fifty percent, the respondents must have included not only faithful members but also lukewarm and backslidden members as well. Just what percentage of the respondents were in each category is not known. 
An examination of the number of responses received indicates that there was a satisfactory response from each of the six districts and that there were some responses from each church and company in Japan. The 1,155 responses, or 62 percent of the total questionnaires sent out, were regarded as adequate in the light of the data which indicated that 66.5 percent of the total church membership gave some support to the church and 33.4 percent failed to support the church in any way. Thus, the responses received would seem to constitute an adequate representation of the active Adventist family membership.

The Divided Family Survey instrument administered to the Adventist spouses of divided families was not sent directly to the individuals. Instead, a limited number were sent to the district pastors of each district for distribution to divided family spouses in the churches within their districts. A total of eighty-one completed questionnaires, representing an available sample of divided families in each district, were returned. These were compared with those received from families in which both the husband and the wife were both church members to discover the problems and tensions at work in these divided families.

Table 2 indicates that unmarried young people from each of the districts completed the Unmarried Young People's Survey although the ratio of the number of completed forms to the membership of each district was not entirely the same. The questionnaires were sent to the district pastors for distribution to youth in the churches of the district, with the exception of 
TABLE 2

UNMARRIED YOUNG PEOPLE'S SURVEY RESPONSE

\begin{tabular}{lcccc}
\hline \hline District & $\begin{array}{c}\text { Church } \\
\text { Member- } \\
\text { ship }\end{array}$ & $\begin{array}{c}\text { Percentage } \\
\text { of Total } \\
\text { Member- } \\
\text { ship }\end{array}$ & $\begin{array}{c}\text { Number of } \\
\text { Responses }\end{array}$ & $\begin{array}{c}\text { Percentage } \\
\text { of Total } \\
\text { Responses }\end{array}$ \\
\hline Hokkaido & 285 & 3.9 & 26 & 13.5 \\
Tohoku & 238 & 3.2 & 8 & 4.2 \\
Kanto & 3544 & 48.3 & 50 & 26.0 \\
Chubu & 1097 & 15.0 & 48 & 25.0 \\
Nishi-Nihon & 1170 & 16.0 & 47 & 24.5 \\
Okinawa & 1001 & 13.6 & 13 & 6.8 \\
Conference & & & & 100.0 \\
Church & 727 & 100.0 & 192 & \\
\hline TOTAL & 8062 & & & \\
\hline
\end{tabular}

Hokkaido where the writer personally delivered the questionnaires to the pastors of each church for distribution. Thus, again, an available sample was used. This partially explains the comparatively large number of completed questionnaires from Hokkaido.

The Ministers' Survey was sent to all ordained and licensed ministers whose names and addresses were received from the secretarial office of the Japan Union Mission of Seventh-day Adventists at the Yokohama headquarters. A letter of explanation, the survey instrument, and a self-addressed stamped envelope were sent to each of these men. A month after the questionnaires were sent out a reminder post card was sent to those who had not yet responded to the initial request. 
The final total response to the Ministers' Survey indicated that of the 108 ministers,"seventy-six ' active and eight retired ordained ministers and twenty-four licensed ministers, ninety-nine individuals, which represents a 91.7 percent response, completed and returned the questionnaires.

Data for the Membership Faithfulness Survey was collected with the cooperation of ministers from ten churches representing each of the six districts. These ten churches were selected as representative churches from among large and small, rural and urban churches as we11 as an institutional church. A special blank to be filled out by each pastor concerning the degree of faithfulness of each member listed on his church membership records, along with instructions explaining the purpose of the survey and asking for their cooperation, was; sent to these pastors:

As a result of personal contact, phone calls, and letters of reminder, one hundred percent returns from the selected ministers was received. The ministers' evaluation of the faithfulness of the members of these ten representative churches, representing 22 percent of the total church membership and 26.7 percent of the united families in the Adventist church in Japan, gives an adequate representation of the degree of membership faithfulness of the Seventh-day Adventist Church as a whole.

\section{Limitations}

A number of limitations concerning the various survey instruments used have been perceived. One of these in particular concerns the personal nature of some of the questions in the 
Adventist Family Survey. Although an attempt was made to assure the respondents of the confidential nature of the research, the fact that each questionnaire carried a five-digit identification number no doubt prevented some members from filling out and returning the questionnaire and produced less than completely honest answers on the part of other members. Phone calls, notes added at the bottom of questionnaires, and letters indicated that a number of the Adventist spouses surveyed were hesitant to cooperate completely. Leaving off the identification numbers might have been advisable, however the number did enable the researcher to know which questionnaires were still outstanding. Reminder post cards sent to these individuals resulted in the return of several hundred additional completed surveys.

Another limitation affecting the accuracy of this study of the Adventist family in Japan can be seen in the nature of the respondents. Although questionnaires were sent to al1 1,870 spouses of united Adventist families, it is assumed that the percentage of loyal, faithful church members completing the survey. was significantly higher than that of inactive and apostate members. In the case of the survey instruments sent to spouses of divided homes, as well as those sent to unmarried Adventist youth, it is likely that since these were distributed to those who were in attendance at the church service, the responses reflect largely the situation and opinions of faithful church members. The size of the available sample, especially in the case of responses from spouses of divided homes, would also have a bearing on the accuracy of the report. 
Still another limitation was felt in the insufficient explanation and unclear nature of some of the questions which made it difficult for the respondent to answer those questions intelligently. This was partly the result of taking too much for granted and partly due to problems encountered when translating the survey instrument into Japanese. In the case of some questions, it would have been simpler if there had been fewer categories of responses. Moreover, it would have been advantageous if more care had been used to arrange the categories of responses to certain questions so that there would be a similar spread in ages, length of marriage, number of children, and so forth. For purposes of comparing the responses from single youth, Adventist ministers, and spouses of Adventist families to similar questions asked of each group, the wording and form of the questions in the various questionnaires should have been more similar.

Respondents were asked to circle one choice of possible responses presented. This system was chosen as the most familiar to those filling out the questionnaires and the least likely to induce error. However, transferring the data from the various questionnaires to the computer cards proved very time-consuming and increased the potential for error. Some simpler system would have been desirable.

Another limitation can possibly be noted in the number and extent of the various survey instruments used. Although these were valuable in adding breadth of knowledge to the study, they had a tendency to limit the study in certain areas. Follow-up 
questions would have given greater depth and insights into certain aspects of the family.

\section{Treatment of Data}

The data received from each of the various survey instruments, with the exception of the Membership Faithfulness Survey, were manually transferred to computer cards. These were processed through a computer and print-outs were produced. Selected variables which seemed to be most pertinent to the objective of this research project were also analyzed. Two types of tables were prepared presenting the data from the print-outs. One type simply recorded the totals of the various responses to a given question. The other type presented data and analyzed it according to certain variables, such as the age and sex of the respondent, the length of marriage, Adventist background, employment category of the marriage partner, and the degree of perceived happiness in the family. These were recorded according to the number of responses, the percentages of the total responses, and mean percentages.

\section{Summary}

This chapter has been concerned with the design and procedures for executing the study. Included were descriptions of the research design for the overall study, as well as for the questionnaires themselves, the instrumentation used, the collection of various kinds of data, the limitations of the procedures used, and the treatment of the data. The remaining chapters present the data in tabular and descriptive form and include a brief 
analysis of the significance and insights, recommendations and conclusions drawn from this research. 


\section{CHAPTER V}

FAMILY BIOGRAPHICAL DATA

The primary survey instrument used in this research project was the Adventist Family Survey, consisting of sixty-three questions divided into five categories. Chapters V through IX and XII present the data collected from the responses to the forty-seven questions especially significant to this study.

The tables in this and the following chapters consist of cumulative responses to these questions, and, in some cases, comparisons with certain sub-populations, such as classifications according to sex, age, length of marriage, and employment categories are also included. Similarities and differences in the data received from divided families will be noted from time to time. Also, where pertinent, responses from married young people and from Adventist ministers will be compared to those of united families. Where available comparable figures will be cited from the Japanese family in society at large.

\section{Age of Respondents}

Table 3 indicates the ages of both husbands and wives among Adventist families. This table indicates that 62 percent of the husbands and 56.1 percent of the wives who responded were forty years of age or older, and 20.1 percent of the husbands and 13.0 percent of the wives were in the bracket of sixty years of age or over. 
TABLE 3

AGE CATEGORIES OF ADVENTIST SPOUSES

\begin{tabular}{|c|c|c|c|c|}
\hline \multirow{2}{*}{$\begin{array}{c}\text { Age } \\
\text { Categories }\end{array}$} & \multicolumn{2}{|c|}{ Husbands } & \multicolumn{2}{|c|}{ Wives } \\
\hline & $\begin{array}{c}\text { Total } \\
\text { Responses }\end{array}$ & $\begin{array}{c}\text { Percentage } \\
\text { of Total }\end{array}$ & $\begin{array}{c}\text { Total } \\
\text { Responses }\end{array}$ & $\begin{array}{c}\text { Percentage } \\
\text { of Total }\end{array}$ \\
\hline Under 24 years of age & 7 & 1.2 & 11 & 6.1 \\
\hline $25-29$ years of age & 39 & 6.7 & 63 & 10.1 \\
\hline $30-34$ years of age & 92 & 15.9 & 89 & 15.4 \\
\hline $35-39$ years of age & 82 & 14.2 & 90 & 15.6 \\
\hline $40-49$ years of age & 153 & 26.5 & 152 & 26.3 \\
\hline 50-59 years of age & 89 & 15.4 & 97 & 16.8 \\
\hline 60 years of age or over & 116 & 20.1 & 75 & 13.0 \\
\hline TOTAL & 578 & 100.0 & 577 & 100.0 \\
\hline
\end{tabular}

Although equivalent figures for age categories of husbands and wives in the population of Japan at large are not available, census figures for 1974 show that 34 percent of the population was over forty years of age, and that 12 percent were sixty years of age or over. ${ }^{1}$

These figures indicate that either the mean age of Adventist husbands and wives was greater than that of the population at large or that younger Adventist spouses refrained from completing the survey instrument in greater numbers than did older ones. It is conjectured that both of the above possibilities may be true.

${ }^{1}$ Japan Statistical Yearbook (Tokyo: Japan Statistical Association, July 15, 1976), PP. 24, 25. 


\section{Length of Marriage}

When asked the question, "How long have you been married to your present spouse?" 6.1 percent answered "less than two years," and 13.8 percent responded "more than 35 years." As table 4 shows, over 50 percent of the respondents had been married more than fifteen years. These figures would seem.to confirm the impression gained in analyzing the age categories above, that a larger percentage of older spouses completed the questionnaire than did younger ones or that there are more older couples in the Seventh-day Adventist Church.

TABLE 4

LENGTH OF PRESENT MARRIAGE

\begin{tabular}{lcc}
\hline $\begin{array}{c}\text { Length of Marriage } \\
\text { Categories }\end{array}$ & Number of Responses & Percentage of Total \\
\hline Less than 2 years & 70 & 6.1 \\
$2-5$ years & 129 & 11.2 \\
$6-9$ years & 180 & 15.6 \\
$10-14$ years & 189 & 16.4 \\
$15-24$ years & 265 & 22.9 \\
$25-34$ years & 163 & 14.1 \\
35 years or more & 159 & 13.8 \\
\hline TOTAL & 1155 & 100.1 \\
\hline
\end{tabular}




\section{Age Differential of Spouses}

There was a slight discrepancy in the responses recorded by husbands and wives. Speculating that women are generally more conscious of such matters, and thus more nearly accurate, table 5 records the wives' responses. As might be expected, the number of husbands whose age was greater than that of their wives was considerably larger than the number of wives whose age was greater than that of their husbands. About one out of ten of the respondents indicated that his/her age was the same as that of his/her spouse's.

\section{TABLE 5}

AGE DIFFERENTIAL OF HUSBANDS AND WIVES

\begin{tabular}{lcc}
\hline $\begin{array}{c}\text { Categories of Age } \\
\text { Differential }\end{array}$ & Number of Responses & Percentage of Total \\
\hline Husbard, 1-2 yrs older & 107 & 18.6 \\
Husband, 3-5 yrs older & 157 & 27.4 \\
Husband, 6-9 yrs older & 109 & 19.0 \\
$\begin{array}{l}\text { Husband, more than } \\
\text { 10 yrs older }\end{array}$ & 19 & 3.3 \\
$\begin{array}{l}\text { Wife, 1-2 yrs older } \\
\text { Wife, 3-5 yrs older }\end{array}$ & 68 & 11.8 \\
Wife, 6-9 yrs older & 37 & 6.4 \\
Wife, more than \\
$\begin{array}{l}\text { 10 yrs older } \\
\text { Husband and wife the } \\
\text { same age }\end{array}$
\end{tabular}


What effect, if any, the age differential had on the stability and happiness of the marriage can be noted by examining table 71 which deals with the marriage partners' evaluation of their own marriage happiness.

A study of table 6 and figure 1 indicates that there was a marked difference in the age differential of younger couples as compared to older ones. Whereas only 16.7 percent of the women twenty-four years of age or less were older than their husbands, 55.5 percent of those sixty years of age or over were older. Also, as compared to older couples, the younger ones by a wide margin preferred marriages in which the husband was older than the wife. The decline in percentages of the spouses of Adventist families who married partners that were the same age as themselves was quite noticeable. Whereas 22.2 percent of marriage partners who were twenty-four years of age or under married spouses the same age as themselves, only 3.1 percent of those sixty years of age or over did so.

Part of what this change might signify can be seen by comparing these figures with those in table 7. A larger percentage of the younger spouses and those who chose their own marriage partner tended to choose partners nearer their own age than did older ones or those whose marriage was arranged by their parents or a "go-between." Younger couples also placed considerably less emphasis on which spouse was the older. The percentage of marriages in which the husband was older decreased from 58.5 percent among those in which the parents arranged the marriage to 44.8 percent 
TABLE 6

AGE DIFFERENTIAL OF HUSBANDS AND WIVES BY AGE CATEGORIES OF RESPONDENTS

\begin{tabular}{|c|c|c|c|c|c|c|c|c|c|c|}
\hline \multirow{2}{*}{$\begin{array}{c}\text { Age } \\
\text { Categories }\end{array}$} & \multirow{2}{*}{$\begin{array}{c}\text { Total } \\
\text { Responses }\end{array}$} & \multicolumn{4}{|c|}{$\begin{array}{l}\text { Percentages of } \\
\text { Husbands Older than } \\
\text { Their Wives }\end{array}$} & \multicolumn{4}{|c|}{$\begin{array}{l}\text { Percentages of } \\
\text { Wives O1der than } \\
\text { Their Husbands }\end{array}$} & \multirow{2}{*}{$\begin{array}{l}\text { Percentage of } \\
\text { Husbands and } \\
\text { Wives who were } \\
\text { the Same Age }\end{array}$} \\
\hline & & $\begin{array}{l}1-2 \\
\text { yrs }\end{array}$ & $\begin{array}{l}3-5 \\
\text { yrs }\end{array}$ & $\begin{array}{l}6-9 \\
\text { yrs }\end{array}$ & $\begin{array}{l}\text { more } \\
\text { yrs }\end{array}$ & $\begin{array}{l}1-2 \\
\text { yrs }\end{array}$ & $\begin{array}{l}3-5 \\
\text { yrs }\end{array}$ & $\begin{array}{l}6-9 \\
\text { yrs }\end{array}$ & $\begin{array}{l}\text { more } \\
\text { yrs }\end{array}$ & \\
\hline 24 or under & 18 & 22.2 & 27.8 & 11.1 & --- & 16.7 & --- & --- & -- & 22.2 \\
\hline $25-29$ & 102 & 18.6 & 22.5 & 16.7 & -- & 15.7 & 7.8 & 1.0 & --- & 17.6 \\
\hline $30-34$ & 181 & 19.9 & 15.5 & 7.7 & 1.1 & 14.9 & 18.8 & 5.0 & $-\cdots$ & 17.1 \\
\hline $35-39$ & 172 & 18.0 & 19.8 & 10.5 & 2.3 & 17.4 & 16.3 & 7.6 & --- & 8.1 \\
\hline $40-49$ & 305 & 17.0 & 17.4 & 10.5 & .7 & 13.8 & 17.7 & 13.4 & 1.0 & 8.5 \\
\hline $50-59$ & 186 & 14.0 & 15.6 & 11.8 & 4.8 & 15.6 & 17.7 & 10.8 & 2.2 & 7.5 \\
\hline 60 or over & 191 & 9.9 & 12.0 & 15.7 & 3.7 & 9.9 & 17.3 & 21.5 & 6.8 & 3.1 \\
\hline TOTAL & 1151 & & & & & & & & & \\
\hline MEAN PERCENTAGE & & 16.2 & 16.9 & 11.5 & 2.1 & 14.4 & 16.5 & 10.8 & 1.7 & 9.8 \\
\hline
\end{tabular}




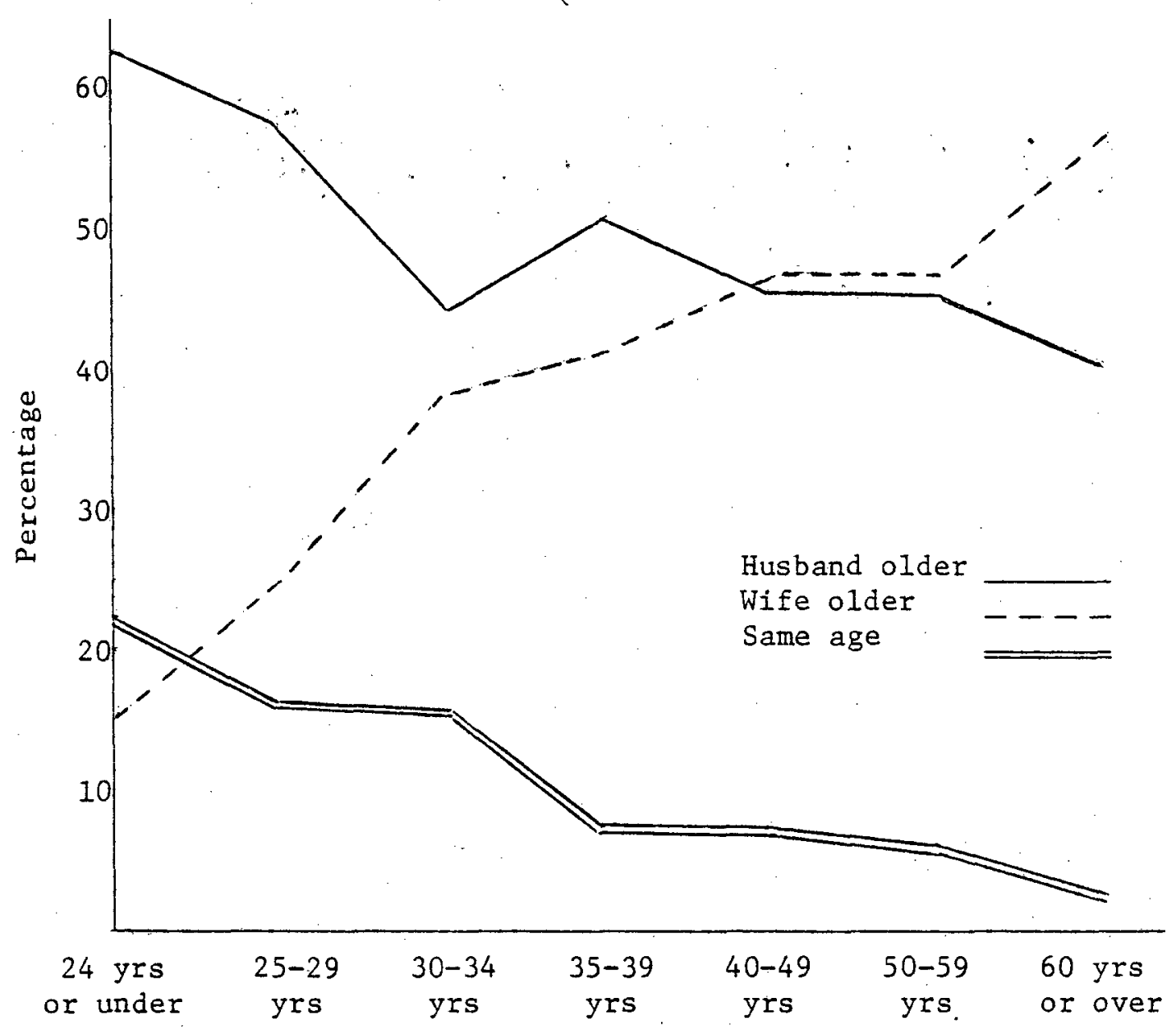

Fig. 1. Age differential of husbands and wives by age categories. 
TABLE 7

CORRELATION BETWEEN THE AGE DIFFERENTIAL OF HUSBANDS AND WIVES AND THE METHODS OF CHOOSING MARRIAGE PARTNERS

\begin{tabular}{|c|c|c|c|c|c|c|c|c|c|c|}
\hline \multirow{2}{*}{$\begin{array}{l}\text { Method of } \\
\text { Choosing } \\
\text { Marriage } \\
\text { Partners }\end{array}$} & \multirow{2}{*}{$\begin{array}{c}\text { Total } \\
\text { Responses }\end{array}$} & \multicolumn{4}{|c|}{$\begin{array}{c}\text { Percentages of } \\
\text { Husbands Older than } \\
\text { Their Wives }\end{array}$} & \multicolumn{4}{|c|}{$\begin{array}{l}\text { Percentages of } \\
\text { Wives Older than } \\
\text { Their Husbands }\end{array}$} & \multirow{2}{*}{$\begin{array}{l}\text { Percentage of } \\
\text { Husbands and } \\
\text { Wives who were } \\
\text { the Same Age }\end{array}$} \\
\hline & & $\begin{array}{l}1-2 \\
\text { yrs }\end{array}$ & $\begin{array}{l}3-5 \\
\text { yrs }\end{array}$ & $\begin{array}{l}6-9 \\
\text { yrs }\end{array}$ & $\begin{array}{l}10 \text { or } \\
\text { more } \\
\text { yrs }\end{array}$ & $\begin{array}{l}1-2 \\
\text { yrs }\end{array}$ & $\begin{array}{l}3-5 \\
\text { yrs }\end{array}$ & $\begin{array}{l}6-9 \\
\text { yrs }\end{array}$ & $\begin{array}{l}10 \text { or } \\
\text { more } \\
\text { yrs }\end{array}$ & \\
\hline Parents' choice & 94 & 16.0 & 19.1 & 19.1 & 4.3 & 12.8 & 12.8 & 7.4 & 2.1 & 6.4 \\
\hline Own choice & 940 & 16.1 & 16.8 & 10.0 & 1.9 & 14.3 & 17.4 & 11.1 & 1.6 & 10.6 \\
\hline other & 99 & 19.2 & 14.1 & 16.2 & 1.0 & 18.2 & 11.1 & 11.1 & 2.0 & 7.1 \\
\hline No answer & 22 & 9.1 & 22.7 & 22.7 & 4.5 & 9.1 & 13.6 & 13.6 & 4.5 & 0.0 \\
\hline TOTAL & 1155 & & & & & & & & & \\
\hline MEAN PERCENTAGE & & 16.2 & 16.9 & 11.5 & 2.1 & 14.4 & 16.5 & 10.8 & 1.7 & 9.8 \\
\hline
\end{tabular}


in marriages arranged by the couples themselves. This figure is almost identical with the percentage of self-arranged marriages in which the wife was older. This would seem to indicate that among couples who made their own marriage arrangements there was little difference as to which partner was the older.

\section{Marriage Status}

Table 8 indicates that at the time of the survey Adventist family respondents replied that 91.3 percent of all the husbands and 95.8 percent of all the wives were still married to their first and only marriage partner. Those who had remarried, either because of the death of their spouse or after divorce, numbered considerably more for husbands, 8.3 percent, than for wives, 3.5 percent.

TABLE 8

MARRIAGE STATUS

\begin{tabular}{|c|c|c|c|c|}
\hline \multirow{2}{*}{$\begin{array}{l}\text { Marriage } \\
\text { Status by } \\
\text { Categories }\end{array}$} & \multicolumn{2}{|c|}{ Husbands' responses } & \multicolumn{2}{|c|}{ Wives' responses } \\
\hline & $\begin{array}{c}\text { Total } \\
\text { Responses }\end{array}$ & $\begin{array}{l}\text { Percent } \\
\text { of Total }\end{array}$ & $\begin{array}{c}\text { Total } \\
\text { Responses }\end{array}$ & $\begin{array}{l}\text { Percent } \\
\text { of Total }\end{array}$ \\
\hline Once married & 528 & 91.3 & 550 & 95.8 \\
\hline $\begin{array}{l}\text { Spouse died-- } \\
\text { remarried }\end{array}$ & 27 & 4.7 & 9 & 1.6 \\
\hline $\begin{array}{l}\text { Divorced-- } \\
\text { remarried }\end{array}$ & 21 & 3.6 & 11 & 1.9 \\
\hline No answer & 2 & .3 & 4 & .7 \\
\hline TOTAL & 578 & 99.9 & 574 & 100.0 \\
\hline
\end{tabular}


According to census bureau statistics, ${ }^{1}$ there were 113,622 divorces and 1,000,455 marriages in 1975 in Japan as a whole. Thus for every one hundred marriages 11.36 ended in divorce. Divorce statistics in Japan have shown an increase from year to year. In comparison to these figures, Adventist couples show a very low number of divorces. However, statistics in this research do not indicate whether church membership preceeded or followed the divorce, or how many church members have been divorced and as a result have left the church or become inactive. This would be a fruitful area for further research.

\section{Method of Choosing Marriage Partner}

One of the characteristics of the traditional family in Japan was the method by which marriage partners were chosen. Marriages were arranged from the viewpoint of and primarily for the advantage of the family. Changes in this characteristic of Japanese marriage' have been noted by historians and sociologists. The rate of change has greatly accelerated in the years since World War II and especially during the past two decades.

Table 9 records the method by which marriage partners were chosen in united Adventist homes and compares this data with data from divided families. It will be noted that the percentage of parent-arranged marriages was much greater in divided families, 19.8 percent, as compared to 8.1 percent in united families. This seems to indicate that many of the Adventist spouses of these divided homes entered into marriage with a non-member, not by choice, but because of the pressure from parents. 
TABLE 9

METHOD OF CHOOSING MARRIAGE PARTNER

\begin{tabular}{|c|c|c|c|c|}
\hline \multirow{2}{*}{$\begin{array}{l}\text { Categories } \\
\text { of Method }\end{array}$} & \multicolumn{2}{|c|}{ United Families } & \multicolumn{2}{|c|}{ Divided Families } \\
\hline & $\begin{array}{c}\text { Total } \\
\text { Responses }\end{array}$ & $\begin{array}{c}\text { Percentage } \\
\text { of Total }\end{array}$ & $\begin{array}{c}\text { Total } \\
\text { Responses }\end{array}$ & $\begin{array}{c}\text { Percentage } \\
\text { of Total }\end{array}$ \\
\hline Chosen by parents & 94 & 8.1 & 16 & 19.8 \\
\hline Chosen by selves & 940 & 81.1 & 56 & 69.1 \\
\hline Other methods & 99 & 8.6 & 8 & 9.9 \\
\hline No answer & 22 & 1.9 & 1 & 1.2 \\
\hline TOTAL & 1155 & 100.0 & 81 & 100.0 \\
\hline
\end{tabular}

Changes from the traditional methods of arranging marriages are clearly indicated in table 10. Among couples twenty-four years of age or under, 100 percent of the respondents reported that they chose their own marriage partner, but only 58.1 percent of those sixty and over reported self-chosen marriage partners. The degree of change is most notable among those fifty years of age or older, that is, those who had been married since the early $1950^{\prime} \mathrm{s}$.

A much larger percentage of the older couples, as compared to the younger ones, responded "other methods" when asked the method of choosing their marriage partner. This no doubt reflects the formerly common practice of resorting to a "go-between" to arrange a marriage. Those respondents who were sixty years of age or older said that 13.1 percent of their marriages were arranged by "other methods" and 25.1 percent of the marriage partners were "chosen by" parents. This indicates that in 38.2 percent of the pre-war marriages 
among Adventist families, the individual himself had little or nothing to say about the choice of his marriage partner. What effect, if any, this had on the happiness of the marriage will be indicated in table 72 .

TABLE 10

CORRELATION BETWEEN THE METHOD OF CHOOSING MARRIAGE PARTNERS AND THE AGE OF THE RESPONDENT

\begin{tabular}{|c|c|c|c|c|c|}
\hline \multirow{2}{*}{$\begin{array}{c}\text { Age Categories } \\
\text { of } \\
\text { Respondents }\end{array}$} & \multirow[b]{2}{*}{$\begin{array}{c}\text { Total } \\
\text { Responses }\end{array}$} & \multicolumn{4}{|c|}{ Percentage of Total } \\
\hline & & $\begin{array}{c}\text { Chosen by } \\
\text { Parents }\end{array}$ & $\begin{array}{c}\text { Chosen by } \\
\text { Selves }\end{array}$ & $\begin{array}{c}\text { Other } \\
\text { Methods }\end{array}$ & $\begin{array}{c}\text { No } \\
\text { Answer }\end{array}$ \\
\hline \multicolumn{6}{|l|}{24 years of age } \\
\hline or under & 18 & $-\infty$ & 100.0 & $-\infty$ & -- \\
\hline $25-29$ & 102 & 3.9 & 91.2 & 3.9 & 1.0 \\
\hline $30-34$ & 181 & 1.7 & 94.5 & 3.3 & .6 \\
\hline $35-39$ & 17.2 & .6 & .89 .5 & 9.3 & .6 \\
\hline $40-49$ & 305 & 3.6 & 84.9 & 9.5 & 2.0 \\
\hline $50-59$ & 186 & 14.5 & 72.0 & 10.2 & 3.2 \\
\hline \multicolumn{6}{|l|}{60 years of age } \\
\hline or more & 191 & 25.1 & 58.1 & 13.1 & 3.7 \\
\hline TOTAL & 1155 & & & & \\
\hline MEAN PERCENTAGE & & 8.1 & 81.4 & 8.6 & 1.9 \\
\hline
\end{tabular}

\section{Miai and Renai Form of Marriage Arrangement}

Miai and Renai describe two types of marriage arrangements. Miai refers to marriages in which the two parties to the marriage are brought together by a third party, the parents or a nakōo (marriage broker or "go-between"). This type of marriage arrangement 
may encompass those marriages in which the couple have little or no choice in the matter, perhaps meeting for the first time at the wedding, as well as those in which the couple themselves make the arrangements but invite a trusted, older friend of the family or their own to act as the nakodo. Renai arrangements are those in which the marriage partners themselves are drawn to each other on the basis of mutual love and make plans for getting married.

That there is a difference between the method of choosing a marriage partner and the form of the marriage arrangement can be seen by comparing table 11 with table 9 . Only 8.1 percent of the Adventist family respondents reported that their marriage partner was chosen by their parents (formerly understood to be included in the miai marriage). Another 8.6 percent reported that marriage partners were chosen by "other methods" (which includes the help of a nakōdo). Together these "arranged" marriages add up to 16.7 percent. However, 33.2 percent of the respondents, claimed that the form of their marriages was miai or "arranged."

TABLE 11

FORM OF MARRIAGE ARRANGEMENTS

\begin{tabular}{lcc}
\hline Forms of Arrangements & Number of Responses & Percentage of Total \\
\hline Miai form & 384 & 33.2 \\
Renai form & 472 & 40.9 \\
Other & 244 & 20.1 \\
No answer & 55 & 4.8 \\
\hline TOTAL & 1155 & 100.0 \\
\hline
\end{tabular}


Many respondents, 20.1 percent, reported some form other than the traditional miai or renai forms of marriage. Perhaps this together with the 4.8 percent who gave no answer to this question indicates the rapidly changing attitudes in marriage arrangements and the uncertainty of some as to just how their marriage arrangements fit into the traditional forms.

\section{Degree of Acquaintance Before Marriage}

When asked to respond to the question, "How well acquainted were you with your spouse before your marriage?" a surprisingly large percentage, 22.7 percent, responded that they were not acquainted at all or that they were only slightly acquainted, 36.0 percent (see t'able 12). This seems particularly noteworthy in the light of the fact that 81.1 percent said they had chosen their own marriage partner. The significance of these figures can be seen in table 73 which deals with the personal evaluation of the happiness in marriage.

In comparison to united families, divided families reported a much greater percentage, 32.1 percent, who had had no acquaintance at all before marriage. Also, the percentage of the divided families who were very well acquainted before marriage was somewhat less than that of united families.

\section{Education Level}

Table 13 gives the response of Adventist husbands and wives to the question concerning their level of education. Since the prewar education system of Japan was somewhat different from that of 
TABLE 12

DEGREE OF ACQUAINTANCE BEFORE MARRIAGE

\begin{tabular}{|c|c|c|c|c|}
\hline \multirow[b]{2}{*}{ Degree of Acquaintance } & \multicolumn{2}{|c|}{ United Families } & \multicolumn{2}{|c|}{ Divided Families } \\
\hline & $\begin{array}{c}\text { Total } \\
\text { Responses }\end{array}$ & $\begin{array}{c}\text { Percentage } \\
\text { of Total }\end{array}$ & $\begin{array}{c}\text { Total } \\
\text { Responses }\end{array}$ & $\begin{array}{l}\text { Percentage } \\
\text { of Total }\end{array}$ \\
\hline Not acquainted at all & 262 & 22.7 & 26 & 32.1 \\
\hline $\begin{array}{l}\text { Only slightly ac- } \\
\text { quainted }\end{array}$ & 416 & 36.0 & 25 & 30.9 \\
\hline $\begin{array}{l}\text { Rather well ac- } \\
\text { quainted }\end{array}$ & 239 & 20.7 & 17 & 21.0 \\
\hline Very well acquainted & 217 & 18.8 & 11 & 13.6 \\
\hline No answer & 21 & 1.8 & 2 & 2.5 \\
\hline TOTAL & 1155 & 100.0 & 81 & 100.1 \\
\hline
\end{tabular}

TABLE 13

LEVEL OF EDUCATION

\begin{tabular}{lccccc}
\hline Highest Level of & \multicolumn{2}{c}{ Husbands } & & \multicolumn{2}{c}{ Wives } \\
& $\begin{array}{c}\text { Total } \\
\text { Responses }\end{array}$ & $\begin{array}{c}\text { Percentage } \\
\text { of Total }\end{array}$ & $\begin{array}{c}\text { Total } \\
\text { Responses }\end{array}$ & $\begin{array}{c}\text { Percentage } \\
\text { of Total }\end{array}$ \\
\hline Junior high school & 164 & 28.4 & & 142 & 24.7 \\
Senior high school & 175 & 30.3 & & 229 & 39.9 \\
Junior college & 62 & 10.7 & & 162 & 28.2 \\
Senior college & 148 & 25.6 & & 35 & 6.1 \\
$\begin{array}{l}\text { Graduate level and } \\
\text { above }\end{array}$ & 26 & 4.5 & & 2 & .3 \\
No answer & 3 & .5 & & 4 & .7 \\
\hline TOTAL & 578 & 100.0 & 574 & 99.9 \\
\hline
\end{tabular}


today, it is difficult to classify with complete exactness education levels of individuals of all ages.

A noticeable difference can be seen in the levels of education of husbands and wives, for 30.1 percent of the men had an education level equivalent to senior college or above, while only 6.4 percent of the women had attained that level. However, there was a higher percentage of wives who had a junior college level of education.

Seventh-day Adventists are well known for their emphasis on education, a fact which is attested to by the large number of schools conducted by them in countries around the world. This emphasis seems to be reflected in the statistics in this table. More than one out of four of the husbands had received a degree from a four-year college and 4.5 percent had gone beyond that to receive some graduatelevel education. When comparing the Adventist education level with the education levels of the Japanese population as a whole (table 14) 1 it is apparent that Adventist husbands and wives are considerably more highly educated than the average citizen of Japan. Nearly seven times as many Adventist husbands have a senior college education or above as compared to the population as a whole. Statistics indicate that Adventist wives are also better educated, for 6.4 percent have a senior college education or above as compared to 4.7 percent of the total Japanese population.

One other statistic is worth noticing here; 49.3 percent of husbands of divided families has a senior college degree or above,

$$
{ }^{1} \text { Ibid., p. } 271 .
$$


a very high percentage. By far the great majority of these husbands are non-Adventists. Some of the Adventist wives, no doubt, married non-Adventist husbands, and some perhaps became Adventists after marriage. In any case, these well-educated non-Adventist spouses are a tremendous challenge to the church.

TABLE 14

EDUCATION LEVEL OF JAPANESE POPULATION OVER 15 YEARS OF AGE - 1970

\begin{tabular}{lcc}
\hline $\begin{array}{c}\text { Highest Level of } \\
\text { Education Attained }\end{array}$ & $\begin{array}{c}\text { Total } \\
\text { Number }\end{array}$ & $\begin{array}{c}\text { Percentage } \\
\text { of T.otal }\end{array}$ \\
\hline Equivalent of junior high school & $38,984,000$ & 49.4 \\
Equivalent of ten grades & $1,747,000$ & 2.2 \\
Equivalent of senior high school & $23,725,000$ & 30.1 \\
$\begin{array}{l}\text { Junior college or specialized } \\
\text { training }\end{array}$ & $2,938,000$ & 3.7 \\
$\begin{array}{l}\text { Senior college or above } \\
\text { Presently attending school }\end{array}$ & $3,720,000$ & 4.7 \\
No education and uneducable & $7,164,000$ & 9.1 \\
\hline Total & 573,000 & 99.9 \\
\hline
\end{tabular}

\section{Employment of Major Wage Earner}

Table 15 shows the employment statistics of the major wage earners of the united Adventist families and compares these figures to those of the divided families. It must be remembered that the responses given represent the respondents only, not the total number of families. Among the united families, 171, 29.6 percent, 1isted 
the major wage earner in the family as a Seventh-day Adventist church employee. In the divided families, only 2.5 percent were church employed.

TABLE 15

EMPLOYMENT OF MAJOR WAGE EARNER OF FAMILY

\begin{tabular}{|c|c|c|c|c|}
\hline \multirow[b]{2}{*}{ Employment Categories } & \multicolumn{2}{|c|}{ United Families } & \multicolumn{2}{|c|}{ Divided Families } \\
\hline & $\begin{array}{c}\text { Total } \\
\text { Responses }\end{array}$ & $\begin{array}{c}\text { Percentage } \\
\text { of Total }\end{array}$ & $\begin{array}{c}\text { Total } \\
\text { Responses }\end{array}$ & $\begin{array}{c}\text { Percentage } \\
\text { of Total }\end{array}$ \\
\hline $\begin{array}{l}\text { Seventh-day Adventist } \\
\text { church employee }\end{array}$ & 171 & 29.6 & 2 & 2.5 \\
\hline $\begin{array}{l}\text { Seventh-day Adventist } \\
\text { literature evangelists }\end{array}$ & 37 & 6.4 & -- & - \\
\hline $\begin{array}{l}\text { Self-employed (not in- } \\
\text { cluding literature } \\
\text { evangelists) }\end{array}$ & 136 & 23.5 & 14 & 17.3 \\
\hline Salaried--largely skilled & 83 & 14.4 & 23 & 28.4 \\
\hline Salaried--largely manual & 68 & 11.8 & 11 & 13.6 \\
\hline $\begin{array}{l}\text { Professional or } \\
\text { managerial }\end{array}$ & 72 & 12.5 & 30 & 37.0 \\
\hline Other & 5 & .9 & --- & --- \\
\hline No answer & 6 & 1.0 & 1 & 1.2 \\
\hline TOTAL & 578 & 100.1 & 81 & 100.0 \\
\hline
\end{tabular}

A word of caution is in order concerning these statistics. Assuming that a larger percentage of Adventist church employees returned the completed survey instrument than did the average united family spouse and that a greater percentage of those who did not complete them were backslidden and therefore not as likely to 
be church employees, it would seem that the 29.6 percent figure might be somewhat inflated. The same could also be said in regard to the 6.4 percent listed as Adventist colporteur evangelists.

Table 15 indicates that there was nearly two times the percentage of skilled salary workers and three times the percentage of professional and managerially employed individuals in the divided families as in united families. These major wage earners who in the large percentage of these divided families are non-members presents a challenge to the church to learn how to win to Christ these highly competent individuals.

Unfortunately the statistics do not reveal to which segmentis of the Japanese population the Adventist church is appealing and which it is failing to reach. Further study is needed to discover how many farmers, fishermen, miners, hard hats or government employees have responded to the gospel and which groups have been largely untouched.

\section{Income of the Adventist Family}

Tables 16 and 17 show the yearly family income of Seventh-day Adventist families. According to the Japan Times of May 24, 1976, the average Japanese workers' yearly income in 1972 was 1,800,000 and in 1974 it was 2,600,000. Although these figures may not be computed on the same basis as those in table 16 it does indicate that the income of the average Adventist family is not too far different from that of the average Japanese family. A considerably larger percentage of the divided families are in the higher income categories than are united families. This is in harmony with the 
figures in table 15 which show a greater percentage of the wage earners of divided families engaged in professional or managerial employment categories.

TABLE 16

YEARLY FAMILY INCOME

\begin{tabular}{|c|c|c|c|c|}
\hline \multirow{2}{*}{ Income categories } & \multicolumn{2}{|c|}{ United Families } & \multicolumn{2}{|c|}{ Divided Families } \\
\hline & $\begin{array}{c}\text { Total } \\
\text { Responses }\end{array}$ & $\begin{array}{c}\text { Percentage } \\
\text { of Total }\end{array}$ & $\begin{array}{c}\text { Total } \\
\text { Responses }\end{array}$ & $\begin{array}{c}\text { Percentage } \\
\text { of Total }\end{array}$ \\
\hline Less than one million yen & 85 & 14.7 & 5 & 6.2 \\
\hline One to three million yen & 384 & 66.4 & 35 & 43.2 \\
\hline Three to five million yen & 76 & 13.1 & 22 & 27.2 \\
\hline Over five million yen & 21 & 3.6 & 16 & 19.8 \\
\hline No answer & 12 & 2.1 & 3 & 3.7 \\
\hline TOTAL & 578 & 99.9 & 81 & 100.1 \\
\hline
\end{tabular}

The number of respondents who listed themselves in the selfsupporting category of employment is also rather high. The high percentage of those listed as the major wage earner who are Seventhday Adventist church employees, Seventh-day Adventist literature evangelists, or are self-employed reflects a problem facing many individuals who hold the beliefs and follow the teachings of the Adventist church. It is very difficult to find gainful employment that does not involve working on the seventh-day Sabbath. It can be conjectured that many of those members who are inactive in or unfaithful to the church are to some extent confronted by the problem. 
TABLE 17

CORRELATION BETWEEN THE YEARLY FAMILY INCOME AND THE EMPLOYMENT CATEGORY

\begin{tabular}{|c|c|c|c|c|c|c|}
\hline \multirow{2}{*}{$\begin{array}{l}\text { Employment } \\
\text { Categories }\end{array}$} & \multirow{2}{*}{$\begin{array}{c}\text { Total } \\
\text { Responses }\end{array}$} & \multicolumn{5}{|c|}{ Percentage of Total } \\
\hline & & $\begin{array}{l}\text { Less than One } \\
\text { Million Yen }\end{array}$ & $\begin{array}{l}\text { One to Three } \\
\text { Million Yen }\end{array}$ & $\begin{array}{l}\text { Three to Five } \\
\text { Million Yen }\end{array}$ & $\begin{array}{l}\text { Over Five } \\
\text { Million Yen }\end{array}$ & $\begin{array}{c}\text { No } \\
\text { Answer }\end{array}$ \\
\hline $\begin{array}{l}\text { Seventh-day Adventist } \\
\text { church employee }\end{array}$ & 171 & 7.6 & 86.5 & 5.3 & -- & .6 \\
\hline $\begin{array}{l}\text { Seventh-day Adventist } \\
\text { literature evangelists }\end{array}$ & 37 & 45.9 & 48.6 & 2.7 & --- & 2.7 \\
\hline $\begin{array}{l}\text { Self-employed (not in- } \\
\text { cluding literature } \\
\text { evangelists }\end{array}$ & 136 & 22.8 & 50.7 & 16.9 & 5.9 & 3.7 \\
\hline $\begin{array}{l}\text { Salaried--largely } \\
\quad \text { skilled }\end{array}$ & 83 & 9.6 & 72.3 & 14.5 & 2.4 & 1.2 \\
\hline Salaried--largely manual & 68 & 10.3 & 75.0 & 11.8 & --- & 2.9 \\
\hline $\begin{array}{l}\text { Professional or } \\
\text { managerial }\end{array}$ & 72 & 8.3 & 43.1 & 31.9 & 15.3 & 1.4 \\
\hline other & 5 & $-\cdots$ & 100.0 & $m-$ & --- & --- \\
\hline No answer & 6 & 50.0 & 33.3 & $-\cdots$ & $-\cdots$ & 16.7 \\
\hline TOTAL & 578 & & & & & \\
\hline MEAN PERCENTAGE & & 14.7 & 66.4 & 13.1 & 3.6 & 2.1 \\
\hline
\end{tabular}


A breakdown of yearly income by employment categories, as shown in table 17, shows that most Seventh-day Adventist church employees earned from one to three million yen a year. It also indicates that, with the exception of Adventist literature evangelists, a smaller percentage of Adventist church employees than any other category of employees had a yearly income of three million yen or more.

\section{Home Ownership and Housing Status}

Table 18 shows that 44.8 percent of the Adventist families owned their own homes. This compares to 59.2 percent of the population of Japan in general ${ }^{1}$ and 72.8 percent of the divided families who owned their own homes. Just a trifle more than half of the respondents reported living in employer-furnished housing.

A breakdown of housing status by employment is given in table 19. This indicates that of all categories listed, Seventhday Adventist employees show the lowest percentage of home ownership, the lowest percentage living with parents, and the highest percentage living in employer-furnished housing. Although the situation has changed in recent years, the Seventh-day Adventist church-employed families were still below average in home ownership. More than three times as high a percentage of literature evangelists owned their own homes as did other denominational employees.

${ }^{1}$ Ibid., p. 210 . 
Among those categories with the highest percentage of families owning their own homes, self-employed respondents, with 66.3 percent, and professional or managerial respondents, with 58.9 percent, stood highest. More than 4 percent of the total respondents reported that they were living with their parents. This no doubt included many who were the chonan, or eldest son, and who would inherit the family home when the parents passed away.

TABLE 18

HOUSING STATUS

\begin{tabular}{|c|c|c|c|c|}
\hline \multirow{2}{*}{$\begin{array}{l}\text { Housing Status } \\
\text { Categories }\end{array}$} & \multicolumn{2}{|c|}{ United Families } & \multicolumn{2}{|c|}{ Divided Families } \\
\hline & $\begin{array}{c}\text { Total } \\
\text { Responses }\end{array}$ & $\begin{array}{l}\text { Percentage } \\
\text { of Total }\end{array}$ & $\begin{array}{c}\text { Total } \\
\text { Responses }\end{array}$ & $\begin{array}{l}\text { Percentage } \\
\text { of Total }\end{array}$ \\
\hline Own home and living & & & & \\
\hline in it & 477 & 41.3 & 55 & 67.9 \\
\hline Own home but & & & & \\
\hline renting it out & 40 & 3.5 & 4 & 4.9 \\
\hline $\begin{array}{l}\text { Living in employer- } \\
\text { provided home }\end{array}$ & 580 & 50.2 & 17 & 21.0 \\
\hline Living with parents & 49 & 4.2 & 4 & 4.9 \\
\hline No answer & 9 & .8 & 1 & 1.2 \\
\hline TOTAL & 1155 & 100.0 & 81 & 99.9 \\
\hline
\end{tabular}


A CORRELATION BETWEEN THE HOUSING STATUS AND THE EMPLOYMENT CATEGORY

\begin{tabular}{|c|c|c|c|c|c|c|}
\hline \multirow[b]{2}{*}{ Employment Categories } & \multirow[b]{2}{*}{$\begin{array}{c}\text { Total } \\
\text { Respondents }\end{array}$} & \multicolumn{5}{|c|}{ Percentage of Total } \\
\hline & & $\begin{array}{l}\text { Own Home and } \\
\text { Living in It }\end{array}$ & $\begin{array}{l}\text { Own Home but } \\
\text { Renting It Out }\end{array}$ & $\begin{array}{l}\text { Living in Employer } \\
\text { Provided Home }\end{array}$ & $\begin{array}{l}\text { Living With } \\
\text { Parents }\end{array}$ & $\begin{array}{c}\text { No } \\
\text { Answer }\end{array}$ \\
\hline $\begin{array}{l}\text { Seventh-day Adventist } \\
\text { church employee }\end{array}$ & 346 & 11.3 & 5.8 & 80.1 & 1.4 & 1.4 \\
\hline $\begin{array}{l}\text { Seventh-day Adventist } \\
\text { 1iterature evangelists }\end{array}$ & 74 & 37.8 & 2.7 & 52.7 & 4.1 & 2.7 \\
\hline $\begin{array}{l}\text { Self-employed (not in- } \\
\text { cluding literature } \\
\text { evangelists. }\end{array}$ & 276 & 66.3 & 2.5 & 25.0 & 5.8 & .4 \\
\hline $\begin{array}{l}\text { Salaried--1argely } \\
\text { skilled }\end{array}$ & 164 & 42.7 & 3.7 & 43.3 & 10.4 & -- \\
\hline $\begin{array}{l}\text { Salaried--1argely } \\
\text { manual }\end{array}$ & 130 & 48.5 & 1.5 & 47.7 & 2.3 & --- \\
\hline $\begin{array}{l}\text { Professional or } \\
\text { managerial }\end{array}$ & 141 & 58.9 & 1.4 & 36.2 & 2.8 & .7 \\
\hline Other & 10 & 30.0 & -- & 70.0 & -- & -- \\
\hline No answer & 14 & 57.1 & 7.1 & 28.6 & 7.1 & -- \\
\hline TOTAL & 1155 & & & & & \\
\hline MEAN PERCENTAGE & & 41.3 & 3.5 & 50.2 & 4.2 & .8 \\
\hline
\end{tabular}


CHAPTER VI

\section{CHILDREN IN THE FAMILY}

\section{Number of Children in the Adventist Family}

According to the Japanese government census reports, the number of children in the average Japanese family has been decreasing in recent decades. In 1950 the average number of children in the Japanese family was 3.60 ; in 1960 , it was 3.20 ; and in $1970,2.71 .1$ By way of comparison, statistics derived from table 20 indicate that the average Adventist family in Japan in 1975 had 2.23 children. This was a slightly lower figure than those of Japan as a whole for 1970. However, when the national downward trend in family size over the past three decades is projected to 1975, the average Adventist family is only a few tenths of a percent smaller in size than the average Japanese family.

A study of tables 20 and 21 shows that more than half of all Adventist families, or 54.5 percent, had two or three children. By categories of employment, it can be seen that in larger sized families, that is families with four or more children, the major wage earner was either self-employed or employed in a professional or managerial capacity. This indicates that to a certain extent

$$
1_{\text {Ibid., p. } 18 .}
$$


the number of children in Adventist families may be related to both economic and mobility factors. For not only do the families classified as self-employed and professional or managerial have the largest families, but according to table 17 a'larger percentage of them have higher incomes, and table 19 shows that a higher percentage own their own homes.

TABLE 20

NUMBER OF CHILDREN IN THE FAMILY

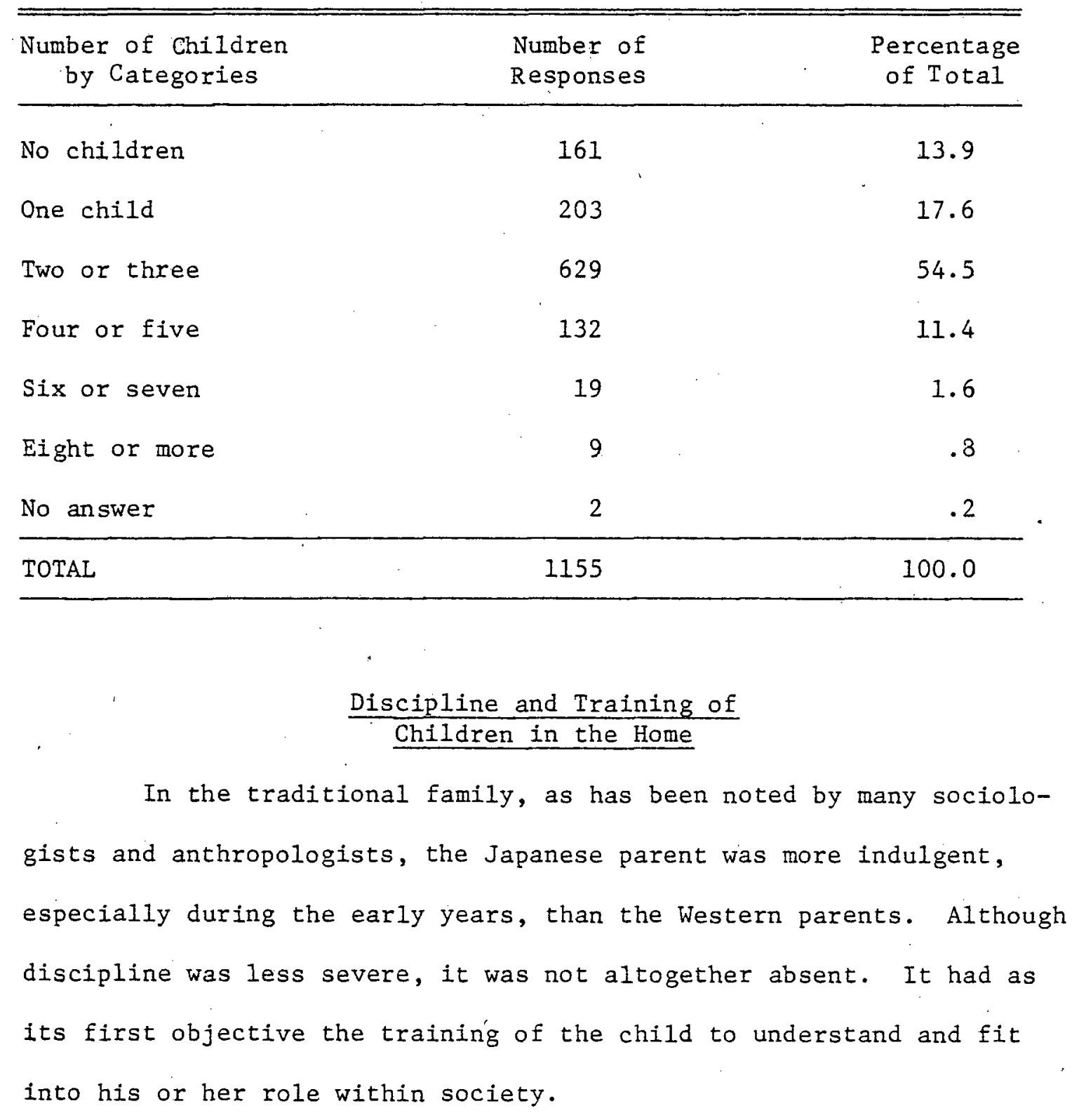


TABLE 21

CORRELATION BETWEEN THE NUMBER OF CHILDREN AND THE EMPLOYMENT CATEGORY

\begin{tabular}{|c|c|c|c|c|c|c|c|}
\hline \multirow{2}{*}{$\begin{array}{c}\text { Employment Categories } \\
\text { of Parents }\end{array}$} & \multirow{2}{*}{$\begin{array}{l}\text { Number of } \\
\text { Responses }\end{array}$} & \multicolumn{6}{|c|}{ Percentage of Total } \\
\hline & & $\begin{array}{c}\text { No } \\
\text { Children }\end{array}$ & $\begin{array}{c}1 \\
\text { Child }\end{array}$ & $\begin{array}{c}2-3 \\
\text { Children }\end{array}$ & $\begin{array}{c}4-5 \\
\text { Children }\end{array}$ & $\begin{array}{c}6-7 \\
\text { Children }\end{array}$ & $\begin{array}{l}8 \text { or more } \\
\text { Children }\end{array}$ \\
\hline Adventist church employee & 346 & 10.8 & 14.5 & 67.9 & 5.5 & .9 & .3 \\
\hline Adventist literature evangelist & 74 & 20.3 & 20.3 & 41.9 & 14.9 & --- & 2.7 \\
\hline $\begin{array}{l}\text { Self-employed (not including } \\
\text { literature evangelist) }\end{array}$ & 276 & 9.8 & 13.4 & 52.5 & 19.9 & 2.5 & 1.8 \\
\hline Salaried--largely skilled & 164 & 23.8 & 17.7 & 47.6 & 7.9 & 1.8 & .6 \\
\hline Salaried--1argely manual & 130 & 15.4 & 32.3 & 50.8 & 1.5 & --- & --- \\
\hline Professional or managerial & 141 & 11.3 & 19.1 & 47.5 & 18.4 & 3.5 & --- \\
\hline Other & 10 & 30.0 & 20.0 & 20.0 & 30.0 & --- & -- \\
\hline No answer & 14 & 28.6 & 7.1 & 45.7 & 21.4 & 7.1 & --- \\
\hline TOTAL & 1155 & & & & & & \\
\hline MEAN PERCENTAGE & & 13.9 & 17.6 & 54.5 & 11.4 & 1.6 & .8 \\
\hline
\end{tabular}


What of the Adventist family? To what extent were these traditional traits regarding discipline and training seen? Table 22 tabulates the responses to the question concerning this aspect of family life. Of those who answered, 19.5 percent reported that they used an authoritarian type of discipline with their children, 3.4 percent considered their methods to be permissive, and 68.8 percent, the largest percentage, reported democratic discipline. A weakness of this particular question was that the terms "Authoritarian," "Permissive," and "Democratic," as they apply to child training and discipline, were not explained. It was thus not really possible for the respondent to evaluate himself fairly.

TABLE 22

TYPES OF DISCIPLINE AIND TRAINING OF CHILDREN

\begin{tabular}{lcccr}
\hline \hline $\begin{array}{l}\text { Categories of } \\
\text { Discipline and } \\
\text { Training }\end{array}$ & $\begin{array}{c}\text { Number of } \\
\text { Responses }\end{array}$ & Total & Husband & Wife \\
\cline { 5 - 6 } Authoritarian & 179 & 19.5 & 20.2 & 18.8 \\
$\begin{array}{l}\text { Permissive } \\
\text { Democratic }\end{array}$ & 31 & 3.4 & 4.7 & 2.0 \\
$\begin{array}{l}\text { Combination of the } \\
\text { above, or other }\end{array}$ & 632 & 68.8 & 67.3 & 70.3 \\
\hline TOTAL & 77 & 8.4 & 7.7 & 8.9 \\
\hline
\end{tabular}

Both fathers and mothers by a wide margin over other types, listed their type of discipline and training used in their homes as democratic. Fathers described themselves as slightly more authoritarian in their training than mothers. They also described themselves as more permissive. 
Christian Education and the

Adventist Family

Historically, Seventh-day Adventists have placed strong emphasis on Christian education. In countries all around the world, they have placed a very high priority on establishing churchoriented schools wherever there were Adventist church members. They have felt that these Christian schools were one of the best investments in programs designed to establish and strengthen the faith of the children and youth of the church.

These schools have often been established at great sacrifice. And with equally great sacrifice and in spite of opposition Adventist parents have sent their children to attend them. To what extent have Adventist parents in Japan supported the educational program of the church by sending their children to the primary schools, junior and senior high schools, and the college operated by the church in Japan?

Table 23 shows that nearly three-fourths of the united families and one-half of the divided families sent some or all of their children to these church-operated schools. And table 24 indicates that Adventists in all employment categories strongly supported Christian education. Of Adventist church employees, 80.8 percent sent all their children to church operated schools.' Adventists in the professional or managerial category sent 38.1 percent of their children to Seventh-day Adventist schools. According to table 25 all income groups supported the educational program of the church by sending all or some of their children to Seventh-day Adventist schools. The highest support came from those in the $¥ 1-3,000,000$ yearly income category. The 
TABLE 23

CHILDREN SENT TO ADVENTIST SCHOOLS

\begin{tabular}{lccccc}
\hline \hline $\begin{array}{c}\text { Extent to which } \\
\text { Children were } \\
\begin{array}{c}\text { Sent to Adventist } \\
\text { Schools }\end{array}\end{array}$ & $\begin{array}{c}\text { United Families } \\
\text { Responses }\end{array}$ & $\begin{array}{c}\text { Percentage } \\
\text { of Total }\end{array}$ & $\begin{array}{c}\text { Dotal } \\
\text { Responses }\end{array}$ & $\begin{array}{c}\text { Percentage } \\
\text { of Total }\end{array}$ \\
\hline All children sent & 421 & 57.7 & & 14 & 24.1 \\
Some children sent & 113 & 15.5 & & 13 & 22.4 \\
No children sent & 196 & 26.8 & 31 & 53.5 \\
\hline TOTAL & 730 & 100.0 & 58 & 100.0 \\
\hline
\end{tabular}

TABLE 24

CORRELATION BETWEEN CHILDREN SENT TO ADVENTIST SCHOOLS AND THE EMPLOYMENT CATEGORIES OF PARENTS

\begin{tabular}{|c|c|c|c|c|}
\hline \multirow[b]{2}{*}{$\begin{array}{c}\text { Employment Categories } \\
\text { of Parents }\end{array}$} & \multirow{2}{*}{$\begin{array}{l}\text { Number of } \\
\text { Responses }\end{array}$} & \multicolumn{3}{|c|}{ Percentages of Total } \\
\hline & & $\begin{array}{l}\text { Al1 } \\
\text { Children } \\
\text { Sent }\end{array}$ & $\begin{array}{l}\text { Some } \\
\text { Children } \\
\text { Sent }\end{array}$ & $\begin{array}{l}\text { No } \\
\text { Children } \\
\text { Sent }\end{array}$ \\
\hline Adventist church employee & 224 & 80.8 & 5.8 & 13.4 \\
\hline $\begin{array}{l}\text { Adventist literature } \\
\text { evangelist }\end{array}$ & 51 & 54.9 & 23.5 & 21.6 \\
\hline $\begin{array}{l}\text { Self-employed (not in- } \\
\text { cluding literature } \\
\text { evangelist }\end{array}$ & 195 & 45.1 & 20.0 & 34.9 \\
\hline Salaried--largely skilled & 78 & 50.0 & 10.3 & 39.7 \\
\hline Salaried--largely manual & 72 & 59.7 & 9.7 & 30.6 \\
\hline Professional or managerial & 97 & 38.1 & 38.1 & 28.9 \\
\hline Other & 5 & 40.0 & --- & 60.0 \\
\hline No answer & 8 . & 37.5 & 25.0 & 37.5 \\
\hline TOTAL & 730 & & & \\
\hline MEAN PERCENTAGE & & 57.7 & 15.5 & 24.1 \\
\hline
\end{tabular}


TABLE 25

CORRELATION BETWEEN CHILDREN SENT TO ADVENTIST SCHOOLS AND THE YEARLY FAMILY INCOME

\begin{tabular}{|c|c|c|c|c|}
\hline \multirow[b]{2}{*}{$\begin{array}{c}\text { Yearly Family Income } \\
\text { by Categories }\end{array}$} & \multirow[b]{2}{*}{$\begin{array}{l}\text { Number of } \\
\text { Responses }\end{array}$} & \multicolumn{3}{|c|}{ Percentages of Total } \\
\hline & & $\begin{array}{c}\text { All } \\
\text { Children } \\
\text { Sent }\end{array}$ & $\begin{array}{c}\text { Some } \\
\text { Children } \\
\text { Sent }\end{array}$ & $\begin{array}{l}\text { No } \\
\text { Children } \\
\text { Sent }\end{array}$ \\
\hline Less than $¥ 1,000,000$ & 104 & 40.4 & 26.0 & 33.7 \\
\hline$¥ 1-3,000,000$ & 467 & 63.6 & 11.8 & 24.6 \\
\hline$¥ 3-5,000,000$ & 115 & 49.6 & 19.1 & 31.3 \\
\hline More than $¥ 5,000,000$ & 31 & 61.3 & 16.1 & 22.6 \\
\hline No answer & 13 & 46.2 & 30.8 & 23.0 \\
\hline TOTAL & 730 & & & \\
\hline MEAN PERCENTAGE & & 57.7 & 15.5 & 26.9 \\
\hline
\end{tabular}

lowest support came from those whose yearly income was less than $¥ 1,000,000$. Table 26 indicates that there was very little difference in the amount of support given Adventist schools by first, second, or third generation Seventh-day Adventist church members. The percentage of each category that sent no children to these schools was very similar.

Table 27 breaks down the support of Adventist parents according to their educational level. In general, the higher the level of education, the greater is the percentage of those sending their children to Adventist schools.

The writings of Ellen G. White, known as the Spirit of Prophecy and believed by Seventh-day Adventists to be especially 
TABLE 26

CORRELATION BETWEEN CHILDREN SENT TO ADVENTIST SCHOOLS AND THE ADVENTIST BACKGROUND OF PARENTS

\begin{tabular}{lcccc}
\hline & & \multicolumn{3}{c}{ Percentage of Total } \\
\cline { 3 - 5 } $\begin{array}{c}\text { Adventist Background } \\
\text { of Parents }\end{array}$ & $\begin{array}{c}\text { Number of } \\
\text { Responses }\end{array}$ & $\begin{array}{c}\text { All } \\
\text { Children } \\
\text { Sent }\end{array}$ & $\begin{array}{c}\text { Some } \\
\text { Children } \\
\text { Sent }\end{array}$ & $\begin{array}{c}\text { Children } \\
\text { Sent }\end{array}$ \\
\hline $\begin{array}{l}\text { No background, first- } \\
\text { generation Adventist }\end{array}$ & 587 & 58.1 & 15.8 & 26.1 \\
$\begin{array}{l}\text { Second-generation Adventist } \\
\begin{array}{l}\text { Third- or fourth-generation } \\
\text { Adventist }\end{array}\end{array}$ & 108 & 56.5 & 15.7 & 27.8 \\
$\begin{array}{l}\text { No answer } \\
\text { TOTAL }\end{array}$ & 26 & 61.5 & 11.5 & 26.9 \\
\begin{tabular}{l} 
MEAN PERCENTAGE \\
\hline
\end{tabular} & 730 & 33.3 & -15.5 & 66.7 \\
\hline
\end{tabular}

TABLE 27

CORRELATION BETWEEN CHILDREN SENT TO ADVENTIST SCHOOLS AND THE EDUCATION LEVEL OF PARENTS

\begin{tabular}{|c|c|c|c|c|}
\hline \multirow[b]{2}{*}{$\begin{array}{c}\text { Education Level } \\
\text { of Parents }\end{array}$} & \multirow[b]{2}{*}{$\begin{array}{l}\text { Number of } \\
\text { Responses }\end{array}$} & \multicolumn{3}{|c|}{ Percentage of Total } \\
\hline & & $\begin{array}{c}\text { All } \\
\text { Children } \\
\text { Sent }\end{array}$ & $\begin{array}{c}\text { Some } \\
\text { Children } \\
\text { Sent }\end{array}$ & $\begin{array}{c}\text { No } \\
\text { Children } \\
\text { sent }\end{array}$ \\
\hline Junior high school & 219 & 49.8 & 18.7 & 31.5 \\
\hline Senior high school & 261 & 59.8 & 14.2 & 26.1 \\
\hline Junior college & 129 & 62.8 & 11.6 & 25.6 \\
\hline Senior college & 99 & 57.8 & 17.2 & 25.3 \\
\hline Graduate school & 19 & 79.0 & 15.8 & 5.3 \\
\hline No answer & 3 & --- & --- & --- \\
\hline TOTAL & 730 & & & \\
\hline MEAN PERCENTAGE & & 57.7 & 15.5 & 26.9 \\
\hline
\end{tabular}


inspired of God, often advocate the importance of Christian education. Questions were designed to discover to what extent an Adventist member's ownership of, and presumably his belief in, these writings effected his support of the Adventist educational system. The responses are tabulated in table 28 . In general, the more Spirit of Prophecy books found in their homes, the greater was the degree of support for the school system.

There was a rather small number of parents reporting that they had no Spirit of Prophecy books in their homes, and yet a rather high percentage of these reported that they had sent or were sending their children to Adventist schools. Just why this was so is not entirely evident. It could be that the small population in this category was not sufficient to give a true picture. It could also be that these respondents represented newly converted members who had not yet secured Ellen White's books.

Table 29 shows how the attitude of the non-Adventist spouse affected the percentage of children from divided families who were sent to Adventist schools. The population involved was not large, only fifty-eight respondents in all, but the figures indicated that there may be a decided relationship. Where the non-Adventist spouse was strongly opposed to the church, none of the children from these divided families was sent to Adventist schools. On the other hand, when there was a strong interest on the part of the non-Adventist spouse in the church, 50 percent sent all or some of their children to Adventist schools. It is perhaps not surprising that the percentage of divided families who sent al1 
TABLE 28

CORRELATION BETWEEN CHILDREN SENT TO ADVENTIST SCHOOLS AND THE NUMBER OF SPIRIT OF PROPHECY BOOKS IN HOME

\begin{tabular}{lcccc}
\hline & & \multicolumn{2}{c}{ Percentage of Total } \\
\cline { 4 - 5 } $\begin{array}{c}\text { Number of Spirit of } \\
\text { Prophecy Books in } \\
\text { the Home }\end{array}$ & $\begin{array}{c}\text { Number of } \\
\text { Responses }\end{array}$ & $\begin{array}{c}\text { All } \\
\text { Children } \\
\text { Sent }\end{array}$ & $\begin{array}{c}\text { Some } \\
\text { Children } \\
\text { Sent }\end{array}$ & $\begin{array}{c}\text { Children } \\
\text { Sent }\end{array}$ \\
\hline None & 13 & 53.9 & 7.7 & 38.5 \\
$1-3$ volumes & 33 & 33.3 & 9.1 & 57.6 \\
$4-10$ volumes & 163 & 42.9 & 21.5 & 35.6 \\
More than 10 volumes & 513 & 64.3 & 13.8 & 21.8 \\
No answer & 8 & 37.5 & 37.5 & 25.0 \\
\hline TOTAL & 730 & & & 26.9 \\
MEAN PERCENTAGE & & 57.7 & 15.5 & \\
\hline
\end{tabular}

TABLE 29

CORRELATION BETWEEN CHILDREN SENT TO ADVENTIST SCHOOLS AND THE NON-ADVENTIST SPOUSE'S ATTITUDES TOWARD CHURCH

\begin{tabular}{|c|c|c|c|c|}
\hline \multirow{2}{*}{$\begin{array}{c}\text { Non-Adventist Spouse's } \\
\text { Attitudes Toward } \\
\text { the Church }\end{array}$} & \multirow[b]{2}{*}{$\begin{array}{l}\text { Number of } \\
\text { Responses }\end{array}$} & \multicolumn{3}{|c|}{ Percentage of Total } \\
\hline & & $\begin{array}{l}\text { All } \\
\text { Children } \\
\text { Sent }\end{array}$ & $\begin{array}{l}\text { Some } \\
\text { Children } \\
\text { Sent }\end{array}$ & $\begin{array}{l}\text { No } \\
\text { Children } \\
\text { Sent }\end{array}$ \\
\hline Strongly opposed & 7 & --- & $-\infty$ & 100.0 \\
\hline Somewhat opposed & 5 & 20.0 & .20 .0 & 60.0 \\
\hline No interest but not opposed & 9 & --- & 22.2 & 77.8 \\
\hline Somewhat interested & 30 & 40.0 & 26.7 & 33.3 \\
\hline Strongly interested & 6 & 16.7 & 33.3 & 50.0 \\
\hline No answer & 1 & --- & --- & 100.0 \\
\hline TOTAL & 58 & & & \\
\hline MEAN PERCENTAGE & & 24.1 & 22.4 & 53.5 \\
\hline
\end{tabular}


their children to Adventist schools was less than half that of united families, 24.1 percent as compared to 57.7 percent.

The large percentage of children from Adventist families who were sent to Adventist schools has already been noted. However, table 23 also shows that 26.8 percent of the children from these united families and 53.5 percent from the divided homes were not sent to Adventist schools. Table 30 tells why they were not sent. In the case of the united families, 59.2 percent of the parents reported that they did not send their children to Adventist schools because there was no school nearby. Nearly 14 percent gave financial reasons for not sending their children, and a small 2.3 percent felt that Adventist schools were inferior. The greatest reason for the divided families was personal or family preferences.

TABLE 30

REASONS FOR NOT SENDING CHILDREN

TO ADVENTIST SCHOOLS

\begin{tabular}{lccccc}
\hline & \multicolumn{2}{c}{ United Families } & & Divided Families \\
\cline { 5 - 6 } \cline { 5 - 6 } Categories of Reasons & $\begin{array}{c}\text { Total } \\
\text { Responses }\end{array}$ & $\begin{array}{c}\text { Percentage } \\
\text { of Total }\end{array}$ & $\begin{array}{c}\text { Total } \\
\text { Responses }\end{array}$ & $\begin{array}{c}\text { Percentage } \\
\text { of Total }\end{array}$ \\
\hline $\begin{array}{l}\text { No nearby Adventist } \\
\text { school }\end{array}$ & 116 & 59.2 & 12 & 38.7 \\
$\begin{array}{l}\text { Financial reasons } \\
\begin{array}{l}\text { Adventist schools con- } \\
\text { sidered inferior }\end{array}\end{array}$ & 27 & 13.8 & 1 & 3.2 \\
$\begin{array}{l}\text { Personal or family } \\
\text { preference }\end{array}$ & 58 & 2.3 & 2 & 6.5 \\
\hline \begin{tabular}{l} 
Total \\
\hline
\end{tabular} & 196 & 100.0 & 31 & 100.0 \\
\hline
\end{tabular}




\section{Parental Ambitions for Eldest Son}

Traditionally, Japanese parents greatly favored the firstborn son of the family. As bearer of the family name, upholder of the family traditions and honor, and inheritor of the family fortunes, he was held in a position of special favor and treated accordingly.

Table 31 records the responses to the question as to what profession Adventist parents would desire their eldest son to follow, if they could influence him to do so. The 4.5 percent who desired that their son should carry on the family business certainly was a drastic decline from the desires of the traditional family of one hundred years ago.

The parents' preferences for their eldest son's future life work is arranged by percentage according to their greatest preferences. One point of interest is the strong desire expressed by Adventist parents that their eldest son enter some aspect of the medical profession. Nearly one of every four indicated that this was their preference, which would seem to be higher than that of the population at large. Some indication of this difference can be seen, perhaps, by comparing the 24.5 percent of parents of united families who chose the medical profession for their sons with the 19.6 percent of the parents in divided homes who chose that profession. Although there is a difference, there is still a rather high percentage who chose the medical profession in both categories. Adventists who were professionally or managerially employed opted highest for the medical profession (see table 32). Those who 
were self-employed ranked lowest in their desire for such a career for their sons. Adventist church employees also stood high in this respect.

TABLE 31

PARENTS' PREFERENCE FOR ELDEST SON'S FUTURE LIFE WORK

\begin{tabular}{|c|c|c|c|c|}
\hline \multirow{2}{*}{$\begin{array}{l}\text { Categories of } \\
\text { Future Work }\end{array}$} & \multicolumn{2}{|c|}{ United Families } & \multicolumn{2}{|c|}{ Divided Families } \\
\hline & $\begin{array}{c}\text { Total } \\
\text { Responses }\end{array}$ & $\begin{array}{c}\text { Percentage } \\
\text { of Total }\end{array}$ & $\begin{array}{c}\text { Total } \\
\text { Responses }\end{array}$ & $\begin{array}{c}\text { Percentage } \\
\text { of Total }\end{array}$ \\
\hline $\begin{array}{l}\text { Medically related } \\
\text { employment }\end{array}$ & 167 & 24.5 & 9 & 19.6 \\
\hline Technician & 113 & 16.5 & 10 & 21.7 \\
\hline Teaching & 96 & 14.1 & 4 & 8.7 \\
\hline Self-supporting business & 81 & 11.9 & 5 & 10.9 \\
\hline Gospel ministry & 76 & 11.1 & 5 & 10.9 \\
\hline Other & 49 & 7.2 & 1 & 2.2 \\
\hline Carry on family business & 31 & 4.5 & - & $---\infty$ \\
\hline $\begin{array}{l}\text { Salaried man in de- } \\
\text { pendable firm }\end{array}$ & 29 & 4.3 & 8 & 17.4 \\
\hline Farming & 16 & 2.3 & -- & --- \\
\hline Colporteuring & 10 & 1.5 & 2 & 4.3 \\
\hline Skilled labor & 9 & 1.3 & -- & --- \\
\hline Clerk or office worker & 5 & .7 & 2 & 4.3 \\
\hline Politician & 1 & .2 & - & --- \\
\hline Salesman & -- & $-\cdots-$ & $-\infty$ & ---- \\
\hline TOTAL & 683 & 100.1 & 46 & 100.0 \\
\hline
\end{tabular}


TABLE 32

CORRELATION BETWEEN PARENTS' PREFERENCE FOR ELDEST SON'S FUTURE LIFE WORK AND THE EMPLOYMENT CATEGORIES OF PARENTS

\begin{tabular}{|c|c|c|c|c|c|c|c|c|c|c|c|c|}
\hline $\begin{array}{c}\text { Employment Categories } \\
\text { of Parents }\end{array}$ & 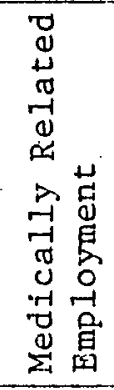 & 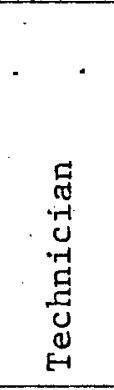 & 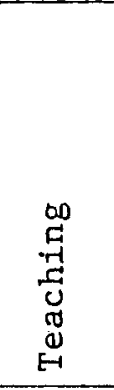 & 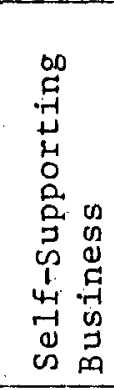 & 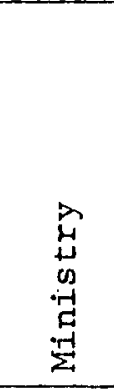 & 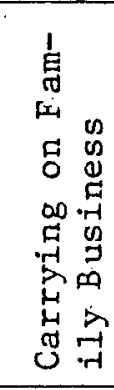 & 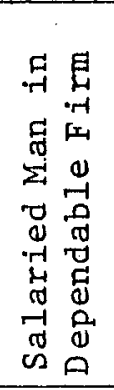 & 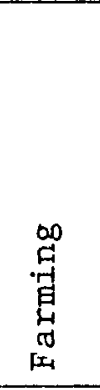 & 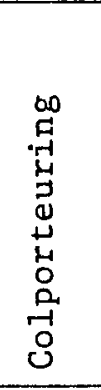 & 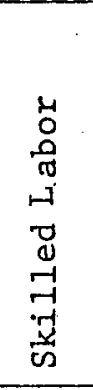 & 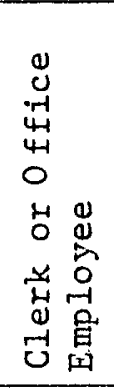 & 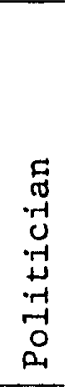 \\
\hline Adventist church employee & 29.2 & 20.8 & 13.0 & 2.8 & 20.4 & .9 & 1.4 & .9 & 1.9 & .9 & .9 & .5 \\
\hline Adventist literature evangelist & 25.0 & 11.1 & 13.9 & 11.1 & 11.1 & -- & 2.8 & -- & 8.3 & -- & 5.6 & - \\
\hline $\begin{array}{l}\text { Self-employed (not including } \\
\text { literature evangelist) }\end{array}$ & 12.1 & 11.6 & 12.1 & 29.5 & 6.9 & 10.4 & 4.1 & 6.4 & 1.2 & --- & .6 & -- \\
\hline Salaried--largely skilled & 29.7 & 12.1 & 19.8 & 12.1 & 7.7 & 2.2 & 6.6 & 1.1 & 1.1 & 1.1 & --- & -- \\
\hline Salaried--largely manual & 24.6 & 23.2 & 10.1 & 5.8 & 8.7 & 5.8 & 8.7 & 2.9 & -- & 5.8 & --- & -- \\
\hline Professional or managerial & 32.6 & 14.6 & 19.1 & 5.6 & 3.4 & 4.5 & 5.6 & -- & --- & 2.3 & -- & -- \\
\hline MEAN PERCENTAGE & 24.5 & 16.5 & 14.1 & 11.9 & 11.1 & 4.5 & 4.3 & 2.3 & 1.5 & 1.3 & .7 & .2 \\
\hline
\end{tabular}


A study of the statistics in table 32 also seems to indicate that the problem of Sabbath-keeping affected Adventist parents' preferences. For instance, very few parents from united homes chose office work or salaried employment in a firm as a life work for their sons. Sabbath-keeping would be a problem in these occupations. Parents of divided homes, however, were much more apt to choose these occupations, and a fairly large percentage of all parents of divided homes chose employment by a reputable firm as desirable for their first-born son. Sabbath-keeping was evidently not as much a factor in the thinking of these parents.

More than 10 percent of all Adventist families wished that their eldest son would become a gospel minister. This was true not only of parents of united families but also of divided homes. This certainly says something about the commitment of these parents to Christianity and the Adventist church. When studied from the point of view of parents' employment categories, it can be seen that Adventist church employees were highest in choosing the ministry for their sons, 20.4 percent; Adventist literature evangelists came next, 11.1 percent; and professional or managerial parents ranked 1ast, 3.4 percent.

It is also interesting, though perhaps not unsuspected, that the highest percentage of parents who chose a self-supporting business for their eldest son were themselves engaged in a selfsupporting occupation. The same was also true of colporteurs, salaried workers, and church employees. 
Adventist Parents' 'Influence on

Their Children's Conversion

Among the greatest longings of genuine Christians is that

the experience that has warmed and changed their own lives will

also be experienced by their children. This is not always the

case, however. Table 33 records the opinions of Adventist parents

as to how they felt they could best influence their children to accept Christ as their Savior. Each parent was asked to choose the two influences he thought most effective.

TABLE 33

PARENTAL OPINION AS TO THEIR OWN GREATEST

INFLUENCE ON THEIR CHILDRENS' CONVERSION

\begin{tabular}{lcc}
\hline Categories of Greatest Influence & $\begin{array}{c}\text { Total } \\
\text { Responses }\end{array}$ & $\begin{array}{c}\text { Percentage } \\
\text { of Total }\end{array}$ \\
\hline $\begin{array}{l}\text { Provide a Christian education } \\
\text { Pray for them }\end{array}$ & 1224 & 28.2 \\
$\begin{array}{l}\text { Love and encourage them } \\
\begin{array}{l}\text { Give them proper training and } \\
\text { home discipline }\end{array}\end{array}$ & 1279 & 29.4 \\
$\begin{array}{l}\text { Provide them a consistent example } \\
\text { of Christian living }\end{array}$ & 276 & 10.8 \\
$\begin{array}{l}\text { Other } \\
\text { ToTAL }\end{array}$ & 1081 & 24.9 \\
\hline
\end{tabular}

The largest number of parents, 29.4 percent, thought the most effective influence was to pray for their children. This was followed closely by 28.2 percent of the parents who felt that providing their children with a Christian education in Adventist schools was the most 
effective, and 24.9 percent who listed demonstrating in their own lives an example of Christian living to be the most effective influence. It seems a bit surprising that proper training and discipline in the home ranked so low on the list of effective influences, only 6.4 percent.

\section{Importance of Marriage of Children to Church Members}

Seventh-day Adventist church members have often been taught from the pulpit, in church publications, and especially in the writings of the Spirit of Prophecy of the importance of marrying within the church and of the dangers of marriage to a non-member. Just how strongly do parents of Adventist families in Japan feel about these teachings?

Table 34 indicates that the parents of both united and divided families were in strong accord with such counsel, with 59.9 percent of the former and 37.3 percent of the latter expressing strong opposition to their children marrying a non-member. The Adventist parent of the divided family, although agreeing with the importance of their children marrying a church member, felt, to a greater extent than the parents of united families, that the final decision must be left to the children themselves. Tables 35-39 reveal which groups in the church felt the strongest in regard to the marriage of their children to church members. Table 35 shows that 78.0 percent of the Adventist colporteurs and 74.9 percent of the church employees felt the strongest on the subject of children marrying non-church members. 
TABLE 34

PARENTAL OPINION AS TO THE IMPORTANCE OF THEIR CHILDREN MARRYING AN ADVENTIST CHURCH MEMBER

\begin{tabular}{|c|c|c|c|c|}
\hline \multirow[b]{2}{*}{ Parental Opinion } & \multicolumn{2}{|c|}{ United Families } & \multicolumn{2}{|c|}{ Divided Families } \\
\hline & $\begin{array}{c}\text { Total } \\
\text { Responses }\end{array}$ & $\begin{array}{l}\text { Percentage } \\
\text { of Total }\end{array}$ & $\begin{array}{c}\text { Total } \\
\text { Responses }\end{array}$ & $\begin{array}{l}\text { Percentage } \\
\text { of Total }\end{array}$ \\
\hline $\begin{array}{l}\text { Very important, } \\
\text { strongly oppose } \\
\text { marriage to a non- } \\
\text { member. }\end{array}$ & 591 & 59.9 & 25 & 37.3 \\
\hline $\begin{array}{l}\text { Very important, but } \\
\text { would leave the } \\
\text { decision to the } \\
\text { children. }\end{array}$ & 368 & 37.3 & 42 & 62.7 \\
\hline $\begin{array}{l}\text { Not too important, } \\
\text { their happiness is } \\
\text { most important. }\end{array}$ & 27 & 2.7 & -- & --- \\
\hline TOTAL & 986 & 99.9 & 67 & 100.0 \\
\hline
\end{tabular}

According to table 36 , both husbands and wives strongly opposed their children marrying a non-member; although husbands were slightly more inclined to leave the final decision to the children. Secondgeneration Adventists more than first and third-generation Adventists felt the importance of marrying within the church (see table 37).

A decided relationship between regularity in conducting family worship and attitudes toward marriage can be seen in table 38 . of those who held regular morning and evening worship in the home, 72.3 percent strongly opposed their children's marriage to a nonmember. This was twice the percentage of those who never conducted family worship and who opposed marriage to non-members (35.5). 
TABLE 35

CORRELATION BETWEEN PARENTAL OPINION AS TO THE IMPORTANCE OF

THEIR CHILDREN MARRYING AN ADVENTIST AND THE

EMPLOYMENT CATEGORIES OF PARENTS

\begin{tabular}{|c|c|c|c|c|}
\hline \multirow[b]{2}{*}{$\begin{array}{c}\text { Employment Categories } \\
\text { of Parents }\end{array}$} & \multirow[b]{2}{*}{$\begin{array}{l}\text { Number of } \\
\text { Responses }\end{array}$} & \multicolumn{3}{|c|}{ Percentage of Total } \\
\hline & & $\begin{array}{c}\text { Very Important-- } \\
\text { Strongly Oppose } \\
\text { Marriage to a Non- } \\
\text { Member. }\end{array}$ & $\begin{array}{l}\text { Very Important-- } \\
\text { but Would Leave } \\
\text { the Decision to } \\
\text { the Children. }\end{array}$ & $\begin{array}{c}\text { Not too Important-- } \\
\text { Their Happiness } \\
\text { is the Most Im- } \\
\text { portant. }\end{array}$ \\
\hline Adventist church employee & 311 & 74.9 & 24.8 & .3 \\
\hline $\begin{array}{l}\text { Adventist 1iterature } \\
\text { evangelist }\end{array}$ & 59 & 78.0 & 22.0 & -- \\
\hline $\begin{array}{l}\text { Self-employed (not in- } \\
\text { cluding literature } \\
\text { evangelist) }\end{array}$ & 237 & 51.9 & 44.7 & 3.8 \\
\hline $\begin{array}{l}\text { Salaried--1argely } \\
\text { skilled labor }\end{array}$ & 130 & 50.0 & 44.6 & 5.4 \\
\hline $\begin{array}{l}\text { Salaried--largely } \\
\text { manual labor }\end{array}$ & 110 & 51.8 & 44.6 & 3.6 \\
\hline Professional or managerial & 123 & 48.8 & 47.2 & 4.1 \\
\hline other & 8 & 50.0 & 50.0 & -- \\
\hline No answer & 8 & 50.0 & 37.5 & 12.5 \\
\hline TOTAL & 986 & & & \\
\hline MEAN PERCENTAGE & & 59.9 & 37.3 & 2.7 \\
\hline
\end{tabular}


TABLE 36

CORRELATION BETWEEN PARENTAL OPINION AS TO THE IMPORTANCE OF

THEIR CHILDREN MARRYING AN ADVENTIST AND THE CATEGORY OF MARRIAGE PARTNER

\begin{tabular}{|c|c|c|c|c|}
\hline \multirow[b]{2}{*}{$\begin{array}{c}\text { Categories of Marriage } \\
\text { Partner }\end{array}$} & \multirow[b]{2}{*}{$\begin{array}{l}\text { Number of } \\
\text { Responses }\end{array}$} & \multicolumn{3}{|c|}{ Percentage of Total } \\
\hline & & $\begin{array}{l}\text { Very Important-- } \\
\text { Strongly Oppose } \\
\text { Marriage to a Non- } \\
\text { Member. }\end{array}$ & $\begin{array}{l}\text { Very Important-- } \\
\text { but Would Leave } \\
\text { the Decision to } \\
\text { the Children. }\end{array}$ & $\begin{array}{l}\text { Not too Important-- } \\
\text { their Happiness } \\
\text { is the Most Im- } \\
\text { portant. }\end{array}$ \\
\hline Husband & 578 & 57.3 & 39.3 & 3.4 \\
\hline Wife & 574 & 62.8 & 35.1 & 2.1 \\
\hline No answer & 3 & 33.3 & 66.7 & -- \\
\hline TOTAL & 1155 & & & \\
\hline MEAN PERCENTAGE & & 59.9 & 37.3 & 2.7 \\
\hline
\end{tabular}


TABLE 37

CORRELATION BETWEEN PARENTAL OPINION AS TO THE IMPORTANCE OF

THEIR CHILDREN MARRYING AN ADVENTIST AND THE

ADVENTIST BACKGROUND OF PARENTS

\begin{tabular}{|c|c|c|c|c|}
\hline \multirow[b]{2}{*}{$\begin{array}{c}\text { Adventist Background } \\
\text { of Parents }\end{array}$} & \multirow[b]{2}{*}{$\begin{array}{l}\text { Number of } \\
\text { Responses }\end{array}$} & \multicolumn{3}{|c|}{ Percentage of Total } \\
\hline & & $\begin{array}{l}\text { Very Important-- } \\
\text { Strongly oppose } \\
\text { Marriage to a Non- } \\
\text { Member. }\end{array}$ & $\begin{array}{l}\text { Very Important-- } \\
\text { but Would Leave } \\
\text { the Decision to } \\
\text { the Children. }\end{array}$ & $\begin{array}{l}\text { Not too Important-- } \\
\text { Their Happiness } \\
\text { is the Most Im- } \\
\text { portant. }\end{array}$ \\
\hline $\begin{array}{l}\text { No background, first- } \\
\text { generation Adventist }\end{array}$ & 762 & 57.9 & 39.5 & 2.6 \\
\hline $\begin{array}{l}\text { Second-generation } \\
\text { Adventist }\end{array}$ & 173 & 64.2 & 32.4 & 3.5 \\
\hline $\begin{array}{l}\text { Third- or fourth- gen- } \\
\text { eration Adventist }\end{array}$ & 40 & 82.5 & 15.0 & 2.5 \\
\hline No answer & 11 & 54.6 & 45.4 & --- \\
\hline TOTAL & 986 & & & \\
\hline MEAN PERCENTAGE & & 59.9 & 37.3 & 2.7 \\
\hline
\end{tabular}


TABLE 38

CORRELATION BETWEEN PARENTAL OPINION AS TO THE IMPORTANCE OF

THEIR CHILDREN MARRYING AN ADVENTIST AND THE

REGULARITY OF FAMILY WORSHIP

\begin{tabular}{|c|c|c|c|c|}
\hline \multirow[b]{2}{*}{$\begin{array}{l}\text { Degree of Regularity } \\
\text { in Conducting } \\
\text { Family Worship }\end{array}$} & \multirow[b]{2}{*}{$\begin{array}{l}\text { Number of } \\
\text { Responses }\end{array}$} & \multicolumn{3}{|c|}{ Percentage of Total } \\
\hline & & $\begin{array}{l}\text { Very Important-- } \\
\text { Strongly Oppose } \\
\text { Marriage to a Non- } \\
\text { Member. }\end{array}$ & $\begin{array}{l}\text { Very Important-- } \\
\text { but Would Leave } \\
\text { the Decision to } \\
\text { the Children. }\end{array}$ & $\begin{array}{l}\text { Not too Important-- } \\
\text { their Happiness } \\
\text { is the Most Im- } \\
\text { portant. }\end{array}$ \\
\hline $\begin{array}{l}\text { Never have family } \\
\text { worship }\end{array}$ & 107 & 35.5 & 52.3 & 12.2 \\
\hline $\begin{array}{l}\text { Sometimes have family } \\
\text { worship }\end{array}$ & 350 & 54.9 & 42.9 & 2.3 \\
\hline $\begin{array}{l}\text { Have family worship } r \\
\text { ularly in morning }\end{array}$ & 244 & 67.6 & 30.7 & 1.6 \\
\hline $\begin{array}{l}\text { Have family worship } r \\
\text { ularly in evening }\end{array}$ & 67 & 62.7 & 37.3 & --- \\
\hline $\begin{array}{l}\text { Have family worship } r \\
\text { ularly both morning } \\
\text { and evening }\end{array}$ & 195 & 72.3 & 27.2 & .5 \\
\hline No answer & 23 & 56.5 & 39.1 & 4.4 \\
\hline TOTAL & 986 & & & \\
\hline MEAN PERCENTAGE & & 59.9 & 37.3 & 2.7 \\
\hline
\end{tabular}


Over 12.2 percent who conducted no family worship felt that marrying within the church was not necessarily important as long as the children were happy.

The number of volumes of the Spirit of Prophecy in the home clearly relates to this question. Table 39 indicates that those families which had three or fewer volumes showed a rather large percentage of parents who felt that the happiness of the marriage should take precedence over the religious beliefs of the marriage partner.

In comparing these attitudes of the parents toward marriage with those of Adventist young people (see table 108), the young people were even more strongly opposed to marriage with non-members than were their parents. A total of 62 percent stated that they would never consent to marry a non-member. However, 27.1 percent reported that although they agreed that it was very important to marry within the faith, they would not categorically rule out marriage to a non-member under certain circumstances.

Parental Opinion as to How Marriage Partners Should be Chosen

In the traditional Japanese family of former years, marriages were arranged by the family first in the best interests of the family, and second for the happiness of the young people involved. Recent years have seen great changes in Japan as to how the marriage partners are chosen. Seventh-day Adventist families were no exception in this respect. 
TABLE 39

CORRELATION BETWEEN PARENTAL OPINION AS TO THE IMPORTANCE OF

THEIR CHILDREN MARRYING AN ADVENTIST AND THE NUMBER

OF SPIRIT OF PROPHECY BOOKS IN HOME

\begin{tabular}{|c|c|c|c|c|}
\hline \multirow[b]{2}{*}{$\begin{array}{c}\text { Number of Spirit of } \\
\text { Prophecy Books in } \\
\text { the Home. }\end{array}$} & \multirow[b]{2}{*}{$\begin{array}{l}\text { Number of } \\
\text { Responses }\end{array}$} & \multicolumn{3}{|c|}{ Percentage of Total } \\
\hline & & $\begin{array}{l}\text { Very Important-- } \\
\text { Strong1y Oppose } \\
\text { Marriage to a Non- } \\
\text { Member. }\end{array}$ & $\begin{array}{l}\text { Very Important-- } \\
\text { but Would Leave } \\
\text { the Decision to } \\
\text { the Children. }\end{array}$ & $\begin{array}{l}\text { Not too Important-- } \\
\text { their Happiness } \\
\text { is the Most Im- } \\
\text { portant. }\end{array}$ \\
\hline None & 13 & 38.5 & 53.9 & 7.7 \\
\hline $1-3$ volumes & 47 & 19.2 & 61.7 & 19.2 \\
\hline 4-10 volumes & 216 & 46.3 & 50.0 & 3.7 \\
\hline More than 10 volumes & 704 & 67.6 & 31.1 & 1.3 \\
\hline No answer & 6 & 16.7 & 83.3 & -- \\
\hline TOTAL & 986 & & & \\
\hline MEAN PERCENTAGE & & 59.9 & 37.3 & 2.7 \\
\hline
\end{tabular}


By a wide margin, as shown in table 40 , Adventist parents agreed that although the choice should be made by the young people involved, the parents' wishes should be consulted and their approval secured. Only 2.3 percent of the respondents felt that the choice was entirely up to the young people involved, and an even smaller percentage, 1.5 percent, felt that it was the right and duty of the parents alone to choose the marriage partner.

TABLE 40

PARENTAL OPINION AS TO METHOD OF CHOOSING CHILDREN'S MARRIAGE PARTNER

\begin{tabular}{lcc}
\hline Categories of Parental opinion & $\begin{array}{c}\text { Number of } \\
\text { Responses }\end{array}$ & $\begin{array}{c}\text { Percentage } \\
\text { of Total }\end{array}$ \\
\hline $\begin{array}{l}\text { Children should make their own } \\
\text { choice of partner. }\end{array}$ & 23 & 2.3 \\
$\begin{array}{l}\text { Children should make their own } \\
\text { choice but with approval of } \\
\text { parents. }\end{array}$ & 894 & 88.5 \\
$\begin{array}{l}\text { Parents should have the right } \\
\text { to veto any choice of children. }\end{array}$ & 78 & 7.7 \\
$\begin{array}{l}\text { Parents should make the choice } \\
\text { of marriage partner for children. }\end{array}$ & 15 & 100.0 \\
\hline \begin{tabular}{l} 
Total \\
\hline
\end{tabular} & 1010 & \\
\hline
\end{tabular}

Table 105 indicates how single young people felt about this subject. By an almost identical percentage, they agreed with their parents that the choice was up to them but that they should seek the advice and approval of their parents. A larger percentage of young men than young women felt that the person involved should make the 
decision without the parents approval. Similarly, by an even smaller margin, young Adventist women more than young men felt that the decision was up to the parents alone.

\section{Attendance of Children from Adventist Homes at Religious Services}

Just how successful were Japanese Seventh-day Adventist parents in stimulating their children, especially after they had left home, to attend religious services? And what was the difference in this respect between divided homes and united Adventist families? Table 41 and figure 2 indicate answers to these questions.

Although the population of the children of divided families involved in the study was too small to give an exact comparison, trends may be evident. The following trends may be noticed:

1. In nearly every category there was a larger percentage of girls than boys attending religious services. This was true among the children of united families as well as those of divided homes.

2. During the early years, attendance was fairly high, but after leaving home, the children attended fewer and fewer services.

3. Children of united families showed a higher rate of church-service attendance than did those of divided families.

4. The influence of the Adventist parent, even in the divided home, was felt long after the children had left home. This was especially noted in the large number of women from these homes who attended Adventist church services.

The statistics exhibited in table 41 present a great challenge to Adventist parents and to the Adventist church as a 
whole. If the Adventist church is to be strengthened and used to reach out to non-Adventist relatives and neighbors, it must successfully address itself to the challenge of strengthening those influences that will help to win the children of Adventist homes to God and to the church. It must also seek to insulate against and weaken those influences that will tend to lead children away from God and the church. Chapter VII investigates the topic of religion and the Adventist family. 
TABLE 41

ATTENDANCE AT SERVICES OF THE CHURCH BY CHILDREN OF ADVENTIST FAMILIES

\begin{tabular}{|c|c|c|c|c|c|c|c|c|}
\hline \multirow{3}{*}{$\begin{array}{l}\text { Age Categories } \\
\text { of Children }\end{array}$} & \multicolumn{4}{|c|}{ United Families } & \multicolumn{4}{|c|}{ Divided Families } \\
\hline & \multicolumn{2}{|c|}{ Male } & \multicolumn{2}{|c|}{ Female } & \multicolumn{2}{|c|}{ Male } & \multicolumn{2}{|c|}{ Female } \\
\hline & Number & Percent & Number & Percent & Number & Percent & Number & Percent \\
\hline Pre-school age $(0-5)$ & 112 & 91.1 & 123 & 93.9 & 8 & 100.0 & 4 & 100.0 \\
\hline $\begin{array}{l}\text { Primary-school age } \\
\quad(6-12)\end{array}$ & 115 & 92.0 & 115 & 97.5 & 3 & 25.0 & 8 & 57.1 \\
\hline $\begin{array}{l}\text { Middle-school age } \\
\quad(13-15)\end{array}$ & 52 & 86.7 & 30 & 93.8 & 4 & 80.0 & 7 & 63.6 \\
\hline $\begin{array}{l}\text { High-school age } \\
\quad(16-18)\end{array}$ & 25 & 92.6 & 31 & 83.8 & 1 & 16.7 & 4 & 66.7 \\
\hline College age (19-22) & 32 & 64.0 & 33 & 86.8 & 5 & 45.5 & 8 & 66.7 \\
\hline $\begin{array}{l}\text { Young-adult age } \\
\quad(23-35)\end{array}$ & 55 & 56.1 & 76 & 73.1 & 7 & 21.9 & 13 & .56 .5 \\
\hline $\begin{array}{l}\text { Middle age and above } \\
\text { ( } 36 \text { and over) }\end{array}$ & 15 & 41.7 & 27 & 71.1 & 1 & 16.7 & 6 & 75.0 \\
\hline TOTAL & 406 & & 435 & & 29 & & 50 & \\
\hline MEAN PERCENTAGE & & 78.2 & & 87.3 & & 36.3 & & 64.1 \\
\hline
\end{tabular}




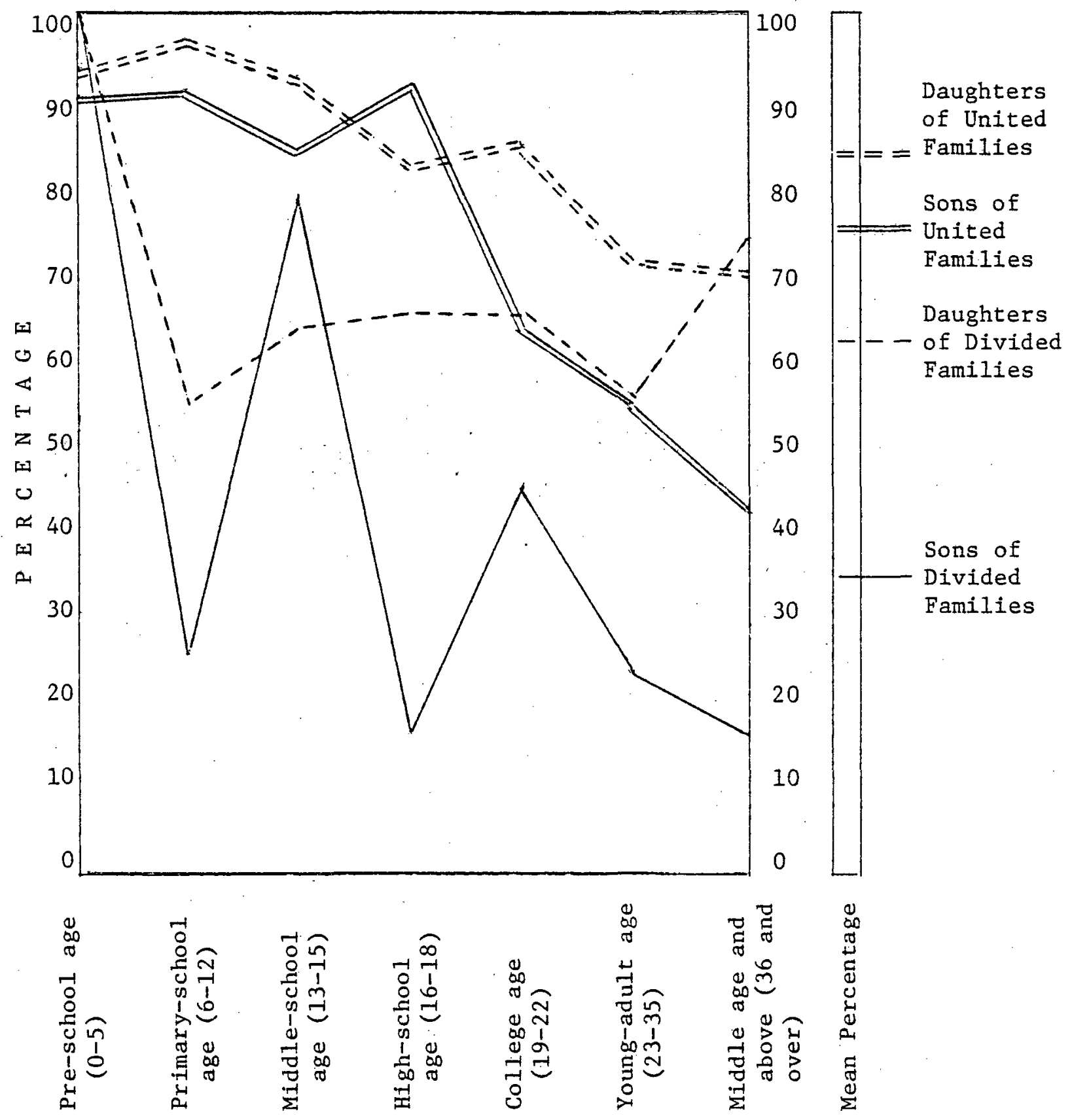

Fig. 2. Attendance at services of the church by the children of Adventist families. 


\section{CHAPTER VII}

\section{RELIGION IN THE FAMILY}

Any investigation of the Adventist family in Japan must seek to understand the religious dynamics at work in the home and to determine to what extent religion has affected the home. If the Adventist family is to become an effective instrument through which the religion of Jesus Christ is to influence the larger society about it, it must first of all be itself strongly influenced by that religion. What religious influences have helped to shape it, how deeply has Christianity affected it, what strengths and weaknesses does it demonstrate?. These are a few of the areas of concern that this section of the Adventist Family Survey sought to uncover.

\section{Religious Background of the Parental Home}

Table 42 gives an account of the religious background of the parental homes in which the respondents were born and grew to maturity. It indicated that by far the largest group, 64.7 percent, came from families with a Buddhist or other Japanese religious background. The second largest group, 17.7 percent, came from homes in which one or both parents were Adventists. What may appear surprising to some are the statistics that show that the smallest 
group, less than 5 percent of Adventist spouses of the united families, came from other Christian churches.

TABLE 42

RELIGIOUS BACKGROUND OF RESPONDENTS'

PARENTAL HOME

\begin{tabular}{|c|c|c|c|c|}
\hline \multirow{2}{*}{$\begin{array}{l}\text { Religion of } \\
\text { Parental Home }\end{array}$} & \multicolumn{2}{|c|}{ United Families } & \multicolumn{2}{|c|}{ Divided Families } \\
\hline & $\begin{array}{c}\text { Total } \\
\text { Responses }\end{array}$ & $\begin{array}{c}\text { Percentage } \\
\text { of Total }\end{array}$ & $\begin{array}{c}\text { Total } \\
\text { Responses }\end{array}$ & $\begin{array}{c}\text { Percentage } \\
\text { of Total }\end{array}$ \\
\hline No religion & 119 & 10.3 & 7 & 8.6 \\
\hline $\begin{array}{l}\text { Nominal Buddhist or } \\
\text { other Japanese .. } \\
\text { religion }\end{array}$ & 560 & 48.5 & 44 & 54.3 \\
\hline $\begin{array}{l}\text { Strict Buddhist or other } \\
\text { Japanese religion }\end{array}$ & 187 & 16.2 & 16 & 19.8 \\
\hline $\begin{array}{l}\text { Nominal non-Adventist } \\
\text { Christian }\end{array}$ & 30 & 2.6 & 3 & 3.7 \\
\hline $\begin{array}{l}\text { Strict non-Adventist } \\
\text { Christian }\end{array}$ & 25 & 2.2 & 1 & 1.2 \\
\hline One parent Adventist & 95 & 8.2 & 5 & 6.2 \\
\hline Both parents Adventists & 110 & 9.5 & 2 & 2.5 \\
\hline Other & 6 & .5 & -- & -- \\
\hline No answer & 23 & 2.0 & 3 & 3.7 \\
\hline TOTAL & 1155 & 100.0 & 81 & 100.0 \\
\hline
\end{tabular}

The divided families showed a similar spread in the religious backgrounds of the parental homes in which they were raised, but the number reporting that they had grown up in Buddhist homes was about 10 percent higher than that reported by united families. Divided 
families also showed less than half as many who came from an Adventist background.

As is seen in table 43, there were 5 percent more wives than husbands who reported a second or third generation Adventist background. Perhaps this indicates a greater responsiveness on the part of daughters as compared to sons to the religious influences of the home. A further investigation that could prove valuable would be one that investigates how many men and women, having grown up in Adventist homes, leave the church, why they leave, and who they are.

TABLE 43

ADVENTIST BACKGROUND OF PARENTAL HOME

\begin{tabular}{lccccc}
\hline \multirow{2}{*}{$\begin{array}{c}\text { Adventist } \\
\text { Background }\end{array}$} & $\begin{array}{c}\text { Husbands } \\
\text { Responses }\end{array}$ & $\begin{array}{c}\text { Percentage } \\
\text { of Total }\end{array}$ & $\begin{array}{c}\text { Total } \\
\text { Responses }\end{array}$ & $\begin{array}{c}\text { Percentage } \\
\text { of Total }\end{array}$ \\
$\begin{array}{l}\text { No background, } \\
\text { first-generation } \\
\text { Adventist }\end{array}$ & 468 & 81.0 & & 435 & 75.8 \\
$\begin{array}{l}\text { Second-generation } \\
\text { Adventist }\end{array}$ & 80 & 13.8 & & 110 & 19.2 \\
$\begin{array}{l}\text { Third- or fourth- } \\
\text { generation Ad- } \\
\text { ventist }\end{array}$ & 25 & 4.3 & & 20 & 3.5 \\
$\begin{array}{l}\text { No answer } \\
\text { Total }\end{array}$ & 5 & 100.0 & 574 & 100.1 \\
\hline
\end{tabular}


Family Worship in the Adventist Family

Families that pray together daily are said to stay together. They also demonstrate a meaningful commitment to their faith. Tables 44 through 47 deal with the degree of faithfulness of Adventist families in conducting worship in the home.

The figures indicate that two of every ten families had regular family worship both morning and evening. They also show that another three of ten families had regular worship either in the mornings or evenings. These families indicate by their regularity in family worship a meaningful commitment to their faith in Christ and a strong desire for His blessing on their family. It is of deep concern that 45 percent of the Adventist families stated either that they never had family worship or that they had it only sporadically.

TABLE 44

REGULARITY OF FAMILY WORSHIP

\begin{tabular}{lcc}
\hline & $\begin{array}{c}\text { Total } \\
\text { Responses }\end{array}$ & $\begin{array}{c}\text { Percentage } \\
\text { of Total }\end{array}$ \\
\hline Never have family worship & 132 & 11.4 \\
$\begin{array}{l}\text { Sometịmes have family worship } \\
\text { Have family worship regularly } \\
\text { in mornings }\end{array}$ & 391 & 33.9 \\
$\begin{array}{l}\text { Have family worship regularly } \\
\text { in evenings }\end{array}$ & 292 & 25.3 \\
$\begin{array}{l}\text { Have family worship regularly both } \\
\text { mornings and evenings }\end{array}$ & 74 & 6.4 \\
$\begin{array}{l}\text { No answer } \\
\text { Total }\end{array}$ & 238 & 20.6 \\
\hline
\end{tabular}


Table 45 records statistics by employment categories as to the degree of faithfulness in family worship. Adventist literature evangelists reported the highest degree of faithfulness in conducting family worship, 83.8 percent. They are followed by Adventist church employees, 63.0 percent of whom conducted regular family worship. When these two groups were omitted, the combined percentages of the rest of Adventist families who had regular worship in the home drops considerably to between 40 and 50 percent. This is an area which must be of concern to those who would strengthen the family and use it to win non-Christian family members and neighbors to Christ.

Table 46 shows to what extent, if any, the Adventist religious background affects the degree of regularity in having family worship. Contrary to what might be expected, there seems to be very little difference in whether the husbands and wives were first-generation Adventists with no Adventist background, or were raised in an Adventist home as either a second-or third-generation church member. Perhaps this indicates a certain laxness in the religious training of their parental home. Or perhaps it indicates a reaction to the practices of their childhood home.

of those responding to the question, "Who leads out in family worship?" the great majority, 67 percent, reported that the husband and father led out (see table 47). What is rather surprising is the 13.2 percent who responded that neither husband nor wife but some other person led out. When asked to tell who that other person was, a large number answered that one of the children led family worship. The researcher can testify from personal observation while 
TABLE 45

CORRELATION BETWEEN REGULARITY OF FAMILY WORSHIP AND EMPLOYMENT CATEGORIES OF MAJOR WAGE EARNER

\begin{tabular}{|c|c|c|c|c|c|c|}
\hline \multirow[b]{2}{*}{$\begin{array}{l}\text { Employment } \\
\text { ccategories }\end{array}$} & \multirow[b]{2}{*}{$\begin{array}{l}\text { Number of } \\
\text { Responses }\end{array}$} & \multicolumn{5}{|c|}{ Percentages of Total } \\
\hline & & $\begin{array}{c}\text { Never have } \\
\text { Family } \\
\text { Worship }\end{array}$ & $\begin{array}{l}\text { Sometimes } \\
\text { have Family } \\
\text { Worship }\end{array}$ & $\begin{array}{l}\text { Have Family } \\
\text { Worship Reg- } \\
\text { ularly--AM }\end{array}$ & $\begin{array}{l}\text { Have Family } \\
\text { Worship Reg- } \\
\text { ularly--PM }\end{array}$ & $\begin{array}{l}\text { Have Family } \\
\text { Worship Reg- } \\
\text { ularly--both } \\
\text { AM and PM }\end{array}$ \\
\hline Adventist church employee & 346 & 3.5 & 31.8 & 29.5 & 9.5 & 24.0 \\
\hline $\begin{array}{l}\text { Adventist literature } \\
\text { evangelist }\end{array}$ & 74 & 2.7 & 13.5 & 36.5 & 2.7 & 44.6 \\
\hline $\begin{array}{l}\text { Self-employed (not in- } \\
\text { cluding literature } \\
\text { evangelist }\end{array}$ & 276 & 17.0 & 39.1 & 19.6 & 2.9 & 18.5 \\
\hline Salaried--1argely skilled & 164 & 19.5 & 37.8 & 18.3 & 6.7 & 15.9 \\
\hline Salaried--largely manual & 130 & 13.8 & 32.3 & 31.5 & 7.7 & 12.3 \\
\hline Professional or managerial & 141 & 14.2 & 38.3 & 21.3 & 5.7 & 14.9 \\
\hline Other & 10 & ---- & $-\cdots$ & 70.0 & 10.0 & 20.0 \\
\hline No answer & 14 & 7.1 & 35.7 & 7.1 & 7.1 & 42.9 \\
\hline TOTAL & 1155 & & & & & \\
\hline MEAN PERCENTAGES & & 11.4 & 33.9 & 25.3 & 6.4 & 20.6 \\
\hline
\end{tabular}


TABLE 46

CORRELATION BETWEEN REGULARITY OF FAMILY WORSHIP AND THE ADVENTIST BACKGROUND OF PARENTAL HOME

\begin{tabular}{|c|c|c|c|c|c|c|}
\hline \multirow[b]{2}{*}{$\begin{array}{l}\text { Adventist } \\
\text { Background }\end{array}$} & \multirow[b]{2}{*}{$\begin{array}{l}\text { Number of } \\
\text { Responses }\end{array}$} & \multicolumn{5}{|c|}{ Percentage of Total } \\
\hline & & $\begin{array}{l}\text { Never have } \\
\text { Family Worship }\end{array}$ & $\begin{array}{c}\text { Sometimes } \\
\text { have Family } \\
\text { Worship }\end{array}$ & $\begin{array}{l}\text { Have Family } \\
\text { Worship Reg- } \\
\text { ularly - AM }\end{array}$ & $\begin{array}{l}\text { Have Family } \\
\text { Worship Reg- } \\
\text { ularly - PM }\end{array}$ & $\begin{array}{c}\text { Have Family } \\
\text { Worship Reg- } \\
\text { ularly-both } \\
\text { AM and PM }\end{array}$ \\
\hline $\begin{array}{l}\text { No background, first- } \\
\text { generation Adventist }\end{array}$ & 906 & 11.5 & 32.5 & 25.5 & 5.6 & 22.2 \\
\hline $\begin{array}{l}\text { Second-generation } \\
\text { Adventist }\end{array}$ & 190 & 10.0 & 40.5 & 24.2 & 8.9 & 13.7 \\
\hline $\begin{array}{l}\text { Third- or fourth- } \\
\text { generation Adventist }\end{array}$ & 45 & 11.1 & 28.9 & 31.1 & 8.9 & 20.0 \\
\hline
\end{tabular}


visiting many Japanese Adventist homes that this is so. Although there may be reasons for neither father nor mother leading out in family worship, it may indicate a shirking of a God-given responsibility and is less than ideal, particularly if worship is to be truly significant in the home.

TABLE 47

LEADERSHIP IN FAMILY WORSHIP

\begin{tabular}{lcc}
\hline $\begin{array}{l}\text { Leader of Family } \\
\text { Worship }\end{array}$ & $\begin{array}{c}\text { Total } \\
\text { Responses }\end{array}$ & $\begin{array}{c}\text { Percentage } \\
\text { of Total }\end{array}$ \\
\hline Husband usually & 685 & 67.0 \\
Wife usually & 111 & 10.8 \\
Others & 135 & 13.2 \\
No answer & 92 & 9.0 \\
\hline TOTAL & 1023 & 100.0
\end{tabular}

\section{Adventist Published Periodicals Read Regularly in Adventist Families}

The Seventh-day Adventist Church in Japan publishes two periodicals regularly. One of these, Signs of the Times, is designed largely with the general public in mind. The other, Adventist Life, is published primarily for Adventist church members. Tables 48 and 49 show to what extent these periodicals were being read by the Adventist families in the various employment categories.

That 72 percent of the families surveyed read both of these periodicals may indicate a high level of church commitment. However, in a rather small total population of Adventists in Japan, the fact 
that 28 percent read neither periodical or only one could mean that 2,257 Adventist church members were somewhat out of touch with church activities, church programs, and the religious thinking of the church as a whole.

TABLE 48

ADVENTIST PERIODICALS READ REGULARLY

\begin{tabular}{lcc}
\hline Adventist Periodicals & $\begin{array}{c}\text { Total } \\
\text { Responses }\end{array}$ & $\begin{array}{c}\text { Percentage } \\
\text { of Total }\end{array}$ \\
\hline Signs of the Times only & 104 & 9.0 \\
\hline Adventist Life only & 112 & 9.7 \\
Both of the above & 832 & 72.0 \\
Neither of the above & 69 & 6.0 \\
No answer & 38 & 3.3 \\
\hline TOTAL & 1155 & 100.0 \\
\hline
\end{tabular}

Table 49 indicates that Adventist literature evangelists show the highest percent, 95.9 , of Adventist families who read both periodicals. Adventist church employees came second with 82.4 percent. In other categories of employment the figures dropped to between 60 and 67 percent. This would indicate that there is considerable room for improvement in the promotion of these two church periodicals, which could lead to stronger Adventist families. 
TABLE 49

CORRELATION BETWEEN ADVENTIST PERIODICALS READ REGULARLY AND THE EMPLOYMENT CATEGORY OF MAJOR WAGE EARNER

\begin{tabular}{|c|c|c|c|c|c|}
\hline \multirow[b]{2}{*}{ Employment Gategory } & \multirow{2}{*}{$\begin{array}{l}\text { Number of } \\
\text { Responses }\end{array}$} & \multicolumn{4}{|c|}{ Percentages of Total } \\
\hline & & $\begin{array}{l}\text { "Signs of the } \\
\text { Times" Only }\end{array}$ & $\begin{array}{l}\text { "Adventist } \\
\text { Life" Only }\end{array}$ & $\begin{array}{l}\text { Both of the } \\
\text { Above }\end{array}$ & $\begin{array}{r}\text { Neither of } \\
\text { the Above }\end{array}$ \\
\hline Adventist church employee & 346 & 3.5 & 8.4 & 82.4 & 3.2 \\
\hline Adventist literature evangelist & 74 & --- & --- & 95.9 & --- \\
\hline $\begin{array}{l}\text { Self-employed (not including } \\
\text { literature evangelist) }\end{array}$ & 276 & 14.1 & 6.2 & 67.0 & 8.0 \\
\hline Salaried--largely skilled & 164 & 14.0 & 16.5 & 60.4 & 6.7 \\
\hline Salaried--1argely manual & 130 & 9.5 & 15.4 & 65.4 & 9.2 \\
\hline Professional or managerial & 141 & 12.1 & 12.8 & 63.1 & 7.8 \\
\hline Other & 10 & --- & 10.0 & 80.0 & 10.0 \\
\hline No answer & 14 & 14.3 & --- & 71.4 & 7.1 \\
\hline TOTAL & 1155 & & & & \\
\hline MEAN PERCENTAGE & & 9.0 & 9.7 & 72.0 & 6.0 \\
\hline
\end{tabular}




\section{Adventist Families and the \\ Writings of E. G. White}

One of the beliefs taught by Seventh-day Adventists is that, according to prophecies in Scripture, there will be a reappearance of the prophetic gift in the church preceeding the return of Christ to this earth. They believe that in Ellen G. White these prophecies found a partial fulfillment. The writings of Ellen White, directed to the church and to the world in general, are commonly known in the Adventist Church as the Spirit of Prophecy. Loyal Adventists in countries around the world are firm believers in her prophetic gift and consider her writings to be inspired counsel from God.

Table 50 discloses to what extent Adventist families in Japan had Mrs. White's writings in their own homes. These statistics do not indicate to what extent they had confidence in her as a spokeswoman for God nor to what extent they read the volumes which they owned. It does indicate that only a very small percentage had none of her books in their homes, and that the great majority, that is 70.1 percent, had more than ten volumes. It would also seem probable that some of those with only a limited number of these books in their homes were new members who had not yet purchased a greater number of them.

These statistics do seem to indicate that the church has been fairly successful in placing these books in the homes of Adventist members. No doubt much more can and should be done to see that these writings fulfill their place in strengthening the faith of the members of Adventist families. 
TABLE 50

VOLUMES OF E. G. WHITE WRITINGS IN THE HOME

\begin{tabular}{lcc}
\hline $\begin{array}{c}\text { Volumes of E. G. White } \\
\text { Writings }\end{array}$ & $\begin{array}{c}\text { Total } \\
\text { Response }\end{array}$ & $\begin{array}{c}\text { Percentage } \\
\text { of Total }\end{array}$ \\
\hline None & 20 & 1.7 \\
1-3 volumes & 58 & 5.0 \\
4-10 volumes & 356 & 22.2 \\
More than 10 volumes & 810 & 70.1 \\
No answer & 11 & 1.0 \\
\hline TOTAL & 1155 & 100.0 \\
\hline
\end{tabular}

Degree of Active Involvement in Local Church Leadership

Table 51 indicates to what extent the respondents were actively involved in local church leadership during the past two years. Of those responding, 75.1 percent of the husbands and 67.4 percent of the wives reported holding some church office during the previous two years. This would seem to indicate a rather high level of comitment to the church. By nearly 8 percent, more Adventist husbands had held offices than had their wives. This can be partially explained by the comparatively large number of the husbands who were employed by the church in pastoral duties or other positions of leadership in the church.

When church involvement of members is compared on the basis of the Adventist background of the husbands and wives, second- and thirdrgeneration Adventists showed a slightly higher degree of involvement in church leadership than those with no Adventist 
TABLE 51

CHURCH OFFICES HELD DURING THE PAST TWO YEARS

\begin{tabular}{lccccc}
\hline \multirow{2}{*}{$\begin{array}{c}\text { Church Offices } \\
\text { Held }\end{array}$} & Husbands' & Responses & & \multicolumn{2}{c}{ Wives' Responses } \\
\cline { 6 - 7 } & $\begin{array}{c}\text { Total } \\
\text { Responses }\end{array}$ & $\begin{array}{c}\text { Percentage } \\
\text { of Total }\end{array}$ & & $\begin{array}{c}\text { Total } \\
\text { Responses }\end{array}$ & $\begin{array}{c}\text { Percentage } \\
\text { of Total }\end{array}$ \\
\hline Have held none & 121 & 20.9 & & 156 & 27.2 \\
Have held some & 434 & 75.1 & & 387 & 67.4 \\
No answer & 23 & 4.0 & & 31 & 5.4 \\
\hline TOTAL & 578 & 100.0 & & 574 & 100.0 \\
\hline
\end{tabular}

background (see table 52). However, the fact that seven out of ten husbands and wives of Adventist families had held some local church office during the preceeding two years indicates a high degree of interest and participation in the church activities and its programs.

TABLE 52

CORRELATION BETWEEN INVOLVEMENT IN CHURCH LEADERSHIP DURING THE PAST TWO YEARS AND ADVENTIST BACKGROUND

\begin{tabular}{lccc}
\hline \multicolumn{1}{c}{$\begin{array}{c}\text { Degree of Adventist } \\
\text { Background }\end{array}$} & $\begin{array}{c}\text { Total } \\
\text { Responses }\end{array}$ & $\begin{array}{c}\text { Have not } \\
\text { held office }\end{array}$ & $\begin{array}{c}\text { Have held } \\
\text { Office }\end{array}$ \\
\hline $\begin{array}{l}\text { No background, first-generation } \\
\text { Adventist }\end{array}$ & 906 & 24.5 & 70.2 \\
$\begin{array}{l}\text { Second-generation Adventist } \\
\begin{array}{l}\text { Third- or more generation } \\
\text { Adventist }\end{array}\end{array}$ & 190 & 23.2 & 75.3 \\
TOTAL & 45 & 24.4 & 75.6 \\
$\begin{array}{l}\text { MEAN PERCENTAGE } \\
\text { MEAT }\end{array}$ & 1155 & & \\
\hline
\end{tabular}


Church Membership in Relationship

to Time of Marriage

Just when did the husband and wife of the Japanese Adventist families become church members? Was it before or after they entered into marriage? What percentage married outside the church but were successful in bringing their non-Adventist spouse into church fellowship? Table 53 records the responses of Adventist husbands and wives of united families to these questions. What effect, if any, these various incidents had on the happiness of the marriage will be noted in table 80 .

TABLE 53

TIME OF BECOMING AN ADVENTIST CHURCH MEMBER. IN RELATION TO TIME OF ENTERING MARRIAGE

\begin{tabular}{lcc}
\hline & $\begin{array}{c}\text { Total } \\
\text { Responses }\end{array}$ & $\begin{array}{c}\text { Percentage } \\
\text { of Total }\end{array}$ \\
\hline $\begin{array}{l}\text { Both husband and wife baptized } \\
\text { before marriage }\end{array}$ & 823 & 71.3 \\
$\begin{array}{l}\text { Both husband and wife baptized } \\
\text { after marriage }\end{array}$ & 240 & 20.8 \\
$\begin{array}{l}\text { Wife baptized before, and } \\
\text { husband after marriage } \\
\text { Husband baptized before, and } \\
\text { wife after marriage } \\
\text { No answer }\end{array}$ & 41 & 3.5 \\
\hline \begin{tabular}{l} 
Total \\
\hline
\end{tabular} & 115 & 3.4 \\
\hline
\end{tabular}


The largest percentage of respondents, 71.3 percent, indicated that they.were baptized before entering into marriage. In other words, both husband and wife were Adventist church members when married. One of five indicated that both husband and wife had heard the Adventist message and had entered Adventist church fellowship some time after their marriage.

of particular interest and worthy of further research is the fact that nearly 7 percent of all united Adventist family spouses had married a non-Adventist spouse and had seen their non-Adventist marriage partner become a church member. The percentage of Adventist men as compared to women in this category is almost identical. The countless examples of those who have married outside the church against the advice and counsel of their pastors and friends and who have lost out spiritually themselves lends support to the disapproval on the part of the church for such "mixed marriages." However, the fact that 80 individuals, or 6.9 percent of all Adventist family respondents (see table 53), became church members in spite of the frowns of the church and the odds against them and their partners should lead to a re-evaluation on the part of the church toward such troubled individuals and to a deeper concern for them and an understanding of the problems they face.

\section{Influences Leading to Adventist}

\section{Church Membership}

In order to discover how best to work through Japanese Adventist families to win non-Adventist family members and acquaintances to Christ, an understanding of how husbands and wives in present Adventist families were influenced to become church members is 
important. Tables 54 and 55 record the responses of united Adventist family husbands and wives concerning the greatest influence in relation to their becoming church members. Without a doubt, one of the greatest challenges facing the Christian church is how to appeal to a larger number of men. This is particularly true in Japan. It is especially interesting and important therefore to note the differences in the influences that led husbands and wives to their: conversions.

Table 54 shows that the four greatest influences for both men and women were the same. Listed in order they were: (1) the work of the pastor or other evangelistic worker, (2) Bible correspondence courses, (3) public evangelistic meetings, and (4) reading religious literature. However, a comparison between husbands' and wives' responses indicated that the wives were more greatly influenced by people--friends, spouses, parents, teachers, ministers, and so on. On the other hand, husbands were more likely to be influenced by religious literature, radio broadcasts, Bible correspondence courses, and public evangelism. It would seem from this that women were more easily influenced by people and that men study and research on their own.

Table 55 points out the differences in the influences that led to church membership for first-generation Adventists as compared to second- and third-generation Adventists. Those without an Adventist background listed the top five influences as: (1) the influence of the pastor, (2) Bible correspondence courses, (3) public evangelistic meetings, (4) reading religious literature, and 
TABLE 54

STRONGEST INFLUENCE IN BECOMING AN ADVENTIST MEMBER

\begin{tabular}{|c|c|c|c|c|}
\hline & \multicolumn{2}{|c|}{ Husbands' Responses } & \multicolumn{2}{|c|}{ Wives' Responses } \\
\hline & $\begin{array}{c}\text { Total } \\
\text { Responses }\end{array}$ & $\begin{array}{l}\text { Percentage } \\
\text { of Total }\end{array}$ & $\begin{array}{c}\text { Total } \\
\text { Responses }\end{array}$ & $\begin{array}{l}\text { Percentage } \\
\text { of Total }\end{array}$ \\
\hline Public evangelism & 188 & 14.3 & 159 & 12.2 \\
\hline $\begin{array}{l}\text { Reading religious } \\
\text { literature }\end{array}$ & 184 & 14.0 & 130 & 10.0 \\
\hline Influence of friend & 116 & 8.8 & 121 & 9.3 \\
\hline Influence of spouse & 62 & 4.7 & 65 & 5.0 \\
\hline Influence of parents & 87 & 6.6 & 98 & 7.5 \\
\hline Adventist education & 63 & 4.8 & 90 & 6.9 \\
\hline $\begin{array}{l}\text { Sabbath school, regular } \\
\text { or branch }\end{array}$ & 67 & 5.1 & 68 & 5.2 \\
\hline Radio broadcast & 30 & 2.3 & 24 & 1.8 \\
\hline $\begin{array}{l}\text { Bible correspondence } \\
\text { course }\end{array}$ & 191 & 14.5 & 178 & 13.7 \\
\hline $\begin{array}{l}\text { Pastor or other } \\
\text { evangelistic } \\
\text { worker's efforts }\end{array}$ & 248 & 18.8 & 278 & 21.3 \\
\hline Other & 70 & 5.3 & 75 & 5.8 \\
\hline No answer & 12 & .9 & 17 & 1.3 \\
\hline TOTAL & 1318 & 100.1 & 1303 & 100.0 \\
\hline
\end{tabular}




\section{TABLE 55}

CORRELATION BETWEEN STRONGEST INFLUENCE LEADING TO AN ADVENTIST CHURCH MEMBERSHIP AND ADVENTIST BACKGROUND

\begin{tabular}{|c|c|c|c|c|c|c|c|c|c|c|c|c|}
\hline \multirow[b]{2}{*}{$\begin{array}{c}\text { Degree of Adventist } \\
\text { Background }\end{array}$} & \multirow[b]{2}{*}{$\begin{array}{l}\text { Number of } \\
\text { Responses }\end{array}$} & \multicolumn{11}{|c|}{ Percentages of Total } \\
\hline & & 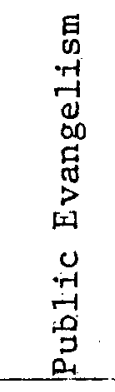 & 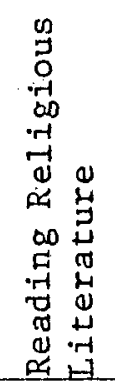 & 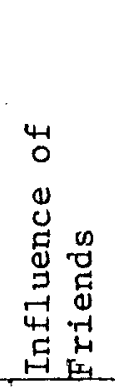 & 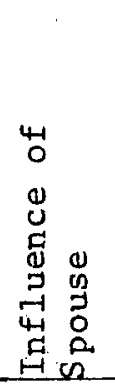 & 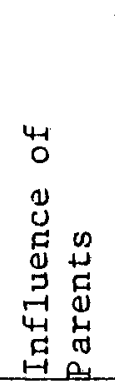 & 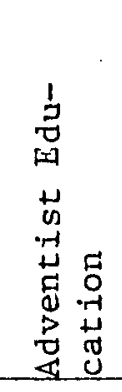 & $\begin{array}{l}-1 \\
0 \\
0 \\
0 \\
0 \\
0 \\
5 \\
5 \\
0 \\
0 \\
0 \\
0 \\
0 \\
0 \\
0\end{array}$ & 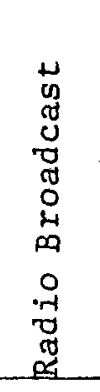 & 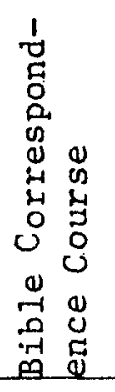 & 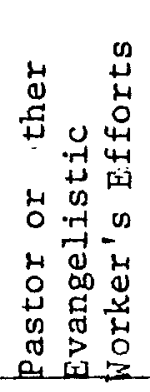 & 峜 \\
\hline $\begin{array}{l}\text { No background; first- } \\
\text { generation Adventist }\end{array}$ & 2074 & 15.1 & 13.0 & 10.6 & 5.7 & 1.1 & 3.1 & 4.9 & 2.2 & 15.7 & 21.8 & 5.7 \\
\hline $\begin{array}{l}\text { Second-generation } \\
\text { Adventist }\end{array}$ & 424 & 6.8 & 8.0 & 3.5 & 1.7 & 29.5 & 17.5 & 5.0 & 1.9 & 8.0 & 12.7 & 4.5 \\
\hline $\begin{array}{l}\text { Third- or more gen- } \\
\text { eration Adventist }\end{array}$ & 97 & 3.1 & 8.2 & 2.1 & 1.0 & 37.1 & 15.5 & 10.3 & 1.0 & 7.2 & 11.3 & 3.1 \\
\hline No answer & 31 & 9.7 & 6.5 & 6.5 & 3.2 & 3.2 & --- & 9.7 & -- & 12.9 & 32.3 & 12.9 \\
\hline TOTAL & 2626 & & & & & & & & & & & \\
\hline MEAN PERCENTAGE & & 13.3 & 12.0 & 9.1 & 4.8 & 7.0 & 5.8 & 5.1 & 2.1 & 14.1 & 20.1 & 5.5 \\
\hline
\end{tabular}


(5) the influence of Adventist friends. By contrast, second- and third-generation Adventists 1isted parents, Adventist education, their pastor, the Sabbath School, and reading religious 1iterature as primary influences in their becoming members.

Although table 55 gives only the percentages in each of the categories of influence, it is interesting and significant to change these percentages to numbers of individuals. For instance, the 3.1 percent of the first-generation Adventists who became members largely because of Christian education represents sixtyfour individuals. By comparison, the 15.5 percent of the thirdgeneration Adventists represents only fifteen individuals. And the 4.9 percent of the first generation who became members because of the Sabbath School represents 102 individuals as compared to the 10.3 percent of the third generation which represents only ten individuals.

\section{Attitudes Toward the Teachings Concerning}

Healthful Living

Seventh-day Adventists believe that healthful living is not merely a concern with healthy bodies and a long, sickness-free life. Believing as they do in the indivisibility of man's body, soul, and spirit, they teach that healthful living is a spiritual responsibility of those desiring a closer communion with God. They also believe that divine counsel concerning healthful living has come to the church through the writings of Ellen G. White.

Tables 56 and 57 indicate to what extent Japanese Adventist families accepted these teachings and conducted their lives in 
harmony with them. Some differences were noted in the responses of divided families from those of united families. Whereas 72.1 percent of the united families accepted these teachings and gladly lived in harmony with them, 59.3 percent of the divided families did so. A surprisingly small percentage of the united families, only twenty-four individuals of $1,155,2.1$ percent, stated that they did not understand the reasons for the healthful-living principles and teachings. Nearly three times that percentage of the divided families did not understand the principles of healthful 1iving clearly.

TABLE 56

ATTITUDE TOWARD THE ADVENTIST HEALTH MESSAGE

\begin{tabular}{|c|c|c|c|c|}
\hline & \multicolumn{2}{|c|}{ United Families } & \multicolumn{2}{|c|}{ Divided Families } \\
\hline 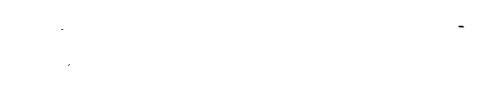 & $\begin{array}{c}\text { Total } \\
\text { Responses }\end{array}$ & $\begin{array}{l}\text { Percentage } \\
\text { of Total }\end{array}$ & $\begin{array}{c}\text { Total } \\
\text { Responses }\end{array}$ & $\begin{array}{c}\text { Percentage } \\
\text { of Total }\end{array}$ \\
\hline $\begin{array}{l}\text { Gladly live in harmony } \\
\text { with it. }\end{array}$ & 833 & 72.1 & 48 & 59.3 \\
\hline $\begin{array}{l}\text { Understand it but do } \\
\text { not follow it. }\end{array}$ & 205 & 17.7 & 20 & 24.7 \\
\hline $\begin{array}{l}\text { Do not really under- } \\
\text { stand it clearly. }\end{array}$ & 24 & 2.1 & 5 & 6.2 \\
\hline $\begin{array}{l}\text { Not interested or } \\
\text { concerned. }\end{array}$ & 6 & .5 & -- & --- \\
\hline No answer & 87 & 7.5 & 8 & 9.9 \\
\hline TOTAL & 1155 & 99.9 & 81 & 100.0 \\
\hline
\end{tabular}


One half of one percent expressed no interest or concern in the subject. If these percentages are an accurate indication of the church as a whole, it would seem that the Adventist church in Japan was quite successful in its endeavor to make healthful living an integral part of Seventh-day Adventist teachings. However, the 17.7 percent of the united families and the 24.7 percent of the divided family spouses who reported that they understood the teachings but for one reason or another were not following them suggests room for improvement. There seems to be a need for some type of motivation that is more than, mere knowledge or information.

Still another area of concern can be seen in tajle 57 which analyzes the attitudes and practices of first-, second-, and thirdgeneration Adventists toward the health message. Not only do the figures indicate that the percentages of those who were gladly living in harmony with Adventist health principles dropped from 73.1 to 70.0 to 64.4 percent in inverse proportion to the degree of their Adventist background, but those expressing no interest at al1 increased from .2 percent for first-generation Adventists to 1.6 percent among second-generation Adventists and 2.2 percent among those who were third- or more generation Adventists. While the numbers involved may be too small for conclusive results, it may indicate that, to some extent, familiarity had bred contempt among some of these genetic Adventists.

\section{Influences Affecting Spiritual Growth}

Strengthening the Japanese Adventist family must also involve the inner development and growth of the spiritual life of 
TABLE 57

CORRELATION BETWEEN ATTITUDE TOWARD THE ADVENTIST HEALTH MESSAGE AND ADVENTIST BACKGROUND

\begin{tabular}{|c|c|c|c|c|c|}
\hline \multirow{2}{*}{$\begin{array}{c}\text { Degree of Adventist } \\
\text { Background }\end{array}$} & \multirow{2}{*}{$\begin{array}{l}\text { Number of } \\
\text { Responses }\end{array}$} & \multicolumn{4}{|c|}{ Percentage of Total } \\
\hline & & $\begin{array}{c}\text { Gladly Live } \\
\text { in Harmony } \\
\text { with It. }\end{array}$ & $\begin{array}{c}\text { Understand It, } \\
\text { but do not } \\
\text { Follow It. }\end{array}$ & $\begin{array}{c}\text { Do not Rea11y } \\
\text { Understand It } \\
\text { Clear1y. }\end{array}$ & $\begin{array}{l}\text { Not Interested } \\
\text { or Concerned. }\end{array}$ \\
\hline $\begin{array}{l}\text { No background, first- } \\
\text { generation Adventist }\end{array}$ & 906 & 73.1 & 16.8 & 2.2 & .2 \\
\hline $\begin{array}{l}\text { Second-generation } \\
\text { Adventist }\end{array}$ & 190 & 70.0 & 22.1 & 1.1 & 1.6 \\
\hline $\begin{array}{r}\text { Third- or more gen- } \\
\text { eration Adventist }\end{array}$ & 45 & 64.4 & 17.8 & 4.4 & 2.2 \\
\hline No answer & 14 & 64.3 & 21.4 & $-\cdots$ & $-\infty$ \\
\hline TOTAL & 1155 & & & & \\
\hline MEAN PERCENTAGE & & 72.1 & 17.7 & 2.1 & .5 \\
\hline
\end{tabular}


both the husband and the wife. Just which influences were most effective for the husband and which most effective for the wife are noted in table 58 .

Personal daily devotions headed the list of strongest influences affecting the spiritual growth of both husband and wife. of special interest was the differing attitudes of men and women toward the pastor's sermon and the Sabbath School class as aides to spiritual development.

of the husbands who responded, 20.5 percent indicated that they had gained slightly more from the Sabbath School class, while 19.3 percent felt the pastor's sermons were the greatest infiuence on their spiritual growth. On the other hand, 23.0 percent of the wives reported receiving a greater blessing from the sermon, and 18.0 percent felt the Sabbath School class brought them the greatest help.

A similar trend was reported by single, Adventist young people (see table 104). More young, single Adventist women than young men listed the pastor's sermon as the strongest influence in their spiritual growth, 22.9 percent as compared to 16.0 percent. On the other hand, 12.0 percent of the men favored the Sabbath School class as compared to only 8.6 percent for the single women. Those figures indicated a difference in the responses of men and women, a difference that was also noted by Dr. G. Oosterwal, of Andrews University, Berrien Springs, Michigan, who made a similar study of Seventh-day Adventist church members in a limited area of 
North America around the Great Lakes. According to his figures, ${ }^{1}$ the pastor's sermon appealed to women more than to men by 54 percent to 44 percent. In contrast, the Sabbath School class influenced men more than women by 56 percent to 50 percent.

\section{TABLE 58}

MOST HELPFUL INFLUENCES IN THE DEVELOPMENT OF SPIRITUAL LIFE

\begin{tabular}{|c|c|c|c|c|}
\hline & \multirow{2}{*}{ 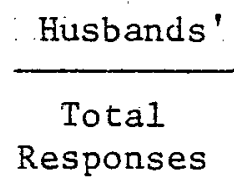 } & \multirow{2}{*}{ 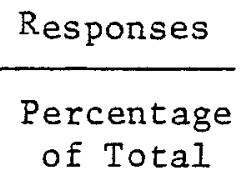 } & \multicolumn{2}{|c|}{ Wives' Responses } \\
\hline & & & $\begin{array}{c}\text { Total } \\
\text { Responses }\end{array}$ & $\begin{array}{c}\text { Percentage } \\
\text { of Total }\end{array}$ \\
\hline Sabbath sermon & 317 & 19.3 & 386 & 23.0 \\
\hline Sabbath school class & 336 & 20.5 & 303 & 18.0 \\
\hline Prayer meeting & 152 & 9.3 & 151 & 9.0 \\
\hline Private daily devotions & 370 & 22.5 & 423 & 25.2 \\
\hline Religious radio programs & 18 & 1.1 & 15 & .9 \\
\hline Reading religious books & 365 & 22.2 & 345 & 20.5 \\
\hline Counseling with pastor & 27 & 1.6 & 17 & 1.0 \\
\hline Other & 43 & 2.6 & 27 & 1.6 \\
\hline No answer & 15 & .9 & 14 & .8 \\
\hline TOTAL & 1643 & 100.0 & 1681 & 100.0 \\
\hline
\end{tabular}

These statistics may indicate that women were more ready to accept as authoritative the messages presented by the preacher. Men, on the other hand, tended to be more critical. The statistics also

${ }^{1}$ Gottfried Oosterwal, Patterns of SDA Church Growth in America (Berrien Springs, Mich., 1976), p. 57. 
seemed to show that men enjoyed the greater opportunity to react and become involved. These differing attitudes of men and women should be taken into account as plans are laid to attract and hold more men in the church.

\section{Maintaining Church Standards in the Home}

The standards of behavior set by the Adventist Church are high in comparison to that of many of the main-1ine churches. Some areas seen by Adventist spouses as presenting problems are noted in table 59 .

It must be noted first of all that more than half of the respondents failed to answer this question. This could mean one of several things. Perhaps it indicated that the respondents felt no particular problem regarding the maintenance of Christian standards in their home. Or it could mean that the question as printed in the survey instrument was unclear. It could also mean that the readers did not want to answer the question.

A total of 32.7 percent of the respondents stated that television in some form or another was the greatest problem in maintaining standards. When these figures are adjusted to include only those who answered this particular question, it indicates that 71.7 percent felt that television was a problem in their homes. Some of these indicated that they felt the problem was in the content of the program. However, the largest percentage wrote in comments that they felt the greatest problem was in the amount of time involved. A more precise instrument needs to be designed in the future to probe into this important area of Adventist family life. 
TABLE 59

PROBLEM AREAS IN HOME CONCERNING MAINTENANCE OF STANDARDS

\begin{tabular}{lcc}
\hline \hline & $\begin{array}{c}\text { Total } \\
\text { Responses }\end{array}$ & $\begin{array}{c}\text { Percentage } \\
\text { of Total }\end{array}$ \\
\hline Television programs & 378 & 32.7 \\
Reading matter & 7 & .6 \\
Music & 7 & .6 \\
Sports & 5 & .4 \\
Other & 130 & 11.3 \\
No answer & 628 & 54.4 \\
\hline ToTAL & 1155 & 100.0 \\
\hline
\end{tabular}

Adventist Church Member's Degree of Faithfulness to the Church

To what extent, in the spring of 1976, were the 8,069. Seventhday Adventist church members in Japan faithful to their church? Pastors of ten representative churches, some from each of the six districts into which the church was divided, evaluated the 1,776 members in these sample churches. Each pastor filled out a specially prepared evaluation biank, (see sample in appendix D). The members evaluated represented 22.0 percent of the total membership and included 26.7 percent of the Adventist families in Japan. The results of this membership faithfulness survey is seen in tables 60 and 61 and in figures 3 through 6.

Figure 3 indicates that there were nearly three female Adventist church members for every male menber. These statistics 


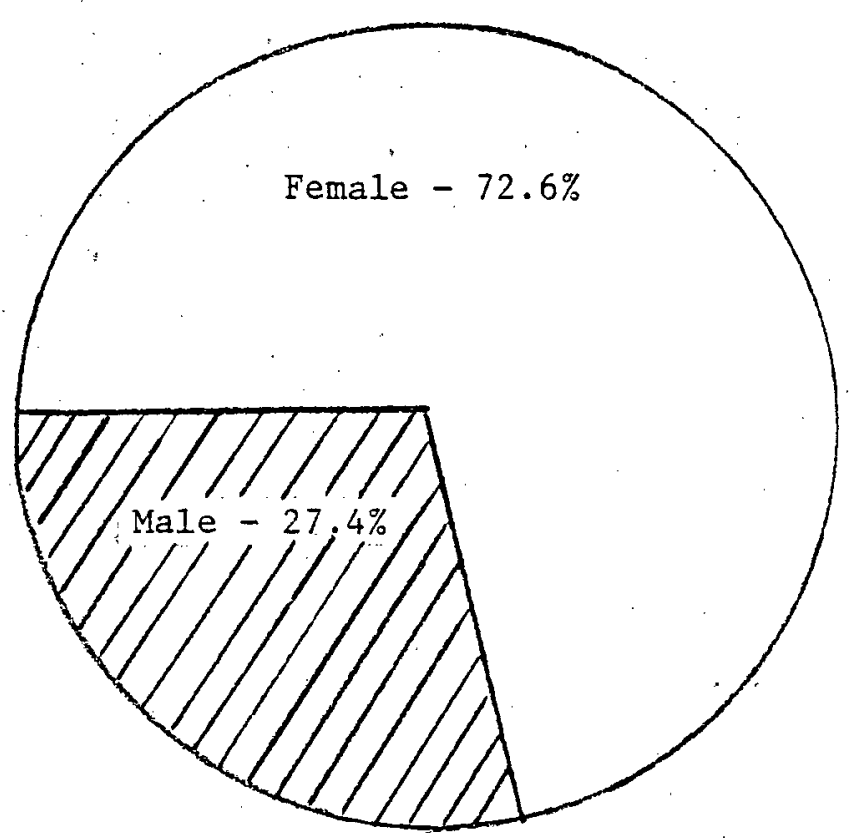

Fig. 3. Sex distribution of Adventist church members.

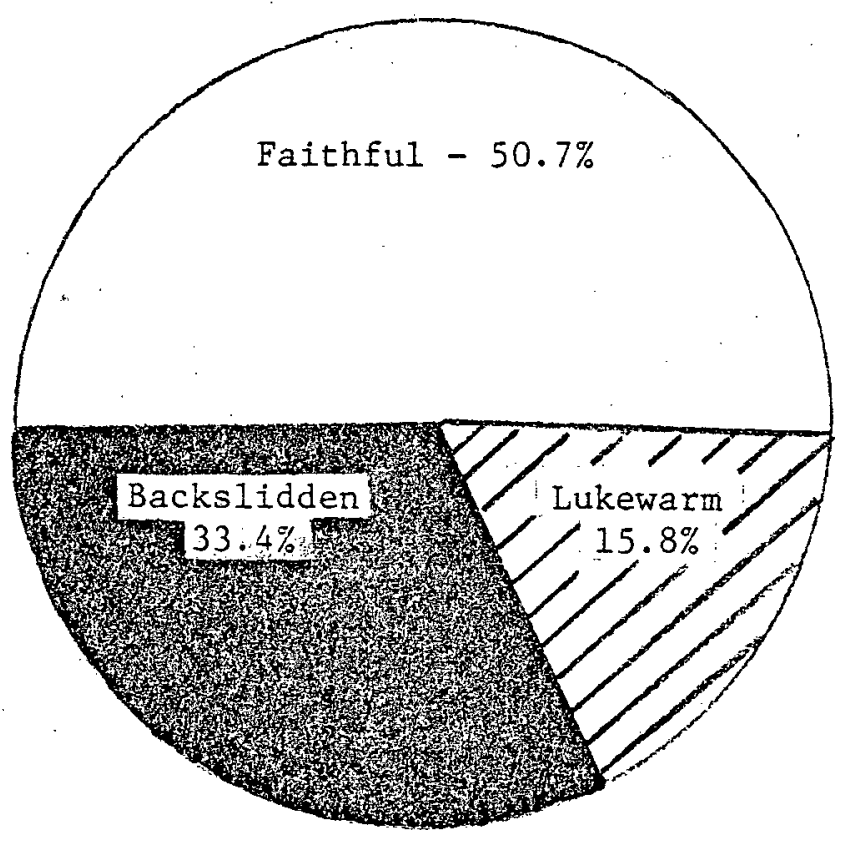

Fig. 4. Degree of faithfulness of church members as perceived by Adventist pastors. 
certainly need careful study if the number of Adventist families is to be increased.

Figure 4 indicates the degree of faithfulness of the members as evaluated by their pastors. Just a shade over 50 percent of the sample was considered very faithful, attending services except for sickness or other unusual circumstances. One of three of the members was judged by the pastors to be a backslidder, neither attending services nor supporting the church by his influence or his means. This also is a figure that cannot be safely ignored if the Adventist church is to be strengthened.

Table 60 and figure 5 analyze, according to sex, the degree of faithfulness of the members. Although there is an indication of slightly less faithfulness on the part of men as compared to women, it is a rather small difference. According to the opinion of those pastors the researcher contacted personally, the greatest contributing factor to the unfaithfulness of women to the church was the insufficient number of men as prospective husbands. The reason for male unfaithfulness, they felt, was more complex. Further research as to the reasons for the large percentage of unfaithfulness among the members should be given high priority.

In table 61 and figure 6 the degree of faithfulness as related to whether or not the member was a part of a united family is shown. In other words, was faithfulness to the church effected by whether or not husband and wife were united in the church as compared with the husband or wife from divided homes? A rather high percentage, 65.2 percent, of husbands and wives of united 
TABLE 60

DEGREE OF FAITHFULNESS OF CHURCH MEMBERS ACCORDING TO SEX AS PERCEIVED BY ADVENTIST PASTORS

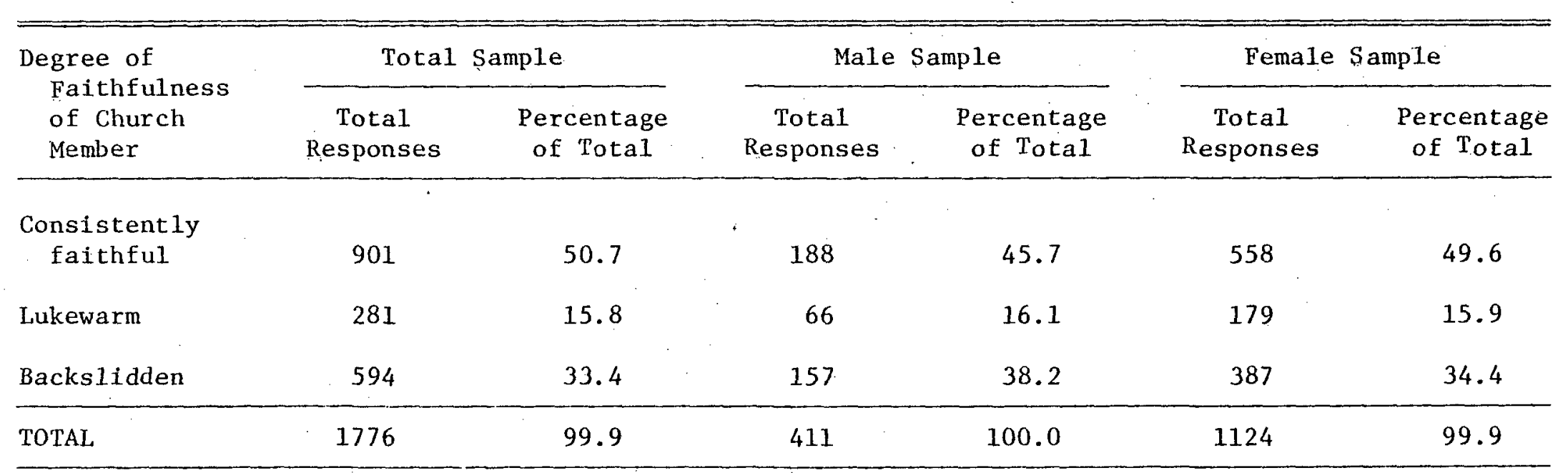



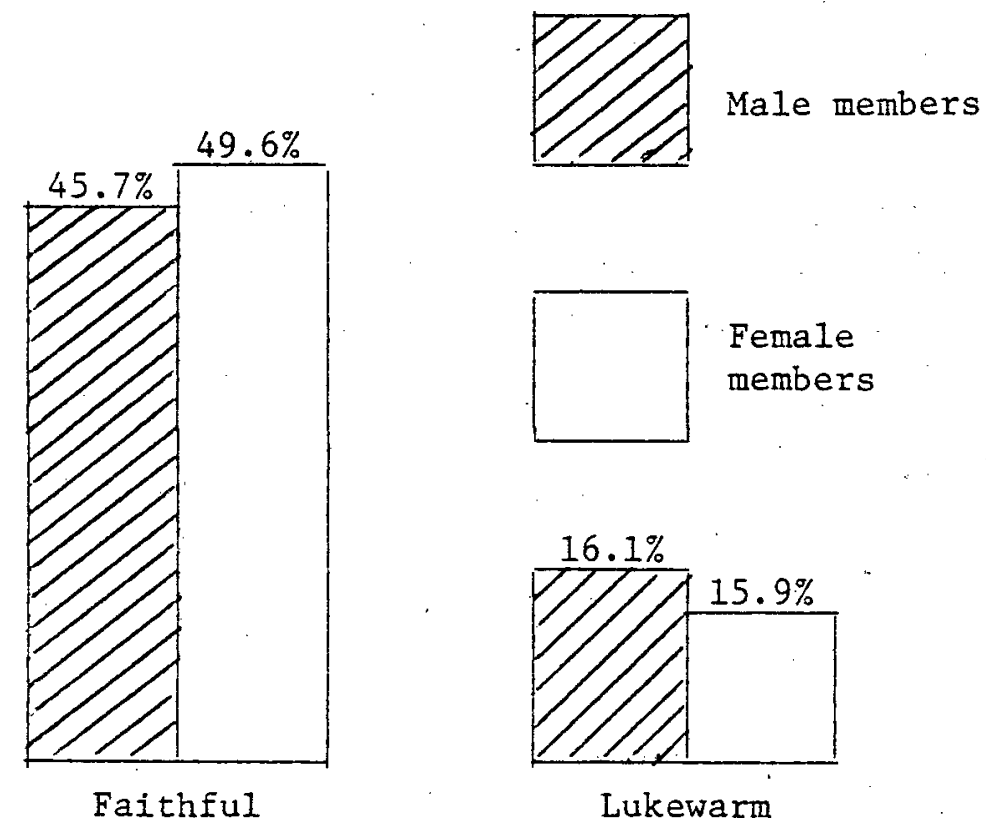

members
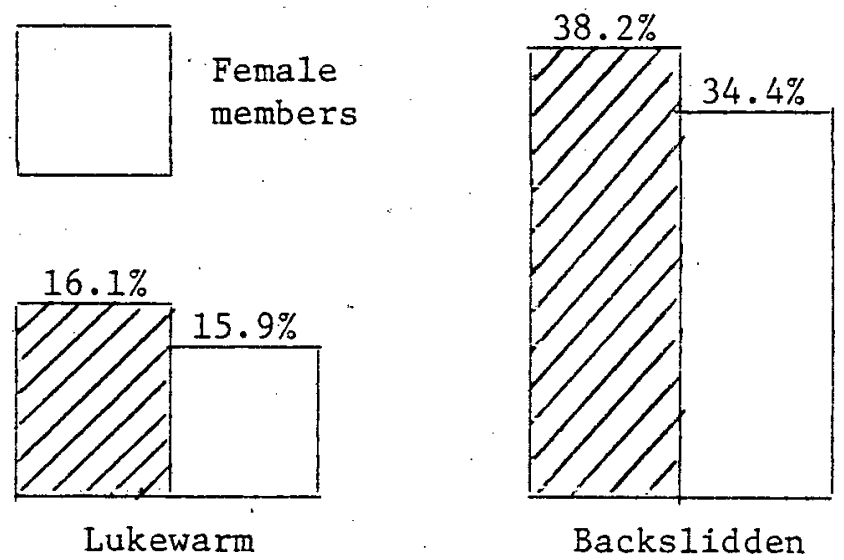

Fig. 5. Degree of faithfulness of church members according to sex as perceived by Adventist pastors. 
families were judged to be faithful. On the contrary, when the church member was not a part of a united family, that is, the member was unmarried, widowed, the spouse of a non-church member, and so forth, the rate of faithfulness to the church dropped to 45 percent. The backslider rate of the non-united family member was also considerably higher than for the united family member. These figures indicate the importance of making a concerted effort to unite families in the church. A greater interest should be made to secure the cooperation and interest of both marriage partners before acceptance into church membership. Particularly is this so in the light of the traditional Japanese characteristic which emphasizes group consciousness and group solidarity. These figures should also give church leaders added impetus to their efforts to bring the non-member spouse into church fellowship. Not only would this add to the church membership but it would tend to insure the present Adventist spouse's loyalty and faithfulness to the church.

\section{Attitude of the Non-Adventist Spouse in Divided Families Toward the Church.}

The primary survey instrument, The Seventh-day Adventist Family survey which was sent to all united Adventist family spouses, was also administered to a limited number of Adventist spouses of divided families in which either the husband or the wife was not a church member. Available statistics do not disclose just how many of these divided homes there are. However, eight-one responses from the Adventist spouse of these families gave an opportunity to 
TABLE 61

DEGREE OF FAITHFULNESS OF CHURCH MEMBERS AS PERCEIVED BY ADVENTIST PASTORS WHEN COMPARING SPOUSES OF

UNITED FAMILIES WITH OTHERS

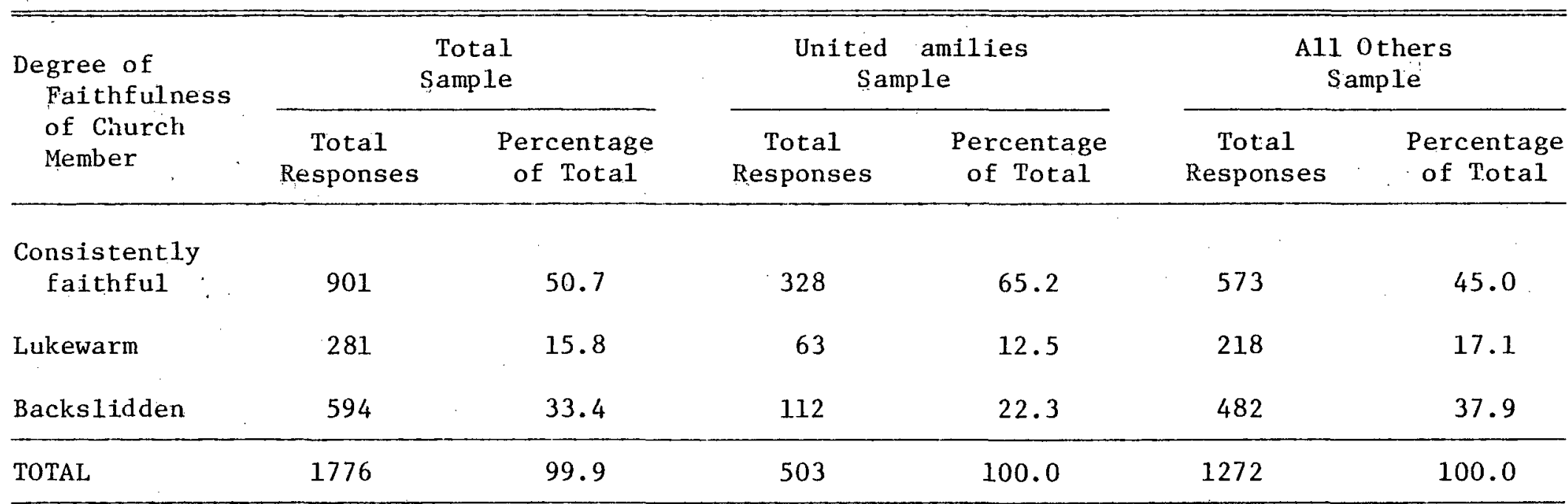

Note: The "United Families" columns show the degree of faithfulness of husbands and wives when both were church members. The "All other" columns show the degree of faithfulness of all church members other than the united families and includes the unmarried, those married to nonmembers, the divorced, the widowed, and so forth. 
$65.2 \%$

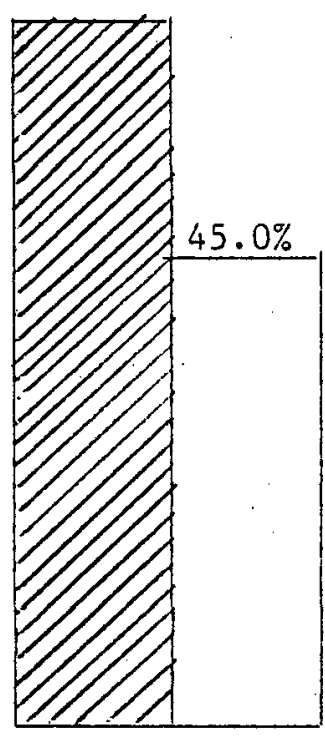

Faithful

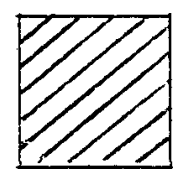

Both husband and wife members

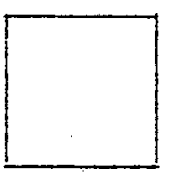

Al1 other members

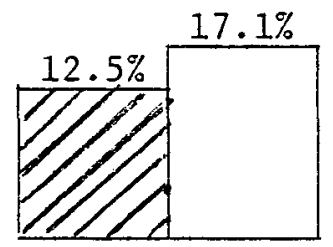

Lukewarm

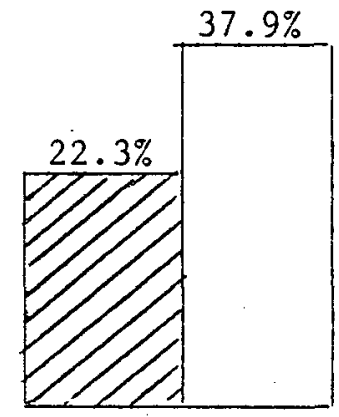

Backslidden

Fig. 6. Degree of faithfulness of church members as perceived by Adventist pastors when comparing spouses of united families with others.

Note: The "United Families" columns show the degree of faithfulness of husbands and wives when both were church members. The "A11 Other" columns show the degree of faithfulness of all church members other than the united families and includes such individuals as the unmarried, those married to non-members, divorced, widowed, and so forth. 
note similar and contrasting attitudes and behaviors reported by united family spouses.

In an attempt to discover the attitudes of non-Adventist spouses toward the church and to learn how they might best be won to Christ and the church, two additional questions were specifically directed to these divided-family Adventist spouses. Tables 62 through 66 show responses of the Adventist spouses to one of these questions, namely, "What is the attitude of your non-member spouse toward the Seventh-day Adventist church?"

As Eable 62 shows, six out of ten of these non-Adventist spouses were favorably impressed with their spouse's religious beliefs and showed an interest in the church. Less than two out of ten were opposed and about an equal number, while showing no interest themselves, did not oppose their spouses' practice of religion. These figures would seem to indicate a challenging field for investigation on the part of those interested in family evangelism.

Table 63 clearly shows that in those divided families where there was real happiness a large percentage of the non-member spouses were favorably impressed with the faith of his or her spouse. In those families where success and happiness were rated the highest, 76.2 percent of the non-member spouses showed an interest in the church. The figure dropped to 64.4 percent when the success was rated as relatively satisfactory, and to 22.2 percent when it was judged as relatively unsatisfactory. When the success and happiness of the home was rated as very unsatisfactory, not one of the non-member spouses showed any interest in the church. 
TABLE 62

NON-ADVENTIST SPOUSE'S ATTITUDE

TOWARD THE CHURCH

\begin{tabular}{lcc}
\hline \hline & $\begin{array}{c}\text { Total } \\
\text { Responses }\end{array}$ & $\begin{array}{c}\text { Percentage } \\
\text { of Total }\end{array}$ \\
\hline Strongly opposed & 7 & 8.6 \\
Somewhat opposed & 7 & 8.6 \\
$\begin{array}{l}\text { No interest in Christianity } \\
\text { but not opposed }\end{array}$ & 15 & 18.5 \\
$\begin{array}{l}\text { Somewhat interested } \\
\text { Strongly interested }\end{array}$ & 41 & 50.6 \\
No answer & 9 & 11.1 \\
\hline Total & 2 & 2.5 \\
\hline
\end{tabular}

Table 64 analyzes the non-members' attitude toward the church in relation to the degree of quarreling between the marriage partners. Here again a close relationship can be noted. Quarreling in itself did not seem to affect the interest in the church as Iong as the quarreling was not heated nor such a nature as to separate the closeness of the marriage partners. None of those who quarreled heatedly or who were silently antagonistic indicated any interest whatever in the faith of the member-spouse.

Although quite a large number of the spouses of these divided families failed to answer the question as to the degree of satisfaction with their sexual relationships in their marriage, table 65 indicates that of those who did respond and were very satisfied 66 percent of the non-member partners showed an interest 
TABLE 63

CORRELATION BETWEEN NON-ADVENTIST SPOUSE'S ATTITUDE TOWARD THE CHURCH AND EVALUATION OF SUCCESS AND HAPPINESS OF DIVIDED FAMILIES

\begin{tabular}{|c|c|c|c|c|c|c|}
\hline \multirow{2}{*}{$\begin{array}{l}\text { Evaluation of Success } \\
\text { and Happiness of } \\
\text { Marriage of } \\
\text { Divided Homes }\end{array}$} & \multirow{2}{*}{$\begin{array}{c}\text { Total } \\
\text { Responses }\end{array}$} & \multicolumn{5}{|c|}{ Percentage of Total } \\
\hline & & $\begin{array}{l}\text { Strongly } \\
\text { Opposed }\end{array}$ & $\begin{array}{r}\text { Somewhat } \\
\text { Opposed }\end{array}$ & $\begin{array}{l}\text { No Interest in } \\
\text { Christianity } \\
\text { but not opposed }\end{array}$ & $\begin{array}{l}\text { Somewhat } \\
\text { Interested }\end{array}$ & $\begin{array}{l}\text { Strongly } \\
\text { Interested }\end{array}$ \\
\hline Very satisfactory & 21 & --- & $--\infty$ & 19.0 & 61.9 & 14.3 \\
\hline Relatively satisfactory & 45 & 4.4 & 8.9 & 20.0 & 51.1 & 13.3 \\
\hline Relatively unsatisfactory & 9 & 55.6 & 11.1 & 11.1 & 22.2 & --- \\
\hline Very unsatisfactory & 1 & --- & 100.0 & $-\cdots$ & --- & $-\cdots$ \\
\hline No answer & 5 & $-\cdots-$ & 20.0 & 20.0 & 60.0 & --- \\
\hline TOTAL & 81 & & & & & \\
\hline MEAN PERCENTAGE & & 8.6 & 8.6 & 18.5 & 50.6 & 11.1 \\
\hline
\end{tabular}




\section{TABLE 64}

CORRELATION BETWEEN NON-ADVENTIST SPOUSE'S ATTITUDE TOWARD THE CHURCH AND DEGREE OF QUARRELING BETWEEN MARRIAGE

PARTNERS OF DIVIDED FAMILIES

\begin{tabular}{|c|c|c|c|c|c|c|}
\hline \multirow{2}{*}{$\begin{array}{l}\text { Degree of Quarreling } \\
\text { Between Marriage } \\
\text { Partners of Divided } \\
\text { Homes }\end{array}$} & \multirow{2}{*}{$\begin{array}{c}\text { Total } \\
\text { Responses }\end{array}$} & \multicolumn{5}{|c|}{ Percentage of Total } \\
\hline & & $\begin{array}{r}\text { Strong1y } \\
\text { Opposed }\end{array}$ & $\begin{array}{r}\text { Somewhat } \\
\text { opposed }\end{array}$ & $\begin{array}{l}\text { No Interest in } \\
\text { Christianity } \\
\text { but not opposed }\end{array}$ & $\begin{array}{l}\text { Somewhat } \\
\text { Interested }\end{array}$ & $\begin{array}{l}\text { Strongly } \\
\text { Interested }\end{array}$ \\
\hline Often quarrel heatedly & 3 & --- & 66.7 & 33.3 & --- & --- \\
\hline $\begin{array}{l}\text { Often quarrel but not } \\
\text { heatedly }\end{array}$ & 34 & 5.9 & 2.9 & 17.6 & 55.9 & 17.6 \\
\hline $\begin{array}{l}\text { Seldom quarrel, little } \\
\text { in common }\end{array}$ & 24 & 4.2 & 12.5 & 25.0 & 50.0 & 4.2 \\
\hline $\begin{array}{l}\text { Seldom quarrel, but } \\
\text { often silently } \\
\text { antagonistic }\end{array}$ & 2 & 100.0 & $-\infty--$ & --- & $-\cdots$ & ---- \\
\hline Never quarrel & 14 & 7.1 & 7.1 & 14.3 & 50.0 & 14.3 \\
\hline No answer & 2 & 25.0 & $-\cdots$ & --- & 75.0 & ---- \\
\hline TOTAL & 81 & & & & & \\
\hline MEAN PERCENTAGE & & 8.6 & 8.6 & 18.5 & 50.6 & 11.1 \\
\hline
\end{tabular}


in the church. On the other hand, there was a decided drop in the percentage of those whose non-member spouses showed an interest in the church among those who reported they were not very satisfied, who were dissatisfied, or who considered their sexual relationships as a source of real friction.

The degree of mutual understanding and level of communication in divided families also appears to be related (see Eable 66). When the degree of mutual understanding was seen as "poor," all of the non-member spouses were reported as strongly opposed. But when it was judged "fair," the percentage who opposed the church dropped to 11.1 percent; when it was rated "good," 2.3 percent opposed strongly; and when the understanding level was "excellent," none of the non-member spouses strongly opposed their member spouses and the church.

It is true that the population surveyed was not large and thus the statistics may not be an exact reflection of the attitudes in all divided families. There may also be a question raised as to whether the relationship of the marriage partner in these divided homes affected the attitude toward the church of the non-member spouse or was affected by it. It can be said, however, that certain trends can be noted, and that there is an apparent relationship between the two. It would further seem that improving the relationship between the husband and the wife in these divided homes might be one of the best ways to develop the proper atmosphere for reaching the non-member spouses with the gospel message and uniting the families in the church. 
TABLE 65

CORRELATION BETWEEN NON-ADVENTIST SPOUSE'S ATTITUDE TOWARD THE CHURCH AND DEGREE OF: SEXUAL SATISFACTION IN

DIVIDED FAMILIES

\begin{tabular}{|c|c|c|c|c|c|c|}
\hline \multirow{2}{*}{$\begin{array}{l}\text { Degree of Sexual } \\
\text { Satisfaction Be- } \\
\text { tween Spouses of } \\
\text { Divided Homes }\end{array}$} & \multirow{2}{*}{$\begin{array}{c}\text { Total } \\
\text { Responses }\end{array}$} & \multicolumn{5}{|c|}{ Percentage of Total } \\
\hline & & $\begin{array}{r}\text { Strong1y } \\
\text { Opposed }\end{array}$ & $\begin{array}{l}\text { Somewhat } \\
\text { Opposed }\end{array}$ & $\begin{array}{l}\text { No Interest in } \\
\text { Christianity } \\
\text { but not opposed }\end{array}$ & $\begin{array}{l}\text { Somewhat } \\
\text { Interested }\end{array}$ & $\begin{array}{c}\text { Strongly } \\
\text { Interested }\end{array}$ \\
\hline Very satisfied & 53 & 9.4 & 5.7 & 15.1 & 50.9 & 15.1 \\
\hline Not too satisfied & 8 & 12.5 & 12.5 & 50.0 & 25.0 & $-\ldots$ \\
\hline Dissatisfied & 4 & $-\infty$ & 25.0 & 25.0 & 25.0 & 25.0 \\
\hline $\begin{array}{l}\text { A cause of major } \\
\text { problems }\end{array}$ & 2 & 50.0 & 50.0 & $-\cdots$ & $---\infty$ & --- \\
\hline No answer & 14 & ---- & 7.1 & 14.3 & 78.6 & --- \\
\hline TOTAL & 81 & & & & & \\
\hline MEAN PERCENTAGE & & 8.6 & 8.6 & 18.5 & 50.6 & 11.1 \\
\hline
\end{tabular}


TABLE 66

CORRELATION BETWEEN NON-ADVENTIST SPOUSE'S ATTITUDE TOWARD THE CHURCH AND MUTUAL UNDERSTANDING AND LEVEL OF COMMUNICATION IN DIVIDED FAMILIES

\begin{tabular}{|c|c|c|c|c|c|c|}
\hline \multirow{2}{*}{$\begin{array}{l}\text { Degree of Mutual } \\
\text { Understanding } \\
\text { and Level of } \\
\text { Communication in } \\
\text { Divided Homes }\end{array}$} & \multirow{2}{*}{$\begin{array}{c}\text { Total } \\
\text { Responses }\end{array}$} & \multicolumn{5}{|c|}{ Percentage of Total } \\
\hline & & $\begin{array}{r}\text { Strong1y } \\
\text { Opposed }\end{array}$ & $\begin{array}{r}\text { Somewhat } \\
\text { Opposed }\end{array}$ & $\begin{array}{l}\text { No Interest in } \\
\text { Christianity } \\
\text { but not opposed }\end{array}$ & $\begin{array}{c}\text { Somewhat } \\
\text { Interested }\end{array}$ & $\begin{array}{c}\text { Strongly } \\
\text { Interested }\end{array}$ \\
\hline Poor & 3 & 100.0 & ---- & $-\dot{-}$ & ---- & --- \\
\hline Fair & 27 & 11.1 & 14.8 & 25.9 & 33.3 & 7.4 \\
\hline Good & 43 & 2.3 & 2.3 & 18.6 & 67.8 & 14.0 \\
\hline Excellent & 2 & ---- & 50.0 & --- & 50.0 & $-\cdots$ \\
\hline No answer & 6 & ---- & 16.7 & $-\cdots$ & 66.7 & 16.7 \\
\hline TOTAL & 81 & & & & & \\
\hline MEAN PERCENTAGE & & 8.6 & 8.6 & 18.5 & 50.6 & 11.1 \\
\hline
\end{tabular}




\section{CHAPTER VIII}

\section{STABILITY AND HAPPINESS OF THE FAMILY}

The Japanese family is a unique product of Japanese society and culture. And the changes in Japanese society and culture that have occured with dramatic insistence since Comodore Matthew Perry's "black ships" sailed into Uraga Bay in 1853 have not been without their affect on the family.

Thinking people in Japan have noted with growing concern the changes that have been taking place in the family. From a clancentered, male-dominated, hierarchical stabilizer and molder of society, the family has moved rapidly toward a Western-oriented nuclear family, with all of its strengths and weaknesses. The rapid rise in recent years of divorce rates and of juvenile delinquency statistics has appalled and dismayed parents and sociologists alike, who somehow felt that these were symptoms of Western society and would not affect their society. That Japanese society and the Japanese family have been affected is quite evident.

To what extent have these changes and stresses affected the Japanese Adventist family? How stable is it? What factors can be noted as contributing factors to the stability and happiness of the family? These are some of the areas the Happiness and Stability of Marriage section of the Adventist Family Survey sought to uncover and which will be discussed in this chapter. 
There was evidence of hesitancy on the part of some respondents in answering certain questions in this section of the survey dealing with personal matters. Refraining from responding or answering with less than complete candor naturally affects the accuracy of the results. However, in spite of these limitations, apparent trends can be noted which should not be ignored but should be interpreted with caution.

\section{Marriage Partners' Evaluation of Success and Happiness of their Own Marriage}

The question was asked, "How would you classify the success and happiness of your marriage?" Table 67 gives the responses of united family. spouses and compares them to the responses received from divided families. Tables 68 through 80 analyze responses according to such variables as sex and age of marriage partners, length of marriage, age differential of marriage partners, method of choosing a partner, the degree of acquaintance before marriage, the employment category of the major wage earner, the yearly family income, the level of education and Adventist background, the regularity of family worship and extent of praying together, and the time of becoming a church member in relation to the time of entering into marriage.

According to table 67 , it can be seen that Adventist spouses on the whole were quite well satisfied with the happiness of their marriages. Noticeable, however, is the striking difference in perceived happiness between the spouses of united and divided families. Not only was the percentage of divided family spouses who judged 
their marriage as very satisfactory lower by 16.0 percent than that of united families, but those who felt their marriage was unsatisfactory was 7.7 percent higher.

\section{TABLE 67}

PERSONAL EVALUATION OF SUCCESS AND HAPPINESS OF OWN MARRIAGE

\begin{tabular}{|c|c|c|c|c|}
\hline & \multicolumn{2}{|c|}{ United Families } & \multicolumn{2}{|c|}{ Divided Families } \\
\hline & $\begin{array}{c}\text { Total } \\
\text { Responses }\end{array}$ & $\begin{array}{c}\text { Percentage } \\
\text { of Total }\end{array}$ & $\begin{array}{c}\text { Total } \\
\text { Responses }\end{array}$ & $\begin{array}{c}\text { Percentage } \\
\text { of Total }\end{array}$ \\
\hline Very satisfactory & 484 & 41.9 & 21 & 25.9 \\
\hline $\begin{array}{l}\text { Relatively satis- } \\
\text { factory }\end{array}$ & 582 & 50.4 & 45 & 55.6 \\
\hline $\begin{array}{l}\text { Relatively unsatis- } \\
\text { factory }\end{array}$ & 52 & 4.5 & 9 & 11.1 \\
\hline Very unsatisfactory & 1 & .1 & 1 & 1.2 \\
\hline No answer & 36 & 3.1 & 5 & 6.2 \\
\hline TOTAL & 1155 & 100.0 & 81 & 100.0 \\
\hline
\end{tabular}

Table 68 indicates that husbands were slightly more inclined to feel that everything was fine with their marriage than were their wives. When the evaluation of their marriage was studied according to the age of the marriage partner, as noted in table 69 , and by the length of their marriage, as recorded in table 70 , it is seen that a larger percentage of those twenty-four years of age or under and those who had been married less than two years considered their marriages to be very satisfactory. 
TABLE 68

CORRELATION BETWEEN EVALUATION OF SUCCESS AND HAPPINESS OF MARRIAGE AND SEX OF MARRIAGE PARTNER

\begin{tabular}{|c|c|c|c|c|c|}
\hline & \multirow{2}{*}{$\begin{array}{l}\text { Number of } \\
\text { Responses }\end{array}$} & \multicolumn{4}{|c|}{ Percentage of Responses } \\
\hline & & $\begin{array}{c}\text { Very } \\
\text { Satisfactory }\end{array}$ & $\begin{array}{l}\text { Relatively } \\
\text { Satisfactory }\end{array}$ & $\begin{array}{l}\text { Relatively Un- } \\
\text { satisfactory }\end{array}$ & $\begin{array}{c}\text { Very Unsatis- } \\
\text { factory }\end{array}$ \\
\hline Husb and & 578 & 44.1 & 48.3 & 4.0 & --- \\
\hline Wife & 574 & 39.4 & 52.8 & 5.1 & .2 \\
\hline No answer & 3 & 100.0 & --- & -- & $\therefore-$ \\
\hline TOTAL & 1155 & & & & \\
\hline MEAN PERCENTAGE & & 41.9 & 50.4 & 4.5 & .1 \\
\hline
\end{tabular}


TABLE 69

CORRELATION BETWEEN PERSONAL EVALUATION OF SUCCESS AND HAPPINESS OF MARRIAGE AND AGE OF MARRIAGE PARTNERS

\begin{tabular}{|c|c|c|c|c|c|}
\hline \multirow{2}{*}{$\begin{array}{c}\text { Categories } \\
\text { of Age }\end{array}$} & \multirow{2}{*}{$\begin{array}{l}\text { Number of } \\
\text { Responses }\end{array}$} & \multicolumn{4}{|c|}{ Percentage of Responses } \\
\hline & & $\begin{array}{c}\text { Very } \\
\text { Satisfactory }\end{array}$ & $\begin{array}{c}\text { Relatively } \\
\text { Satisfactory }\end{array}$ & $\begin{array}{l}\text { Relatively Un- } \\
\text { satisfactory }\end{array}$ & $\begin{array}{c}\text { Very Unsatis- } \\
\text { factory }\end{array}$ \\
\hline Under 24 & 18 & 55.6 & 33.3 & 11.1 & --- \\
\hline $25-29$ & 102 & 43.1 & 53.9 & 2.9 & --- \\
\hline $30-34$ & 181 & 39.8 & 53.0 & 5.5 & --- \\
\hline $35-39$ & 172 & 36.6 & 55.8 & 5.2 & .6 \\
\hline $40-49$ & 305 & 43.0 & 49.5 & 4.9 & --- \\
\hline $50-59$ & 186 & 44.6 & 46.2 & 4.3 & $-\cdots$ \\
\hline 60 and over & 191 & 42.4 & 48.2 & 2.6 & $-\cdots$ \\
\hline TOTAL & 1155 & & . & & \\
\hline MEAN PERCENT & & 41.9 & 58.2 & 5.2 & .1 \\
\hline
\end{tabular}


TABLE 70

CORRELATION BETWEEN EVALUATION OF SUCCESS

AND HAPPINESS OF MARRIAGE AND LENGTH

OF MARRIAGES

\begin{tabular}{|c|c|c|c|c|c|c|c|c|c|c|}
\hline \multirow[b]{2}{*}{$\begin{array}{l}\text { Length of } \\
\text { Marriages }\end{array}$} & \multicolumn{5}{|c|}{ United Families } & \multicolumn{5}{|c|}{ Divided Families } \\
\hline & 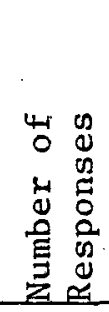 & 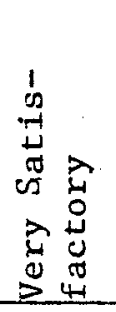 & 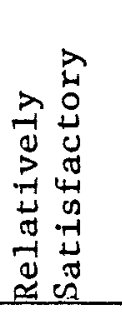 & 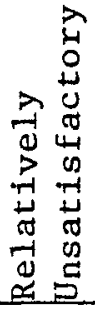 & 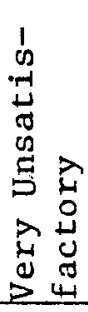 & 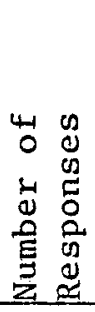 & 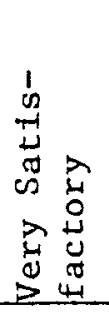 & 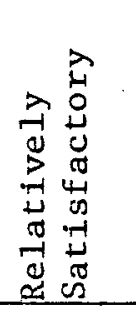 & 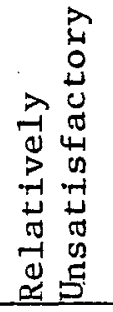 & 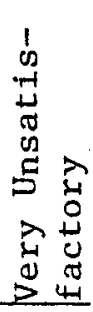 \\
\hline ess than & & & & & & & & & & \\
\hline 2 years & 70 & 52.9 & 42.9 & 4.3 & -- & 1 & --- & 100.0 & $--\infty$ & --- \\
\hline $2-5$ years & 129 & 28.7 & 61.2 & 9.3 & -- & 5 & 20.0 & 80.0 & --- & -- \\
\hline $6-9$ years & 180 & 43.3 & 52.8 & 1.7 & -- & 4 & 25.0 & 50.0 & 25.0 & -- \\
\hline $10-14$ years & 189 & 40.7 & 49.2 & 7.4 & .5 & 7 & 28.6 & 28.6 & 42.9 & -- \\
\hline $15-24$ years & 265 & 42.3 & 50.2 & 3.4 & -- & 24 & 29.2 & 58.2 & 8.3 & -- \\
\hline $25-34$ years & 163 & 40.5 & 52.8 & 4.9 & -- & 27 & 25.9 & 59.3 & 7.4 & -- \\
\hline $\begin{array}{l}35 \text { years or } \\
\text { more }\end{array}$ & 159 & 48.4 & 41.5 & 1.9 & -- & 13 & 23.1 & 46.2 & 7.7 & 7.7 \\
\hline TOTAL & 1155 & & & & & 81 & & & & \\
\hline MEAN PERCENTAGE & & 41.9 & 50.4 & 4.5 & .1 & & 25.9 & 55.6 & 11.1 & 1.2 \\
\hline
\end{tabular}

It should come as no surprise that the largest percentage of marriage partners who reported their marriage as very satisfactory came from among those who had been married two years or less. It is perhaps significant that the smallest percentage so reporting had been married between two and five years. This is no doubt related to the end of the honeymoon period of their marriage, to mounting financial problems, to marriage adjustments, and to the addition of 
children to the family, all of which added pressures and tensions to the marriage. Interestingly, next to the first two years of marriage, the period of married life after 35 years of living together was reported by united family spouses to be the most satisfactory period of their married life.

The divided family spouses in every period of their marriage, consistently reported a greater degree of dissatisfaction with their marriages. This is particularly noticeable during the six-to-fourteen year period of time after their marriage began. The comparatively small number of respondents in some of the categories no doubt makes these statistics somewhat less than perfect as barometers of the feelings of divided family spouses in general in regard to their marriage happiness.

Table 71 indicates the relationship of the age differential of the husband and wife to the question of happiness. The total percentage of husbands who were older than their wives was only slightly larger than that of wives who were older than their husbands. It would be interesting to know if this seeming disregard to which marriage partner was the older was typical of Japanese society as a whole. A comparison of these statistics to those of Adventist families in Western society would also be significant.

A look at table 71 indicates that, for whatever reasons there might be, when the wife was older than her husband the percentage of those who reported their marriage as very satisfactory increased in every instance. Before drawing conclusions from this fact, however, it might be well to note that the percentage of those 
TABLE 71

CORRELATION BETWEEN EVALUATION OF SUCCESS AND

HAPPINESS OF MARRIAGE AND AGE DIFFERENTIALS

OF MARRIAGE PARTNERS

\begin{tabular}{|c|c|c|c|c|c|c|}
\hline \multirow[b]{2}{*}{$\begin{array}{l}\text { Age Differential of } \\
\text { Marriage Partners }\end{array}$} & \multicolumn{2}{|c|}{$\begin{array}{c}\text { Total } \\
\text { Responses }\end{array}$} & \multicolumn{4}{|c|}{ Percentage of Total } \\
\hline & $\begin{array}{l}\mathscr{0} \\
\stackrel{0}{E} \\
\text { E }\end{array}$ & 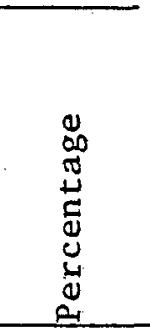 & 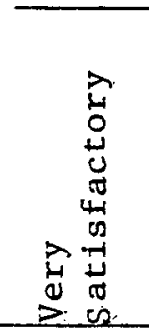 & 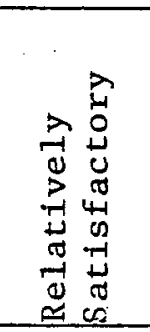 & 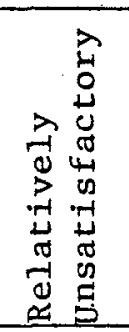 & 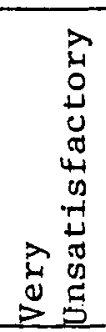 \\
\hline Husband $1-2$ years older & 187 & 16.2 & 37.4 & 54.5 & 5.3 & -- \\
\hline Husband $3-5$ years older & 195 & 16.9 & 40.5 & 52.8 & 2.1 & .5 \\
\hline Husband $6-10$ years older & 133 & 11.5 & 43.6 & 49.6 & 4.5 & -- \\
\hline $\begin{array}{l}\text { Husband more than } 10 \\
\text { years older }\end{array}$ & 24 & 2.1 & 29.2 & 54.2 & 4.2 & -- \\
\hline (Husband older--totals) & $(539)$ & $(46.7)$ & $(39.7)$ & $(52.7)$ & $(3.9)$ & $(.2)$ \\
\hline Wife $1-2$ years older & 166 & 14.4 & 41.0 & 48.8 & 7.8 & - \\
\hline Wife $3-5$ years older & 190 & 16.5 & 42.6 & 48.4 & 4.7 & -- \\
\hline Wife $6-10$ years older & 125 & 10.8 & 48.0 & 45.6 & 4.0 & -- \\
\hline $\begin{array}{l}\text { Wife more than } 10 \\
\text { years older }\end{array}$ & 20 & 1.7 & 40.0 & 60.0 & --- & -- \\
\hline (Wife older--totals) & $(501)$ & $(43.4)$ & $(43.3)$ & $(48.3)$ & $(5.4)$ & $(--)$ \\
\hline $\begin{array}{l}\text { Husband and wife the } \\
\text { same age }\end{array}$ & 113 & 9.8 & 45.1 & 49.6 & 3.5 & -- \\
\hline No answer & 2 & .2 & 100.0 & $-\infty-$ & --- & -- \\
\hline TOTAL & 1155 & 100.0 & & & & \\
\hline MEAN PERCENTAGE & & & 41.9 & 50.4 & 4.5 & .1 \\
\hline
\end{tabular}


who judged their marriage as unsatisfactory also came from families in which the wife was older. Until further evidence is available, perhaps it should be said that the happiness levels of the marriages are not dependent to any degree on which partner is the older.

By far the greatest percentage of happy and satisfied Adventist marriages was seen in those families who had made their own choice as to marriage partners. Table 72 evaluates the marriage happiness of these couples as compared to those in which the marriage was arranged by the parents or by a nakōdo, or marriage broker. A total of nearly 43.0 percent of those who had made their own choice as to marriage partners reported their marriages as very successful as compared to 37.2 percent when their parents had made that decision.

A decided contribution to the happiness of the Adventist family can be noted in table 73 which relates happiness in marriage to the degree of acquaintance the couple had with one another before their marriage. From a low of 31.3 percent for those with no acquaintance whatever to a high of 65.0 percent for those who were very well acquainted, the percentage of those reporting happy, successful marriages increased in proportion to the degree of their acquaintance before marriage. Conversely, a larger percentage of those who had little or no acquaintance before marriage reported their marriage as unsatisfactory.

Table 74 describes the happiness of the marriage according to the employment category of the major wage eamer. The largest percentage of those reporting a very satisfactory marriage came from professional or managerial categories, and the lowest percentage came from among Adventist literature evangelists. 
TABLE 72

CORRELATION BETWEEN EVALUATION OF SUCCESS AND HAPPINESS

OF MARRIAGE AND METHOD OF CHOOSING

MARRIAGE PARTNERS

\begin{tabular}{|c|c|c|c|c|c|}
\hline \multirow{2}{*}{$\begin{array}{l}\text { Method of Choosing } \\
\text { Marriage Partners }\end{array}$} & \multirow{2}{*}{$\begin{array}{l}\text { Number of } \\
\text { Respònses }\end{array}$} & \multicolumn{4}{|c|}{ Percentage of Total } \\
\hline & & $\begin{array}{c}\text { Very } \\
\text { Satisfactory }\end{array}$ & $\begin{array}{l}\text { Relatively } \\
\text { Satisfactory }\end{array}$ & $\begin{array}{l}\text { Relatively Un- } \\
\text { satisfactory }\end{array}$ & $\begin{array}{l}\text { Very Un- } \\
\text { satisfactory }\end{array}$ \\
\hline $\begin{array}{l}\text { Marriage partner chosen } \\
\text { by parents }\end{array}$ & 94 & 37.2 & 47.9 & 6.4 & -- \\
\hline $\begin{array}{l}\text { Marriage partner chosen } \\
\text { by selves }\end{array}$ & 940 & 42.9 & 50.4 & 4.5 & -- \\
\hline Other methods & 99 & 38.4 & 49.5 & 4.0 & 1.0 \\
\hline No answer & 22 & 36.4 & 63.6 & -- & -- \\
\hline TOTAL & 1155 & & & & \\
\hline MEAN PERCENTAGE & & 41.9 & 50.4 & 4.5 & .1 \\
\hline
\end{tabular}


TABLE 73

CORRELATION BETWEEN EVALUATION OF SUCCESS AND HAPPINESS

OF MARRIAGE AND DEGREE OF ACQUAINTANCE BEFORE MARRIAGE

\begin{tabular}{|c|c|c|c|c|c|}
\hline \multirow{2}{*}{$\begin{array}{c}\text { Degree of Acquaintance } \\
\text { of Marriage Partners } \\
\text { Before Marriage }\end{array}$} & \multirow{2}{*}{$\begin{array}{l}\text { Number of } \\
\text { Responses }\end{array}$} & \multicolumn{4}{|c|}{ Percentage of Total } \\
\hline & & $\begin{array}{c}\text { Very } \\
\text { Satisfactory }\end{array}$ & $\begin{array}{c}\text { Relatively } \\
\text { Satisfactory }\end{array}$ & $\begin{array}{l}\text { Relatively Un- } \\
\text { satisfactory }\end{array}$ & $\begin{array}{c}\text { Very Un- } \\
\text { satisfactory }\end{array}$ \\
\hline Not acquainted at all & 262 & 31.3 & 56.5 & 6.1 & .4 \\
\hline Only slightly acquainted & 416 & 35.3 & 54.3 & 7.5 & -- \\
\hline Rather we11 acquainted & 239 & 45.6 & 53.1 & .4 & -- \\
\hline Very we 11 acquainted & 217 & 65.0 & 30.4 & 1.8 & -- \\
\hline No answer & 21 & 23.8 & 71.4 & -- & -- \\
\hline TOTAL & 1155 & & & & \\
\hline MEAN PERCENTAGE & & 41.9 & 50.4 & 4.5 & .1 \\
\hline
\end{tabular}


TABLE 74

CORRELATION BETWEEN EVALUATION OF SUCCESS AND HAPPINESS

OF MARRIAGE AND EMPLOYMENT CATEGORIES OF MARRIAGE PARTNERS

\begin{tabular}{|c|c|c|c|c|c|}
\hline \multirow{2}{*}{ Employment Categories } & \multirow{2}{*}{$\begin{array}{l}\text { Number of } \\
\text { Responses }\end{array}$} & \multicolumn{4}{|c|}{ Percentage of Total } \\
\hline & & $\begin{array}{c}\text { Very } \\
\text { Satisfactory }\end{array}$ & $\begin{array}{c}\text { Relatively } \\
\text { Satisfactory }\end{array}$ & $\begin{array}{l}\text { Relatively } U_{n-} \\
\text { satisfactpru }\end{array}$ & $\begin{array}{c}\text { Very Un- } \\
\text { satisfactory }\end{array}$ \\
\hline Adventist church employee & 346 & 47.1 & 47.7 & 2.9 & -- \\
\hline Adventist literature evangelist & 74 & 32.4 & 60.8 & 5.4 & -- \\
\hline $\begin{array}{l}\text { Self-employed (not including } \\
\text { literature evangelist) }\end{array}$ & 276 & 36.2 & 53.6 & 5.8 & -- \\
\hline Salaried--largely skilled & 164 & 40.2 & 50.0 & 6.7 & .6 \\
\hline Salaried--largely manual & 130 & 37.7 & 55.4 & 4.6 & $-\dot{-}$ \\
\hline Professional or managerial & 141 & 53.2 & 39.7 & 2.8 & -- \\
\hline other & 10 & 10.0 & 90.0 & --- & -- \\
\hline No answer & 14 & 42.9 & 35.7 & 7.1 & -- \\
\hline TOTAL & 1155 & & & & \\
\hline MEAN PERCENTAGE & & 41.9 & 50.4 & 4.5 & .1 \\
\hline
\end{tabular}


By comparing table 75 with table 74 it may be noted that the income level of the family may possibly have had more to do with their happiness than their type of employment. The highest percentage of those who reported satisfaction with their marriage earned over $¥ 5,000,000$ yearly, while the lowest percentage had a yearly family income of less than $¥ 1,000,000$. In harmony with these findings statistics indicate that of those who were relatively dissatisfied with their marriage, 5.8 percent came from the lowest income bracket and none came from the upper income bracket. In a similar manner, table 76 , which relates perceived happiness to the education level of the marriage partner, indicates that those with the lowest levels of education consistently expressed themselves as being less happy than those with higher levels of education. Perhaps, as tables 75 and 76 signify, the income and education levels do have a decided bearing on the happiness of the homes of Adventist couples, and a certain dissatisfaction is noted in families when the income or education level falls below that of the mean levels of the society of which they are a part. Whether these statistics would be different if the income spread were expanded to include the wealthy is something which could be the subject of further study.

Tables 77 through 80 evaluate the happiness of the family by certain religious variables. Table 77 which judges the happiness of the family by comparing it to the Adventist background of the marriage partners is somewhat inconclusive. Although thirdgeneration Adventists reported a higher level of happiness than did 
TABLE 75

CORRELATION BETWEEN EVALUATION OF SUCCESS AND HAPPINESS OF MARRIAGE AND YEARLY FAMILY INCOME

\begin{tabular}{|c|c|c|c|c|c|}
\hline \multirow{2}{*}{ Yearly Family Income } & \multirow{2}{*}{$\begin{array}{l}\text { Number of } \\
\text { Responses }\end{array}$} & \multicolumn{4}{|c|}{ Percentage of Total } \\
\hline & & $\begin{array}{c}\text { Very } \\
\text { Satisfactory }\end{array}$ & $\begin{array}{c}\text { Relatively } \\
\text { Satisfactory }\end{array}$ & $\begin{array}{l}\text { Relatively Un- } \\
\text { satisfactory }\end{array}$ & $\begin{array}{l}\text { Very Un- } \\
\text { satisfactory }\end{array}$ \\
\hline Less than one million yen & 172 & 31.4 & 59.9 & 5.8 & -- \\
\hline One to three million yen & 770 & 41.4 & 51.3 & 4.3 & .1 \\
\hline Three to five million yen & 148 & 51.4 & 40.5 & 4.1 & -- \\
\hline Over five million yen & 43 & 58.1 & 37.2 & -- & -- \\
\hline No answer & 22 & 45.5 & 36.4 & 13.6 & -- \\
\hline TOTAL & 1155 & & & & \\
\hline MEAN PERCENTAGE & & 41.9 & 50.4 & 4.5 & .1 \\
\hline
\end{tabular}


TABLE 76

CORRELATION BETWEEN EVALUATION OF SUCCESS AND HAPPINESS

OF MARRIAGE AND LEVEL OF EDUCATION OF

MARR IAGE PARTNERS

\begin{tabular}{|c|c|c|c|c|c|}
\hline \multirow{2}{*}{ Level of Education } & \multirow{2}{*}{$\begin{array}{l}\text { Number of } \\
\text { Responses }\end{array}$} & \multicolumn{4}{|c|}{ Percentage of Total. } \\
\hline & & $\begin{array}{c}\text { Very } \\
\text { Satisfactory }\end{array}$ & $\begin{array}{l}\text { Relatively } \\
\text { Satisfactory }\end{array}$ & $\begin{array}{l}\text { Relatively Ün- } \\
\text { satisfactory }\end{array}$ & $\begin{array}{c}\text { Very Un- } \\
\text { satisfactory }\end{array}$ \\
\hline Junior high school & 306 & 35.0 & 54.9 & 3.9 & -- \\
\hline Senior high school & 407 & 38.8 & 53.6 & 5.7 & -- \\
\hline Junior college & 224 & 43.3 & 49.6 & 4.5 & .4 \\
\hline Senior college & 183 & 56.8 & 37.2 & 3.8 & -- \\
\hline Graduate school & 28 & 60.7 & 39.3 & -- & -- \\
\hline No answer & 7 & 14.3 & 85.7 & -- & -- \\
\hline TOTAL : & 1155 & & & & \\
\hline MEAN PERCENTAGE & & 41.9 & 50.4 & 4.5 & .1 \\
\hline
\end{tabular}


TABLE 77

CORRELATION BETWEEN EVALUATION OF SUCCESS AND HAPPINESS

OF MARRIAGE AND ADVENTIST BACKGROUND OF MARRIAGE PARTNERS

\begin{tabular}{|c|c|c|c|c|c|}
\hline \multirow{2}{*}{$\begin{array}{c}\text { Degree of Adventist } \\
\text { Background }\end{array}$} & \multirow{2}{*}{$\begin{array}{l}\text { Number of } \\
\text { Responses }\end{array}$} & \multicolumn{4}{|c|}{ Percentage of Total } \\
\hline & & $\begin{array}{c}\text { Very } \\
\text { Satisfactory }\end{array}$ & $\begin{array}{c}\text { Relatively } \\
\text { Satisfactory }\end{array}$ & $\begin{array}{l}\text { Relatively Un- } \\
\text { satisfactory }\end{array}$ & $\begin{array}{c}\text { Very Un- } \\
\text { satisfactory }\end{array}$ \\
\hline No Adventist background, & & & & & $\cdots$ \\
\hline first-generation Adventist & 906 & 42.6 & 50.3 & 4.1 & -- \\
\hline Second-generation Adventist & 190 & 36.8 & 53.2 & $6: 8$ & .5 \\
\hline Third- or fourth-generation & & & & & \\
\hline Adventist & 45 & 51.1 & 42.2 & 2.2 & - \\
\hline No answer & 14 & 35.7 & 42.9 & 7.1 & -- \\
\hline TOTAL & 1155 & & & & 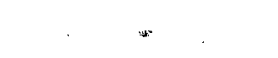 \\
\hline MEAN PERCENTAGE & & 41.9 & 50.4 & 4.5 & .1 \\
\hline
\end{tabular}


others, those with no Adventist background whatever reported somewhat higher levels of satisfaction than did second-generation Adventist couples.

Tables 78 and 79 show a significantly larger percentage of those who had family worship regularly and who prayed together each day reporting their marriage a success. The greatest number of those who reported that their marriage was unhappy came from among those who never had family worship and from those who seldom if ever prayed together.

What relationship, if any, family happiness had to the time the marriage partners were baptized in relationship to their becoming church members is indicated in table 80 . There seems to be very little difference in the perceived happiness levels of those who had married non-Adventist mates as compared to those who had married within the church or had married before they became church members. There is, however, a slightly higher percentage of these couples, who had married non-Adventist mates, who reported their marriage was relatively unhappy as compared to those families in which both the husband and the wife were baptized either before or after their marriage. A greater contrast, on the other hand, can be seen by comparing the percentage of these couples with those in which one of the marriage partners remained a non-member (see table 70). 
TABLE 78

CORRELATION BETWEEN EVALUATION OF SUCCESS AND HAPPINESS

OF MARRIAGE AND REGULARITY OF FAMILY WORSHIP

\begin{tabular}{|c|c|c|c|c|c|}
\hline \multirow{2}{*}{$\begin{array}{c}\text { Degree of Regularity } \\
\text { in Family Worship }\end{array}$} & \multirow{2}{*}{$\begin{array}{l}\text { Number of } \\
\text { Responses }\end{array}$} & \multicolumn{4}{|c|}{ Percentage of Total } \\
\hline & & $\begin{array}{c}\text { Very } \\
\text { Satisfactory }\end{array}$ & $\begin{array}{l}\text { Relatively } \\
\text { Satisfactory }\end{array}$ & $\begin{array}{l}\text { Relatively Un- } \\
\text { satisfactory }\end{array}$ & $\begin{array}{l}\text { Very Un-- } \\
\text { satisfactory }\end{array}$ \\
\hline Never have family worship & 132 & 36.4 & 50.0 & 8.3 & -- \\
\hline Sometimes have family worship & 391 & 36.6 & 54.7 & 5.9 & .3 \\
\hline $\begin{array}{l}\text { Have family worship regularly } \\
\text { in mornings }\end{array}$ & 292 & 41.4 & 52.7 & 3.1 & -- \\
\hline $\begin{array}{l}\text { Have family worship regularly } \\
\text { in evenings }\end{array}$ & 74 & 50.0 & 44.6 & 4.1 & -- \\
\hline $\begin{array}{l}\text { Have family worship regularly } \\
\text { both mornings and evenings }\end{array}$ & 238 & 52.1 & 43.7 & 1.7 & -- \\
\hline No answer & 28 & 39.3 & 39.3 & 7.1 & -- \\
\hline TOTAL & 1155 & & & & \\
\hline MEAN PERCENTAGE & & 41.9 & 50.4 & 4.5 & .1 \\
\hline
\end{tabular}


TABLE 79

CORRELATION BETWEEN EVALUATION OF SUCCESS AND HAPPINESS

OF MARRIAGE AND REGULARITY IN PRAYING TOGETHER

\begin{tabular}{|c|c|c|c|c|c|}
\hline \multirow[b]{2}{*}{ Degree of Regularity } & \multirow{2}{*}{$\begin{array}{l}\text { Number of } \\
\text { Responses }\end{array}$} & \multicolumn{4}{|c|}{ Percentage of Total } \\
\hline & & $\begin{array}{c}\text { Very } \\
\text { Satisfactory }\end{array}$ & $\begin{array}{c}\text { Relatively } \\
\text { Satisfactory }\end{array}$ & $\begin{array}{l}\text { Relatively Un- } \\
\text { satisfactory }\end{array}$ & $\begin{array}{c}\text { Very U:n- } \\
\text { satisfactory }\end{array}$ \\
\hline Never pray together & 154 & 39.0 & 52.2 & 5.2 & .6 \\
\hline $\begin{array}{l}\text { Pray together when prob } \\
\text { arise }\end{array}$ & 109 & 36.7 & 53.2 & 6.4 & -- \\
\hline Daily pray together & 789 & 44.7 & 48.7 & 4.1 & -- \\
\hline No answer & 103 & 30.1 & 56.3 & 4.9 & - \\
\hline TOTAL . & 1155 & & & & \\
\hline MEAN PERCENTAGE & & 41.9 & 50.4 & 4.5 & .1 \\
\hline
\end{tabular}




\section{TABLE 80}

CORRELATION BETWEEN EVALUATION OF SUCCESS AND HAPPINESS

OF MARRIAGE AND TIME OF BECOMING A CHURCH MEMBER IN

RELATION TO TIME OF ENTERING MARRIAGE

\begin{tabular}{|c|c|c|c|c|c|}
\hline \multirow{2}{*}{$\begin{array}{l}\text { Time of Becoming Adventist } \\
\text { Church Member }\end{array}$} & \multirow{2}{*}{$\begin{array}{l}\text { Number of } \\
\text { Responses }\end{array}$} & \multicolumn{4}{|c|}{ Percentage of Total } \\
\hline & & $\begin{array}{c}\text { Very } \\
\text { Satisfactory }\end{array}$ & $\begin{array}{l}\text { Relatively } \\
\text { Satisfactory }\end{array}$ & $\begin{array}{l}\text { Relatively Un- } \\
\text { satisfactory }\end{array}$ & $\begin{array}{l}\text { Very Uin- } \\
\text { satisfactory }\end{array}$ \\
\hline $\begin{array}{l}\text { Both husband and wife } \\
\text { baptized before marriage }\end{array}$ & 823 & 424 & 50.3 & 50 & 1 \\
\hline $\begin{array}{l}\text { Both husband and wife } \\
\text { baptized after marriage }\end{array}$ & 240 & 41.7 & 52.2 & 2.1 & $\therefore$ \\
\hline $\begin{array}{l}\text { Wife baptized before, hus- } \\
\text { band after marriage }\end{array}$ & 41 & 43.9 & 41.5 & 7.3 & $--\infty$ \\
\hline $\begin{array}{l}\text { Husband baptized before, } \\
\text { wife after marriage }\end{array}$ & 39 & 38.5 & 53.8 & 7.7 & -- \\
\hline No answer & 12 & 16.7 & 41.7 & --- & -- \\
\hline TOTAL & 1155 & & & & \\
\hline MEAN PERCENTAGE & & 41.9 & 50.4 & 4.5 & .1 \\
\hline
\end{tabular}




\section{Increase or Decrease of Happiness \\ in the Home}

How do Adventist couples feel about the progression of happiness in their homes? Is it getting better as time goes on or are things going from bad to worse? Table 81 suggests the answers to these questions.

TABLE 81

PROGRESSION OF MARITAI HAPPINESS AS

PERCEIVED BY MARRIAGE PARTNERS

\begin{tabular}{lccccc}
\hline & \multicolumn{2}{c}{ United Families } & & Divided Families \\
& & $\begin{array}{c}\text { Total } \\
\text { Responses }\end{array}$ & $\begin{array}{c}\text { Percentage } \\
\text { of Total }\end{array}$ & $\begin{array}{c}\text { Total } \\
\text { Responses }\end{array}$ & $\begin{array}{c}\text { Percentage } \\
\text { of Total }\end{array}$ \\
\hline $\begin{array}{l}\text { Happiness increasing } \\
\text { Happiness decreasing }\end{array}$ & 779 & 67.4 & & 53 & 65.4 \\
$\begin{array}{l}\text { Happiness level remains } \\
\text { about the same }\end{array}$ & 25 & 2.2 & & 3 & 3.7 \\
$\begin{array}{l}\text { No answer } \\
\text { TOTAL }\end{array}$ & 715 & 24.0 & & 19 & 23.5 \\
\hline
\end{tabular}

Most of the spouses from both united and divided families expressed their opinion that things were getting better, with a slight percentage in favor of the united families. The percentage of those who felt that things were getting worse in their family was very sma11, although not to be ignored. Again, indications are that more couples from divided families than from united families reported the level of happiness in their family to be decreasing as 
time passed. About one out of four of the spouses from both groups indicated the happiness level to be constant in their families.

\section{Potential Problem Areas in Adventist Homes}

Tables 82 and 83 record the responses of Adventist families to the question as to which potential areas of friction had caused the most conflict, if any, in their marriage. There was a comparatively large percentage, 11.5 percent, who gave no answer to this question. This could either indicate that no problems were felt between spouses or that they were reticent to reveal candidly the areas of conflict between themselves and their spouses.

The responses tabulated in table 82 are listed by rank from most to least common areas of conflict as perceived by united family marriage partners. Although the ranking of problem areas was somewhat different for spouses of divided families, when the area of differences as to faith and religion was omitted, both groups showed the same top three problem areas, namely, criticism and nagging, personality differences, and the use of money. It can be clearly seen by the large number of the divided family spouses, most of whom were Adventist wives with non-Adventist husbands, who listed differences in faith and religion as the number one problem in their marriage, that this was a major cause of friction in these families.

Table 83 compares the perceived problem areas in Adventist families with the length of the marriage. The three highest problem areas in each age category have been underlined. for emphasis and clarity. It can be seen from these figures that money seemed to 
TABLE 82

PROBLEM AREAS IN MARRIAGE AS PERCETVED BY ADVENTIST SPOUSES

\begin{tabular}{|c|c|c|c|c|c|c|}
\hline \multirow[b]{2}{*}{$\begin{array}{c}\text { Problem Areas in } \\
\text { Marriage }\end{array}$} & \multicolumn{3}{|c|}{ United Families } & \multicolumn{3}{|c|}{ Divided Families } \\
\hline & $\begin{array}{c}\text { Total } \\
\text { Responses }\end{array}$ & $\begin{array}{c}\text { Percentage } \\
\text { of Tota1 }\end{array}$ & Rank & $\begin{array}{c}\text { Total } \\
\text { Responses }\end{array}$ & $\begin{array}{c}\text { Percentage } \\
\text { of Total }\end{array}$ & Rank \\
\hline Criticism, nagging & 542 & 13.5 & 1 & 47 & 11.1 & 3 \\
\hline Personality differences & 524 & 13.1 & 2 & 63 & 14.8 & 2 \\
\hline Money & 437 & 10.9 & 3 & 44 & 10.4 & 4 \\
\hline Time & 424 & 10.6 & 4 & 25 & 5.9 & 8 \\
\hline Emotions, moods & 408 & 10.2 & 5 & 16 & 3.8 & 10 \\
\hline Communication & 354 & 8.8 & 6 & 21 & 4.9 & 9 \\
\hline Children & 342 & 8.5 & 7 & 35 & 8.2 & 5 \\
\hline Relatives, in-laws & 238 & 5.9 & 8 & 31 & 7.3 & 7 \\
\hline Work, own or spouse's & 212 & 5.3 & 9 & 7 & 1.6 & 12 \\
\hline Sexual relations & 175 & 4.4 & 10 & 34 & 8.0 & 6 \\
\hline Faith and religion & 166 & 4.1 & 11 & 86 & 20.2 & 1 \\
\hline Friends of spouse & 71 & 1.8 & 12 & 7 & 1.6 & 12 \\
\hline Other & 64 & 1.6 & 13 & 2 & .5 & 14 \\
\hline Bad habits of spouse & 55 & 1.4 & 14 & 7 & 1.6 & 12 \\
\hline TOTAL & 4012 & 100.1 & & 425 & 99.9 & \\
\hline
\end{tabular}


TABLE 83

CORRELATION BETWEEN PROBLEM AREAS IN MARRIAGE AS PERCEIVED BY ADVENTIST SPOUSES AND LENGTH OF MARRIAGE

\begin{tabular}{|c|c|c|c|c|c|c|c|c|c|c|c|c|c|}
\hline & \multirow[b]{2}{*}{ 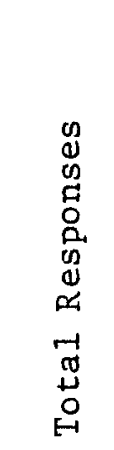 } & \multicolumn{12}{|c|}{ Percentage of Total } \\
\hline & & 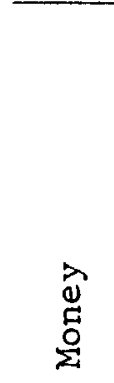 & 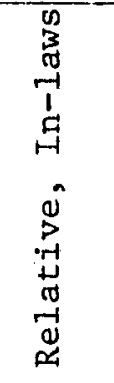 & 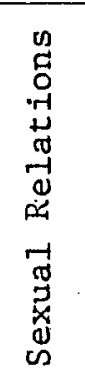 & 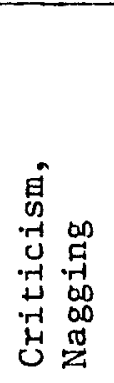 & 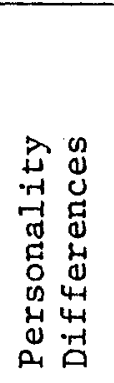 & 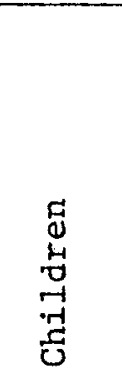 & 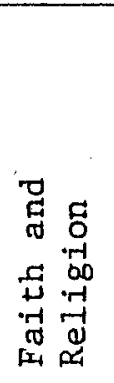 & 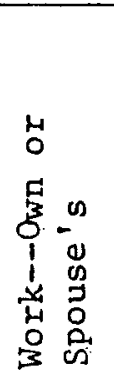 & 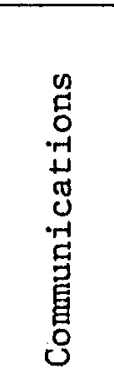 & 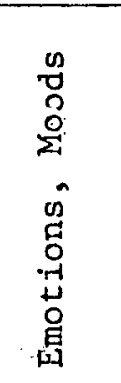 & 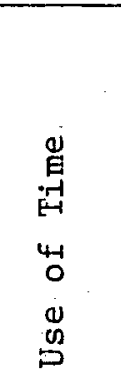 & 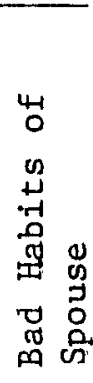 \\
\hline Less than two years & 79 & 5.1 & 3.8 & 2.5 & 21.5 & 12.7 & 1.3 & 3.8 & 5.1 & 5.1 & 19.0 & 11.4 . & 1.3 \\
\hline $2-5$ years & 208 & 9.6 & 7.2 & 6.3 & 13.5 & 11.1 & 6.7 & 4.3 & 6.3 & 6.7 & 12.5 & 13.9 & .5 \\
\hline $6-9$ years & 242 & 9.5 & 12.0 & 3.3 & 13.6 & 14.1 & 7.4 & 2.5 & 4.6 & 8.3 & 9.9 & 11.6 & .4 \\
\hline $10-14$ years & 236 & 8.1 & 5.5 & 5.9 & 12.3 & 13.1 & 14.8 & 3.0 & 3.8 & 5.9 & 7.2 & 12.3 & 2.1 \\
\hline $15-24$ years & 278 & 11.5 & 6.8 & 1.4 & 14.0 & 15.5 & 9.0 & 2.9 & 4.7 & 10.8 & 6.8 & 12.6 & .7 \\
\hline $25-34$ years & 191 & 12.0 & 7.3 & 2.6 & 10.0 & 16.2 & 12.0 & 3.7 & 2.6 & 8.9 & 9.4 & 9.4 & 1.1 \\
\hline 35 years or more & 111 & 15.3 & 7.2 & 1.8 & 8.1 & $\underline{18.9}$ & 8.1 & 4.5 & 2.7 & 9.0 & 9.9 & 7.2 & 2.7 \\
\hline TOTAL & 1345 & & & & & & & & & & & & \\
\hline MEAN PERCENTAGE & & 7.4 & 5.5 & 2.6 & 9.4 & 10.4 & 6.7 & 2.4 & 3.1 & 5.9 & 7.0 & 8.4 & .8 \\
\hline
\end{tabular}

Note: The three highest problem areas in each age category have been underlined for emphasis. 
be more of a problem as time went on, with the lowest percentage, 5.1 percent, reporting money to be a problem in the earliest period of marriage and the highest percentage, 15.3 percent, reporting it a problem in the period of marriage that continued thirty-five years or more.

Problems concerning relatives and in-laws were greatest in the period between six and nine years, and sexual related problems between two and fourteen years. The top problem area, criticism and nagging, was highest in the early years, and although it remained at a rather high level throughout marriage, it decreased somewhat in the later years. Personality differences also remained at a rather high level in every age period with a tendency to become more pronounced the longer the marriage continued. Moodiness seemed to be more of a problem with younger couples.

Summarizing the problem areas in Adventist marriages, the early years of marriage found major areas of conflict in (1) criticism and nagging, (2) emotional problems and moodiness, and (3) the use of time. During the middle period of marriage couples found (1) relatives, (2) criticism, (3) children, (4) communication, (5) the use of time, and (6) sex to be major problem areas. In the later years of marriage, particular problem areas were (1) money, (2) personality differences, and (3) moodiness. An understanding of the problems that face different ages of spouses should be of help to those working to strengthen the Adventist family. 


\section{Divorce as Viewed by Adventist Spouses}

Viewed from the perspective of the alarmingly high and still rising divorce rates in the United States, the Japanese government's statistics showing eleven divorces for every one hundred marriages in $1975^{1}$ seem rather modest. But when these figures are considered from the background of Eastern culture in general and of the traditional Japanese family in particular, they are a cause not only of deep concern but also of alarm.

As has already been noticed in table 8 , the statistics show that a rather small percentage of Adventist spouses have been divorced and remarried. In tables 84 and 85 the attitudes Adventist husbands and wives had toward divorce as a possible solution to marriage conflicts can be seen. Although 64.2 percent of united family spouses have never considered divorce, more than 20 percent have considered it. As table 85 points out, a larger percentage of the wives than the husbands had thought of divorce. These figures seem to indicate some really rough times in adjustment between husbands and wives in Adventist families. It also indicates that the problems affected the wives much more deeply than they did the husbands. The rather large percentage of respondents who gave no answer to this question could also be significant. One is tempted to guess that the majority of those who gave no response would probably not be among those with no marriage problems or those who had never thought of divorce.

\footnotetext{
IJapan Statistical Yearbook, p. 19.
} 
TABLE 84

CONTEMPLATION OF DIVORCE AS SOLUTION TO MARRIAGE PROBLEMS

\begin{tabular}{|c|c|c|c|c|}
\hline \multirow{2}{*}{$\begin{array}{l}\text { Degree of Contemplation } \\
\text { of Divorce as a Solution } \\
\text { to Marriage Problems }\end{array}$} & \multicolumn{2}{|c|}{ United Families } & \multicolumn{2}{|c|}{ Divided Families } \\
\hline & $\begin{array}{c}\text { Total } \\
\text { Responses }\end{array}$ & $\begin{array}{c}\text { Percentage } \\
\text { of Total }\end{array}$ & $\begin{array}{c}\text { Total } \\
\text { Responses }\end{array}$ & $\begin{array}{c}\text { Percentage } \\
\text { of Total }\end{array}$ \\
\hline $\begin{array}{c}\text { Have seriously con- } \\
\text { sidered divorce }\end{array}$ & 89 & 7.7 & 14 & 17.3 \\
\hline $\begin{array}{l}\text { Have considered di- } \\
\text { vorce but not } \\
\text { seriously }\end{array}$ & 150 & 13.0 & 20 & 24.7 \\
\hline Never considered divorce & 742 & 64.2 & 37 & 45.7 \\
\hline No answer & 174 & 15.1 & 10 & 12.3 \\
\hline TOTAL & 1155 & 100.0 & 81 & 100.0 \\
\hline
\end{tabular}

TABLE 85

CORRELATION BETWEEN THE CONTEMPLATION OF DIVORCE AS SOLUTION TO MARRIAGE PROBLEMS AND SEX OF RESPONDENT

\begin{tabular}{|c|c|c|c|}
\hline \multirow{3}{*}{$\begin{array}{l}\text { Degree of ontemplation of } \\
\text { ivorce as a olution } \\
\text { to arriage roblems }\end{array}$} & \multicolumn{3}{|c|}{ Percentage of Responses } \\
\hline & \multirow{2}{*}{ 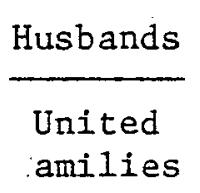 } & \multicolumn{2}{|c|}{ Wives } \\
\hline & & $\begin{array}{l}\text { United } \\
\text { amilies }\end{array}$ & $\begin{array}{l}\text { Divided } \\
\text { amilies }\end{array}$ \\
\hline Have seriously contemplated divorce & 6.6 & 8.9 & 18.7 \\
\hline $\begin{array}{l}\text { Have considered divorce, but not } \\
\text { seriousiy }\end{array}$ & 9.2 & 16.9 & 24.0 \\
\hline Never considered divorce & 68.5 & 59.9 & 45.3 \\
\hline No answer & 15.7 & 14.3 & 12.0 \\
\hline TOTAL & 100.0 & 100.0 & 100.0 \\
\hline
\end{tabular}

Note: The percentages given above do not show the husbands' responses from the divided homes. (The number, 6 out of 81 is too small to be significant.) 
In both tables, the percentage of divided home spouses who had contemplated divorce was significantly higher than that of united family spouses. When the 18.7 percent of the wives of divided families is compared to the 8.9 percent of the wives and the 6.6 percent of the husbands of united families something of the inner stresses and heartaches of the spouses (largely wives) of these divided families can be somewhat appreciated.

Satisfaction of Adventist Spouses with Sexual Relations in their Marriage

The fact that each questionnaire carried an identification number no doubt caused quite a large percentage of the spouses to refrain from filling in the question concerning satisfaction with sexual relations in marriage. In all, 15.9 percent of the husbands and 17.8 percent of the wives did not answer the question.

According to the data in table 86 , by far the largest percentage of both husbands and wives stated that they were very satisfied with their married sex life. About 10 percent of the total expressed some dissatisfaction with this area of their married life. When the figures were adjusted to exclude those who did not answer this question, the percentage of Adventist couples who expressed dissatisfaction increased to 12.8 percent for the husbands and 12.1 percent for the wives.

Although the percentages of husbands and wives who expressed dissatisfaction with the sexual relations in their marriage was relatively small, it may be that these figures do not describe the complete picture. It is possible that if a completely secret and 
accurate response could be secured, the 10 to 12 percent of Adventist spouses who expressed dissatisfaction in this area of their marriage might double or triple. In any case, those who would strengthen the Adventist family cannot safely ignore this area of marriage.

TABLE 86

SATISFACTION WITH SEXUAL RELATIONS IN MARRIAGE

\begin{tabular}{|c|c|c|c|c|}
\hline \multirow{2}{*}{$\begin{array}{c}\text { Expression of Sexual } \\
\text { Satisfaction in } \\
\text { Marriage Relations }\end{array}$} & \multirow{2}{*}{$\frac{\text { Husbands' }}{\text { Total }}$} & \multirow{2}{*}{$\begin{array}{c}\text { Responses } \\
\begin{array}{c}\text { Percentage } \\
\text { of Total }\end{array}\end{array}$} & \multicolumn{2}{|c|}{ Wives' Responses } \\
\hline & & & $\begin{array}{c}\text { Total } \\
\text { Responses }\end{array}$ & $\begin{array}{c}\text { Percentage } \\
\text { of Total }\end{array}$ \\
\hline Very satisfied & 424 & 73.4 & 415 & $72: 3$ \\
\hline Not too satisfied & 34 & 5.9 & 37 & 6.4 \\
\hline Dissatisfied & 26 & 4.5 & 16 & 2.8 \\
\hline $\begin{array}{l}\text { A cause of major } \\
\text { problems }\end{array}$ & 2 & .3 & 4 & .7 \\
\hline No answer & 92 & 15.9 & 102 & 17.8 \\
\hline TOTAL & 578 & 100.0 & 574 & 100.0 \\
\hline
\end{tabular}

Degree of Understanding and Communication Between Spouses

When a man and woman stand before a minister and are declared to be husband and wife, they are in Biblical terms declared to be "one flesh." Although legally and morally this unity may exist, in practical terms oneness comes about not in a moment of time but as a result of a deepening understanding and close fellowship over an extended period of time. And this understanding between husband and wife grows as meaningful communication expands to include a 
physical, spiritual, emotional, and intellectual blending of the two individuals until the two truly become one. Unfortunately, few married couples achieve this degree of unity and happiness in their marriage.

Table 87 records the responses of Japanese Adventist couples as to how they evaluate the level of understanding and communication existing between themselves and their spouse. The great majority of united family spouses, that is 68.1 percent, considered this aspect of their relationship to be either good or excellent. Although the percentage of divided family spouses was lower, 55.6 percent reported the degree of understanding and communication between them and their spouse to be either good or excellent.

Perhaps the most significant data to be noticed in this table is the differences in perceived levels of uncerstanding between the spouses of united and divided families. In every category listed, divided family spouses showed a lesser degree of understanding and meaningful communication. Once again, this seems to point to the problems and tensions divided families experience and indicates the need for understanding and concern on the part of those interested in family evangelism.

\section{Marital Quarrelling and Conflict}

Among Adventist Couples

Poor communication and a lack of understanding between marriage partners often ends in quarrelling and conflict. Although differences will be evident whenever two mature, thinking individuals live in close proximity, this, to a certain extent is normal and 
TABLE 87

MUTUAL UNDERSTANDING AND LEVEL OF COMMUNICATION BETWEEN SPOUSES

\begin{tabular}{|c|c|c|c|c|}
\hline \multirow{2}{*}{$\begin{array}{l}\text { Degree of understanding } \\
\text { and Communication }\end{array}$} & \multicolumn{2}{|c|}{ United Families } & \multicolumn{2}{|c|}{ Divided Families } \\
\hline & $\begin{array}{c}\text { Total } \\
\text { Responses }\end{array}$ & $\begin{array}{l}\text { Percentage } \\
\text { of Total }\end{array}$ & $\begin{array}{c}\text { Total } \\
\text { Responses }\end{array}$ & $\begin{array}{l}\text { Percentage } \\
\text { of Total }\end{array}$ \\
\hline Poor & 18 & 1.6 & 3 & 3.7 \\
\hline Fair & 261 & 22.6 & 27 & 33.3 \\
\hline Good & 709 & 61.4 & 43 & 53.1 \\
\hline Excellent & 77 & 6.7 & 2 & 2.5 \\
\hline No answer & 90 & 7.8 & 6 & 7.4 \\
\hline TOTAL & 1155 & 100.0 & 81 & 100.0 \\
\hline
\end{tabular}

healthy. What is of concern, however, is when differences lead to heated conflicts which wound and separate the marriage partners. As can be seen in table 88 , Japanese Adventist couples are very human in this respect. Looking at the spouses of the united families one sees that nearly 10 percent claimed they never quarreled and 58 percent stated they argued and fought often, but not so heatedly as to affect the basic relationship between them. What is of concern is the 4.7 percent who quarreled often and heatedly, the 15.6 percent who seldom quarreled because they had so little in common, and the 3 percent who seldom quarreled or disagreed openly but were silently antagonistic and withdrawn.

Table 89 looks at the problem of quarreling in relation to the age of the marriage partners. Noticeable is the decrease in the percentages with the increase of age of those who reported quarreling 
TABLE 88

DEGREE OF QUARRELING BETWEEN

MARRIAGE PARTNERS

\begin{tabular}{|c|c|c|c|c|}
\hline \multirow[b]{2}{*}{ Degree of Quarreling } & \multicolumn{2}{|c|}{ United Families } & \multicolumn{2}{|c|}{ Divided Families } \\
\hline & $\begin{array}{c}\text { Total } \\
\text { Responses }\end{array}$ & $\begin{array}{l}\text { Percentage } \\
\text { of Total }\end{array}$ & $\begin{array}{c}\text { Total } \\
\text { Responses }\end{array}$ & $\begin{array}{c}\text { Percentage } \\
\text { of Total }\end{array}$ \\
\hline Often quarrel heatedly & 54 & 4.7 & 3 & 3.7 \\
\hline $\begin{array}{l}\text { Often quarrel but not } \\
\text { heatedly }\end{array}$ & 670 & 58.0 & 34 & 42.0 \\
\hline $\begin{array}{l}\text { Seldom quarrel--little } \\
\text { in common }\end{array}$ & 180 & 15.6 & 24 & 29.6 \\
\hline $\begin{array}{l}\text { Seldom quarrel--but } \\
\text { often silently } \\
\text { antagonistic }\end{array}$ & 35 & 3.0 & 2 & 2.5 \\
\hline Never quarrel & 113 & 9.8 & 14 & 17.3 \\
\hline No answer & 103 & 8.9 & 4 & 4.9 \\
\hline TOTAL & 1155 & 100.0 & 81 & 100.0 \\
\hline
\end{tabular}

often but not heatedly--a high of 77.8 percent for couples twenty-four years of age or less to a low of 41.9 percent for those sixty and over. Also of significance is the increase in the percentages of those who had little in common and thus seldom quarreled--a low of 5.6 percent in those twenty-four years of age or less to a high of 25.3 percent among couples who were between the ages of fifty and fifty-nine.

The percentage of spouses reporting they seldom argued because they had so little in common was 14 percentage points greater in divided families than in united families (see table 88). However, 
TABLE 89

CORRELATION BETWEEN DEGREE OF QUARRELING BETWEEN MARRIAGE PARTNERS AND AGE OF SPOUSES

\begin{tabular}{|c|c|c|c|c|c|c|}
\hline \multirow[b]{2}{*}{$\begin{array}{l}\text { Age in } \\
\text { Years }\end{array}$} & \multirow[b]{2}{*}{$\begin{array}{c}\text { Total } \\
\text { Responses }\end{array}$} & \multicolumn{5}{|c|}{ Percentage of Total } \\
\hline & & $\begin{array}{c}\text { Often Quarrel } \\
\text { Heatedly }\end{array}$ & $\begin{array}{c}\text { Often Quarrel } \\
\text { but not } \\
\text { Heatedly }\end{array}$ & $\begin{array}{l}\text { Seldom Quarrel-- } \\
\text { Little in Common }\end{array}$ & $\begin{array}{l}\text { Seldom Quarrel-- } \\
\text { Qften Silently } \\
\text { Antagonistic }\end{array}$ & $\begin{array}{c}\text { Never } \\
\text { Quarrel }\end{array}$ \\
\hline Under 24 & 18 & 5.6 & 77.8 & 5.6 & 5.6 & 5.6 \\
\hline $25-29$ & 102 & 6.9 & 67.6 & 7.8 & 3.9 & 8.8 \\
\hline $30-34$ & 181 & 7.2 & 64.6 & 11.0 & 1.7 & 9.9 \\
\hline $35-39$ & 172 & 7.0 & 65.7 & 10.5 & 3.7 & 7.0 \\
\hline $40-49$ & 305 & 3.6 & 62.0 & 13.4 & 2.0 & 11.1 \\
\hline $50-59$ & 186 & 2.2 & 47.3 & 25.3 & 4.3 & 10.8 \\
\hline 60 and over & 191 & 3.1 & 41.9 & 23.6 & 3.7 & 9.9 \\
\hline TOTAL & 1155 & & & & & \\
\hline \multicolumn{2}{|c|}{ MEAN PERCENTAGE } & 4.7 & 58.0 & 15.6 & 3.0 & 9.8 \\
\hline
\end{tabular}


the percentage of divided families claiming that they never quarreled with their spouses was nearly double that of united families. It may be that they belonged in the category of those who never quarreled because they had so little in common.

\section{Degree of Participation in Mutual}

Activities and Hobbies

Often a man is said to be "married to" his work or a wife is "wrapped up" in her children. Husbands and wives who do indeed become one and between whom a deep level of understanding develops take time to share common interests and activities.

To what extent did Adventist husbands and wives share mutual interests in the form of some activity or hobby aside from their work? By a small margin table 90 shows that Adventist spouses who had some form of mutually enjoyed activity or hobby were larger as a group than those who did not. It may be assumed however, that most of those who did not respond had no hobby or activity. When asked what some of their activities or hobbies were, the following were listed: mutual enjoyment of classical Japanese arts, such as caligraphy, ceramics, flower arrangements, classical folk music and dance, recitation of classical Chinese poetry and Japanese haiku (form of poetry), going to museums and art galleries; reading together, joining book discussion clubs, studying English literature; travel, driving, camping; nature study, vegetable gardening, bonsai or miniature gardening, raising tropical or exotic plants, walking, mountain climbing; hunting, fishing; photography, painting, interior designing; music, listening to records, going to concerts, -singing, 
learning and playing traditional Japanese instruments, such as shamisen and koto; participation in various sports such as badminton, skating, skiing, skin diving, cycling, tennis, swimming, ping pong; enjoying spectator sports, watching TV programs, shopping together; sharing in church activities, Pathfinder clubs, and helping in branch Sabbath Schools.

TABLE 90

MUTUAL HOBBY ENJOYED BY MARRIAGE PARTNERS

\begin{tabular}{lcc}
\hline Enjoyment of Hobby & $\begin{array}{c}\text { Total } \\
\text { Responses }\end{array}$ & $\begin{array}{c}\text { Percentage } \\
\text { of Total }\end{array}$ \\
\hline Have mutual hobby or activity & 443 & 38.4 \\
$\begin{array}{l}\text { Do not have mutual hobby or } \\
\text { activity }\end{array}$ & 410 & 35.5 \\
No answer & 302 & 26.1 \\
\hline ToTAL & 1155 & 100.0 \\
\hline
\end{tabular}

One eighty-year-old wife wrote in a bold hand in the space provided that the hobby and activity which she enjoyed with her husband was that of mountain climbing. Helping to discover and develop mutually enjoyable activities and hobbies could be one way to help strengthen Adventist families. 
CHAPTER IX

\section{DYNAMICS IN THE FAMILY}

The traditional Japanese family evolved from the classical, patriarchal, Confucian family of China and was based on filial piety and loyalty. It was however greatly modified by the feudal family with its patterned reciprocity of rights and duties between the authority figure, usually the father, and the other members of the family--much like that which existed between lord and vassals.

The Japanese family underwent further changes and modification during the Meiji restoration, beginning in 1853, and especially during the years since World War II. These changes affected the dynamics of the family and the position of the father and husband. The father's voice lost a good deal of its authority while the mother's gained proportionately.

To what extent were these changes and modifications which are taking place in the Japanese family reflected in Japanese Adventist families? Who holds the final authority and to what extent? Who controls the money in the home? Is there a difference in the dynamics existing in younger families as compared to the older ones? These and related questions are examined in this chapter.

\section{Position of Authority in Adventist Families}

To what extent the father and husband held final authority in the Adventist family was examined in tables 91, 92, and 93. 
Table 91 records the responses to the question regarding the authority in the families in which Adventist spouses were raised. Table 92 registers the responses to the question of final authority in their own homes. And table 93 examines the position of authority in Adventist homes in relation to the authority figure in the homes in which they were raised.

Very little change was seen in the position of the male parent as an authority figure from the families in which Adventist spouses were raised as compared to that of their own families. Husbands' responses indicated a slight decline in authority as compared to that of their fathers, from 64.5 percent to 59.0 percent (see tables 91 and 92). However, the wives perceived that their husband's authority had increased slightly from that of their father's, from 62.0 percent to 66.7 percent.

It is also interesting to notice the difference in responses of wives as compared to husbands concerning whom they perceived as holding the final authority. Whereas 66.7 percent of the wives said the husband was the boss, only 59.0 percent of the husbands felt that final authority rested with them. What this says is perhaps open to speculation.

It appears that two changes have taken place in the family authority pattern of Adventist families from the time of the parental home to that of the present families. One of these changes is the lessening of the perceived authority of the wife in Adventist homes today as compared to that of the wives' mothers of the preceeding generation, from 11.3 percent to 1.8 percent. The other is the 
TABLE 91

FINAL AUTHORITY OF HOMES IN WHICH ADVENTIST SPOUSES WERE RAISED

\begin{tabular}{|c|c|c|c|c|}
\hline \multirow{2}{*}{$\begin{array}{c}\text { Final Authority of } \\
\text { Parental Home }\end{array}$} & \multicolumn{2}{|c|}{ Total } & \multirow{2}{*}{$\frac{\begin{array}{c}\text { Husband } \\
\text { Responses }\end{array}}{\text { Percentage }}$} & \multirow{2}{*}{$\frac{\begin{array}{c}\text { Wife } \\
\text { Responses }\end{array}}{\text { Percentage }}$} \\
\hline & Responses & Percentage & & \\
\hline Father & 729 & 63.1 & 64.5 & 62.0 \\
\hline Mother & 131 & 11.3 & 10.7 & 11.8 \\
\hline Grandfather & 18 & 1.6 & 1.9 & 1.2 \\
\hline Grandmother & 9 & .8 & .9 & .7 \\
\hline $\begin{array}{l}\text { Joint parental } \\
\text { authority }\end{array}$ & 166 & 14.4 & 11.9 & 16.7 \\
\hline Clan consensus & 2 & .2 & .2 & .2 \\
\hline Other & 17 & 1.5 & 2.2 & .5 \\
\hline No answer & 83 & 7.2 & 7.6 & 6.8 \\
\hline TOTAL & 1155 & 100.1 & 99.9 & 9.9 .9 \\
\hline
\end{tabular}

increase in the shared parental authority between husband and wife, from 14.4 percent to 26.7 percent. It would seem that there has been a trend toward a joint approach toward authority in the Adventist family without a lessening of the position of the faither noticed in the preceeding generation.

Tables 91 and 92 indicate that there was little or no authority perceived in the extended family or clan consensus. Decline in the authority of the clan from its traditionally strong position had evidently taken place previous to the experience of the respondents. 
TABLE 92

FINAL AUTHORITY IN ADVENTIST HOMES TODAY

\begin{tabular}{|c|c|c|c|c|}
\hline \multirow{2}{*}{$\begin{array}{l}\text { Final Authority in } \\
\text { Adventist Homes }\end{array}$} & \multicolumn{2}{|c|}{ Total } & \multirow{2}{*}{$\begin{array}{c}\begin{array}{c}\text { Husband } \\
\text { Responses }\end{array} \\
\text { Percentage }\end{array}$} & \multirow{2}{*}{$\frac{\begin{array}{c}\text { Wife } \\
\text { Responses }\end{array}}{\text { Percentage }}$} \\
\hline & Responses & Percentage & & \\
\hline Husband. & 725 & 62.8 & 59.0 & 66.7 \\
\hline Wife & 21 & 1.8 & 2.4 & 1.2 \\
\hline Grandfather & 15 & 1.3 & .9 & 1.6 \\
\hline Grandmother & 7 & .6 & .2 & 1.0 \\
\hline $\begin{array}{l}\text { Joint parental } \\
\text { authority }\end{array}$ & 308 & 26.7 & 29.1 & 24.2 \\
\hline Clan consensus & 5 & .4 & .7 & .2 \\
\hline Other & 5 & .4 & .5 & .3 \\
\hline No answer & 69 & 6.0 & 7.3 & 4.7 \\
\hline TOTAL & 1155 & 100.0 & 100.1 & 99.9 \\
\hline
\end{tabular}

Table 93 indicates that there was a tendency on the part of the respondent spouses to continue in their own homes the pattern of authority learned in the homes in which they were raised. Thus among spouses raised in father-dominated homes, the husband was perceived as holding the final authority by a large margin, 72.6 percent as compared to 11.3 percent of wives who held the final authority. By contrast, among the spouses raised in mother-dominated families, the percentage of the husbands who held the final authority still was greater than that of wives but the percentage had decreased considerably, 52.4 percent as compared to 19.0 percent of the wives 
TABLE 93

CORRELATION BETWEEN FINAL AUTHORITY IN ADVENTIST HOMES TODAY AND AUTHORITY IN HOMES IN WHICH THEY WERE RAISED

\begin{tabular}{|c|c|c|c|c|c|c|c|c|c|}
\hline \multirow{2}{*}{$\begin{array}{c}\text { Final Authority } \\
\text { in Parental } \\
\text { Homes }\end{array}$} & \multicolumn{2}{|c|}{ Total } & \multicolumn{7}{|c|}{ Percentage of Total } \\
\hline & Responses & Percentage & Husband & Wife & $\begin{array}{l}\text { Grand- } \\
\text { father }\end{array}$ & $\begin{array}{l}\text { Grand- } \\
\text { mother }\end{array}$ & $\begin{array}{c}\text { Joint } \\
\text { Parental } \\
\text { Consensus }\end{array}$ & $\begin{array}{c}\text { Clan } \\
\text { Consensus }\end{array}$ & Other \\
\hline Father & 729 & 63.1 & 72.6 & 11.3 & 2.3 & 1.1 & 7.2 & .1 & 1.7 \\
\hline Mother ' & 131 & 11.3 & 52.4 & 19.0 & -- & $-\cdots$ & 23.8 & -- & --- \\
\hline Grandfather & 18 & 1.6 & 46.7 & 6.3 & $-\cdots$ & $-\infty$ & 33.3 & -- & 6.7 \\
\hline Grandmother & 9 & .8 & 14.3 & 57.1 & --- & 14.3 & 14.3 & -- & --- \\
\hline $\begin{array}{l}\text { Joint parental } \\
\text { authority }\end{array}$ & 166 & 14.4 & 51.3 & 9.7 & .6 & -- & 31.2 & .3 & 1.3 \\
\hline $\mathrm{Clan}$ consensus & 2 & .2 & 40.0 & 40.0 & --- & -- & 20.0 & -- & -- \\
\hline Other & 17 & 1.5 & 80.0 & 20.0 & $\therefore$ & -- & ---- & -- & --- \\
\hline No answer & 23 & 7.2 & 29.0 & 10.1 & -- & -- & 8.7 & -- & -- \\
\hline TOTAL & 1155 & 100.1 & & & & & & & \\
\hline MEAN PERCENTAGE & & & 62.8 & 1.8 & 1.3 & .6 & 26.7 & .4 & .4 \\
\hline
\end{tabular}


who held final authority: This tendency to continue the pattern of authority can also be seen among spouses who were raised in' homes in which their parents held joint authority. Among Adventist families, 31.2 percent of the spouses who were raised in homes with joint parental authority continued this same type of authority in their own homes. This is in contrast to 7.2 percent of Adventist families when the parental-home authority figure was the father and 23.8 percent when it was the mother.

Single Adventist young people were asked to respond to a similar question. Their responses as to who they considered as the final authority in the homes in which they were raised can be seen in table 102. Although they largely agreed with the spouses of Adventist homes as to the extent of jointly shared authority in their parental home, they disagreed with their parent's assessment as to the extent to which the father or mother held final authority. Whereas 62.8 percent of Adventist families said that in their homes the husband was the final authority figure, only 49.0 percent of single Adventist youth saw their father as holding final authority. And whereas only 1.8 percent of Adventist families reported that in their homes the wife held the authority, 10.9 percent of Adventist youth saw the mother as the final authority in their homes.

\section{Control of Finances in the Family}

The Japanese attitude toward the handling of money has been traditionally quite different from that in the West. Although times have changed, even today in modern Japan money is not always passed directly from hand to hand but is wrapped in tissue paper, concealed 
in an envelope, or placed on a tray. Traditionally, the handling of money was thought to be beneath the dignity of a man of authority. Traces of these attitudes toward money can still be found in Japanese society and in the Adventist family.

Tables 94 and 95 record the responses of Adventist couples as to who controlled the finances in their home. It can be seen that in only a small portion of families, that is 4.5 percent, did the husband assume entire control. This seems to indicate a continuing distaste of many men toward the handling of money. In nearly six out of ten families the wife took complete charge of family finances, or at least handled the day to day expenditure of funds. In about one out of three of the families husbands and wives took joint control of family finances. The responses of the husbands and wives were only slightly different.

The control of finances of Adventist families when correlated with the age of the respondent seems to indicate some change in attitude toward the handling of funds (see table 95). Younger couples seem more inclined to handle their funds jointly or the husband has final authority in major items while the wife handles the day to day finances. Those sixty years of age or older showed a greater tendency than did younger couples toward placing the final authority in the hands of the husband.

\section{Attitudes of Adventist Spouses Toward the Wife Working Outside the Home}

Tables 96 and 97 tabulate the responses of Adventist family spouses concerning their attitudes toward wives working outside the 
TABLE 94

CONTROL OF FAMILY FINANCES

\begin{tabular}{|c|c|c|c|c|}
\hline \multirow{2}{*}{$\begin{array}{c}\text { Control of Finances } \\
\text { of Family }\end{array}$} & \multicolumn{2}{|c|}{ Total } & \multicolumn{2}{|c|}{$\begin{array}{l}\text { Percentage } \\
\text { of Total }\end{array}$} \\
\hline & Responses & Percentage & Husb ands & Wives \\
\hline $\begin{array}{l}\text { Husband almost entirely, } \\
\text { with allowance for wife }\end{array}$ & 52 & 4.5 & 4.2 & 4.9 \\
\hline $\begin{array}{l}\text { Husband controls major } \\
\text { items, wife handles } \\
\text { daily finances }\end{array}$ & 433 & 37.5 & 35.3 & 39.5 \\
\hline $\begin{array}{l}\text { Wife almost entirely, } \\
\text { with allowance for } \\
\text { husband }\end{array}$ & 250 & 21.6 & 23.0 & 20.4 \\
\hline Joint control & 362 & 31.3 & 31.7 & 31.0 \\
\hline Other & 12 & 1.0 & 1.6 & .5 \\
\hline No answer & 46 & 4.0 & 4.3 & 3.7 \\
\hline TOTAL & 1155 & 99.9 & 100.1 & 100.0 \\
\hline
\end{tabular}

home. The percentage of wives who disapproved of the mother working while the children were small was 54.6 percent. By contrast, 41.8 percent of the husbands disapproved of the mother working while the children were small. However, the percentage of the wives who on no account would agree to the wife working outside the home was 11.9 percent or about half that of their husbands, which was 22.8 percent. Perhaps the women were less adamant and more practical in their attitudes, or perhaps male pride had something to do with the rather large percentage who stated they would never agree to their wives working. 
TABLE 95

CORRELATION BETWEEN CONTROL OF FAMILY FINANCES AND AGE OF MARRIAGE PARTNERS

\begin{tabular}{|c|c|c|c|c|c|c|}
\hline \multirow[b]{2}{*}{ Age in Years } & \multirow[b]{2}{*}{$\begin{array}{c}\text { Total } \\
\text { Responses }\end{array}$} & \multicolumn{5}{|c|}{ Percentage of Total } \\
\hline & & $\begin{array}{l}\text { Husbands Almost } \\
\text { Entirely, Allow- } \\
\text { ance for Wife }\end{array}$ & $\begin{array}{c}\text { Husband Controls } \\
\text { Major Items, Wife } \\
\text { Handles Daily } \\
\text { Finances }\end{array}$ & $\begin{array}{l}\text { Wife Almost En- } \\
\text { tirely, with } \\
\text { Allowance for } \\
\text { Husband }\end{array}$ & $\begin{array}{c}\text { Join } \\
\text { Control }\end{array}$ & other \\
\hline 24 years and under & 18 & $-\cdots$ & 44.4 & 5.6 & 50.0 & $-\cdots$ \\
\hline $25-29$ & 102 & 2.9 & 36.3 & 34.3 & 24.5 & 1.0 \\
\hline $30-34$ & 181 & 3.3 & 45.3 & 23.2 & 23.8 & 1.7 \\
\hline $35-39$ & 172 & 1.2 & 48.8 & 22.1 & 24.4 & .6 \\
\hline $40-49$ & 305 & 4.3 & 35.7 & 21.0 & 36.7 & .3 \\
\hline $50-59$ & 186 & 3.8 & 29.6 & 22.6 & 39.8 & 1.1 \\
\hline 60 years and over & 191 & 11.0 & 30.4 & 14.7 & 29.8 & 2.1 \\
\hline TOTAL & 1155 & & & & & \\
\hline MEAN PERCENTAGE & & 4.5 & 37.5 & 21.6 & 31.3 & 1.0 \\
\hline
\end{tabular}


TABLE 96

ATTITUDE TOWARD WIFE WORKING

OUTSIDE THE HOME

\begin{tabular}{|c|c|c|c|c|}
\hline \multirow{2}{*}{$\begin{array}{c}\text { Attitudes Toward the } \\
\text { Wife Working }\end{array}$} & \multicolumn{2}{|c|}{ Total } & \multicolumn{2}{|c|}{ Percentages } \\
\hline & Responses & Percentage & $\begin{array}{l}\text { Husbands } \\
\text { Responses }\end{array}$ & $\begin{array}{c}\text { Wives' } \\
\text { Responses }\end{array}$ \\
\hline $\begin{array}{l}\text { Approve if husband and } \\
\text { wife agree }\end{array}$ & 256 & 25.9 & 28.4 & 23.0 \\
\hline $\begin{array}{l}\text { Disapprove while } \\
\text { children are small }\end{array}$ & 468 & 47.4 & 41.8 & 54.0 \\
\hline Never agreeable & 176 & 17.8 & 22.8 & 11.9 \\
\hline Other & 38 & 3.8 & 4.9 & 2.7 \\
\hline No answer & 50 & 5.1 & 2.2 & 8.4 \\
\hline TOTAL & 988 & 100.0 & 100.1 & 100.0 \\
\hline
\end{tabular}

Single Adventist youth seemed more idealistic and perhaps less practical in their responses to the same question, as can be seen in table 112. Thirty-nine percent of single Adventist young men and 33.8 percent of the young women stated they would never agree in any case to the wife working outside the home. However, it seems that marriage and having children of ones own greatly modified this idealism. Table 97 indicates that only 5.6 percent of young married couples twenty-four years of age and under stated that they would never agree to the wife working. The older the marriage partners were the larger the percentage who stated they would never approve of the wife working. The largest percentage of those who disapproved of the mother working outside the home when the children were small were among spouses between the ages of twenty-five and 
TABLE 97

CORRELATION BETWEEN ATTITUDE TOWARD WIFE WORKING OUTSIDE THE HOME AND AGE OF ADVENTIST SPOUSE

\begin{tabular}{|c|c|c|c|c|c|c|}
\hline \multirow{2}{*}{ Age in Years } & \multirow{2}{*}{$\begin{array}{c}\text { Total } \\
\text { Responses }\end{array}$} & \multicolumn{5}{|c|}{ Percentage of Total } \\
\hline & & $\begin{array}{l}\text { Approve if } \\
\text { Husband and } \\
\text { Wife Agree }\end{array}$ & $\begin{array}{c}\text { Disapprove While } \\
\text { Children are } \\
\text { Small }\end{array}$ & $\begin{array}{c}\text { Never } \\
\text { Agreeable }\end{array}$ & other & $\begin{array}{c}\text { No } \\
\text { Answer }\end{array}$ \\
\hline 24 years and under & 18 & 33.3 & 46.7 & 5.6 & 11.1 & 16.7 \\
\hline $25-29$ & 102 & 24.4 & 62.2 & 10.0 & 3.3 & 11.8 \\
\hline $30-34$ & 181 & 23.5 & 59.6 & 16.3 & .6 & 8.3 \\
\hline $35-39$ & 172 & 15.1 & 71.2 & 13.0 & .7 & 15.1 \\
\hline $40-49$ & 305 & 29.2 & 45.1 & 19.8 & 5.8 & 15.7 \\
\hline $50-59$ & 186 & 33.3 & 34.7 & 26.5 & 5.4 & 21.0 \\
\hline 60 years and over & 191 & 38.3 & 29.2 & 25.8 & 6.7 & 37.2 \\
\hline TOTAL & 1155 & & & & & \\
\hline MEAN PERCENTAGE & & 22.3 & 40.5 & 15.3 & 3.3 & 18.5 \\
\hline
\end{tabular}


thirty-nine. This would be during the years when the children in the home presented the biggest problem in care and training.

\section{Extent of Acquaintance and Intimate}

\section{Friendship with Neighbors}

The dynamics of friendship is a two-way street. Knowing who a person's intimate friends are reveals much of the influences that will affect that person's thinking, attitudes, and behavior. It also gives information concerning the sphere of his influence. Seventh-day Adventists have often been stigmatized, perhaps with ample justification, as being clannish and aloof, as having as little intimate contact with non-members as possible. Seventh-day Adventist spouses were asked the question concerning the extent of their involvement and friendship with their non-Adventist neighbors. A study of their responses could indicate the possibility Adventist families have of being influenced by their neighbors, and also their potential for influencing their non-Adventist neighbors in favor of Christianity and the church.

Table 98 summarizes the responses of both united and divided family spouses to the question concerning their involvement and friendship with their non-Adventist neighbors. By far the largest percentage, around 75 percent of the spouses of both united and divided families, reported that they had about an equal number of friends among members and non-members alike. The united family spouses who reported that their intimate friends were largely church members were nearly three times that of those who reported that their close friends were mainly non-members. Divided families 
reporting that their intimate friends were largely church members were identical in number to those reporting that they were nonmembers. The potential for witnessing to the power of the gospel and enlarging the membership of the church which these statistics indicate should not be overlooked.

TABLE 98

EXTENT OF FRIENDSHIP OF ADVENTIST

FAMILIES WITH NEIGHBORS

\begin{tabular}{|c|c|c|c|c|}
\hline \multirow{2}{*}{$\begin{array}{c}\text { Extent of Friendship } \\
\text { with Neighbors }\end{array}$} & \multicolumn{2}{|c|}{ United Families } & \multicolumn{2}{|c|}{ Divided Families } \\
\hline & $\begin{array}{c}\text { Total } \\
\text { Responses }\end{array}$ & $\begin{array}{c}\text { Percentage } \\
\text { of Total }\end{array}$ & $\begin{array}{c}\text { Total } \\
\text { Responses }\end{array}$ & $\begin{array}{c}\text { Percentage } \\
\text { of Total }\end{array}$ \\
\hline $\begin{array}{l}\text { Very little, intimate } \\
\text { friends largely church } \\
\text { members }\end{array}$ & 171 & 14.8 & 8 & 9.9 \\
\hline $\begin{array}{c}\text { To a great extent, our } \\
\text { intimate friends are } \\
\text { largely non-members }\end{array}$ & 55 & 4.8 & 8 & 9.9 \\
\hline $\begin{array}{l}\text { Have about an equal } \\
\text { number of friends } \\
\text { among members and } \\
\text { non-members }\end{array}$ & 857 & 74.2 & 61 & 75.3 \\
\hline No answer & 72 & 6.2 & 4 & 4.9 \\
\hline TOTAL & 1155 & 100.0 & 81 & 100.0 \\
\hline
\end{tabular}


CHAPTER X

\section{FAMILY-RELATED VIEWS OF UNMARRIED}

ADVENTIST YOUTH

A truly meaningful study of the Japanese Adventist family must not only delve into the historical and cultural roots of its past and attempt to describe and analyze its present attitudes and behavior, but it should also seek to discover what it is becoming and is likely to become in the future. The responses to the primary survey instrument, the Adventist Family Survey, have been recorded and analyzed briefly in chapters $V$ through IX. In this chapter, the attitudes of single Adventist youth between the ages of eighteen and thirty-five will be noted.

The 192 unmarried Adventist young people who answered the survey questionnaire came from each of the six districts into which the Japan Union Mission of Seventh-day Adventists is divided. The questionnaires were sent to the leaders of each district, who in turn sent them on to a number of representative churches in their districts for distribution to the youth. Thus the responses represent an available sample. About 20 percent of the youth surveyed were at the time in attendance at the denominationally sponsored Saniku Gakuin College or High School located in Chiba Ken. 
Selected Biographical Information

Concerning Single Adventists

Table 99 gives a summary of the responses of 192 single youth. As can be seen, each of the six districts was represented although not in exact proportion to that of the church membership of that district. No attempt was made to secure by means of a random or other selection of respondents the precise ratio of single Adventist youth in each district. By comparing the percentage of responses received from each district as shown in table 99 with table 2 , it can be seen that a larger percentage of responses were received proportionately from the Hokkaido district and a smaller percentage from the Kanto district than the church membership of those districts would indicate. However, although the responses received may not accurately reflect the opinions of Adventist youth, it does give some indication as to their attitudes. About three out of ten of the respondents were male and seven were female. This is very close to the 27.4 percent male and 72.6 percent female membership of the Seventh-day Adventist church in Japan at large, as indicated in figure 3.

An arbitrary age limit of eighteen to thirty-five was chosen for the youth surveyed. Responses were received in fair numbers from each of the four age categories with the largest percentage coming from among the twenty-one through twenty-five year olds and the smallest percentage from among the thirty-one to thirty-five year olds.

Looking at the education level of the youth, it can be seen that the largest percentage, over 50 percent, had a senior high 
TABLE 99

SELECTED CHARACTERISTICS OF SINGLE

ADVENTIST YOUTH

\begin{tabular}{|c|c|c|c|}
\hline & Categories of Respondents & $\begin{array}{l}\text { Number of } \\
\text { Responses }\end{array}$ & $\begin{array}{c}\text { Percentage } \\
\text { of Total }\end{array}$ \\
\hline District & $\begin{array}{l}\text { Hokkaido } \\
\text { Tohoku } \\
\text { Kanto } \\
\text { Chubu } \\
\text { Nishi-Nihon } \\
\text { Okinawa }\end{array}$ & $\begin{array}{r}26 \\
8 \\
50 \\
48 \\
47 \\
13\end{array}$ & $\begin{array}{r}13.5 \\
4.2 \\
26.0 \\
25.0 \\
24.5 \\
6.8\end{array}$ \\
\hline Sex & $\begin{array}{l}\text { Male } \\
\text { Female }\end{array}$ & $\begin{array}{r}59 \\
133\end{array}$ & $\begin{array}{l}30.7 \\
69.3\end{array}$ \\
\hline Age & $\begin{array}{l}20 \text { years or under } \\
21-25 \\
26-30 \\
31-35 \\
\text { No answer }\end{array}$ & $\begin{array}{r}40 \\
68 \\
62 \\
21 \\
1\end{array}$ & $\begin{array}{r}20.8 \\
35.3 \\
32.3 \\
10.9 \\
.5\end{array}$ \\
\hline $\begin{array}{c}\text { Education } \\
\text { level }\end{array}$ & $\begin{array}{l}\text { Junior high school } \\
\text { Senior high school } \\
\text { Junior college } \\
\text { Specialized or trade school } \\
\text { Senior college } \\
\text { University or other } \\
\text { No answer }\end{array}$ & $\begin{array}{r}11 \\
103 \\
25 \\
31 \\
16 \\
5 \\
1\end{array}$ & $\begin{array}{r}5.7 \\
53.6 \\
13.0 \\
16.2 \\
8.3 \\
2.6 \\
.5\end{array}$ \\
\hline $\begin{array}{l}\text { Adventist } \\
\text { education } \\
\text { obtained }\end{array}$ & $\begin{array}{l}\text { None at all } \\
\text { A1l education in Adventist schools } \\
\text { Some education in Adventist school } \\
\text { No answer }\end{array}$ & $\begin{array}{r}86 \\
12 \\
90 \\
4\end{array}$ & $\begin{array}{r}44.8 \\
6.3 \\
46.9 \\
2.1\end{array}$ \\
\hline Occupation & $\begin{array}{l}\text { Student } \\
\text { Ronin student } \\
\text { Employed--largely skilied } \\
\text { Employed--largely manual } \\
\text { Unemployed } \\
\text { Other } \\
\text { No answer }\end{array}$ & $\begin{array}{r}59 \\
3 \\
65 \\
25 \\
15 \\
1 \\
6\end{array}$ & $\begin{array}{r}30.7 \\
1.6 \\
33.9 \\
13.0 \\
7.8 \\
.5 \\
3.1\end{array}$ \\
\hline $\begin{array}{l}\text { Religious } \\
\text { Background }\end{array}$ & $\begin{array}{l}\text { No religion } \\
\text { Nominal Japanese religion } \\
\text { Strict Japanese religion } \\
\text { Nominal non-SDA Christian } \\
\text { Strict non-SDA Christian } \\
\text { One parent SDA Christian } \\
\text { Both parents SDA Christians } \\
\text { No answer }\end{array}$ & $\begin{array}{r}20 \\
74 \\
9 \\
2 \\
1 \\
40 \\
43 \\
3\end{array}$ & $\begin{array}{r}10.4 \\
38.5 \\
4.7 \\
1.0 \\
.5 \\
20.8 \\
22.4 \\
1.6\end{array}$ \\
\hline \multicolumn{2}{|c|}{ TOTAL RESPONSES } & 192 & \\
\hline
\end{tabular}


school education. A rather small percentage, 5.7 percent, were junior highrschool graduates, and about twice that percentage, 10.9 percent, had a four-year college education or more. It is felt that this rather accurately represents the scholastic attainments of Adventist youth throughout Japan.

The question was asked as to how much of their total education from first grade through college was received in an Adventist school. Table 99 shows that just a little over 50 percent had received all or some of their education in Adventist schools. Perhaps the 44.8 percent who had never attended Adventist schools reflects the fact that a large number of these young people came from non-Adventist homes and had had no opportunity to attend Adventist schools.

Three out of ten of the respondents listed themselves as students or ronin, the latter term referring to individuals who had sought entrance into some university or specialized school but who were up to that point unsuccessful in gaining admission. The largest group of Adventist youth were already employed in some type of work, either largely intellectual and skilled or manual.

The religious background of the homes in which these youth were raised is also indicated in table 99. Roughly speaking, the religious background of the homes from which they came was as follows: one out of ten had no religious home influence of any kind, four out of ten came from homes with a largely Buddhist, Shinto, or other Japanese religious influence, one out of ten came from a non-Adventist Christian home, and four out of ten were 
raised in homes in which there was some Adventist influence with either one or both parents being Adventist church members.

The fact that over half of the Adventist youth of the church entered the church without the influence of a Christian home should be a source of satisfaction and a subject of concern at the same time. It should be a source of satisfaction and encouragement that the church is appealing to so many youth. At the same time it should cause concern as to how to best help ... . these single youth to establish strong Adventist homes that will be happy and stable for both marriage partners. An effort should also be made to help young people make their homes representative, active, and fruitful; homes that will nurture their own Christian stability and will pass on the Adventist truth to their children.

Happiness of the Parental Home as Viewed by Single Adventist Youth

One of the areas investigated in the Adventist Family Survey was the personal evaluation by the marriage partners of the success and happiness of their own marriages. Tables 68 through 80 recorded and analyzed these responses. It was seen that in the united families, 41.9 percent of the marriage partners considered their marriages to be very satisfactory and that one-tenth of one percent reported theirs to be very unhappy. Comparison of these responses to those of the single youth who evaluated the happiness of the homes in which they were raised, as shown in tables 100, 101 and 102, is revealing. According to the responses of single youth, the percentage of those reporting they were raised in very happy homes was considerably 
less than that of Adventist husbands and wives who reported they. were very satisfied with the happiness level of their marriage. Also, the percentage reporting that their parental home was very unhappy was greater than the percentage of united family spouses that reported their marriage to be very unhappy. This perhaps could indicate that the single youth, reporting on matters less personal to themselves, were more objective than were the married couples and thus more nearly accurate in reporting the actual situation. Or perhaps it is a reflection of the opinions of the large percentage of youth who were raised in non-Adventist homes who perceived their homes to be less happy than those in which both parents were Adventists. In comparing the responses of the single men and women, as given in table 100, it can be noticed that the young men rated their homes happier than did the young women. The percentage of young women reporting the homes in which they were raised as very unhappy was exactly double that of the young men. Possibly this suggests that just as with husbands and wives of united families, whose responses were indicated in table 68, the single young women were more sensitive to feelings of happiness or conflict between marriage partners.

Table 101 records and analyzes the responses of single youth concerning the perceived happiness in their parental homes according to the age of the respondent. The very young were seen as much more inclined to view their homes as happy in comparison to the older youth. Whereas 32.5 percent of those who were twenty years of age or under considered their homes to be very happy and 
TABLE 100

SINGLE ADVENTIST YOUTH'S EVALUATION OF

THE HAPPINESS OF THE HOME IN WHICH

THEY WERE RAISED

\begin{tabular}{|c|c|c|c|c|}
\hline & \multicolumn{2}{|c|}{ Men's Responses } & \multicolumn{2}{|c|}{ Women's Responses } \\
\hline & Total & Percentage & Total & Percentage \\
\hline Very happy & 10 & 16.9 & 20 & 15.0 \\
\hline Relatively happy & 33 & 55.9 & 69 & 51.9 \\
\hline Relatively unhappy & 8 & 13.6 & 21 & 15.8 \\
\hline Very unhappy & 2 & 3.4 & 9 & 6.8 \\
\hline No answer & 6 & 10.2 & 14 & 10.5 \\
\hline TOTAL & 59 & 100.0 & 133 & 100.0 \\
\hline
\end{tabular}

TABLE 101

CORRELATION BETWEEN SINGLE ADVENTIST YOUTH'S

EVALUATION OF THE HAPPINESS OF THE HOME IN

WHICH THEY WERE RAISED AND AGE

OF RESPONDENTS

\begin{tabular}{|c|c|c|c|c|c|}
\hline \multirow{2}{*}{ Age in Years } & \multirow{2}{*}{$\begin{array}{c}\text { Total } \\
\text { Responses }\end{array}$} & \multicolumn{4}{|c|}{ Percentage of Total } \\
\hline & & $\begin{array}{l}\text { Very } \\
\text { Happy }\end{array}$ & $\begin{array}{c}\text { Relatively } \\
\text { Happy }\end{array}$ & $\begin{array}{c}\text { Relatively } \\
\text { Unhappy }\end{array}$ & $\begin{array}{c}\text { Very } \\
\text { Unhappy }\end{array}$ \\
\hline 20 years or under & 40 & 32.5 & 62.5 & 2.5 & --- \\
\hline $21-25$ & 68 & 14.7 & 63.2 & 13.2 & 2.9 \\
\hline $26-30$ & 62 & 9.7 & 45.2 & 19.4 & 11.3 \\
\hline $31-35$ & 21 & 4.8 & 28.6 & 33.3 & 9.5 \\
\hline TOTAL & 191 & & & & \\
\hline MEAN PERCENTAGE & & 15.6 & 53.1 & 15.1 & 5.7 \\
\hline
\end{tabular}


none reported them to be very unhappy, those in the thirty-one to thirty-five age bracket reported only 4.8 percent parental homes that were very happy, and 9.5 percent remembered the home in which they were raised as very unhappy.

The noticeable difference in reporting the happiness level of their homes in relation to the age of the youth could seem to indicate either an actual change in the happiness level of the homes or a change in the attitude of the young person toward those conditions as they existed in the home. The latter would more likely seem to be true.

Table 102 reports the responses of single Adventist youth concerning the perceived happiness of the homes in which they were raised according to the religious background of their homes. Some of the categories of religious background had so few total responses that the percentages cannot be considered as accurate reflections of the evaluation of the youth of these homes. However, certain trends may be significant, especially in categories with a larger number of responses. Those families in which both parents were Adventist church members were reported by 30.2 percent to have been very happy. This is three times the percentage of single youth who were raised in families with one parent an Adventist and who reported their home to be very happy. Not only was the one-parent Adventist family less happy than the family where both parents were Adventists, but it was less happy than those families with no religious influence in the home at all or in which the influence was that of a strict Japanese religion. This may indicate the conflict that a divided home often produces. 
TABLE 102

CORRELATION BETWEEN SINGLE ADVENTIST YOUTH'S EVALUATION OF THE HAPPINESS

OF THE HOME IN WHTCH THEY WERE RAISED AND THE RELIGIOUS BACKGROUND OF THEIR PARENTAL HOME

\begin{tabular}{|c|c|c|c|c|c|c|}
\hline \multirow{2}{*}{$\begin{array}{l}\text { Religious Background } \\
\text { of Single Youth }\end{array}$} & \multirow{2}{*}{$\begin{array}{c}\text { Total } \\
\text { Responses }\end{array}$} & \multicolumn{5}{|c|}{ Percentage of Responses } \\
\hline & & $\begin{array}{l}\text { Very } \\
\text { Happy }\end{array}$ & $\begin{array}{c}\text { Relatively } \\
\text { Happy }\end{array}$ & $\begin{array}{l}\text { Relative1y } \\
\text { Unhappy }\end{array}$ & $\begin{array}{l}\text { Very } \\
\text { Unhappy }\end{array}$ & $\begin{array}{c}\text { No } \\
\text { Answer }\end{array}$ \\
\hline No religion & 20 & 20.0 & 60.0 & 5.0 & 10.0 & 5.0 \\
\hline Nominal Japanese religion & 74 & 8.1 & 47.3 & 27.0 & 5.4 & 12.2 \\
\hline Strict Japanese religion & 9 & 22.2 & 55.6 & 11.1 & 11.1 & --- \\
\hline Nominal non-Adventist Christian & 2 & 50.0 & --- & ---- & 50.0 & --- \\
\hline Strict non-Adventist Christian & 1 & ---- & --- & --- & ---- & 100.0 \\
\hline One parent Adventist & 40 & 10.0 & 62.5 & 15.0 & 5.0 & 7.5 \\
\hline Both parents Adventist & 43 & 30.2 & 53.5 & 2.3 & 2.3 & $-\cdots$ \\
\hline No answer & 3 & --- & 66.7 & $\cdots$ & --- & 33.3 \\
\hline TOTAL & 192 & & & & & \\
\hline MEAN PERCENTAGE & & 15.6 & 53.1 & -15.1 & 5.7 & 10.4 \\
\hline
\end{tabular}


Final Authority in the Parental Home

as Viewed by Single Adventist

Youth

By comparing tables 103 and 104 with 91 and 92 , the attitudes of three generations toward the final authority in the home can be noted. Table 91 records the final authority in the parental homes of Adventist families as viewed by the husbands and wives in those families. Table 92 registers the responses of the husbands and wives as to who they considered as the authority in their own homes. And tables 103 and 104 note not only the opinion of single youth concerning the authority in their parental home but, looking forward to the future, consider who they see as the one who should hold that authority in their own home when they get married.

TABLE 103

SINGLE ADVENTIST YOUTH'S EVALUATION AS TO FINAL AUTHORITY IN PARENTAL HOME

\begin{tabular}{|c|c|c|}
\hline $\begin{array}{l}\text { Family Member } \\
\text { Who held Authority }\end{array}$ & Total Responses & Percentage of Total \\
\hline Father & 94 & 49.0 \\
\hline Mother & 21 & 10.9 \\
\hline Grandfather & 1 & .5 \\
\hline Grandmother & 1 & .5 \\
\hline Joint parental authority & 51 & 26.6 \\
\hline Clan consensus & 4 & 2.1 \\
\hline Other & 4 & 2.1 \\
\hline No answer & 16 & 8.3 \\
\hline TOTAL & 192 & 100.0 \\
\hline
\end{tabular}


TABLE 104

SINGLE ADVENTIST YOUTH'S OPINION AS TO THE

IDEAL DIVISION OF AUTHORITY BETWEEN

HUSBAND AND WIFE

\begin{tabular}{|c|c|c|c|c|}
\hline & \multicolumn{2}{|c|}{ Men's Responses } & \multicolumn{2}{|c|}{ Women's Responses } \\
\hline & Total & Percentage & Total & Percentage \\
\hline $\begin{array}{l}\text { Husband should have final au- } \\
\text { thority; wife should follow } \\
\text { his leadership completely }\end{array}$ & 5 & 8.5 & 3 & 2.3 \\
\hline $\begin{array}{l}\text { Husband and wife are equals } \\
\text { and should share equally in } \\
\text { all decisions }\end{array}$ & 12 & 20.3 & 44 & 33.1 \\
\hline $\begin{array}{l}\text { Husband and wife should share } \\
\text { the authority, but the final } \\
\text { authority should rest with } \\
\text { the husband }\end{array}$ & 39 & 66.1 & 75 & 56.4 \\
\hline No answer & 3 & 5.1 & 11 & 8.3 \\
\hline TOTAL & 59 & 100.0 & 133 & 100.1 \\
\hline
\end{tabular}

There seems to be little indication in these statistics to support a male-dominant position such as existed in the traditional Japanese family. Outwardly at least there seemed to be little difference, as reported in these figures, in the authority in the Japanese family as compared to that of the average Western family. There were, however, some slight differences in regard to the authority figure of the home as viewed by these three generations. First of all, as has already been pointed out, the single youth viewed their fathers as having less authority and their mother as having more authority than that reported by Adventist husbands and wives themselves. Second, there seems to be a trend toward a 
more democratic sharing of authority between the husband and the wife. Third, the dominant position of the clan-family in holding final authority and in decision-making in the family reached its nadir prior to the present generation. That it still held a slight hold on a minority of the individuals surveyed may be indicated by a slight increase in its position in the home as viewed by single Adventist youth.

Table 104 compares the attitudes of single young men and women toward the ideal division of authority in the home. The percentage of young men, 8.5 percent, as compared with young women, 2.3 percent, who approved of the traditional Japanese attitude of total husband-dominance in the home seems to indicate that the old traditions toward the male prerogative are not entirely dead. Perhaps as these single males get married their attitudes or at least their practices will conform more nearly to the norm in their parents' home.

It is also significant that the greatest percentage of single youth, 56.4 percent of the young women and 66.1 percent of the young men, saw the ideal as being a family in which the husband is the first among equals. That 5.1 percent of the men and 8.3 percent of the women did not answer this question also may indicate something. These may have felt that a dogmatic position before marriage was not wise, choosing rather to wait and see. 
Influences Affecting the Spiritual

Growth as Reported by Single

Adventist Youth

As important as making the initial decision to become a Christian is the question of Christian growth and discovering in one's own life those habits and practices that enhance spiritual growth and character development. Table 105 summarizes the answers of single Adventist young people to the question of the influences which had the greatest effect on their own spiritual growth and development.

TABLE. 105

SINGLE ADVENTIST YOUTHS' OPINION AS TO THE MOST HELPFUL INFLUENCES ON DEVELOPMENT

OF SPIRITUAL LIFE

\begin{tabular}{|c|c|c|c|c|}
\hline \multirow{2}{*}{$\begin{array}{l}\text { Most Helpful Influences } \\
\text { Affecting Spiritual Growth }\end{array}$} & \multicolumn{2}{|c|}{ Mens' Responses } & \multicolumn{2}{|c|}{ Womens' Responses } \\
\hline & Total & Percentage & Total & Percentage \\
\hline Sabbath sermon & 24 & 16.0 & 75 & 22.9 \\
\hline Sabbath school class & 18 & 12.0 & 28 & 8.6 \\
\hline Prayer meeting & 5 & 3.3 & 10 & 3.1 \\
\hline Personal daily devotions & 36 & 24.0 & 85 & 26.0 \\
\hline Religious radio programs & 3 & 2.0 & 1 & .3 \\
\hline Reading religious books & 43 & 28.7 & 91 & 27.8 \\
\hline Counseling with pastor & 5 & 3.3 & 10 & 3.1 \\
\hline Other & 14 & 9.3 & 23 & 7.0 \\
\hline No answer & 2 & 1.3 & 4 & 1.2 \\
\hline TOTAL & 150 & 99.9 & 327 & 100.0 \\
\hline
\end{tabular}


The most important influences for both young men and women were the same: reading religious books, daily personal devotions, the pastor's sermon on Sabbath morning, and the Sabbath school class. Although the order of these influences was the same, a decided difference in the emphasis placed on them by young men and women was noticed. Young women favored the pastor's sermon as an aid to spiritual development by 22.9 percent as compared to 16.0 percent for young men. On the other hand, young men favored the Sabbath School class by 12.0 percent to 8.6 percent for young women.

A careful study of the different emphasis given by young men and women toward the things that most influenced their spiritual growth should be helpful to church leaders in developing a program to assist young men and women in growing into mature and stable Christians. Husbands and wives of Adventist families indicated a similar trend in regard to differing influences of men and women (see table 58 ). These statistics suggest that religious influences affect men and women differently and in varying degree. It may also suggest that the different responses of men and women possibly stem from a basic difference in their natures and in their attitudes toward authority figures, such as preachers. Men seem to be more inclined to accept a statement on the basis of reason and logic, whereas women may accept it more on the basis of the authority of the one who made the statement. Careful consideration of these differences in men and women which are indicated by these statistics and a re-examination of the methods and messages employed by church 
pastors may be helpful in reaching and holding more men for Christ and the church.

\section{Attitudes toward Marriage Arrangements and Choosing of the Marriage Partner as Viewed by Single Adventist Youth}

Tables 106 through 112 record the answers to several questions concerning marriage. Table 106 asks about the method of choosing a marriage partner; table 107 considers the questions as to the form of the arrangements; tables 108 through 110 inquire into how important the young single Adventist feels it is that he or she marry within the church; table 111 questions the attitude toward marriage plans which parents' strongly opposed; and table 112 records what the Adventist young person feels would happen if he or she were to marry a nonmember.

According to traditional Japanese family dynamics and time honored custom, marriages were arranged by and for the family. The wishes of the individuals involved were always secondary to the good of the family. Changes in this method of choosing a marriage partner have often been noted by sociologists and have been indicated in the statistics recorded in t'ables 9,10 , and 11 of this report. To what extent these attitudes toward the choice of a marriage partner are reflected by single Adventist youth today is recorded in tables 106 and 107.

Not one of the young people questioned felt that the decision as to whom they should marry should be made by the parents alone, and only a very small percentage felt the parents had the right to veto a choice or decision made by the young people 
involved. By an overwhelming and almost identical percentage, 88 percent of the young men and women agreed that the choice as to a marriage partner should be made by the young people with the advice and approval of their parents. As seen in table 40, nearly the same percentage of Adventist parents who were surveyed ( 88.5 percent) responded similarly to the question as to how they felt their children's marriage partner should be chosen. However, the parents to a much larger extent felt that they should have the veto power over their children's choice of a marriage partner. Whereas only 1.7 percent of the young men and 2.3 percent of the young women felt the parents should have the power to veto their choices, 7.7 percent of the parents felt they should have veto power (compare table 106 with table 40).

TABLE 106

SINGLE YOUTHS' OPINION AS TO METHOD

OF CHOOSING MARRIAGE PARTNER

\begin{tabular}{|c|c|c|c|c|}
\hline \multirow[b]{2}{*}{$\begin{array}{l}\text { Method of Choosing } \\
\text { Marriage Partner }\end{array}$} & \multicolumn{2}{|c|}{ Young Men } & \multicolumn{2}{|c|}{ Young Women } \\
\hline & $\begin{array}{c}\text { Total } \\
\text { Responses }\end{array}$ & $\begin{array}{l}\text { Percentage } \\
\text { of Total }\end{array}$ & $\begin{array}{c}\text { Total } \\
\text { Responses }\end{array}$ & $\begin{array}{l}\text { Percentage } \\
\text { of Total }\end{array}$ \\
\hline $\begin{array}{l}\text { Decision made by indi- } \\
\text { viduals involved alone }\end{array}$ & 5 & 8.5 & 5 & 3.8 \\
\hline $\begin{array}{l}\text { Decision made with } \\
\text { parents' advice and } \\
\text { approval }\end{array}$ & 52 & 88.1 & 117 & 88.0 \\
\hline $\begin{array}{l}\text { Parents have the power } \\
\text { to veto decision }\end{array}$ & 1 & 1.7 & 3 & 2.3 \\
\hline Parents make the decision & - & -- & -- & -- \\
\hline No answer & 1 & 1.7 & 8 & 6.0 \\
\hline TOTAL & 59 & 100.0 & 133 & 100.1 \\
\hline
\end{tabular}


Table 107 indicates that when it came to whether the miai form of marriage (marriage arranged with the help of a third party go-between) or the renai form of marriage (marriage arranged without the help of a third party go-between) was preferred, the great majority said it made no difference which form was used. It would seem that although the traditional miai marriage form is still often used it is only a form. Thus even in this form of marriage arrangement the real choice of a marriage partner is largely that of the parties personally involved.

TABLE 107

SINGLE ADVENTIST YOUTH'S OPINION AS TO THE BEST FORM OF MARRIAGE ARRANGEMENT

\begin{tabular}{lccccc}
\hline \multirow{2}{*}{$\begin{array}{c}\text { Form of } \\
\text { Marriage Arrangement }\end{array}$} & Men's Responses & & Women's Responses \\
$\begin{array}{l}\text { Renai form of marriage } \\
\text { arrangements is best }\end{array}$ & 9 & 15.3 & & 19 & 14.3 \\
$\begin{array}{l}\text { Miai form of marriage } \\
\text { arrangements is best }\end{array}$ & 1 & 1.7 & & 3 & 2.3 \\
$\begin{array}{l}\text { Either one is fine, it } \\
\text { makes no difference }\end{array}$ & 48 & 81.4 & & 105 & 78.9 \\
$\begin{array}{l}\text { No answer } \\
\text { TOTAL }\end{array}$ & 1 & 1.7 & & 6 & 4.5 \\
\hline
\end{tabular}

One of the major interests and concerns of single young people everywhere is in finding the ideal marriage partner. Seventhday Adventist youth in particular find this a matter of deep concern. Because of their belief that the only kind of marriage that will be 
approved of God and that will lead to a genuinely happy Christian marriage is a marriage to a partner who is a Seventh-day Adventist church member, and because of the more than two to one ratio of women over men in the Adventist church in Japan, the finding of a marriage partner is, to single Adventist young women, a matter of real concern. Just how important single Adventist youth felt it was that they marry within the church can be seen in tables 108 through 110. The answers given by husbands and wives of Adventist families to a similar question can be noted and compared in tables 34 through 39.

Table 108 indicates that single Adventist youth were as much in harmony with the principle of marriage only within the church as were married Adventists. Comparable statistics show that 67.8 percent of single young men and 59.4 percent of single young women felt it was so important that they would on no account marry a non-church member. Table 40 indicates that 59.9 percent of the spouses of united families and 37.3 percent of those of divided families stated that they would never consent to their son or daughter marrying a non-member.

Looking at the other end of the table, the percentage of single youth who felt that it was not important whether the marriage partner was an Adventist church member or not was 6.8 percent, which was considerably higher than the 2.7 percent response from united Adventist families to a similar question. Finding a marriage partner seemed to be more of a concern to young Adventist women than to men (see table 108). A smaller percentage of young women 
than men stated that they would never marry a non-member, and a slightly larger percent said that they would not rule out, under certain circumstances, marriage to a non-member.

TABLE 108

SINGLE ADVENTIST YOUTH'S OPINIONS AS TO THE

IMPORTANCE OF MARRYING A SEVENTH-DAY

ADVENTIST CHURCH MEMBER

\begin{tabular}{|c|c|c|c|c|}
\hline \multirow{2}{*}{$\begin{array}{c}\text { The Importance of Marrying } \\
\text { an Adventist }\end{array}$} & \multicolumn{2}{|c|}{$\begin{array}{c}\text { Young } \\
\text { Men's Responses }\end{array}$} & \multicolumn{2}{|c|}{$\begin{array}{c}\text { Young } \\
\text { W.omen's R esponses }\end{array}$} \\
\hline & Total & Percentage & Total & Percentage \\
\hline $\begin{array}{l}\text { Very important, would never } \\
\text { marry a non-member }\end{array}$ & 40 & 67.8 & 79 & 59.4 \\
\hline $\begin{array}{l}\text { Very important, but would } \\
\text { not rule out marriage } \\
\text { to a non-member }\end{array}$ & 14 & 23.7 & 38 & 28.6 \\
\hline $\begin{array}{l}\text { Not too important, happines } \\
\text { is the most important }\end{array}$ & 2 & 3.4 & 8 & 6.0 \\
\hline Not important at all & 2 & 3.4 & 1 & .8 \\
\hline No answer & 1 & 1.7 & 7 & 5.3 \\
\hline TOTAL & 59 & 100.0 & 133 & 100.1 \\
\hline
\end{tabular}

Table 109 compares, according to the age of the respondents, the responses of single Adventist youth to this question of the importance of whether the marriage partner was a church member of not. Those twenty years of age or under seemed to be more liberal and less inclined to agree with this teaching of the church. Older youth who would be more likely to face a marriage problem would seem to be more apt to answer that marriage to a church member was 
TABLE 109

CORRELATION BETWEEN SINGLE ADVENTIST YOUTH'S OPINIONS AS TO THE

IMPORTANCE OF MARRYING A SEVENTH-DAY ADVENTIST CHURCH MEMBER AND AGE OF THE YOUNG PERSON

\begin{tabular}{|c|c|c|c|c|c|}
\hline \multirow[b]{2}{*}{ Age in Years } & \multirow{2}{*}{$\begin{array}{c}\text { Total } \\
\text { Responses }\end{array}$} & \multicolumn{4}{|c|}{ Percentage of Total } \\
\hline & & $\begin{array}{l}\text { Very Important, } \\
\text { Would Never } \\
\text { Marry a Non- } \\
\text { member. }\end{array}$ & $\begin{array}{l}\text { Very Important, } \\
\text { but Would not } \\
\text { Rule Out Marriage } \\
\text { to a Non-member. }\end{array}$ & $\begin{array}{l}\text { Not too Important, } \\
\text { Happiness is the } \\
\text { Most Important. }\end{array}$ & $\begin{array}{c}\text { Not Important } \\
\text { at A1l. }\end{array}$ \\
\hline 20 years or under & 40 & 57.5 & 27.5 & 12.5 & 2.5 \\
\hline $21-25$ & 68 & 64.7 & 23.5 & 4.4 & 1.5 \\
\hline $26-30$ & 62 & 64.5 & 32.3 & 1.6 & 1.6 \\
\hline $31-35$ & 21 & 57.1 & 23.8 & 4.8 & --- \\
\hline No answer & 1 & 20.8 & 35.4 & 32.3 & 10.9 \\
\hline TOTAL & 192 & & & . & \\
\hline MEAN PERCENTAGE & & 62.0 & 27.1 & 5.2 & 1.6 \\
\hline
\end{tabular}


not as important as their own happiness. However, the fact that a larger percentage of teenage young people answered in that way could possibly reflect a general trend on the part of single youth in those lower age brackets to seek independence from all types of authority and controls.

What effect did attendance at Adventist schools have on the attitude toward the importance of marriage within the church? Table 110 indicates a partial answer to that question. Although the percentage of those who said that they would never marry a non-member increased in proportion to the amount of Adventist education received, so also did the percentage of those who felt it was not important. This seems to indicate that there were at least two groups of youth among those raised in Adventist homes and educated entirely in Adventist schools. The obviously larger group accepted the teaching of the church in this respect and agreed with the importance of marriage within the church. The smaller percentage who were also raised in Adventist homes and had secured all of their education in Adventist schools, however, rebelled against this idea and were decidedly less inclined to go along with the principle of marriage only within the church. This would seem to indicate a real challenge to Adventist parents and educators and to all who would seek to increase the number of Adventist families.

Table 111 indicates somewhat of a change in attitudes from the days when the traditional Japanese family considered it "an 
TABLE 110

CORRELATION BETWEEN SINGLE ADVENTIST YOUTH'S OPINIONS AS TO THE

IMPORTANCE OF MARRYING A SEVENTH-DAY ADVENTIST CHURCH

MEMBER AND EXTENT OF EDUCATION IN ADVENTIST SCHOOLS

\begin{tabular}{|c|c|c|c|c|c|}
\hline \multirow{2}{*}{$\begin{array}{l}\text { Extent of } \\
\text { Education in } \\
\text { Adventist Schools }\end{array}$} & \multirow{2}{*}{$\begin{array}{c}\text { Total } \\
\text { Responses }\end{array}$} & \multicolumn{4}{|c|}{ Percentage of Total } \\
\hline & & $\begin{array}{l}\text { Very Important, } \\
\text { Would Never Marry } \\
\text { a Non-member. }\end{array}$ & $\begin{array}{l}\text { Very Important, } \\
\text { but Would not Rule } \\
\text { Out Marriage to a } \\
\text { Non-member. }\end{array}$ & $\begin{array}{l}\text { Not too Important, } \\
\text { Happiness is the } \\
\text { Most Important. }\end{array}$ & $\begin{array}{l}\text { Not Impor- } \\
\text { tant at } A 11 \text {. }\end{array}$ \\
\hline None at all & 86 & 64.0 & 26.7 & 3.5 & 1.2 \\
\hline $\begin{array}{l}\text { All education re- } \\
\text { ceived In Ad- } \\
\text { ventist schools }\end{array}$ & 12 & 75.0 & 8.3 & 16.7 & --- \\
\hline $\begin{array}{l}\text { Some of education } \\
\text { received in Ad- } \\
\text { ventist schools }\end{array}$ & 90 & 58.9 & 28.9 & 5.6 & 2.2 \\
\hline No answer & 4 & 50.0 & 50.0 & --- & -- \\
\hline TOTAL & 192 & & & & \\
\hline MEAN PERCENTAGE & & 62.0 & 27.1 & 5.2 & 1.6 \\
\hline
\end{tabular}


TABLE 111

SINGLE ADVENTIST YOUTH'S ATTITUDE TOWARD

MARRIAGE PLANS IF PARENTS STRONGLY OPPOSED PLANS

\begin{tabular}{|c|c|c|c|c|}
\hline \multirow{2}{*}{$\begin{array}{l}\text { Youth's Attitudes to } \\
\text { Parents' Opposition }\end{array}$} & \multicolumn{2}{|c|}{$\begin{array}{c}\text { Young } \\
\text { Men's Responses }\end{array}$} & \multicolumn{2}{|c|}{$\begin{array}{l}\text { Young } \\
\text { Women's Responses }\end{array}$} \\
\hline & Total & Percentage & Total & Percentage \\
\hline $\begin{array}{l}\text { Would respect parents' wishes } \\
\text { and cancel plans }\end{array}$ & 5 & 8.5 & 21 & 15.8 \\
\hline $\begin{array}{l}\text { As marriage is a personal } \\
\text { matter, would go on with } \\
\text { plans }\end{array}$ & 15 & 25.4 & 30 & 22.6 \\
\hline $\begin{array}{l}\text { It would depend on their } \\
\text { reasons for objecting }\end{array}$ & 37 & 62.7 & 65 & 48.9 \\
\hline Other & 1 & 1.7 & 5 & 3.8 \\
\hline No answer & 1 & 1.7 & 12 & 9.0 \\
\hline TOTAL & 59 & 100.0 & 133 & 100.1 \\
\hline
\end{tabular}

offense to parents and a disgrace to society, "I for a young person to marry without his parents" consent. Among Adventist youth 8.5 percent of the young men and 15.8 percent of the young women stated that they would respect their parents' wishes if they were strongly opposed and would cancel their marriage plans. A slightly larger percentage of young men than young women felt that since marriage was a personal matter they would go ahead with plans even though their parents strongly objected. How a similar question would be answered by

${ }^{1}$ Daigoro Goh, "Family. Relations in Japan," Transactions of the Japan Society, Vo1. II, 1892-1893, in Ray E. Baber, Youth Looks at Marriage and the Fanily (Tokyo: International Christian University, 1958), p. 48 . 
single Adventist youth in the United States or in some other Western society might indicate whether there still were some remnants of the traditional attitudes toward acquiescence of parental desires in this matter within Japanese Adventist culture.

Another question regarding marriage asked of Japanese Adventist youth was what they thought would happen to their marriage and their faith if they married someone who was not an Adventist church member. Table 112 records their responses. A larger percentage of young women than young men responded that they felt their faith would be weakened by such a marriage. Three times the percentage of young men as compared to young women said that even though they married someone who was not a church member they would eventually succed in influencing their spouse to become a member. A small percentage of both young men and women stated that they felt there would be no change in either their non-Adventist spouse's attitude toward the church or in their own Christian faith. When asked to comment on some other possible results of marriage to a non-member, the great majority said they thought there would be more conflict between husband and wife and less happiness in the home.

\section{Attitudes of Single Youth Toward the Wife Working Outside the Home}

Table 113 records the responses of single Adventist young people concerning their attitudes toward the wife working outside the home. By comparing these responses to those of the spouses of the Adventist homes as shown in table 96 , it can be seen that 
TABLE 112

\section{SINGLE ADVENTIST YOUTH'S OPINIONS AS TO THE \\ PROBABLE RESULTS OF MARRIAGE TO A} INON-MEMBER

\begin{tabular}{|c|c|c|c|c|}
\hline \multirow{2}{*}{$\begin{array}{l}\text { Results of Marriage } \\
\text { to a Non-member }\end{array}$} & \multicolumn{2}{|c|}{$\begin{array}{c}\text { Young } \\
\text { Men's Responses }\end{array}$} & \multicolumn{2}{|c|}{$\begin{array}{c}\text { Young } \\
\text { Women's Responses }\end{array}$} \\
\hline & Total & Percentage & Total & Percentage \\
\hline $\begin{array}{l}\text { Christian faith would weaken } \\
\text { but wouldn't leave the } \\
\text { church }\end{array}$ & 25 & 42.4 & 77 & 57.9 \\
\hline $\begin{array}{l}\text { Non-Adventist spouse would } \\
\text { join the church }\end{array}$ & 18 & 30.5 & 12 & 9.0 \\
\hline $\begin{array}{l}\text { Neither of the above but } \\
\text { would remain a faithful } \\
\text { church member }\end{array}$ & 1 & 1.7 & 5 & 3.8 \\
\hline Other results & 6 & 10.2 & 17 & 12.8 \\
\hline No answer & 9 & 15.3 & 22 & 16.5 \\
\hline TOTAL & 59 & 100.1 & 133 & 100.0 \\
\hline
\end{tabular}

between two and three times the percentage of single young people said they would never agree to the wife working outside the home. The percentage of respondents who said they would approve, if the husband and wife agreed, was less than half that of the married couples. This would seem to indicate that the youth were somewhat more idealistic or perhaps less realistic than were married couples with children. 
TABLE 113

SINGLE ADVENTIST YOUTH'S OPINIONS REGARDING WIFE WORKING OUTSIDE THE HOME

\begin{tabular}{|c|c|c|c|c|}
\hline \multirow{2}{*}{$\begin{array}{c}\text { Opinions Regarding } \\
\text { Wife Working }\end{array}$} & \multicolumn{2}{|c|}{ Young Men } & \multicolumn{2}{|c|}{ Young Women } \\
\hline & $\begin{array}{c}\text { Total } \\
\text { Responses }\end{array}$ & $\begin{array}{l}\text { Percentage } \\
\text { of Tota1 }\end{array}$ & $\begin{array}{c}\text { Total } \\
\text { Responses }\end{array}$ & $\begin{array}{l}\text { Percentage } \\
\text { of Total }\end{array}$ \\
\hline $\begin{array}{l}\text { Approve if husband } \\
\text { and wife agreed }\end{array}$ & 6 & 10.2 & 12 & 9.0 \\
\hline $\begin{array}{l}\text { Disapprove while child- } \\
\text { ren were small }\end{array}$ & 22 & 37.3 & 58 & 43.6 \\
\hline Never agree & 23 & 39.0 & 45 & 33.8 \\
\hline Other & 6 & 10.2 & 5 & 3.8 \\
\hline No answer & 2 & 3.4 & 13 & 9.8 \\
\hline TOTAL & 59 & 100.1 & 133 & 100.0 \\
\hline
\end{tabular}

Assisting the Youth of the Church to

Establish Christian Homes as

Viewed by Single Adventist

Youth

From the point of view of the single young people, just how successful have the pastors and other church leaders of the Seventhday Adventist church been in helping them find mates within the church? What suggestions did the youth have for their leaders that would increase the degree and effectiveness of that help? Responses to these questions are recorded in tables 114 through 117.

As seen in table 114 the percentage of the young women who felt that the church was doing practically nothing at all to help was 23.1 percent. This percentage was nearly twice that of the young men and perhaps indicates that the single young women have a 
TABLE 114

SINGLE ADVENTIST YOUTH'S OPINIONS AS TO HOW

MUCH THE CHURCH IS DOING TO HELP ITS

YOUNG PEOPLE FIND ADVENTIST MATES

\begin{tabular}{|c|c|c|c|c|}
\hline \multirow{2}{*}{$\begin{array}{l}\text { Degree of Help the } \\
\text { church is Giving } \\
\text { to find Adventist } \\
\text { Mates }\end{array}$} & \multicolumn{2}{|c|}{$\begin{array}{c}\text { Young } \\
\text { Men's Responses }\end{array}$} & \multicolumn{2}{|c|}{$\begin{array}{l}\text { Young } \\
\text { Women's Responses }\end{array}$} \\
\hline & Total & Percentage & Total & Percentage \\
\hline It is doing nothing & 7 & 11.9 & 31 & 23.3 \\
\hline $\begin{array}{l}\text { It is doing something, but } \\
\text { not enough }\end{array}$ & 23 & 39.0 & 46 & 34.6 \\
\hline $\begin{array}{l}\text { It is a personal matter and } \\
\text { the church cannot do } \\
\text { anything }\end{array}$ & 4 & 6.8 & 11 & 8.3 \\
\hline It is doing all it can & 14 & 23.7 & 17 & 12.8 \\
\hline No answer & 11 & 18.6 & 28 & 21.1 \\
\hline TOTAL & 59 & 100.0 & 133 & 100.1 \\
\hline
\end{tabular}

greater degree of concern in this problem. When the twenty-eight young women who seemed to exhibit a feeling of enryo or hesitation to seem critical of those in positions of authority were excluded and the percentages re-calculated, nearly 30 percent of the young women felt that their church leaders were doing nothing at all to help solve this problem. In addition to this large group, an even larger percentage felt that the church was helping to some extent but not nearly enough. Again, when this large percentage is recalculated to exclude those who did not answer this question, nearly 45 percent of the women felt that the church could and should do more. In other words, by far the majority of single Adventist 
youth, nearly 63 percent of the men and 75 percent of the women, felt that their church was doing little or nothing to help them establish Adventist homes. Certainly this should be a real challenge to church leaders.

Table 115 analyzes these responses according to the age of the respondent. Those in the thirty-one to thirty-five year age bracket were, perhaps not unexpectedly, the most critical of the degree of help the church was giving them. Not only did 33.3 percent of these older youth, the highest percentage of any age bracket, feel that the church was doing nothing at all, but only 4.8 percent of this age group, the lowest of any group, thought the church was doing all that it could to help. These figures if nothing else should help church leaders feel some of the anxiety and frustration these older youth, especially young women, feel.

Single youth were asked to express their opinion as to how they thought the church could be of more assistance in helping them find Christian mates. A choice of three suggestions was given. The degree of approval for each of these suggestions is seen in tiable 116 . The first suggestion was for pastors, teachers, other church leaders, and parents to take a more direct responsibility and a more positive approach in helping bring together potential Adventist marriage partners. Nearly one in four of those responding felt this was the best suggestion.

The second suggestion proposed that the church should arrange more religious and social activities so young people could get to know each other better. Of the young men, 54.4 percent 
TABLE 115

CORRELATION BETWEEN SINGLE ADVENTIST YOUTH'S OPINION AS TO HOW

MUCH THE CHURCH IS DOING TO HELP ITS YOUNG PEOPLE FIND

ADVENTIST MATES AND AGE OF THE YOUTH

\begin{tabular}{|c|c|c|c|c|c|}
\hline \multirow[b]{2}{*}{ Age in Years } & \multirow[b]{2}{*}{$\begin{array}{c}\text { Total } \\
\text { Responses }\end{array}$} & \multicolumn{4}{|c|}{ Percentage of Total } \\
\hline & & $\begin{array}{l}\text { It is Doing } \\
\text { Nothing. }\end{array}$ & $\begin{array}{l}\text { It is Doing Some- } \\
\text { thing, but not } \\
\text { Enough. }\end{array}$ & $\begin{array}{l}\text { It is a Personal } \\
\text { Matter, and the } \\
\text { Church Cannot do } \\
\text { Anything. }\end{array}$ & $\begin{array}{l}\text { It is Doing } \\
\text { All It Can. }\end{array}$ \\
\hline 20 years or under & 40 & 17.5 & 50.0 & 2.5 & 12.5 \\
\hline $21-25$ & 68 & 11.8 & 36.8 & 8.8 & 22.1 \\
\hline $26-30$ & 62 & 25.8 & 29.0 & 11.3 & 16.1 \\
\hline $31-35$ & 21 & 33.3 & 28.6 & 4.8 & 4.8 \\
\hline TOTAL & 191 & & & & \\
\hline MEAN PERCENTAGE & & 19.8 & 35.9 & 7.8 & 16.1 \\
\hline
\end{tabular}


favored this suggestion and nearly half of the young women, that is, 47.9 percent, felt an increase in social activities would be the ideal plan.

TABLE 116

RESPONSE OF SINGLE ADVENTIST YOUTH TO SUGGESTIONS AS TO HOW THE CHURCH CAN

HELP ITS YOUNG PEOPLE FIND ADVENTIST MATES

\begin{tabular}{|c|c|c|c|c|}
\hline \multirow{2}{*}{$\begin{array}{c}\text { Suggestions of Church's } \\
\text { Help Preferred by } \\
\text { Youth }\end{array}$} & \multicolumn{2}{|c|}{$\begin{array}{c}\text { Young } \\
\text { Men's Responses }\end{array}$} & \multicolumn{2}{|c|}{$\begin{array}{c}\text { Young } \\
\text { Women's Responses }\end{array}$} \\
\hline & Total & Percentage & Total & Percentage \\
\hline $\begin{array}{l}\text { Pastors, teachers, and parents } \\
\text { should take more responsi- } \\
\text { bility. }\end{array}$ & 17 & 24.3 & 44 & 26.8 \\
\hline $\begin{array}{l}\text { The church should make more } \\
\text { opportunities for social and } \\
\text { religious fellowship avail- } \\
\text { able. }\end{array}$ & 43 & $61: 4$ & 91 & 55.5 \\
\hline $\begin{array}{l}\text { The Japan Union Mission of } \\
\text { Seventh-day Adventists } \\
\text { should prepare a dating file } \\
\text { service to help Adventist } \\
\text { youth meet prospective mates. }\end{array}$ & 7 & 10.0 & 18 & 11.0 \\
\hline Other suggestions. & 3 & 4.3 & 11 & 6.7 \\
\hline TOTAL & 70 & 100.0 & 164 & 100.0 \\
\hline
\end{tabular}

The third suggestion offered was for church leadership in the Japan Union Mission to take the initiative in preparing a master dating file of Adventist youth which would help interested parties to meet and get acquainted with prospective mates. This suggestion may have seemed rather unusual and radical, as was indicated by the less than one of ten of both young men and women who favored it. 
Comments written on the questionnaire and made by some of the respondents in direct conversation would indicate that insufficient explanation given with this plan and how it could be helpful kept young people from favoring this third suggestion.

When the suggestions chosen by these Adventist youth was viewed from the perspective of the age of the respondent, it can be seen that younger respondents favored an increase in the number of church-sponsored socials and religious fellowship occasions (see table 117). The older youth showed more interest than the younger ones in some sort of dating-file service. The age of the respondent had little to do with the degree of support the young people gave for more direct responsibile help from church leaders, although there was a slightly greater percentage of the older youth approving this idea.

From these data it would seem that there was certainly a great deal of dissatisfaction on the part of single Adventist young persons concerning the degree of assistance being given them in meeting prospective marriage partners. Furthermore, many church pastors have expressed the opinion that a large percentage of the young women among their church membership who were inactive or who seemed to have completely backslidden had as a common denominator a difficulty in finding an Adventist mate.

Single Adventist youth are a vital part of the church. Their observations concerning the homes in which they were raised as well as their opinions and ideals relating to the homes they hope to establish provide valuable data that is helpful in forming a more 
TABLE 117

CORRELATION BETWEEN RESPONSE OF SINGLE ADVENTIST YOUTH TO

SUGGESTIONS AS TO HOW THE CHURCH CAN HELP ITS YOUNG PEOPLE FIND ADVENTIST MATES AND AGE OF YOUTH

\begin{tabular}{|c|c|c|c|c|c|}
\hline \multirow[b]{2}{*}{ Age in Years } & \multirow[b]{2}{*}{$\begin{array}{c}\text { Total } \\
\text { Responses }\end{array}$} & \multicolumn{4}{|c|}{ Percentage of Total } \\
\hline & & $\begin{array}{l}\text { Pastors, Teachers, } \\
\text { and Parents Should } \\
\text { take more Respons- } \\
\text { ibility. }\end{array}$ & $\begin{array}{l}\text { The church Should } \\
\text { make Available } \\
\text { more Opportunities } \\
\text { for Social and Re- } \\
\text { ligious Fellowship. }\end{array}$ & $\begin{array}{c}\text { The Japan Union Mis- } \\
\text { sion of SDA should } \\
\text { Prepare a Dating } \\
\text { File Service to } \\
\text { help SDA Youth Meet } \\
\text { Prospective Dates. }\end{array}$ & $\begin{array}{c}\text { Other } \\
\text { Suggestions }\end{array}$ \\
\hline 20 years or under & 40 & 22.6 & 52.8 & 5.7 & 5.7 \\
\hline $21-25$ & 68 & 21.5 & 55.9 & 5.4 & 5.4 \\
\hline $26-30$ & 62 & 23.4 & 48.9 & 12.8 & 5.3 \\
\hline $31-35$ & 21 & 25.0 & 28.6 & 17.0 & 3.6 \\
\hline TOTAL & 191 & & & & \\
\hline MEAN PERCENTAGE & & 22.7 & 49.8 & 9.3 & 5.2 \\
\hline
\end{tabular}


complete picture of the Adventist family in Japan. Those interested in strengthening the Adventist family would do well to sense some of the anxiety and frustration on the part of many of these single young Adventists. A careful study should be made using all the available data to help Adventist youth fulfill their expectations in building stable Adventist families. 


\section{CHAPTER XI}

\section{THE ROLE OF THE ADVENTIST CLERGY}

\section{IN FAMILY MINISTRY}

The local church pastor is unquestionably in as good a position as any one to understand the inner dynamics of the Adventist family and to know its problems and potentials. Not only does he minister publicly each week to the various members of the family, but from time to time throughout the entire spectrum of the lives of the members, he personally and repeatedly ministers by instructing, counseling, comforting, encouraging, rebuking, sharing, and rejoicing with the members individually. The measure of success he has in this area of his ministry depends on the genuineness of his spirituality, the length and quality of his experience, the completeness of his dedication, and the degree of his human warmth and understanding. It will also depend on the extent of the specialized training he has received in family ministry, his skills as a family counsellor, and his ability to come close to the family as a genuine friend.

This chapter records and analyzes briefly the responses of Seventh-day Adventist clergymen in Japan concerning their ministry to the family. The survey instrument consisted of fourteen questions and was sent to the 108 active and retired ministers listed by the headquarters office of the Japan Union 
Mission of Seventh-day Adventists in Yokohama. Responses were received from ninety-nine, or 92 percent, of the ministers.

\section{Selected Information Concerning Adventist Ministers in Japan}

Table 118 gives a summary of the responses of these ministers concerning certain selected characteristics. The age of the ministers responding indicates that a larger number were in the middle-age range, from thirty-one to fifty-five years of age, than in the older or younger age brackets. The ministers who were fifty-six years of age and over no doubt represented those who had recieved their ministerial training and their call to the ministry before World War II. The decline in the number of ministers in the two lower age groups seems to represent a decrease in the number of younger men entering the ministry in the Adventist church during recent years as compared to the first two decades following the war.

Two basic categories of ministers among Seventh-day Adventists were those with credentials who were ordained and those with ministerial licenses who were unordained. Nearly 77 percent of all Seventh-day Adventist ministers completing the survey instrument were ordained. The licensed ministers were either younger men who were gaining experience prior to ordination or ministers who were engaged in a line of work other than pastoral or evangelistic and thus not specifically in line for ordination.

The clergy who responded to the questionnaire were employed in various lines of ministry. The largest number, nearly seven 
TABLE 118

SELECTED CHARACTERISTICS OF SEVENTH-DAY ADVENTIST MINISTERS

\begin{tabular}{|c|c|c|c|}
\hline & Categories of Respondents & $\begin{array}{l}\text { Number of } \\
\text { Responses }\end{array}$ & $\begin{array}{l}\text { Percentage } \\
\text { of total* }\end{array}$ \\
\hline Age & $\begin{array}{l}25 \text { years or under } \\
26-30 \\
31-35 \\
36-40 \\
41-45 \\
46-55 \\
56-65 \\
66 \text { years or over }\end{array}$ & $\begin{array}{r}3 \\
9 \\
20 \\
12 \\
19 \\
19 \\
8 \\
9\end{array}$ & $\begin{array}{r}3.0 \\
9.1 \\
20.2 \\
12.1 \\
19.2 \\
19.2 \\
8.1 \\
9.1\end{array}$ \\
\hline $\begin{array}{l}\text { Type of } \\
\text { license }\end{array}$ & $\begin{array}{l}\text { Ministerial license-- } \\
\quad \text { (unordained) } \\
\text { Ministerial credentials-- } \\
\quad \text { (ordained) }\end{array}$ & $\begin{array}{l}22 \\
76\end{array}$ & $\begin{array}{l}22.2 \\
76.0\end{array}$ \\
\hline $\begin{array}{l}\text { Type of } \\
\text { employment }\end{array}$ & $\begin{array}{l}\text { Church pastor } \\
\text { Departmental secretary } \\
\text { Administrative officer } \\
\text { Teacher } \\
\text { Institution related-- } \\
\text { chaplain, etc. } \\
\text { Retired }\end{array}$ & $\begin{array}{r}68 \\
7 \\
6 \\
4 \\
\\
6 \\
8\end{array}$ & $\begin{array}{r}68.7 \\
7.1 \\
6.1 \\
4.0 \\
6.1 \\
8.1\end{array}$ \\
\hline $\begin{array}{l}\text { Length of } \\
\text { ministry }\end{array}$ & $\begin{array}{l}2 \text { years or less } \\
3-5 \text { years } \\
6-10 \text { years } \\
11-20 \text { years } \\
21-35 \text { years } \\
36 \text { years or more }\end{array}$ & $\begin{array}{r}6 \\
20 \\
24 \\
28 \\
15 \\
6\end{array}$ & $\begin{array}{r}6.1 \\
20.2 \\
24.2 \\
28.3 \\
15.2 \\
6.1\end{array}$ \\
\hline TOTAL RESP & & 99 & \\
\hline
\end{tabular}

Note: The total percentage within each category equals 100 percent of the ministers who responded. The figures have been rounded off to the nearest. 1 of one percent. 
out of ten, were pastoring one or more local churches. Although eight of them were retired there were some who were still helping in some form of part-time ministry. The remainder of the minsters surveyed were serving as administrators, departmental secretaries, teachers, or in a medical, educational, healthfood, or other denominational institution. Some of the ministers were carrying several types of responsibility, such as pastoring a local church and at the same time teaching, assisting in some departmental promotion activity of the Japan Union Mission, or some other work. As to length of service, about half of them had had eleven or more years of experience in the ministry.

\section{Specialized Training and Education for Family Ministry}

Table 119 records some areas in which the clergyman had had some training for family ministry. Table 120 indicates the degree of his interest in self-education in these fields as evidenced by the books he had read. A more specific and meaningful investigation perhaps should be undertaken to study the extent of preparation the ministers have received in the areas of psychology, general counseling, sex education, and marital counseling.

As table 119 indicates, about one out of three of the ministers had had at least a basic course in psychology and nearly half an introductory course in counseling. Those who had specific training in family counseling and marital problems were considerably fewer. Thirteen stated they had had some training in family counseling and less than half that number indicated that they had training in assisting with sex-related marital problems. 
TABLE 119

FAMILY-MINISTRY-RELATED TRAINING OF SEVENTH-DAY ADVENTIST MINISTERS

\begin{tabular}{lcc}
\hline $\begin{array}{c}\text { Family-related Training of } \\
\text { Adventist Ministers }\end{array}$ & $\begin{array}{c}\text { Total } \\
\text { Responses }\end{array}$ & $\begin{array}{c}\text { Percentage } \\
\text { of Total }\end{array}$ \\
\hline In psychology & 50 & 32.3 \\
In general counseling & 70 & 45.2 \\
In marriage or family counseling & 13 & 8.4 \\
In sex education & 6 & 3.9 \\
No answer & 16 & 10.3 \\
\hline TOTAL & 155 & 100.1 \\
\hline
\end{tabular}

TABLE 120

CORRELATION BETWEEN THE AMOUNT OF READING IN THE AREAS OF MARRIAGE COUNSELING AND FAMILY RELATIONSHIPS DURING THE PAST TWELVE MONTHS AND THE AGE OF THE MINISTER

\begin{tabular}{|c|c|c|c|c|}
\hline \multirow{2}{*}{ Age by Years } & \multirow{2}{*}{$\begin{array}{c}\text { Total } \\
\text { Responses }\end{array}$} & \multicolumn{3}{|c|}{ Percentage of Total } \\
\hline & & None & $\begin{array}{c}1-4 \\
\text { Volumes }\end{array}$ & $\begin{array}{l}5 \text { or ore } \\
\text { Volumes }\end{array}$ \\
\hline 25 years or under & 3 & 66.7 & 33.3 & --- \\
\hline $26-30$ & 9 & 22.2 & 55.6 & 22.2 \\
\hline $31-35$ & 20 & 30.0 & 60.0 & $-\infty-\infty$ \\
\hline $36-40$ & 12 & 50.00 & 41.7 & 8.3 \\
\hline $41-45$ & 19 & 5.3 & 84.2 & 5.3 \\
\hline $46-55$ & 19 & 26.3 & 47.4 & 21.1 \\
\hline $56-65$ & 8 & 25.0 & 75.0 & $-\infty$ \\
\hline 66 years or over & 9 & 55.6 & 11.1 & 11.1 \\
\hline TOTAL & 99 & & & \\
\hline MEAN PERCENTAGE & & 29.3 & 55.6 & 9.1 \\
\hline
\end{tabular}


To what extent these clergymen were attempting to further their training and skills in family ministry can be seen somewhat by noticing the amount of reading they do in the field. Table 120 shows that nearly 30 percent had read nothing on family ministry during the past year, and that 9.1 percent had read rather widely in the area. Slightly more than half, that is 55.6 percent, had done a little reading in this field. Ministers in the youngest and oldest age brackets reported the least reading; those in the forty-one to forty-five year bracket were most active in doing at least some reading in the area of family counseling and family ministry.

\section{Extent of Sermons and Talks Concerning} the Family by the Adventist Clergy

Table 121 contains a composite of five computer print-outs recording the answers of Adventist ministers as to what extent they had presented public sermons, lectures, or talks on various familyrelated topics. It indicates which areas of family ministry were being emphasized and which were being neglected.

The largest percentage, 72.7 percent, presented general messages on the Christian home. Nearly as many, 70.6 percent, reported they had given talks and sermons on some aspect of child. training. A little over half, 56.6 percent, stated that during the past twelve months they had given talks on the importance of family worship. The smallest percentage, 42.5 percent, said they had dealt with husband-and-wife relationships in a sermon or talk. 
TABLE 121

SERMONS AND TALKS PRESENTED ON FAMILY-RELATED TOPICS DURING THE PAST TWELVE MONTHS BY

SEVENTH-DAY ADVENTIST MINISTERS

\begin{tabular}{|c|c|c|c|c|c|}
\hline \multirow{2}{*}{$\begin{array}{l}\text { Types of } \\
\text { Sermons } \\
\text { given by } \\
\text { Ministers }\end{array}$} & \multirow{2}{*}{$\begin{array}{c}\text { Total } \\
\text { Responses }\end{array}$} & \multicolumn{4}{|c|}{ Percentage of Total } \\
\hline & & $\begin{array}{c}\text { None } \\
\text { Presented }\end{array}$ & $\begin{array}{c}1-4 \\
\text { presented }\end{array}$ & $\begin{array}{l}5 \text { or ore } \\
\text { Persented }\end{array}$ & $\begin{array}{c}\text { No } \\
\text { Answer }\end{array}$ \\
\hline $\begin{array}{l}\text { On the Christian } \\
\text { home in general }\end{array}$ & 99 & 13.1 & 62.6 & 10.1 & 14.1 \\
\hline $\begin{array}{l}\text { On husband and } \\
\text { wife relation- } \\
\text { ship }\end{array}$ & 99 & 20.2 & 35.4 & 7.1 & 37.4 \\
\hline On child training & 99 & 10.1 & 60.6 & 10.1 & 19.1 \\
\hline On family worship & 99 & 18.2 & 51.5 & 5.1 & 25.3 \\
\hline $\begin{array}{l}\text { On other family } \\
\text { related topics }\end{array}$ & 99 & 12.1 & 41.4 & 13.1 & 33.3 \\
\hline
\end{tabular}

\section{Family Related Counseling by Adventist Ministers}

Three questions in the survey instrument designed for the ministers dealt with what type and to what extent family counseling was practiced by the Adventist clergy in Japan. One question concerned the amount of pre-marriage counseling given to young couples. The responses to this question were limited to ordained ministers only and are recorded in table 122. Another question regarded the degree of marriage counseling Adventist ministers gave to husbands and wives. The responses to this question are noted in table 123. A third question asked how frequently ministers were involved in child-related counseling, either with the parent or with the child. Table 124 tabulates their answers. 
TABLE 122

DEGREE OF PRE-MARRIAGE COUNSELING OF COUPLES BY SEVENTH-DAY ADVENTIST ORDAINED MINISTERS

\begin{tabular}{lcc}
\hline $\begin{array}{c}\text { Degree of Pre-marriage Counseling } \\
\text { by Adventist Ministers }\end{array}$ & $\begin{array}{c}\text { Total } \\
\text { Responses }\end{array}$ & $\begin{array}{c}\text { Percentage } \\
\text { of Total }\end{array}$ \\
\hline $\begin{array}{l}\text { Never counsel the couple before } \\
\text { the wedding }\end{array}$ & 19 & 25.0 \\
$\begin{array}{l}\text { Sometimes counsel the couple } \\
\text { before the wedding }\end{array}$ & 48 & 63.2 \\
$\begin{array}{l}\text { Always counsel the couple } \\
\text { before the wedding }\end{array}$ & 6 & 7.9 \\
$\begin{array}{l}\text { No answer } \\
\text { TOTAL }\end{array}$ & 3 & 3.9 \\
\hline
\end{tabular}

TABLE 123

DEGREE OF MARRIAGE COUNSELING BY

SEVENTH-DAY ADVENTIST MINISTERS

\begin{tabular}{lcc}
\hline $\begin{array}{c}\text { Degree of Marriage } \\
\text { Counseling }\end{array}$ & $\begin{array}{c}\text { Total } \\
\text { Responses }\end{array}$ & $\begin{array}{c}\text { Percentage } \\
\text { of Total }\end{array}$ \\
\hline None at all & 29 & 29.3 \\
A little & 60 & 60.6 \\
Quite a lot & 5 & 5.1 \\
No answer & 5 & 5.1 \\
\hline TOTAL & 99 & 100.1 \\
\hline
\end{tabular}


TABLE 124

DEGREE OF CHILD-RELATED COUNSELING BY

SEVENTH-DAY ADVENTIST MINISTERS

\begin{tabular}{lcc}
\hline $\begin{array}{c}\text { Degree of Child-related } \\
\text { Counseling }\end{array}$ & $\begin{array}{c}\text { Total } \\
\text { Responses }\end{array}$ & $\begin{array}{c}\text { Percentage } \\
\text { of Total }\end{array}$ \\
\hline None at all & 12 & 12.1 \\
A little & 63 & 63.6 \\
Quite a lot & 20 & 20.2 \\
No answer & 4 & 4.0 \\
\hline TOTAL & 99 & 99.9 \\
\hline
\end{tabular}

From a study of these three tables it seems that Adventist ministers do more counseling with children or about children than they do in marital counseling. Nearly 30 percent stated they did no marital counseling of any kind. Only 5 percent were doing marriage counseling to any great extent. This means that either Adventist family spouses got along so well they felt no need for counseling, that husbands and wives who did need help were going elsewhere to get that help, or they were not obtaining any help at all.

Table 122 seems to indicate that only a few ministers were regularly and consistently counseling those couples who came to them before marriage. Although the majority of the ministers, that is 63.2 percent, were giving this kind of counsel from time to time, one out of four never did any kind of pre-marriage counseling and less than one out of ten, 7.9 percent, counseled the couple before the wedding ceremony. 
Major Problem Areas in the Family as Viewed by Adventist Ministers

What did ministers who know the various family members consider to be the major problems in the Adventist family? Each minister was asked to check the three areas that, from his point of view, caused the major Adventist family problems. Table 125 records the answers according to rank from the greatest to the least. Responses to a similar question asked of husbands and wives of Adventist families can be noted and compared in tiables 82 and 83. Although the lists are not identical, a comparison is helpful in gaining a better understanding of problem areas. According to the ministers surveyed, emotionally related problems (insecurity, immaturity, or instability on the part of one or both spouses), were the major causes of marital friction and problem. This was followed closely by financial problems, Sabbath problems, and problems related to child training and discipline.

A comparison of major problem areas as perceived by ministers and the couples themselves would seem to suggest that the ministers were not always working on the most troublesome problems. Real problems were not so much external as internal. Counseling that would help husbands and wives solve their inner conflicts, that would help them to establish their relationship to the Lord more firmly, and that would help settle their personality differences, would enable them to mature as individuals and grow as Christians. Not only. would the degree of understanding and harmony between husband and wives increase, but they would also be better equipped to help solve the outer and obvious problems that come with being a Christian in a sinful world. 
TABLE 125

MAJOR PROBLEM AREAS OF ADVENTIST FAMILIES AS

SEEN BY SEVENTH-DAY ADVENTIST MINISTERS

\begin{tabular}{|c|c|c|c|}
\hline $\begin{array}{l}\text { Major Problem Areas of } \\
\text { Adventist Families }\end{array}$ & $\begin{array}{l}\text { Total } \\
\text { Responses }\end{array}$ & Rank & $\begin{array}{l}\text { Percentage } \\
\text { of Tota1 }\end{array}$ \\
\hline $\begin{array}{l}\text { Emotionally related problems, in- } \\
\text { security, immaturity, instability }\end{array}$ & 45 & 1 & 16.2 \\
\hline Financial problems & 41 & 2 & 14.8 \\
\hline Sabbath-related problems & 38 & 3.5 & 13.7 \\
\hline $\begin{array}{l}\text { Child-training and discipline } \\
\text { problems }\end{array}$ & 38 & 3.5 & 13.7 \\
\hline Job-related problems & 33 & 5 & 11.9 \\
\hline $\begin{array}{l}\text { Problems concerning maintenance } \\
\text { of church standards }\end{array}$ & 28 & 6 & 10.1 \\
\hline Health-related problems & 27 & 7 & 9.8 \\
\hline Infidelity & 13 & 8 & 4.7 \\
\hline Constant quarreling and fighting & 9 & 9 & 3.2 \\
\hline Other problems & 5 & 10 & 1.8 \\
\hline TOTAL & 277 & & 99.9 \\
\hline
\end{tabular}

Seeking the Understanding and Approval of . Close Family Members Before Baptizing a Candidate

In seeking to win converts to Christ and the church, a minister is often tempted to ignore the feeling of the baptismal candidate's inmediate family. Making a decision to accept Christ and join the church is a very personal matter. And yet it is also a matter that deeply affects other members of the family. What should be the attitude and practice of the minister toward those 
who show an interest in Christianity? What should be his attitude toward those family members who strongly oppose the baptism? Does the minister always seek the understanding and approval of the candidate's family before conducting the baptismal service? The responses of the ministers to this question are recorded in table 126.

TABLE 126

THE EXTENT TO WHICH SEVENTH-DAY ADVENTIST MINISTERS SOUGHT THE UNDERSTANDING AND APPROVAL OF CLOSE RELATIVES OR SPOUSE OF THE CANDIDATE BEFORE BAPTISM

\begin{tabular}{lcc}
\hline $\begin{array}{c}\text { The Degree to which Family } \\
\text { Approval is Sought }\end{array}$ & $\begin{array}{c}\text { Total } \\
\text { Responses }\end{array}$ & $\begin{array}{c}\text { Percentage } \\
\text { of Total }\end{array}$ \\
\hline $\begin{array}{l}\text { Never seek understanding and } \\
\text { approval before baptism }\end{array}$ & 9 & 9.1 \\
$\begin{array}{l}\text { Sometimes seek understanding and } \\
\text { approval before baptism }\end{array}$ & 56 & 56.6 \\
$\begin{array}{l}\text { Always seek understanding and } \\
\text { approval before baptism }\end{array}$ & 25 & 25.3 \\
$\begin{array}{l}\text { No answer } \\
\text { TOTAL }\end{array}$ & 9 & 9.1 \\
\hline
\end{tabular}

About one out of ten of the Adventist ministers surveyed had never tried to seek this understanding and approval of close family members before baptism. The majority, 56.6 percent, stated that they had sometimes made such an attempt although it was not a regular practice with them. One out of four stated that they always made this attempt before baptizing a candidate. 
It would seem from a study of this table that much more could be done to try to understand the feelings of frustration, anger, and bitterness on the part of close family members of the baptismal candidate. Perhaps one way of increasing the number of united Adventist families would be to go a bit slowly in encouraging an interested person to go against the wishes of his or her family and, if necessary, to temporarily postpone the plans for baptism until a stronger effort has been made to understand the non-Christian family's position and to secure their interest in the truth also. This is especially true in Japan with its long history of family solidarity and group responsibility.

\section{Expression of Interest on the Part of Adventist Ministers for Further Training for Family Ministry}

The Seventh-day Adventist ministers were asked a question regarding their interest in further training for family ministry and evangelism. Table 127 summarizes their responses.

Two percent expressed no desire at all, and about 7 percent gave no answer at a11. The remainder, 91 percent, expressed some interest in learning more about this area of their ministry. Three out of ten indicated that they had a great desire to study more about family ministry. Six out of ten stated that they would be interested if there were a good opportunity and they were able to arrange for such training.

The expression of interest in further study in this area of ministry was rather evenly distributed in all age levels of ministers. There seemed to be a slightly greater interest in this training 
among those in the earlier years of their ministry than in the later years. It would seem that Adventist ministers as a whole not only felt the need of more training but also looked forward to getting more training.

The Seventh-day Adventist clergy holds a key role in any attempt to strengthen the family. By their position as pastors ministering to the various members of both united and divided families, they continually have opportunities to gain insights into the dynamics and problems of the family. They can also better understand the potentials of a genuinely happy, stable, and active . Christian family. The Adventist ministers surveyed seemed willing and eager to assume a larger role in this area of ministry. 
TABLE 127

DESIRE EXPRESSED BY SEVENTH-DAY ADVENTIST MINISTERS FOR FURTHER TRAINING IN FAMILY MINISTRY

\begin{tabular}{|c|c|c|c|c|c|}
\hline \multirow{2}{*}{ Age by Years } & \multirow{2}{*}{$\begin{array}{c}\text { Total } \\
\text { Responses }\end{array}$} & \multicolumn{4}{|c|}{ Percentage of Total } \\
\hline & & $\begin{array}{c}\text { Don't Feel the } \\
\text { Need for this } \\
\text { Training }\end{array}$ & $\begin{array}{c}\text { Would like the } \\
\text { Opportunity } \\
\text { for Further } \\
\text { Training }\end{array}$ & $\begin{array}{l}\text { Greatly Desire } \\
\text { this Training }\end{array}$ & $\begin{array}{c}\text { No } \\
\text { Answer }\end{array}$ \\
\hline 25 years or under & 3 & ---- & 66.7 & 33.3 & $\cdots$ \\
\hline $26-30$ & 9 & --- & 44.4 & 44.4 & 11.1 \\
\hline $31-35$ & 20 & ---- & 50.0 & 40.0 & 10.0 \\
\hline $36-40$ & 12 & --- & 83.3 & 16.7 & --- \\
\hline $41-45$ & 19 & 10.5 & 63.2 & 26.3 & --- \\
\hline $46-55$ & 19 & $-\cdots$ & 57.9 & 36.8 & 19.2 \\
\hline $56-65$ & 8 & --- & 75.0 & 25.0 & ---- \\
\hline 66 years or over & 9 & $-\cdots$ & 55.6 & 11.1 & 33.3 \\
\hline TOTAL & 99 & & & & \\
\hline MEAN PERCENTAGE & & 2.0 & 60.6 & 30.3 & 7.1 \\
\hline
\end{tabular}


CHAPTER XII

\section{RESPONDENTS' SUGGESTIONS FOR STRENGTHENING \\ THE ADVENTIST FAMILY FOR FAMILY}

\section{EVANGELISM}

One of the purposes of this descriptive study of the Adventist family in Japan has been to learn how to utilize this deeper understanding of the family to strengthen and use it for family evangelism. This chapter records the suggestions made by respondents of the various survey instruments regarding family strengthening and family evangelism.

In the Seventh-day Adventist Family Survey the following questions which asked for suggestions were listed under section $E$, "Dynamics of the Family."

"9. What suggestions do you have that will help the Adventist family reach non-Adventist relatives, friends, and neighbors?"

"15. In the space below write your suggestions as to how best to win non-Adventist spouses to Christ." (This question was limited to spouses of divided families only.)

In the survey instrument sent to Adventist ministers, the following question asking for suggestions was included.

"13. It is very important that husbands and wives are united in church membership. In the space below write your 
suggestions for developing and strengthening united Adventist families and for using them to reach non-Adventist relatives and neighbors for Christ."

The suggestions written in answer to the above three questions have been collected, edited and arranged without comment. Although there is some duplication of thought, these suggestions indicate a deep concern for the family and should be a valuable source of ideas for anyone seeking a key to successful family evangelism in Japan.

Importance of Christian Attitudes and Example

1. Reflect the example of Christ more consistently in daily life.

2. Be a cheerful Christian; keep a smile on the face; give a good impression of Christianity.

3. Testify of the blessings and happiness experienced as a Christian.

4. Discard the feeling of being "God's elite," of being better than others.

5. Be consistent in all things, living up to Bible principles and teachings concerning Sabbath keeping, healthful living, honesty, and so forth.

6. Never speak ill of others.

7. Pray for non-Christian friends and neighbors.

8. Be faithful in personal devotions and Bible study and in this way witness to the power of God's Word. 
Importance of the Christian Home

9. Give greater attention to helping Adventist families realize the importance and potential of the home as an evangelistic agency.

10. Strengthen the practice of regular family worship and use it as an opportunity to instill Biblical principles and teaching.

11. Teach clearly and practically the importance of happy and harmonious relationships between husband and wife as a foundation for a happy home.

12. Emphasize the importance of a happy, healthy, and united family as an example that will attract others to the church.

13. As the wife is often the most responsive to the gospel appeal, seek to win her first and then work through her to win her husband and children.

14. If at all possible attempt to study the gospel message with the husband and wife together and thus bring them into the church as a united family.

15. Make the Christian home an evangelistic center for youth fellowships, socials, Bible studies, children's meetings, and community gatherings.

Christian Fellowship and Marriage

16. Plan social events at the church for the entire family and invite other families and non-member relatives; family night once a week or once a month, for instance. 
17. Invite non-members of the family to church functions, such as Sabbath School, church service, and special events, where they can partake of the spiritual fellowship together with church members.

18. Invite non-Adventist young people to homes of members to see and participate in the joy and beauty of the Christian home.

19. Work through youth to reach other youth, hold youth rallies and socials to help form Christian friendships and increase dating opportunity.

20. Encourage and help Adventist youth to marry church members.

21. Insist on at least three pre-marriage counseling sessions before the wedding to help Adventist couples establish sound Christian homes.

22. Use the wedding of non-members in Adventist churches as an opportunity to teach them concerning true happiness in marriage.

\section{The Minister's Role in Family Training and Education}

23. Encourage ministers to sense more deeply the importance of the Christian home and their responsibility to work for nonChristian family members.

24. Encourage ministers to give more attention to educating and training the members concerning the true meaning of the gospel message as it applies to daily living.

25. Be sure the interested person or baptismal candidate is carefully instructed before baptism and has an opportunity to 
find solutions to his or her personal problems, including relationships with his or her family.

26. Teach more clearly the Adventist Christian way of life as it deals with every-day relationships and problems.

27. Carefully study the counsel and instruction concerning the family that is found in the writings of the Spirit of Prophecy and give specific instruction based on it to church members.

28. Conduct parent-education programs in the church and invite specialists to help with the instruction.

29. Provide training and orientation programs for new Adventist families and help them to feel accepted by the church and to learn from the shared experiences of happily married couples.

30. Hold seminars for those who are the only Christians in their families to encourage them and to help them develop ideas as to how to win their non-Christian family members to Christ. A witnessing team that stresses real life experiences might be effective.

31. Give instruction and counsel to married women in the church and encourage them to support the leadership of their husbands, even though the husbands may not be members. Give similar instruction to Christian husbands and encourage them to assume their God-ordained leadership role in the family.

32. Encourage ministers to seek to establish close fellowship ties with church members and with seekers after truth.

33. Make the minister's family a demonstration of the power of Christianity to change lives and to make families happy and united. 
34. Work with other church leaders to prepare articles, pamphlets, and books that deal with specific problems such as child training, husband and wife relationships, sex and marriage, dating, and other subjects that foster an ideal Christian home.

35. Encourage Adventist youth and interested seekers after truth to attend Seventh-day Adventist schools.

36. Help and encourage church members to establish representative Adventist-owned businesses where youths could find employment and keep the Sabbath.

37. Make a greater effort to assist Adventist youth to find employment where they can keep the Sabbath.

38. Arrange for more opportunities for ministers to get together to exchange ideas and suggestions concerning problems and challenges of ministering to families and family evangelism.

\section{Influencing the Local Community}

39. Remember the teaching of Christ that His followers should be the salt of the earth and become the Christian influence they should be wherever they are in society.

40. Develop friendships with non-Christian families, try to understand the problems and feelings of these families, and show them love and sympathy.

41. Be a loving neighbor, offer advice and kindly help whenever possible.

42. As far as possible, become one with the community with its interests and concerns. 
43. When talent and circumstances permit, become a community leader.

44. Increase the degree of communication between members and non-members in the neighborhood and community.

45. Encourage ministers in particular to develop closer contacts with community leaders and to offer their services.

46. Encourage friends and neighbors who need medical help to go to an Adventist medical institution.

47. Promote and conduct more community-service-oriented programs, such as cooking schools, "Five-Day-Stop-Smoking" programs, and medical clinics.

48. Promote temperance and healthful-living programs and demonstrate health foods produced by the church-operated health food industry.

49. Do what can be done on a personal basis to give help and encouragement to the sick and needy.

\section{Direct Family Evangelism}

50. Conduct small family-centered evangelistic meetings outside the church.

51. Invite non-Adventist family members and relatives to attend special services at the church.

52. Enroll non-Adventist family nembers and relatives in Bible correspondence courses and help them to understand the lessons.

53. Write letters of encouragement to non-member relatives, tell them of your own happiness as a Christian and, from time to time, send them appropriate religious books and magazines. 
54. Lend religious tapes of music and sermons to relatives, especially the elderly and "shut-ins."

55. Give Bible studies in the home and invite neighboring families.

56. Encourage several families to join together in areas where there is no Adventist church and to invite non-Adventist families to meet with them. (This may give rise to the establishment of a new church.)

57. Carefully train the children, for well-trained children of Adventist families make good evangelists.

58. Work through Adventist youth and children to influence the parents.

59. Have some type of kamban or poster to place in front of Adventist homes that would identify them as places where help can be found and thus make each home an evangelistic center.

60. Invite neighbors to a meal and introduce them to the warmth and peace of a Christian family.

Winning a Non-Adventist Spouse to Christ and the Church

61. Continually seek to make close contact with the nonmember spouse and include him or her in close, warm fellowship.

62. Invite the non-member to special church services and functions.

63. Make it as easy as possible for the non-member spouse to accept the warmth and fellowship of the church group. 
64. Listen carefully to the ideas, thoughts, and doubts of the non-member without forcing your religious beliefs on him. Show an interest in the non-member's religious beliefs.

65. Church members with similar interests and hobbies should attempt to draw close to the non-member in a social way at first to develop his or her friendship.

66. The pastor should make it his duty to get to know the non-member intimately as a friend on other than religious occasions.

67. Encourage the non-member to listen to the churchsponsored religious broadcasts and to enroll in the Bible Correspondence Course.

68. The character and life of the one closest to the nonmember is very important. A consistent witness to the joy and changed life found in his religion is hard to resist.

69. Teach the wife of a non-Adventist husband to pattern her daily life after the counsel of the Scriptures, to live meekly and lovingly with him, and to follow his guidance and leadership as far as possible.

70. Always show unfailing, Christ-like love, and try to understand the feelings of the one who opposes you in your faith.

71. Avoid a "holier than thou" attitude; instead show the spirit of a learner. Seek to learn together with your non-member spouse, God's will as taught in the Bible.

72. Earnestly and continually pray for your spouse. God will find a way to answer your prayers. 


\section{Appealing to Men}

73. Direct the advertising and messages of evangelistic meetings more to the feelings and needs of men.

74. Provide a more intellectually stimulating message. When the pastor or evangelist gives evidence of lack of education and logic, he loses his ability to appeal to most men.

75. Show more common sense practicality in regard to society and its problems.

76. Set up a study group in the Church to investigate various ways to attract more marriageable aged young men to the church.

77. Carefully and logically approach the educated non-member husband in an attempt to help him understand the real meaning of the gospel. Failure to comprehend the essence of its message and its relationship to man in modern society is often the cause of his opposition.

78. Help and encourage the non-member husband to step out in faith. Many of these men believe deep in their hearts but feel that they must sacrifice their own religious and eternal interests in order to support their families in an ungodly society.

As recorded in this chapter, the suggestions from the respondents to the various survey instruments concerning family evangelism represent a rather wide spectrum of Adventist believers in Japan. Comments and suggestions came from young and old, single and married, ministers and laymembers and indicate a genuine and wide-spread interest in and concern for the Adventist family and its potential for evangelism. Many of the suggestions indicate 
an awareness of real but often hidden issues. By no means should the value of these insights and approaches be overlooked in translating the findings of this study into a practical program to strengthen the Adventist family and to increase its effectiveness in evangelism. 
CHAPTER XIII

SUMMARY, INSIGHTS, AND RECOMMENDATIONS

The descriptive'study undertaken in these chapters had as its objective the uncovering of the historical and cultural roots related to the Seventh-day Adventist family in Japan and the obtaining of a clearer understanding of the dynamics that are operating in the Japanese Adventist family today. This has been attempted within the overall framework of Christ's commission to His followers to go into all the world with the gospel message and to make disciples of all men. Japan has long presented a special challenge to the Christian church as it has sought to fulfill Christ's commission. It has at times seemed to Christians and non-Christians alike that Japan was an inhospitable swamp that inhibited the growth of the Christian message.

One of the keys for unlocking the enigma that faces the Church in Japan today can be found in a family-centered program of evangelism. This key is particularly important in a strongly familyoriented culture such as is found in Japan. While Japanese culture often seems inhospitable to the growth of Christianity, to many Japanese Christianity appears to be a foreign religion which is hostile to their habits, priorities, sense of values, traditional way of life, and their very sense of being Japanese. To many, becoming a Christian somehow means becoming less Japanese. To . 
succeed in overcoming this barrier, Christianity must not only preach the gospel message with conviction and power but it must also pause to 1 isten, to empathize with the feelings and longings of the Japanese people, and to discover the truths that have for centuries been cherished by her people and have been revealed particularly through Japanese culture. As Takaaki Aikawa, one time president of Kanto Gakuin, declared, "Christianity could have had far greater influence (in Japan) had it been introduced with a deep concern for the family, according to the Oriental tradition." 1

\section{Summary of Findings Concerning the Adventist Family in Japan}

The first united Adventist family in Japan began in the early part of the twentieth century. By the end of 1975 there were 935 Adventist families. The Adventist family in Japan is both Christian and Japanese, or perhaps it would be more correct to say that it is first Japanese and then Christian. The cultural stream that has produced the traditional Japanese family has come in contact with a Christianity that has been mixed with Western thinking and culture. In order to better understand the Adventist family and to become more skillful in reaching through it to make meaningful contacts to others within the society and culture of Japan, a twofold approach has been taken. First of all, a review of the literature dealing with the cultural origins, evolution, and changes that have taken place in the family was undertaken. This was a preIude to an investigation of the family by means of various survey instruments.

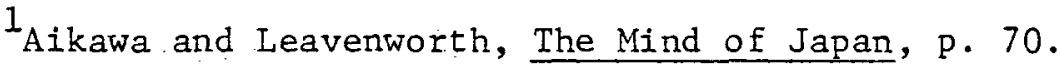


The traditional Japanese family was largely formed during the feudal period of Japanese history known as the Tokugawa Era (1603-1868) and, with minor changes, this traditional form has continued through several centuries. During the Meiji Era (1868-1912) which followed, some minor changes continued to take place, but most of the characteristics of the traditional family were fixed even more firmly. Since that time the pace of change has greatly accelerated. This is especially true in the decades since World War II.

The traditional Japanese family has been characterized as a tightly knit corporate group that has a nuclear family at its core and extends to include several generations of relatives. It was basically patriarchal and was patterned after Confucian family ideals and practices, that is, the family chief or head wielded autocratic authority over the family, not for his own benefit but for the good of the clan.

Structurally the family was hierarchical and was based on primogeniture and patrilineage. A recognized order of obligations and privileges governed each aspect of family life. Three basic principles governed this hierarchy: (1) the superiority and dominance of males over females, (2) the importance of age, in which the older was superior to the younger, and (3) the dominance of those born within the household over those born elsewhere. These principles were deeply ingrained and were constantly reinforced by household practices, religious doctrines, and legal codes.

One noticeable characteristic of the traditional Japanese family which can still be seen in modified form is the sense of 
group consciousness in which the identity of the individual was more or less merged into that of the group. Submissiveness to delegated authority was another characteristic. The dominant position of the male has in recent years changed to a large degree, although remants of the old traditional attitudes can still be found in society. As was noted, marriages were arranged for the benefit of the family and the personal preference or the satisfaction of the individuals involved was of secondary importance. A sense of loyalty, obligation, and duty also stands out as a strong characteristic of the traditional Japanese family and is still much in evidence in society as a whole as well as in the Japanese family.

The traditional Japanese family had some weaknesses as well as many strengths. It was a very durable family that supported and upheld the values that were cherished by society at large. Changing times have greatly influenced the traditonal family and have produced cracks in the structure of the family system and in the great heritage of moral values that have belonged to the Japanese people for centuries. This has been a cause of deep concern to many parents and educators. In an attempt to see how these changes have affected the Adventist family, several survey instruments were developed and used. The prime instrument consisted of sixty-three questions. Two copies, one to be filled out by the husband and one by the wife, were sent to each of the 935 families. Responses were received from 1,155 individuals, or 62 percent of the total population covered by this survey. Responses received revealed biographical information concerning the age, education, length of marriage, yearly income, number of children, 
and religious background and in addition gave insights into the practices and attitudes of the husbands and wives of these Adventist families. Ninety-six of the tables in this research paper are based on the Adventist Family Survey instrument and chronicle responses of Adventist spouses to such questions as to how they perceived the happiness of their marriage, the extent to which they conducted regular family worship, the influence that led to their becoming Seventh-day Adventists, the individual in their home that held final authority, their attitudes as to the importance of their children marrying an Adventist church member, the control of family finances, and the extent to which the husband and wife had considered divorce.

A second questionnaire was sent to single Adventist young people. This was sent to an available sample who were somewhat representative of the total population of Adventist youth. Responses recieved from 192 young people give some idea as to the makeup and attitudes of the youth of the church who would hopefully be forming Adventist families in the future. About 45 percent of the youth came from homes with some Adventist background. Only 1.5 percent were formerly members of other Christian churches. The remainder had either no religious influence in the home or came from homes in which the religious influence was that of some non-Christian religion.

The responses of the youth compared to that of Adventist spouses indicated that they were equally loyal and dedicated to the principle of marriage within the church. The concern expressed 
in particular by the young women was for a greater interest and effort on the part of church leaders to help them establish Adventist homes. Statistics showed that of every ten members there was slightly less than three males in the Adventist church. This imbalance was seen to be one of the greatest hinderances to the formation of more Adventist homes.

Another survey instrument was sent to the 108 Seventh-day Adventist ministers in Japan. Responses were received from ninetynine of the ministers, or 92 percent of the total. It was found that the ministers were deeply concerned about strengthening the family and were anxious to secure more training in order to make their ministry to families more effective. They indicated in their responses to what extent they were involved in various areas of family counseling and were presenting public talks and lectures on family-related topics.

Suggestions were received from ministers, youth, and spouses of united Adventist families as to how they felt the family could best be strengthened and as how they could engage in successful family evangelism. A small number of responses was also received from spouses of families in which one of the marriage partners was not a church member. Comparison of the responses from Adventist spouses of divided homes with those received from united families indicated that on the whole the divided homes were less stable and happy. On the other hand, the potential for uniting these nonAdventist spouses with their Adventist mates in church fellowship was seen to be very good since more than 60 percent were favorably 
impressed with the religious beliefs of their spouses and showed some interest in becoming church members.

\section{Insights and Convictions Related to the Family}

During the months that have passed since the beginning of this research project, many insights in connection with the family have been gained and others have been deepened. These insights have led to strong and growing convictions in regard to the task of the Seventh-day Adventist church in Japan. Certain of these insights and convictions are given below. While presented in the imperative form, they are not recommendations that have grown solely from the information gained in this study.

1. The family, as the basic unit of society, is a prime key for success in the overall work of the church in Japan. Because of this evangelism must become more family-oriented and pastoral ministry more family-centered. Man has always been and still is man-in-relationship and must always be approached as such. Especially is this true in Japan with its long history of closely interwoven hierarchical family ties.

A greater emphasis on the importance of the human family as a foundation for a stable church must first of all involve strengthening husband and wife relationships. This must even take precedence over the relationships of mother and child. The social needs of young and old, male and female, and of new and old church members must be of concern to church leaders. These must be provided with fellowship, warmth, a sense of belonging, and emotional support and security. 
A deep concern for the family has been proven successful by the Holiness and Mormon churches which have made the family the center of their evangelistic thrust and which, in turn, has resulted in stable church growth. Non-Christian Japanese religions that have grown so amazingly in the post-war years have also been largely family-centered. It is the writer's personal conviction that the Seventh-day Adventist Church in Japan must review its perspectives, priorities, and practices and give greater attention to developing and carrying out a deeply family-centered approach to its task.

2. The Japanese Christian, as an individual or as a family member, is first Japanese and secondly Christian and thus is most successfully influenced by working in harmony with his or her culture and not in opposition to it. Christianity should seek to discover those truths which have been revealed or emphasized in Japanese culture and should become as much as possible the fulfiller and upholder of the aspirations and values of that culture.

Traditional family characteristics such as group solidarity, the position of the male in the family, and the hierarchical positions of power and responsibility in society should be well understood and used as entering wedges into the family and society rather than barriers to Christianity. This means respecting and supporting established family leadership and authority figures and makes winning entire family groups to Christ and the church one of its objectives. 
3. Not only is there a largely yet unexplored potential for church growth in the divided families of the church, but the re are also inherent dangers where only one member remains a Christian. The new convert to Christianity must become an entering wedge or bridge into the family and society and not consider his or her conversion a way of escape from some family problem or from persecution. More concern should be shown for the non-Christian family members' feelings, aspirations, and frustrations. The friendship and opinions of "thought leaders" should be sought. Non-members of divided families need to be listened to more than talked to. The position of the husband in particular should be understood and supported as far as possible and his friendship and goodwill should be sought. Failure to understand the potentials and the dangers of these divided families will result in potential weakness and slow growth rates.

4. The Japanese male, must become the object of diligent and concerted study and understanding. The imbalance of more than two to one of females over males in the church is a challenge that cannot be ignored if the church is to grow. The gospel message must be re-interpreted and stated in such a way as to appeal to the practicality and inquiring nature of men. The problems and doubts that men face must be sympathetically understood. Studies must be made as to how to motivate them where they are--the market place of Japanese society. Rather than approaching these men with dogmatic authority of the minister and the message he presents, it would be better to appeal to them with reason, logic, and relevancy. 
Often the non-Christian husband is approached through the Christian wife as a means of winning him to Christ. Perhaps more difficult to master and yet more successful is the approach which upholds the position and leadership in the family of the husband and seeks to win him to Christ, and through him not only his wife but his entire family.

5. Character development and character transformation must receive far greater emphasis as integral parts of the message. Only as Christ dwelling in the heart changes lives and improves relationships in the home between husband and wife, parents and children, and brothers and sisters will Christianity become the dynamic force that Christ intended it to be. Doctrines and creeds must be made to live in the daily-life. The life and testimony of a genuine Christian is still the greatest witness to the power of the gospel. All church ministry to Christian and non-Christian alike must focus its efforts on a demonstration of the changes made in lives that the gospel, "Christ in you the hope of glory," will make in the individual and in the family.

6. The development of a truly indigenous church must occupy the highest priority in the Adventist Church. The Church must become indigenous not simply in terms of national leadership but primarily in its responsiveness to the needs, aspirations, and initiative of the local church members and leaders. Responses and suggestions received from spouses of Adventist families, from single Adventist youth, and from local church leaders indicate a wealth of ideas whose development and implementation could and should be encouraged. 
A truly indigenous church will listen both attentively and sensitively to all ideas and suggestions. It will encourage grass-roots leadership and ideas. Open dialogue and a mutual ministry within the church should be encouraged and promoted instead of a dependence on admonition, proclamation, and promotion.

7. A sensitively attuned, skillfully trained, and spiritually mature ministry will be a vital and significant factor in the development of a successful family-evangelism program. Ministering publicly and personally as he does from week to week and from day to day the minister along with his family must provide the example and the inspiration of a dedicated Christian life. The development of this type of ministry must become the objective of the formal training of ministers in their undergraduate-school program and in the on-going program of study and development during their ministry.

\section{Recommendations Concerning Family Ministry}

The recommendations related to the family and family evangelism that follow have been developed as a result of the insights and growing convictions expressed above. Successful family ministry will have a sound theological foundation and will lead to specific methodology. It also involves the emphasis and aims of a sound strategy. The methodology or particular way of approaching the challenge of family ministry would best be developed by study and experimentation on the part of interested leaders at all levels working together over an extended period of time. The following suggestions which provide areas of emphasis and proposed approaches might be further studied as part of the foundation for a strategy for family ministry and family evangelism. 
1. A broadly based and widely representative research committee should be appointed by the church to study the entire area of the family and family ministry. This committee should use every available method to secure up-to-date information concerning the family. The following are just a few areas that could be investigated: the different reasons why such a large percentage of men and women leave the church; the methods that might be used to reach more men with the gospel message; the means used by other religious organizations to win families to Christ; the means by which Adventist families can be strengthened; and the procedures that would insure a more successful family evangelism. However, this committee should go beyond gathering facts. It should seek to develop specific programs in cooperation with concerned individuals on every level of the church to help build stronger Christian families and to become more successful in winning families to Christ.

2. The Katei Kyorei Kai (Home and School Association) which has been established in many Adventist churches needs to be restudied, revitalized, and, where necessary, reorganized in order to implement the suggestions and recommendations of the research committee and to make these local association meetings more active and effective in developing happy and active Christian families. Specific training programs, seminars, workshops, and retreats should be developed and conducted in the churches. Some specific programs that might be considered and further developed are given in the following paragraphs. 
As good relationships between husbands and wives are so vital in developing strong and successful homes, programs for strengthening and enriching the marriage should be conducted. These should be designed primarily for the average, normal marriage, not for those that are deeply troubled. The seminars may be patterned after the Marriage Encounter program pioneered by the Catholic Church; after the Marriage Enrichment retreats introduced by David and Vera Mace, Quaker leaders who have been active in leading out in the area of marriage strengthening; or after some of the other programs used by other religious or social organizations. However, these should be carefully adapted to fit the situation as it exists in Japan and should be based on a deep understanding of the Japanese family and culture.

Family-life seminars for strengthening the family by helping each member understand and fulfill his God-ordained position and responsibility in the family may be conducted. These might be patterned after programs and retreats of this nature that Drs. John and Millie Youngberg of Andrews University in Berrien Springs, Michigan, have developed and conducted. The seminars would not only give counsel and instruction concerning the principles of childtraining and harmony in the family but would also involve parents and children together in practical exercises that would help to develop new habit patterns and practices. Family worship would be stressed, its importance would be emphasized, and ideas and practical suggestions could be shared and demonstrated by various families to show how it could be made interesting and effective. 
Spiritual-growth seminars and character-development and transformation retreats may also be developed and conducted. These would concentrate on promoting and developing practical godliness in the home and the practical application of character transformation as it applies to each member of the family in his or her daily life. Joint study of the counsel contained in the Bible and the Spirit of Prophecy, discussion groups, role playing, and sharing of experiences and ideas could be incorporated into these seminars and retreats.

Orientation retreats and training programs should also be conducted for newly baptized members. These should be conducted in a local church or with several churches joining together. These would help the new members become acquainted with the older church members on a more personal basis. The retreats should be designed to help new members develop the habits and practices in their own lives and families that would lead to greater spiritual growth and stronger Christian families. Depending on local circumstances and needs, specialized retreats and programs for other family-related groups could be considered. These would include programs for young married couples, marriageable-aged youth, spouses of divided homes, widows and others; they would give specialized attention to the needs and problems of each group; and they would help the various groups of church members to grow as they shared their experiences and ideas.

3. Suitable literature that relates to the Christian family and to the training and encouragement of church members and non-members 
alike should be published. This literature could be in the form of articles in Seventh-day Adventist religious journals as well as pamphlets, books, and tracts for sale or for free distribution. They should be well researched and sholid be written by those who are well acquainted with the specialized field of marriage and family, who understand the place of the family in Japanese culture and literature, and who are thoroughly grounded in the Biblical teachings and in the writings of the Spirit of Prophecy on the subject.

4. Specialized, long-range programs for unmarried Adventist youth should be organized by the Adventist Church in Japan to help in the establishment of happy, successful Adventist homes. These programs which need to be broad-based and active on the local level could be coordinated by the Young People's Department of the Japan Union Mission of the Church. Some of the areas and programs the Young People's Department might initiate, promote, and supervise are as follows:

Seminars, workshops, retreats, and discussion groups for ummarried young people which concern dating, marriage, and the establishment of Christian homes could be conducted in the local churches. In conjunction with Saniku Gakuin College, the Seventhday Adventist operated college in Chiba prefecture, classes in marriage preparation and the principles of successful, happy Christian homes should be taught.

Besides these programs designed to help the youth of the church prepare for marriage, there needs to be considerable thought 
given to specific programs that would help single young Adventist men and women meet prospective mates and establish Christian homes. More than fifty percent of the young people questioned indicated dissatisfaction with what the church was doing to help them establish Christian homes. Two suggestions in particular need to be explored to help remedy this failure: (1) Local church leaders should take the initiative in helping to arrange more opportunities for young people to have close fellowship in social gatherings and in group religious activities. (2) Some kind of master-dating file service should be established to help interested youth to meet and get acquainted with prospective mates. This suggestion was of particular interest to the older Adventist youth. These suggestions should be given careful consideration and the most skillful methods available should be used and developed in close cooperation with the young people themselves.

Another area that should be considered and carefully planned is the maintainance of communication and dialogue with those young people who have married outside the church. Perhaps lists of these young people could be prepared and updated periodically by each church so that contact can be made with these people on such important occasions as the birth of children, wedding anniversaries, graduations, marriages, and deaths. Of course, plans should be laid to include them in special church and family programs as well. The objective of this program should be to help these young people, who by marrying a non-church member have gone against the advice and counsel of the Church. They need to feel love and acceptance to 
help them remain faithful to the Church and to win their non-Adventist family members to Christ.

5. A specialized training program to develop qualified church leaders for marriage counseling and family ministry should be developed and carried out. This program should begin in the preparation given ministerial students in their undergraduate training at Saniku Gakuin College. It should also provide opportunities for specialized training during their pastoral ministry. The following specialized programs are a few that could be considered: (1) recommended reading and correspondence courses in family counseling and marriage-related fields; (2) in-residence training at some specialized marriage counseling training center; (3) retreats, workshops, and seminars conducted by experts in the field of marriage counseling; and (4) enrichment-type programs. Academic credit might be arranged for some of these programs.

It would also seem advisable to encourage a few qualified individuals who are within the church and who have a strong religious foundation to secure specialized training in marriage counseling. These specialists in family counseling could be a positive help to ministers and church. They could also use this form of ministry in the community to reach non-Christians with the Gospel.

To Christians living and laboring for souls in the changing and challenging land of Japan, the task of presenting Christ and His Message is an awesome one. The fear of "the swamp" need not daunt them, but they should be seriously challenged to adapt themselves more radically to the culture of this land. They must 
seek to broaden their influence by a deepening concern for the family according to Japanese traditions. They must seek more fully to understand the spirit of the times, to empathize more completely with the loneliness, confusion, and emptiness that have filled so many hearts as a result of the rapid changes in age-old patterns of family living and culture. They must have the wisdom and courage to develop new approaches to entire families and meet them on their own ground. Christianity must not be presented as a foreign ideology that comes to destroy and supplant their traditional values and aspirations. It must be presented as the culmination and unifier of all that is good in the old, the framework within which personal self-hood can grow to complete maturity, and the foundation upon which family relationships leading to inner peace and a sense of fulfillment will develop. 
A P P E N D I C E S 
APPENDIX A

SEVENTH-DAY ADVENTIST FAMILY SURVEY

Letter of Instructions and Questionnaire in English and Japanese 
To all Seventh-day Adventist

Husbands and Wives in Japan

Dear Friends,

Christian greetings to each one of you. For those who do not know me let me take this opportunity to introduce myself. I am Warren Hilliard and I have had the privilege of working for more than twentyfive years in various areas of Japan. At present $I$ am head of the Bible Department of Nihon Saniku Gakuin College.

As I look at the work of God in Japan I am keenly aware of some very real difficulties and problems. Recently I had the opportunity of spending a year at Andrews University. While there I sought for answers to some of these problems as I studied for a degree in Doctor of Ministry. I became deeply impressed with the need to learn more about the Japanese family as a means of reaching more non-Christians in Japan with the Gospel. In particular, it seemed to me, a deeper understanding of the situation and attitudes of the Seventh-day Adventist family in Japan would be extremely helpful.

I would greatly appreciate it if each one of you would cooperate in sharing information concerning your family. With your help, we can gain a clearer understanding of the strengths and weaknesses of the Adventist family here in Japan. This information will not only be helpful in knowing how to strengthen our Adventist families, but it will also help us to know how to work more successfully through these families to win friends, relatives, and neighbors to Christ.

The completion of this questionnaire will take about $30-40$ minutes of your time. Two questionnaires are enclosed, one for the husband and one for the wife. Some may wonder why both husband and wife are asked to fill out the blanks. Although in most things husbands and wives may think alike, there are some differences that we believe are very important to understand. We assure you that all information will be kept strictly confidential.

I want to thank each of you for your cooperation in taking the time and effort to assist in this project. If at all possible, complete and return the questionnaires to me within five days of the time you receive it. A self-addressed, stamped envelope is enclosed for your convenience.

Sincerely yours, for more united families in Christ,

Warren I. Hilliard, Saniku Gakuin College 


\section{SEVENTH-DAY ADVENTIST FAMILY SURVEY}

A. Biographical Data

1. Place a check by your appropriate sex.
1. Female
2. Male

2. Into which of the following age categories do you fall?
1. Under 24
5. $40-49$
2. 25-29
6. 50-59
3. $30-34$
7. 60 and
4. $35-39$
over

3. How long have you been married to your present spouse?

1. Less than 2 years

2. 2-5 years

3. 6-9 years

4. 10-14 years

5. 15-24 years

6. 25-34 years

7. 35 years or more

4. How much difference in age is there between you and your spouse?

1. Husband 1-2 yrs. older

2. Husband 3-5 yrs. older

3. Husband 6-10 yrs. older

4. Husband more than 10 yrs. older

5. Wife 1-2 yrs. older

6. Wife 3-5 yrs. older

7. Wife 6-10 yrs. older

8. Wife more than 10 yrs. older

9. Husband and wife same age
5. Which of the following describes your marital status?

1. Married once and still 1iving with that spouse

2. Second marriage, first spouse died

3. Second marriage, first ended in divorce.

6. Which of the following best describes how your marriage partner was chosen?

1. Marriage partner was chosen by my parents

2. Marriage partner was chosen by myself

3. Other methods

7. Which of the following best describes the form of your marriage arrangement?

1. "Miai" marriage arrangement

2. "Renai" marriage arrangement

3. Other methods or combination

8. How well acquainted were you with your spouse before your marriage?

1. Not acquainted at all

2. Only slightly acquainted

3. Rather well acquainted

4. Very well acquainted

9. How long was your engagement?

1. 1-3 mos. 4. 1-2 yrs.

2. 4-6 mos. 5. over 2 yrs.

3. 7-12 mos. 
10. What is the level of your education?

1. Junior high school

2. Senior high school

3. Junior college

4. Senior college

5. Graduate level

11. What is the level of the education of your spouse?

1. Junior high school

2. Senior high school

3. Junior college

4. Senior college

5. Graduate level

12. To what extent are you presently employed?

1. Full time

2. Part time

3. Retired

4. Unemployed

13. What is the employment category of the major wage earner of your family?

1. SDA employee

2. SDA colporteur

3. Self-employed (not including colporteur)

4. Salaried--largely skilled

5. Salaried--largely manual

6. Professional or managerial

7. Other

14. To what extent is your spouse presently employed?

1. Full time

2. Part time

3. Retired

4. Unemployed

15. What is the employment category of your spouse?

1. SDA employee

2. SDA colporteur
3. Self-employed (not including colporteur)

4. Salaried--largely skilled

5. Salaried--largely manual

6. Professional or managerial

7. Other

16. Into which of the following categories does your yearly family income fall?

1. Less than one million yen

2. One to three million yen

3. Three to five million yen

4. Over five million yen

17. Do you own your home or are you renting?

1. Own home

A. Living in it

B. Renting it out

2. Do not own home

A. Renting or living in employer-furnished housing

B. Living with parents

\section{B. Data Concerning Children}

1. How many children in your family?

1. None

2. One

3. Two or three

4. Four or five

5. Six or seven

6. Eight or more

2. What are your attitudes and practices toward the discipline and training of your children?

1. Authoritarian

2. Permissive

3. Democratic

4. Combination of above or other 
3. Do you and your spouse have the same attitudes and practices toward the discipline and training of your children?

1. Yes, basically the same

2. No, quite different

3. Sometimes agree, sometimes disagree

4. Do you and your spouse disagree in front of your children concerning their training and discipline?

1. Usually agree

2. Usually disagree

5. Which of the following best expresses your feelings as to the need for education?

1. A junior high school education is sufficient

2. A senior high school education is sufficient

3. A college education is necessary

4. Learning a trade is sufficient

5. Other--please specify

6. Have you "sent (or are you now sending) your schoolage children to a Seventhday Adventist school?

1. Yes

A. All of them

B. Some of them

2. No--for the following reasons

A. No SDA school is near

B. Financial reasons

C. Adventist schools are inferior

D. Children's or family's personal desires
7. If you as a parent could influence your oldest son to choose his life's work, which of the following would you encourage him to choose?

1. Farming

2. Self-supporting business

3. Carry on family business

4. Salaried man in dependable firm

5. Adventist colporteuring

6. Salesman

7. Politician

8. Skilled labor

9. Medically-related employment

10. Teaching profession

11. Gospel ministry

12. Technician

13. Clerk or office worker

14. Other

8. What do you feel are the most important things you as a parent can do to help your children make a personal decision for God? (Check three)

1. Provide Christian education

2. Pray for them

3. Love and encourage them

4. Give them proper training and discipline

5. Provide a consistent example of Christian living

6. Other

9. How important is it to you that your children marry a Seventh-day Adventist?

1. Very important, strongly oppose marriage to nonmember

2. Very important, but I would leave decision to children

3. Not too important--their own happiness is most important 
10. Formerly Japanese parents had a great deal to do with arranging marriages. Now times are changing. Which of the following best expresses your feelings?

1. Children alone should make own decision

2. Children should make own decision but with parents approval

3. Parents should have the right to veto any decision

4. Parents alone should make the choice for the child.

11. Are you in favor of "renai" or "miai" marriage arrangements for your children?

1. "Renai"

2. "Miai"

3. Either

12. List below by sex and age whether your children attend religious services regularly or not. Check appropriate columns.

\begin{tabular}{|l|l|l|l|}
\hline Sex & Age & $\begin{array}{c}\text { Attend } \\
\text { Services }\end{array}$ & $\begin{array}{c}\text { Do not } \\
\text { Attend }\end{array}$ \\
\hline$M F$ & & & \\
\hline$M F$ & & & \\
\hline$M F$ & & & \\
\hline$M F$ & & & \\
\hline$M F$ & & & \\
\hline
\end{tabular}

C. Religious Life in the Family

1. What was the religion of your parental home when you were growing up?

1. No religion

2. Nominal Buddhist or other Japanese religion

3. Strict Buddhist or other Japanese religion

4. Nominal non-Adventist Christian

5. Strict non-Adventist Christian

6. One parent Adventist

7. Both parents Adventists

8. Both

2. What generation of Seventh-day Adventist are you?

1. First generation

2. Second generation

3. Third generation or more

3. Do you at present conduct family worship in your home?

1. No

2. Occasionally

3. Regularly in morning only

4. Regularly in evening only

5. Regularly both morning and evening

4. Who leads out in family worship?

1. Husband usually

2. Wife usually

3. Other

5. Do you and your spouse pray aloud together?

1. Never

2. Occasionally when problems arise

3. Regularly

6. Do you attend church when at a11 possible?

1. Yes, regularly 
2. Yes, occasionally, at least once a month

3. Hardly ever

7. Which of the following Seventh-day Adventist church papers do you read regularly?

1. "Signs" only

2. "Adventist Life" only

3. Both of the above

4. Neither of the above

8. How many books written by Ellen G. White do you have in your home?

1. None

2. Three volumes or less

3. Four to ten volumes

4. More than ten volumes

9. During the past two years have you held an office in your church?

1. No, I have not

2. Yes, I have

10. Do you believe prayer and religion have helped to make your home happier?
1. Yes.
2. No
3. Not sure

11. Which of the following do you find most helpful in the development of your spiritual life?

1. Pastor's sermons

2. Sabbath School classes

3. Prayer meetings

4. Private daily devotions

5. Religious radio programs

6. Reading religious books

7. Counseling with pastor

8. Other--please specify
12. Did you become a Seventh-day Adventist before or after your marriage?

1. Both husband and wife baptized before marriage

2. Both husband and wife baptized after marriage

3. Wife baptized before and husband after marriage

4. Husband baptized before and wife after marriage

D. Happiness and Stability of Marriage

1. How would you classify the success and happiness of your marriage?

1. Very satisfactory

2. Relatively satisfactory

3. Relatively unsatisfactory

4. Very unsatisfactory

2. How would you describe the progression of the happiness and success of your marriage?

1. Increasing as time goes on

2. It is getting worse

3. It is about the same

3. Which of the following potential areas of friction have caused the most conflict, if any, in your marriage? Check three.

1. Personal differences

2. Criticism, nagging

3. Use of time

4. Money

5. Emotions, moods

6. Children

7. Communication, or lack of it

8. Relatives, in-laws

9. Work, own or spouse's

10. Sex

11. Faith and religion

12. Other

13. Spouse's friends

14. Bad habits of spouse 
4. Have you ever thought of divorce as a solution to your marriage problems?

1. Yes, seriously

2. Yes, but not seriously

3. No

5. How would you classify the sexual relations between you and your spouse?

1. Very satisfied

2. Not too satisfied

3. Dissatisfied

4. Cause of real problem

6. Which marriage partner do you consider to be more mature with greater emotional stability?
1. Husband
2. Wife
3. About the same
4. Don't know

7. How would you rate the level of understanding and communication between you and your spouse?
1. Poor
3. Good
2. Fair
4. Excellent

8. Do you and your spouse argue and quarrel?

1. Often quarrel heatedly

2. Frequently, but not too seriously

3. Seldom quarrel as have little in common

4. Seldom quarrel aloud but remain silently antagonistic

5. Never quarrel at all

9. Do you and your spouse have a mutual activity or hobby aside from your work? If you answered yes, please specify.

1. Yes

2. No

\section{E. Dynamics of the Family}

1. What was (or is) the employment of your parents?

1. SDA employee

2. SDA colporteur

3. Self-supporting (not including colporteur)

4. Salaried--largely skilled

5. Salaried--largely manual

6. Professional or managerial

7. Other

2. In the home in which you were raised where would you say the final authority lay?

1. My father

2. My mother

3. My grandfather

4. My grandmother

5. Joint parental authority

6. Extended household or clan consensus

7. Other

3. In your own home, where would you say the final authority lies?

1. Husband

2. Wife

3. My father

4. My mother

5. Joint husband-wife authority

6. Extended household or clan consensus

7. Other

4. Who controls the finances in your home?

1. Husband almost entirely, with allowance for wife

2. Husband controls major decisions, wife day-to-day finances

3. Wife almost entirely, with allowance for husband

4. Joint control, mutually decided upon

5. Other 
5. Do you think it desirable for the wife to work outside the home?

1. Yes, if husband and wife agree

2. No, not while children are small

3. No, it is never desirable

4. Other

6. When you got married, did your parents approve of your marriage?

1. Yes, they approved

2. No, they are still strong1y opposed

3. Formerly they were opposed but now they approve

4. Neither approve or disapprove

7. What were the strongest influences in your becoming a church member? (Check three)

1. Public evangelism

2. Reading religious literature

3. Influence of friend

4. Influence of spouse

5. Influence of parents

6. Adventist education

7. Sabbath School, regular or branch

8. Religious radio broadcast

9. Bible correspondence course

10. Pastor or other evangelistic worker's efforts

11. Other

8. To what extent is your family involved in friendship with other families in your neighborhood?
1. Very 1ittle, our intimate friends are largely church members

2. To a great extent, our intimate friends are largely among non-members

3. We have about an equal number of friends among members and non-members

9. What suggestions do you have that will help the Adventist family reach non-Adventist relatives, friends, and neighbors?

10. Which of the following best expresses your attitude toward Adventist health teachings?

1. I gladly live in harmony with this message.

2. I understand it but do not follow it.

3. I do not really understand it clearly.

4. I'm not interested in it.

11. Which of the following do you find the greatest source of problems in your home in connection with church standards?
1. Television
2. Reading matter
3. Music
4. Sports
5. Other, please specify

12. Who leads out in your home in trying to uphold the standards as listed in question 11?

1. Husband

2. Wife

3. Children

4. All together

5. No one takes responsibility

13. In the following space write your suggestions concerning standards in the home for healthful living, recreation, music, sports, games, and so forth. 
The following two questions should be filled out only by Adventist spouses of divided homes.

14. What is the attitude of your spouse (if a nonmember) toward the SDA church?

1. Strongly opposed

2. Somewhat opposed

3. No interest but does not oppose

4. Some interest

5. Strongly interested

15. In the space below write your suggestions as to the best way to win a nonAdventist spouse to Christ. 


\section{敬㿿するアドベンチスト效会舅の皆樣}

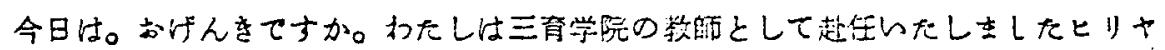

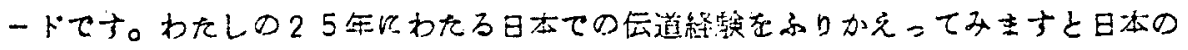

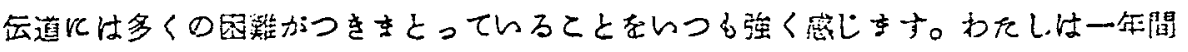

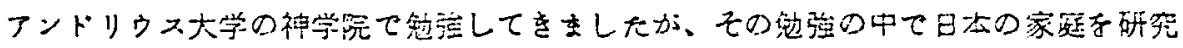

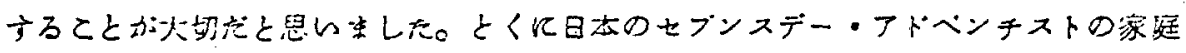

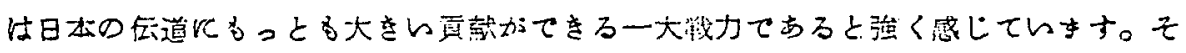
ててあなたにぜひ一つのととすかかがしたいのてす。

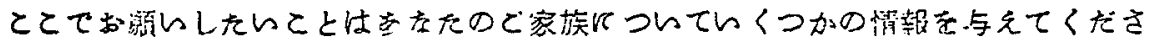

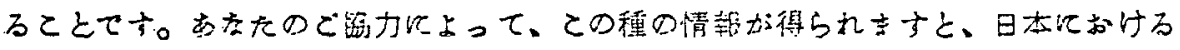

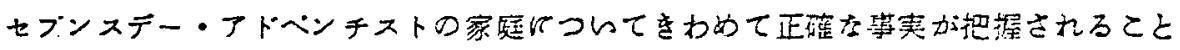

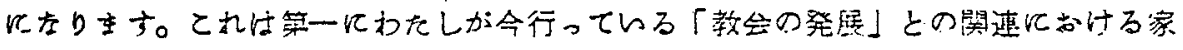

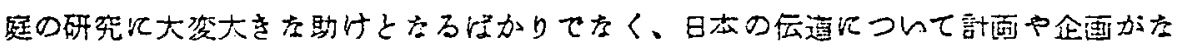
される際の参考算料として有效に周いられると信じす。

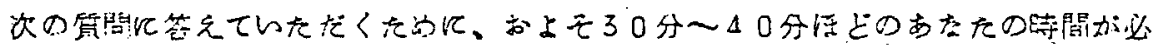

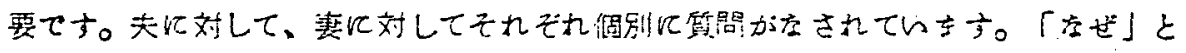

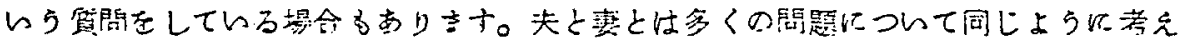

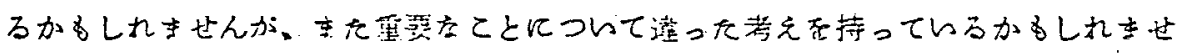

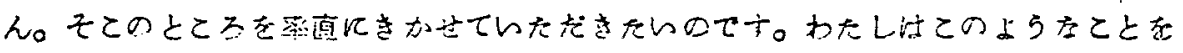

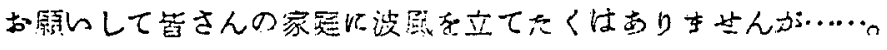

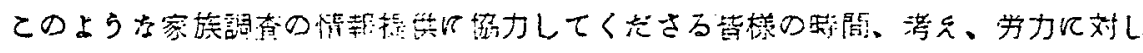

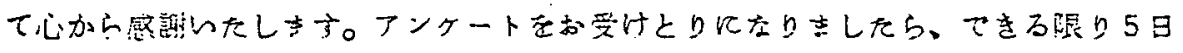

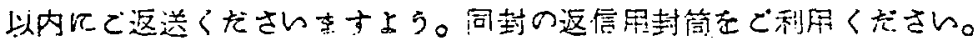

キリスト以ある一致した宾突のため比をて的て

1975 年12月8日

ワレン・ヒリヤード

日本三充学院神学科

\section{〔記入の仕方にっいて〕}

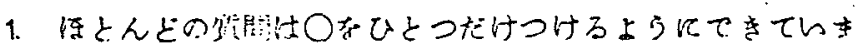

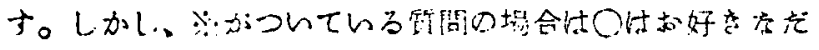
けいくつでっつてくだん。

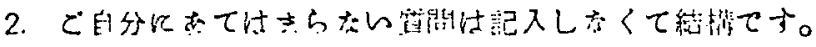

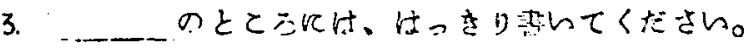

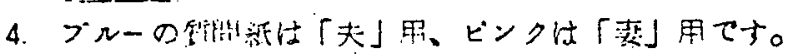


セブンスデー・アドベンチスト家仼调盗

一家庭生活調查—

\section{A゙．家庭の基整的なことについて}

1. あたたの性期に○をつけてくださ。
(1) 女
[2] 男

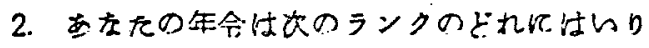

\section{ますか。}

[1] 24 才以下

[5] 40 拁的 9オ

[2] 25才加29才

[3] 30 加 34 才

[4] 35才加39才

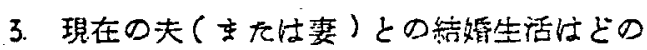

くらんの期間つづんていますか。
(1) 2年末满
[5] $15 \sim 24$ 年
[2] 2 年以上5年まで
[6] 25 34 年
[3] 6 9 9年
[7] 35 年以上
[4] 10 年一 14 年

4. あをたの年令と夫(むたは事)の年命を比 較しますと、どれくらい年令差がありすす か。

四わたしの夫(また沬妻)はわたしより 年上てす。
(1) $1 \sim 2 才$
(3) 6 - $10 才$
(2) $3 \sim 5 才$
(4) 10 才以上

[2] わたしの夫(または妻)はわたしょり 年下てす。
(1) $1 \sim 2 才$
(3) $6 \sim 10 才$
(2) $3 \sim 5 才$
(4) 10 方以上

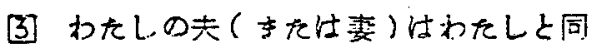
じ年令てち。

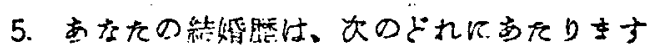
か。

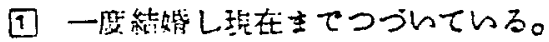

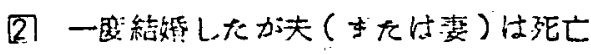 L.Ko

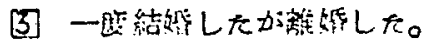

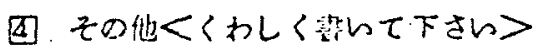

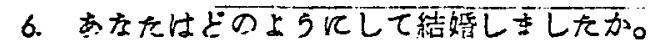
下の中からえらんてくださん。

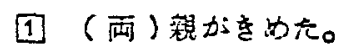

[2] 自分视虾。

[3] [12以外のの淤めた。

7.ビの上らを経過をたどって結婚しすしたか。 [1]兒合的 2]恋愛 回之の他

8. 絽福する前、現在の夫(または妻)をどの 程匿知っていしたか。

[1] 全く知らたかった。

[2] 少し知っていた。

[3] 古り知ってい充。

[4]上〈知っていた。

9. 蛅約期閶が西りましたら、どれくらいてし. たか。
[1] $1 \sim 3$ 月
团 1 年一 2 年
[2] 4 一 6 月
(5) 2 年以上
[3] 7〜12 月

10. あ存九の最終教骨は次のどれルあたりす 加

[1]学校卒(旧高等小学校)

[2] 高等学校卒(旧制中学校卒)

[3] 智大卒 (各種学校卒)

[4]四年兟快学卒 (尃門学校卒)

[5] 大学院卒

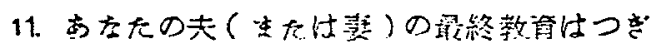

のらちどれ尤片ますか。

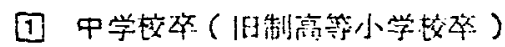

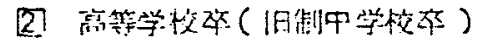

[3]短大卒(各程学恔卒)

[4] 四年制大等等(渄学校卒)

[5] 大学院禖 
12. あな大性在どれくらい動いてい主すか。

[1]フタイムて（全时間)て锄ている。

[2] ジートタイムて微ている。

[3] 退聇している。

四 堑琼

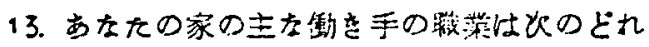
にあたりますか。(すし遈端している場合

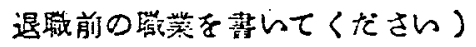

(1) S D A 教団の動 人

22] SDA交書伝道者

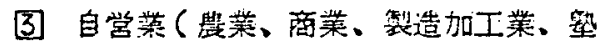
経営その他。)

【《㕍居されている。主として事務、企画 営業、美街、放送存ど知的労㗢をして 々る。

[5] 㕍用されていろ。主として販売や列造 修理建築左との为仕学䧿在している。

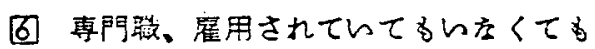

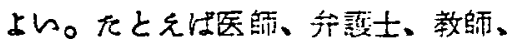

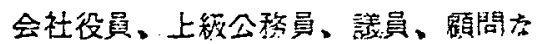
ह。

[7]ての他。

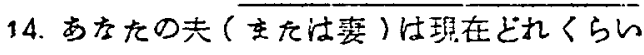
微いていますか。

[1]フルタイム(全時間)て㯎いている。

[2] ハーートタイムで陲らている。

(3) 退職している。

【) 然漛

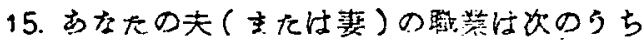

B. 子供について

1. 古たの子期の数仕何人てすか
(1) 古以
[4] 4.5人
[2] $1 \wedge$
[5] 6.7人
(3) $2.3 \wedge$
[6] 8 人以上

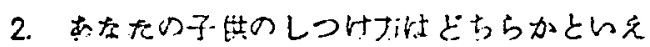
代次のビれんかたり末すか。

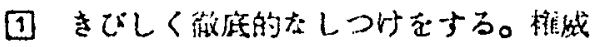
主妾的。
どれにあたりますか。

(1) S D A 教団の儌委人

[2] S D A 文思层道者

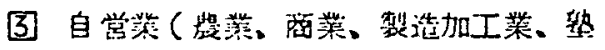
経営、その他。)

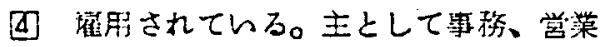
美術、放送左ど知的労徽をしている。

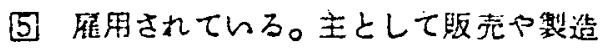
修理垡築古どの为体労衙をしている。

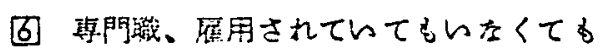

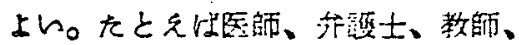

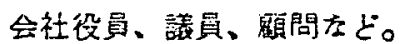

[7] その他

16. あ古たの家䶭の収入仕次の民゙れにはいらす 士か。

(1) 収100万螴满

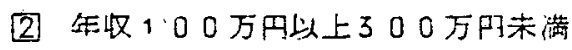

(3) 年收300万凡以上500万円米满

《年虹 500 万中以上

17. 古をは自分の家老持っていすす（夫ま たは奏の家てるよん)

[1] 持っている。(次のどれかル○をつけ てください)

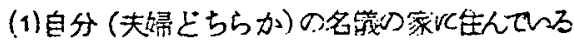

(2)他人貸沉てる。

[2] 持っていない(饮のどちらかル○れ つけてください)

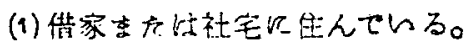

(2) 新の名的の家に应んている。

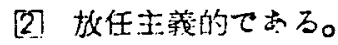

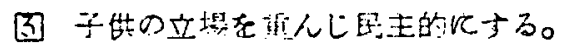

[4] その他

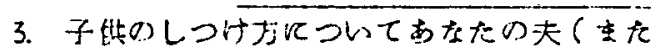

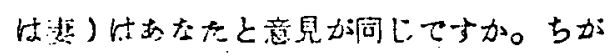
っていすかか。

[1] 问して子。 
[2] ちがいすす。

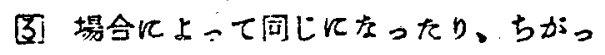
たりします。

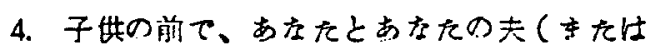
靑)は対立するととがすりすか。

(1) 子供の前て対立するとと山ない。

[2] 子鿁の前て対立ずるととかしばしばあ る。

5. あおたのお子さんの教骨はどの程策したら 上レと考えていますか。

(1) 中学校で十分

[2] 高等学校て十分

[3] 大学教育加必要

【四手飞㖒をつけるてとが必要

[5] その他

6. あた九のお子さんをSDAの学校に入れま したか。西るいは現在いれていすすか。
(1)入れ西した
(1) 子供全部

(入れています)

[2]子供たちの5ち何

$$
\text { 人加 }
$$

[2]・入九せんてした。その理由は，

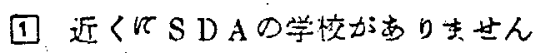

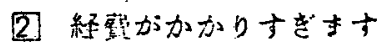

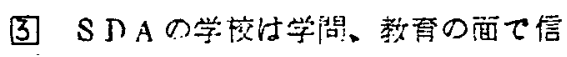
㛀てきさせん

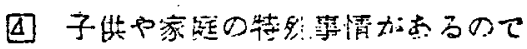

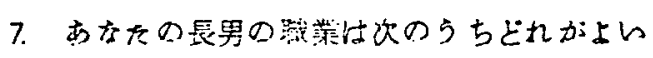
と思的すな。
[1] 農業
[8] 整練学謜者
[2] 自觉策
[9]医者、医壻閔保

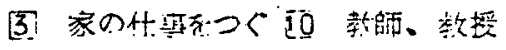
《会社?
[1] 牧拓
[5] 文数公通者 回技術者
[6] ヒールスマン [3] 称
[7] 欧范筑 回 その他

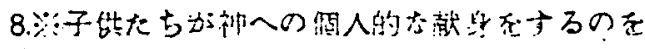

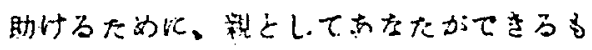

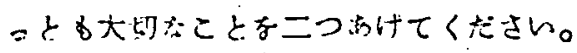

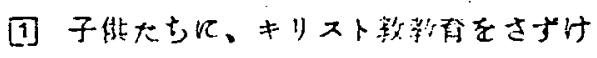

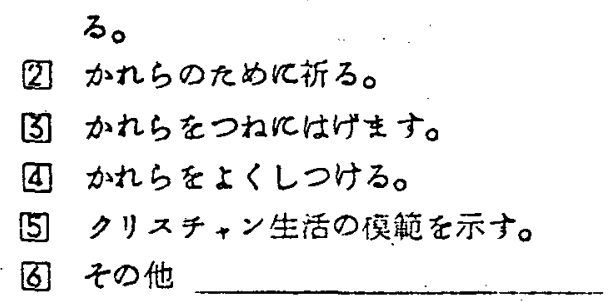

9. あ左えのお子さんか D D 教会員と結婚す るととは、どれくらん大切をとと考えて いすすか。

(1) 非常以重學てす一未信者との結婚に 絶対反対。

[2] 重要てす。一しかし子供の選规にす かせます。

[3] あすり重要でい一子供が幸福にな 九仕上的。

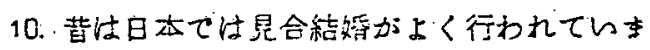
Lれ。現在あなたは綕婚のしかたについて とん考えをすていすすか。次のら古ど 九があなた考えをあらわしていると思い すか。

(1) 自分てえらび新の干涉を受けない。

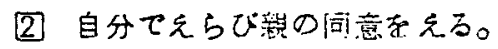

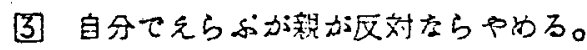

【自分てえらばす就の意兒以したから。

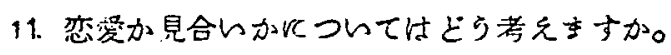

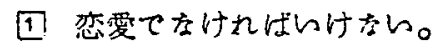

(2) 見合の方からい。

[3] 恋愛ても見合てもどらですい。

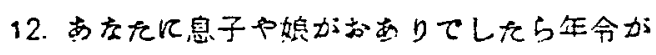

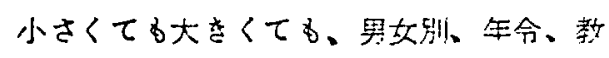
会化出底しておられるかどうかか教えくた さn。

\begin{tabular}{|c|c|c|c|c|}
\hline 性 別! & 年轨 & 令 & 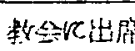 & している \\
\hline 男 女 & & 才 & は & 光々た \\
\hline 男 女 & & オ & \& & hhょ \\
\hline 哭 女 & & 才 & H is & hus \\
\hline 男 女 & & 才 & H n & $\sin \pi$ \\
\hline 朋 女 & & t & 山 & nht \\
\hline
\end{tabular}




\section{C. 宗教にっいて}

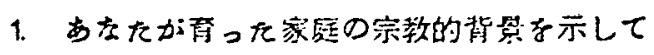
ください。

[1] 全く宗教と無舆保の家庭

[2] 名目だけ日本の宗教るつつ家㩆

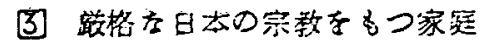

[4] 名目だけのクリスチ+ン（SDA以外 の)家定。

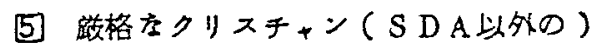
家䞨。どの教会か群記してくだい。

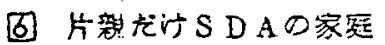
[7] 両数かSDAの家莛
[8] その他（明記してください）

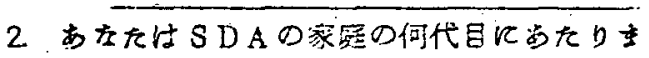
†か。

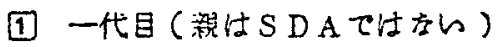

[2] 二代目 (親加S DA)

[园 三代吕以上

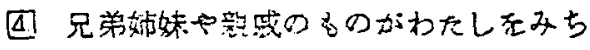
びいてくれた。

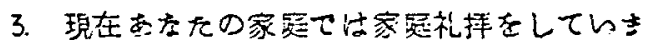
す加。

[1] 的充

[2] 時々します。

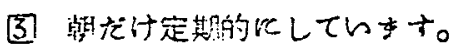

【! 晩大゙忖定斯的にしていすす。

[5] 斯挽定期的化していすす。

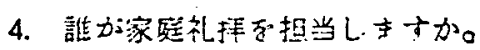

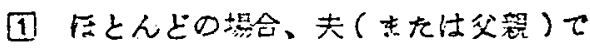
†。

[2]仼とんどの坦命、装(すたは母視)て t。

[3]その他。誰心洞記しててださん。

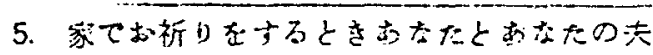

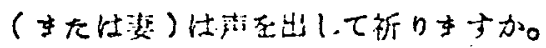

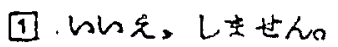

[2] 問題がてったときたどはしすす。

[3] んつもしています。

6.あすたは教会行出していすすか。

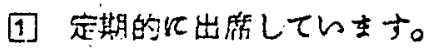

[2] 月几一弫ぐらい出席します。

(3) 在とんど出席しをん。

7.あなたはS DAの雍誌を梳んていすすか。

(10 サイズたけ㳟みすす。

[2]ライフだけ読みすす。

[3] 両方と就子す。

团どちら讜みません。

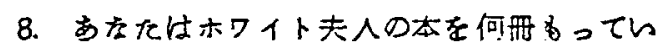
ますか。

(1) 全然。てい尚。

[2] 3 册以下。

[3.) 4 舟から 10 冊。

《) 10 舫以上。

9. 调去二年門、教会役員をしたととがありま

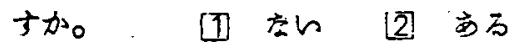

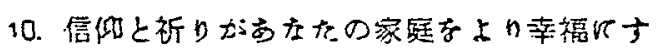
ると信しますか。

(1) けん、信しすす。

[2] レレネ、信しません。

(3) かかいま计。

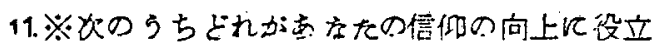
つと思いすか。三つおけててくさい。

[1] 牧霜の説教

[2] 安息日学校のクラス

[3] 新稿会

[4] 值人的左新

[5] ラシカのキリスト数孚积

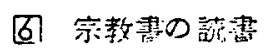

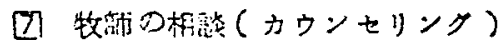

[8] ての他、明記しててください。

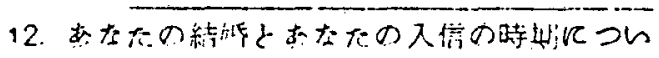

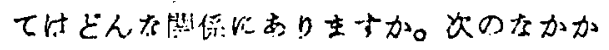
ら笭皇てください。 
(1) 結蚳ナ万前にわたしるわたしの夫(す た(淁)すSDAてした。

[2]結婚したあとに、わたしすわたしの夫

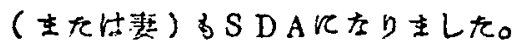

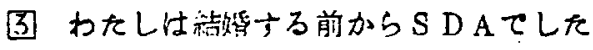
がわたしの夫(または泟)は結稓し た後てSDArなりました。

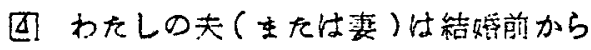
SDAてしたか、かたし壮結福したあ とてSDAK古りまL和。

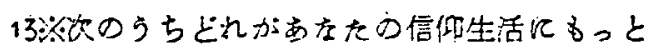

る役立っていると思いすすか。三つえらん てくださ。

(1) 站師の説教

[2] 安息日学惟のクラス

3] 析裂会

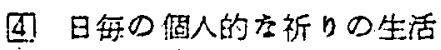

[5] ラシオのキリスト教番組

[6] 宗敦関係の塄薄

[7] 牧師との相談(カゥンセリンク)

[8] その他〈具体的几>

\section{D. 家庭の安定度と满足感について}

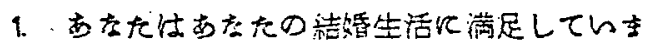
广か。

(1) 非常に灌尽している。

[2]. 大体满足している。

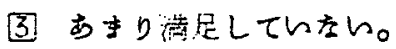

《] 全〈不满尼て高る。

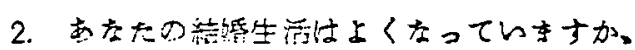
わるく古っていすすか。

(1) 封がつにつれて上くなっている。

[2] 方地つれてわるくなってい。

(3) 以龍落わら的。

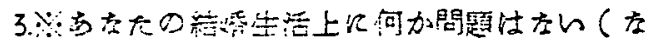

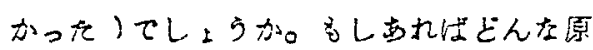

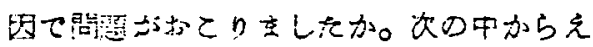
らんてくだん。

[1] お金

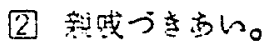

[3] 七っクス(性生活)

(4) 互いの批制、不平、小言。

[5] 知㛎のち淤。

(6) 子姑のしつけや教育。

[7] 倍仰や宗教。

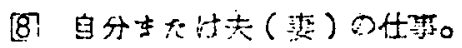

[9] 家铞内の芯志の深通。

团感骦、父份。

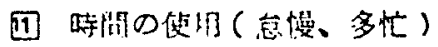

(2) 悪㾋
[3] 夫や妻の友人。

四 その他 (具体的原)

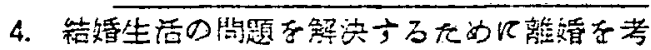
そたととがありすすか。

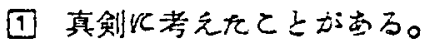

[2]余り真釗でないか栲えたととがある

(3) 考充たととは的。

5. あたたとあなたの夫（きた菈）の性的生

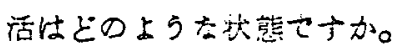

(1) 大体满足している。

[2] 甶摆的て会り灌足していない。

(3) 不满てある。

【]不和の原図に索っている。

6. あ左大が夫夫婦のらちどちらがより安定い。 ていますか。

[1] 夫

[2] 素

(3)二人と的大煳同。

【1 わからを的。

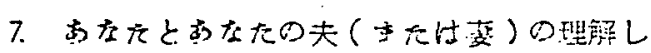

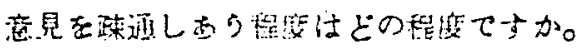

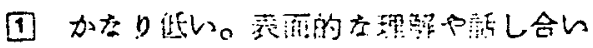

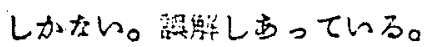

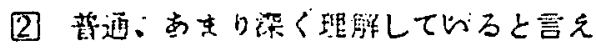
tho

(园 良い、上く理解しているし話し、合って 
n3o

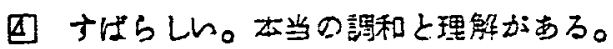

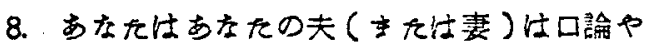

けんかをしすすか。

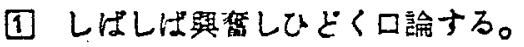

[2]ときどするがあり梁刻でない。

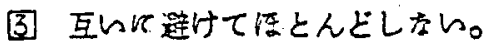

凹黙ったます対立する。
[5] けんか、口論のたぐいは全くない。

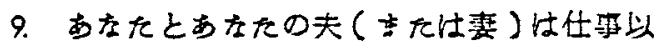

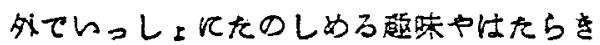
をるっていすすか。

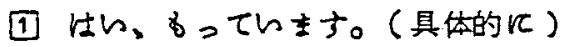

[2] らレえ.ありません。

E. 家庭のダイナミックス(活動力)について

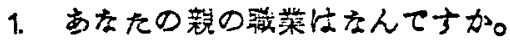

(1) SDA 教団の㗢衣人

[2] S D A 文畫伝道者

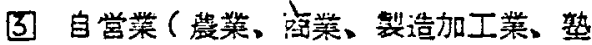
経営、その他)

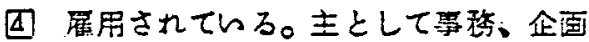
美術、放送支ど知的觉㗢をしている。

[5]鹰用されている。主として販売や旼浩

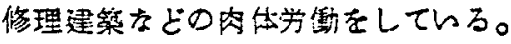

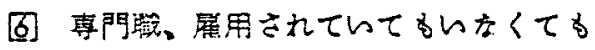

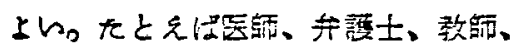
会社役員、上铞公務員、議員、磷問左 غ゙。

[7] その他

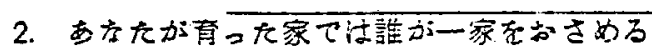
権威をるってい主したか。
(1) 父
(5) 雨新
[2] 母
[6] 新族今議
(3) 祖父
[7] その他
(4) 祖

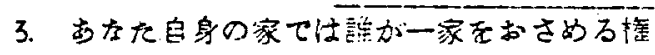

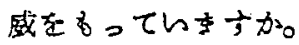
[1] 夫
[5] 夫貄
[2] 凄
[6] 覣族会馀
[3] 夫の文
[7] テの他
[4] 夫の贯

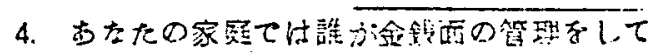
几土すか。

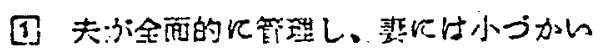

を与える程蜜。

(2) 夫名大古決定権をつつが妻が日每の 家計をつ。

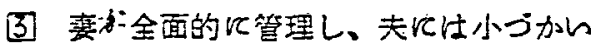
を与える很。

四 夫婦て話し合って管理する。

[5] その他

5. あなたは妻が外で舅くことを望きしいと思 いますか。

(9) ると婦の意見が一致していれば㕵ま しいと思う。

[2] 子供がさい閔壮望さしくない。

[3] 全く望主しく衣い。

《] その他

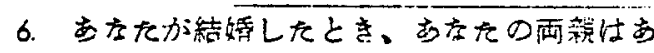

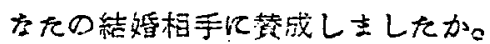

(1) 茧成した。

(2) 今すつ上く反対している。

31 以前はつよく反対しましたが、今江替 戌しらまくんっている。

凹筫成る反詨当したかった。

[5]その他

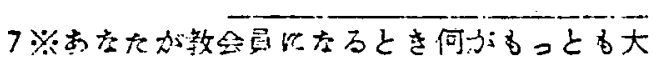
きい影整を与えましたか。三つあげてくだ さh。

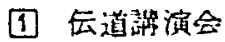

(2) 宗较敖んたとと。 
[3] 友人の感化。

【む夫(または要)の感化。

[5] 両親の感化。

[6] ヒブンスデーの学校。

[7] 安息日学校

[8] ラジオのキりスト教放送。

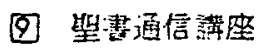

[可牧師や会道者との会話やかれらの励士 L。

囵 その他

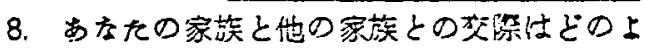
5反をってい支吉加。

(10 親しい交祭は教会員とだけっっている。

[2] 親しい交然仕得とんど教会外の人たち $\tau$ †。

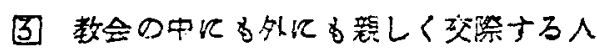
がある。

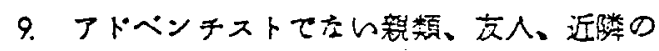

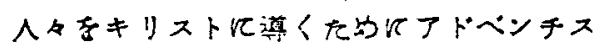

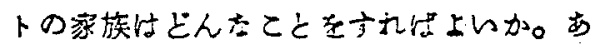
なたので意見を書いてく於さい。

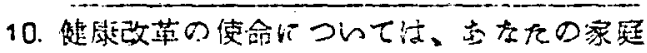
で.

(1) 憘んて实行している。

(2] 理解しているが䔬行していたい。

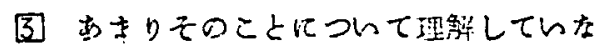
ho

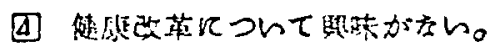

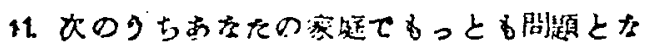
ニているの古んてすか。 (1) テレビの見なき。
[2] 有害古䛨慧。
[3] 低級古音案。
【過げををスボーッ
[5] その他

12.上の侗間てっとす問題となっているすの について化次のらち誰が責任持っていま すか。

回夫凹孙死で共同に

[2] 妻 [5] 誰子翼任を持ってい去い

[3] 子姑をち

13. 健索改革の使命、アドン゙ンチストとし、て家 廷ての教荃、レクリエーション、県楽、ス ボーッ、ゲーム古どていて自由にあなた の意見を書いてください。

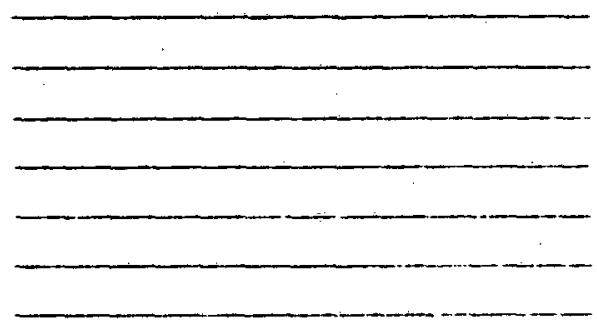

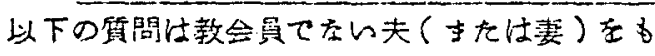
っておられる万たけか答んくたさい。

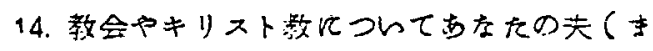

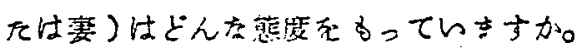

(1) 强的反発京している。

(2] 垫え目板対走している。

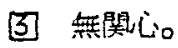

(4) 奸意的。

[5] 强閣心死っていら。

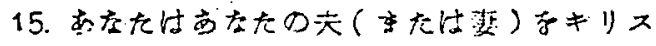

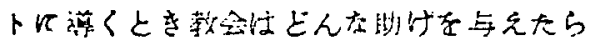

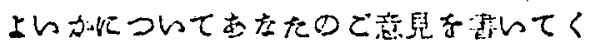
ださ。 
APPENDIX B

UNMARRIED SEVENTH-DAY ADVENTIST YOUTH SURVEY

Letter of Instructions and Questionnaire in English and Japanese 
December 4, 1975

Dear Young Adventist Friend,

The enclosed questionnaire for single Adventist young people is one of three that $I$ am using in my study of the Adventist family in Japan. Another questionnaire is being sent to Adventist ministers, and still another is going to every Adventist family in Japan. All the questionnaires will be an aid in my doctor of ministry project.

The purpose of all these questionnaires is to find out all we can about the Adventist family in Japan in order to help strengthen and protect it from the various pressures of society that are attacking it and to help make the family more effective as a means in winning others to the church.

God has given man marriage and the family system as a gift of love. Rightly understood and entered into it is a great blessing. However, the devil has used marriage and the family and various family-related relationships to attack man and cause unhappiness and sin.

This questionnaire for single youth is an attempt to find out your attitudes toward marriage and the home. Your own experiences, ideas, and suggestions will be valuable in helping to plan for stronger and more united homes in the future.

Please fill in every question as far as possible. If there are questions you feel do not apply to you or that you do not care to answer, you may leave them blank. Thank you for taking the time to give this questionnaire your thoughtful attention.

Sincerely yours,

Warren I. Hilliard

Saniku Gakuin College 
F. Data Concerning Single Youth

1. Place a check by your appropriate sex.

\section{Female 2. Male}

2. Into which of the following categories does your age fall?

1. 20 years or under

2. 21-25

3. $26-30$

4. 31-35

3. What is the highest level of education that you have had?

1. Graduated from junior. high school

2. Graduated from senior high school

3. Junior college

4. Specialized school

5. Four-year college

6. Graduate level

7. Other

4. Are you attending or have you in the past attended a Seventh-day Adventist school?

1. No

2. Yes, all my education from grade school up has been in SDA schools

3. Yes, part of my education has been in SDA schools, but not all.

5. What is your present occupation?

1. Student

2. Ronin student

3. Salaried--largely intellectual work

4. Salaried--largely manual work

5. Self-supporting

6. Not employed (sick, etc.)

7. Other (Specify)

9. There have been great changes in the Japanese family in recent years in respect to decision making and authority. Which one of the following statements best expresses your viewpoint?

1. The husband should be the head of the house with absolute, final authority and the wife should follow his leadership in everything. 
2. The wife is equal to the husband and should therefore have equal authority in making al1 decisions with the husband.

3. The husband and wife should share leadership and authority, but the husband should be first among equals with the final decision.

4. Other (Specify)

10. Which of the following do you find most helpful in the development of your spiritual life? Check three that are most helpful.

1. Pastor's sermons

2. Sabbath school classes

3. Prayer meetings

4. Private daily devotions

5. Religious radio programs

6. Reading religious books

7. Counseling with pastor

8. Other (Specify)

11. Formerly Japanese parents had a great deal to do with arranging marriages for their children. Now things are changing. Which of the following best expresses your viewpoint?

1. Decision should be made by individuals involved alone.

2. Decision should be made with parents' advice and approval.

3. Parents should have the power to veto any decision of their children.

4. Parents alone should make the decision.
12. Are you in favor of renai or miai marriage arrangements?

1. Renai

2. Miai

3. Either

13. How important is it to you to marry a Seventh-day Adventist?

1. Very important--I would not marry a non-Adventist.

2. Important--I would not entirely rule out marriage with a non-Adventist.

3. Not very important--as long as my marriage partner would not interfere with my faith and my training the children as Christians.

4. Not important at all.

14. Would you marry someone your parents opposed strongly?

1. No--I would respect their wishes.

2. Yes--I believe marriage is a personal question to decide.

3. It would depend on the reason for my parents' opposition.

4. Other (Specify)

15. If you married a non-Seventh-day Adventist, which of the following do you think is most likely to occur?

1. I would lose my faith eventually, even though I might not leave the church.

2. My spouse would eventually join me as a member of the church.

3. Neither of the above would happen. I would maintain my faith and my spouse would continue to be a nonAdventist.

4. Other (Specify) 
16. When you get married would you think it desirable for the wife to work outside the home?

1. Yes

2. No--it is never desirable.

3. No--not while the children are young and still in the home.

4. Other (Specify)

17. How much is the church doing to help Adventist young people secure Christian mates?

1. Nothing

2. Something--but not enough

3. It is a personal matter. There is nothing the church can do.

4. It is doing all it can do.

18. What suggestions do you have for the church to help our Adventist young people establish Christian homes? Check two suggestions you think are most worthy of consideration. Add any other suggestions you may have.

1. Pastors, teachers, and parents should take more responsibility to arrange Christian marriages.

2. Church leaders should make more opportunities available for Adventist young people to get together in various social and religious activities.

3. The Japan Union Mission should arrange a master file of all Japanese Adventist eligible young people to aid the young people in getting acquainted.

4. Other suggestions 
セブンスデー・アドベンチスト家嵲調查

漫す万青作の皆栐へ

このたび私の神学博士論文のた办の疽料としてての調査にで協力して下さいるす ことを感謝的しをす。

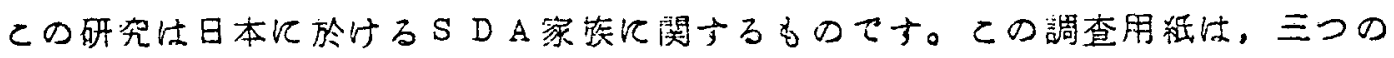
調查のらちの一つて，未嫍者を対象にしています。他の二つの調查仕，牧師を対 象にしたるの，及び全国のアドンンチト家硅を対象札たるのてす。

この調查の目的江。日本の丁トベンチスト家族の実態を知り，現代社会の檬々

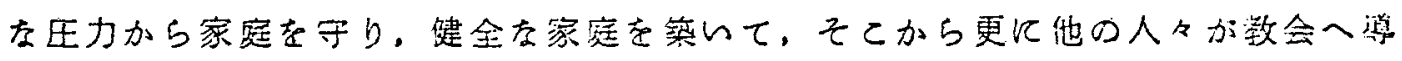

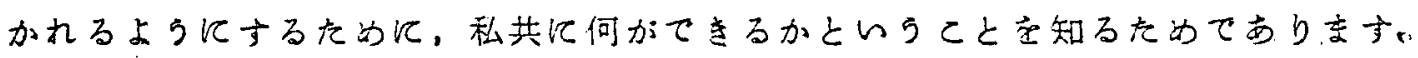

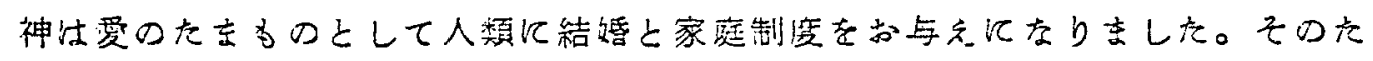

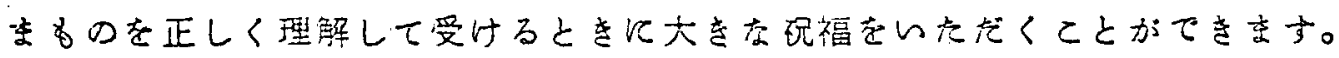

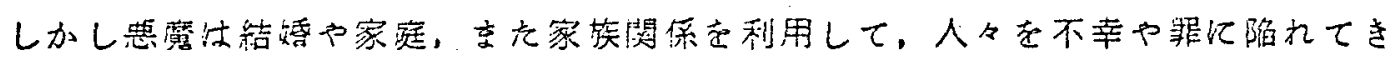
ました。

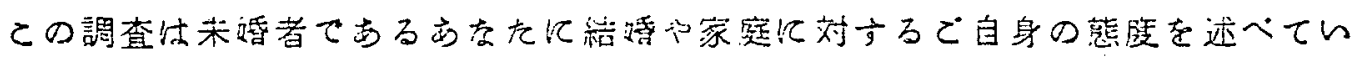

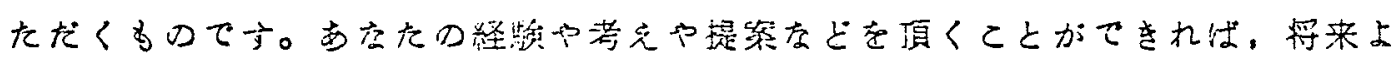

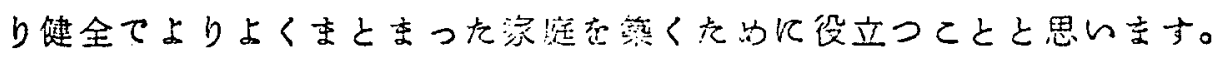

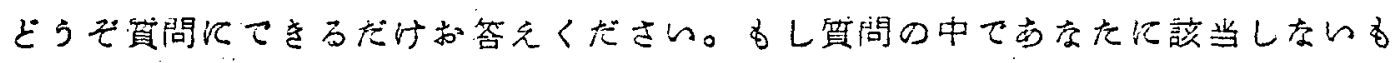

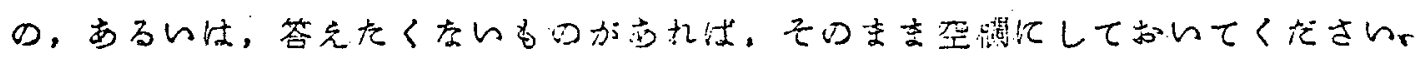

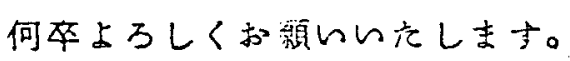

1975 年 12 月 4 日

ウオーレン・I・ヒリヤート

三繁学院カレッシ 
セプンスデー・フト゚ペンチスト家莛調查

未婚者調查 (18オ〜35オ)

質間 1 あなたの性別は…...

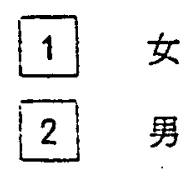

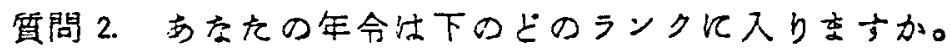
120 オ以下
$2 \quad 21 \sim 25$ オ
$326 \sim 30$ 过
$431 \sim 35$ 才

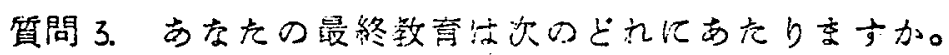
1 中学交卒
2 䓂等学落卒
3 繁大卒
4 各㻎学洨卒
5 四年制大学斈
6 大学院卒
7 その他

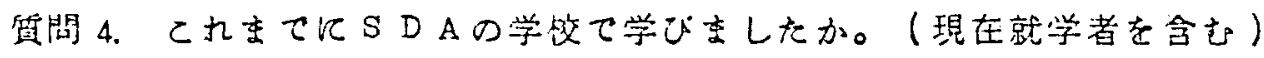
1. nhะ 


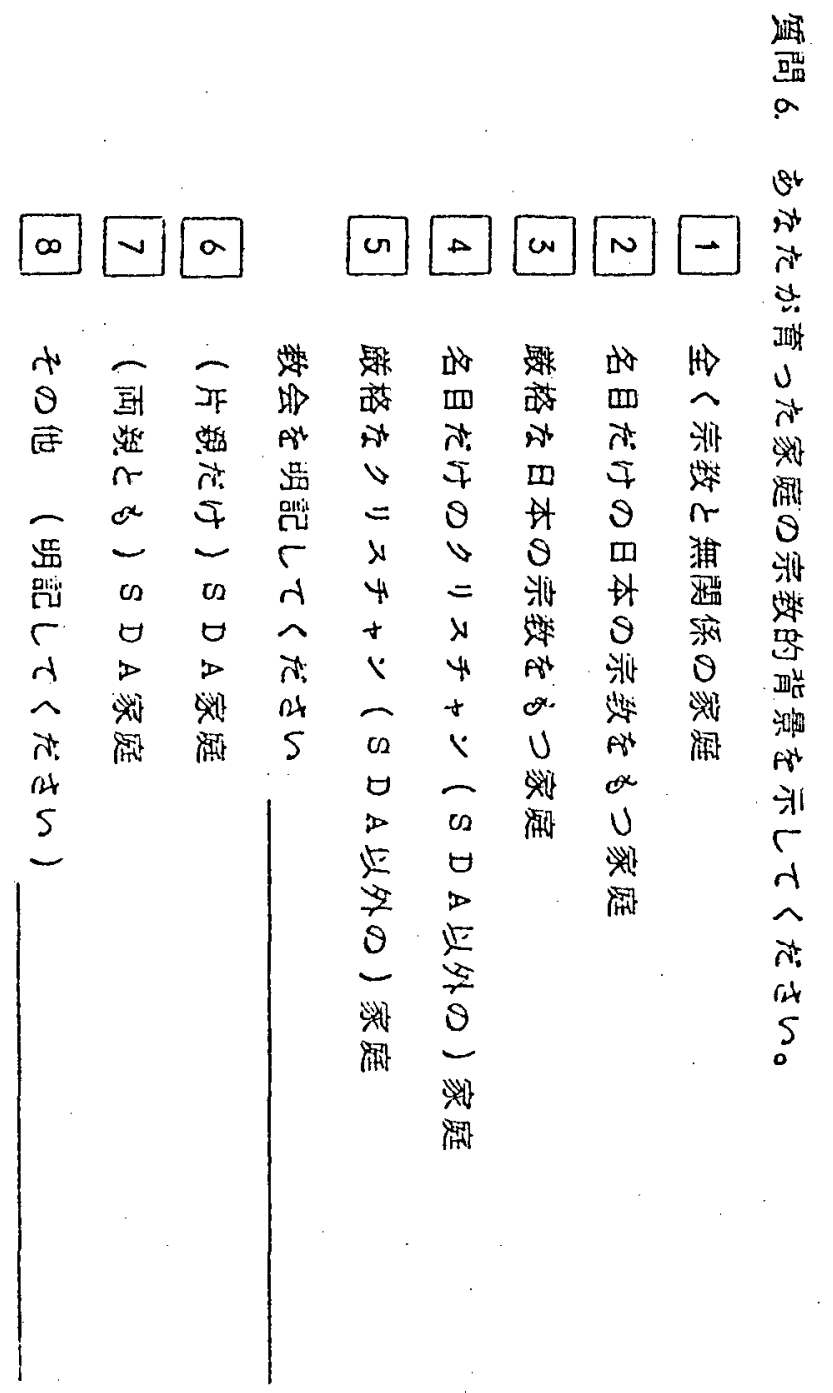




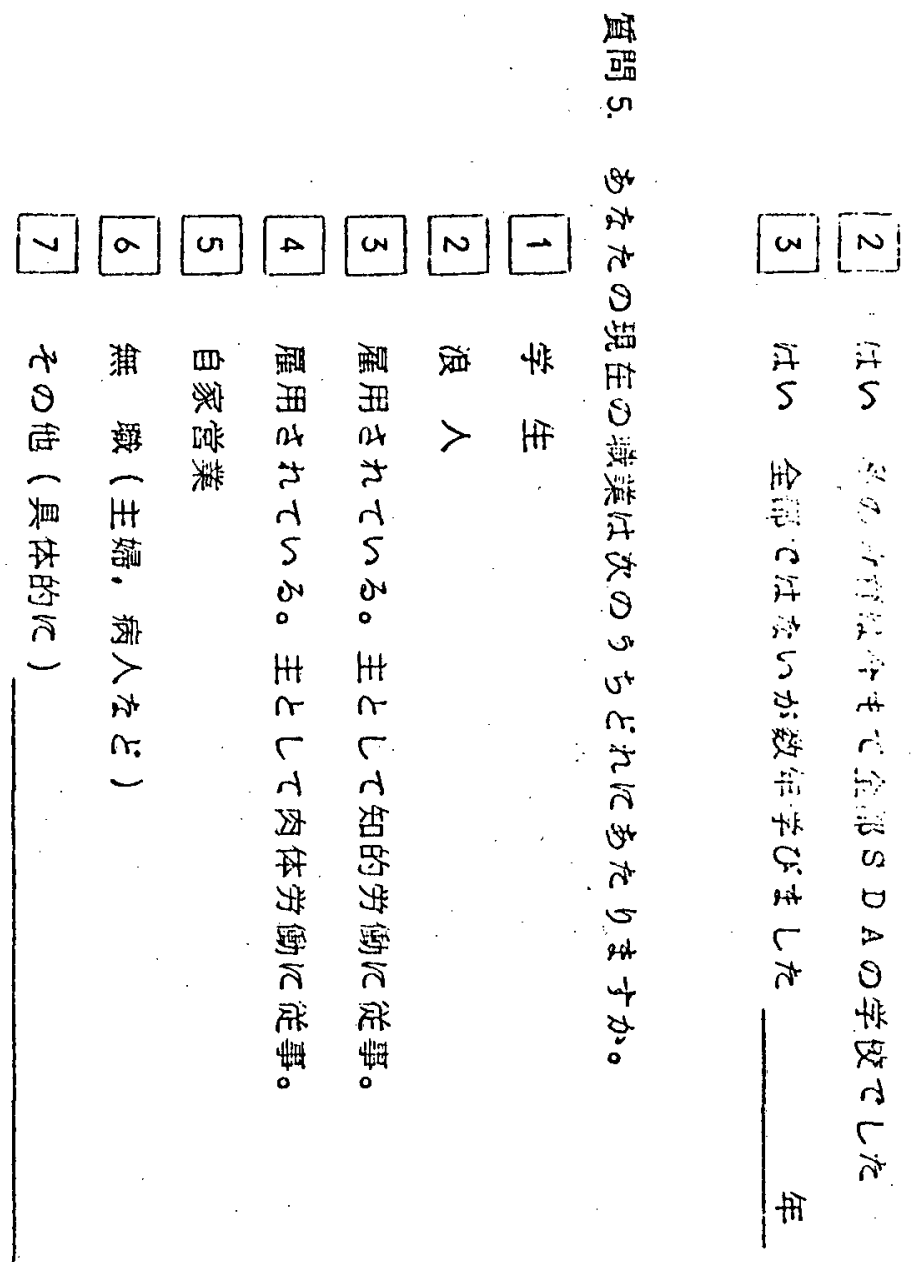




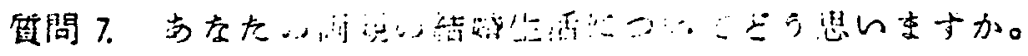

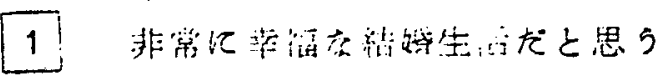

2 比較的福吉絬蚳生活たと思5

3. 比輬的不存結铂生活だ思 5

4 非常に不幸な結嗱生活だと思

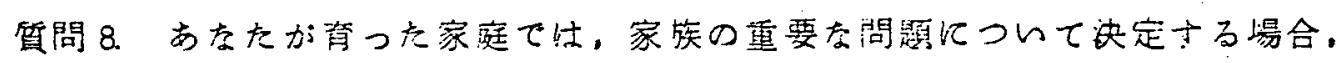

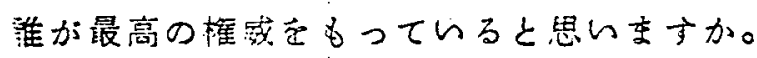
1 bたしの父
2 力たしの母
3 力衣しの祖父
4 bたしの祖母
5 父と母合意
6 漞族会漾
7 その他 (具体的飞)

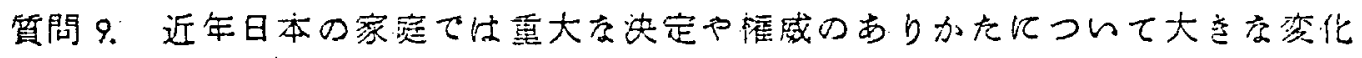
が起っていますが，次の支かてあなたの考允にいちばん近いものをえ らんてくたさん。

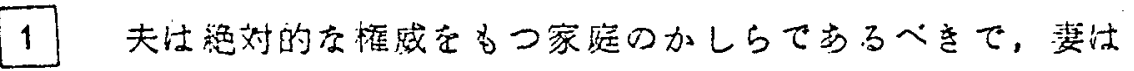

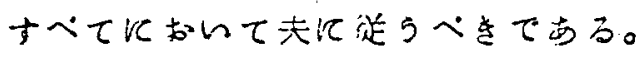

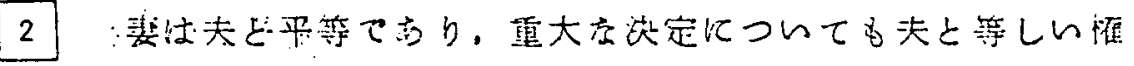
利灾もつべをてある。

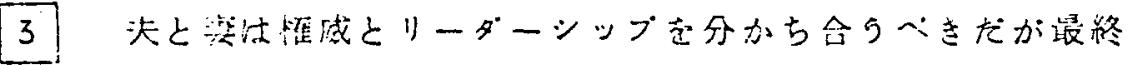

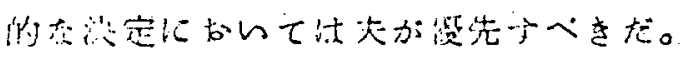

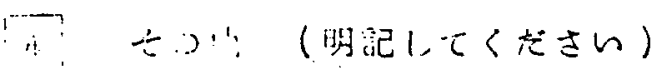




\begin{tabular}{|c|c|c|c|c|c|c|c|c|}
\hline & & & $\begin{array}{l}\frac{\mathrm{m}^{2}}{\mathrm{j}_{\mathrm{m}}^{\mathrm{n}}} \\
\overrightarrow{\mathrm{N}}\end{array}$ & & & & & \\
\hline & & & 醇 & & & & & 5 \\
\hline$w$ & $N$ & $\rightarrow$ & $y$ & $\Delta$ & $w$ & $N$ & $\rightarrow$ & $s^{n}$ \\
\hline & & & al & & & & & 4 \\
\hline 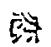 & 证 & EX & 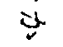 & 面 & 마. & 血 & 따 & 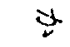 \\
\hline 飄 & a & 新 & $\tilde{a}$ & 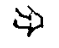 & $\diamond$ & $\Phi$ & $\nLeftarrow$ & $\rightarrow$ \\
\hline d & 5 & $d$ & $u$ & $d$ & $A$ & $\lambda$ & $r$ & \\
\hline$\infty$ & $\theta$ & 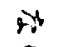 & 5 & $\lambda n$ & 30 & int & to & \\
\hline the & It & $\mp$ & $\lambda$ & $v$ & $v^{2}$ & 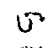 & $v$ & \\
\hline c) $>$ & : & $\exists$ & $i$ & $\pi_{4}$ & 8 & 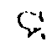 & 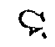 & \\
\hline$\lambda$ & tr & $\bar{A}$ & $n_{i}$ & 4 & $\theta$ & 说话 & 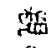 & \\
\hline$\alpha$ & 5 & 5 & $\checkmark$ & tht & 活 & 8 & S & \\
\hline$n$ & & $\mp$ & Jik & $s$ & 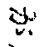 & 메 & $H$ & \\
\hline$v^{*}$ & & $A$ & $3 n$ & 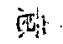 & 闭 & 醮 & $\beta_{5}$ & \\
\hline s & & 5 & ret & ia & 家 & $\mathrm{AH}^{\prime}$ & $a b$ & \\
\hline$A$ & & & 4 & $\overline{\hat{\lambda}}$ & 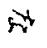 & $\lambda^{n}$ & S & \\
\hline$\infty$ & & & $\not{v}$ & $r$ & $v$ & 0.1 & 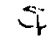 & \\
\hline r r & & & & $\hat{n}^{2}$ & む & & sit & \\
\hline$S$ & & & & $y$ & $\nLeftarrow$ & & 5 & \\
\hline & & & & ur & $0:$ & & & \\
\hline
\end{tabular}


$y$

팝

煤

ง

4

58

sit 縓

$\rightarrow \frac{7}{7}$

- 洒

S

95

ง

it y

n.

$\leftleftarrows$

$\forall y$

B

S 5

ते

$5 \mathrm{H}$

现

[ai 4 tot

$\mathrm{Fit}^{+} \mathrm{C}$

तो

$\ddot{3}$

os 5

9

त 糔

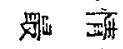

or

酒

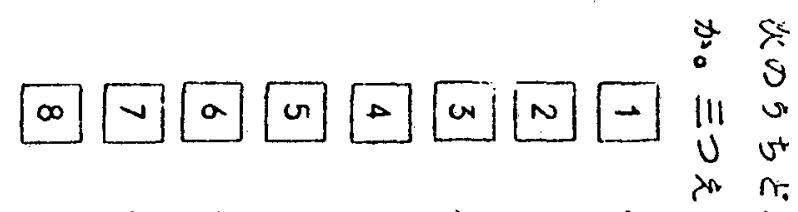

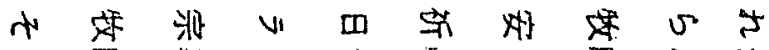

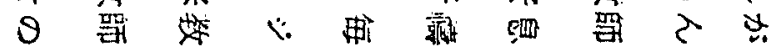

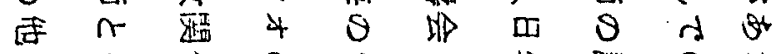

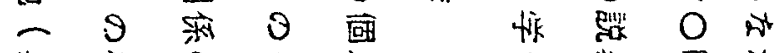

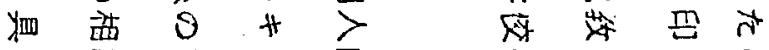

抪 䐴

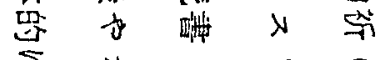

ก

- 18

it if

$v \quad$ 更

4

人研

$\hat{n}_{t} \bar{\lambda}$

at a

$\int_{0}^{\infty} u_{r}$

$\infty$

$\vec{x}$

Kt

u

s

an

n

站

5

iit

$+$ 


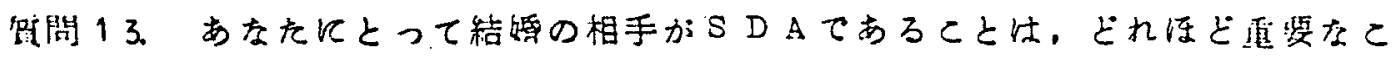
とに思われますか。

1 非常飞重要だ—アドベンチスト以外の人と結婚しない。

2 重要だ一フドヘンチスト以外の人と絶対に結嬏しないと 壮云わない。

3 あまり重要と思わない一結嫖相手がわたしの信仰に干涉 したいなら。

4 全く重要でいと思5。

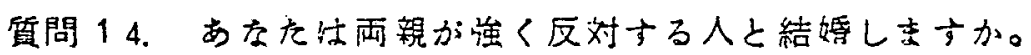

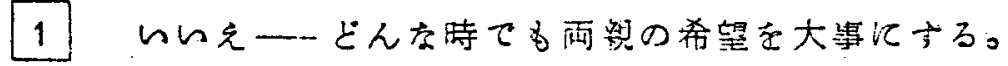

2 結秎恃当人同志の洪定による個人的高問題

3 両琴の反对の理由による

4 その他（明記してくださ）

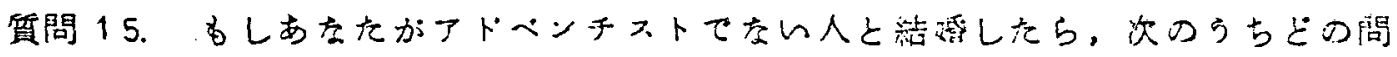
題が生しくゃーんと思い京かか。

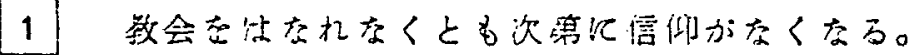

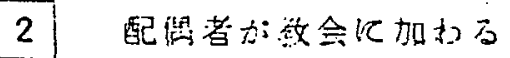

3 互いに干淑しないですでせると思5

4 その他(明記してください)

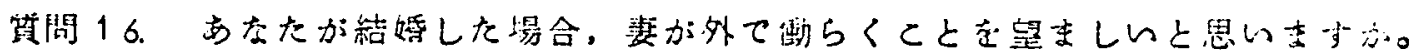
1 注的

2 的望ましくない 


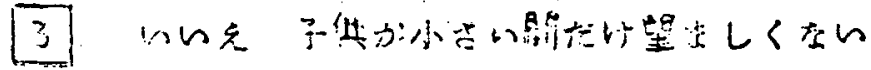

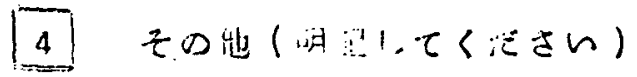

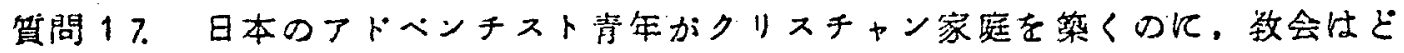
れだけ助けを与えていますか。

1 全く何ししていない

2 少ししているが不十分

3 個人の問题なので教会がでるととは何もないと思5

4 てをるだけの䈌間でよくやっている

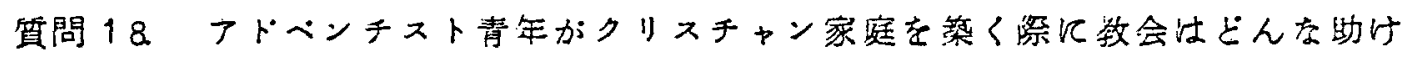
を与えたらよいかについて、西をた壮どら考えすすか。次のなかから 一番よいと思らすのこつえらんでくたさい。

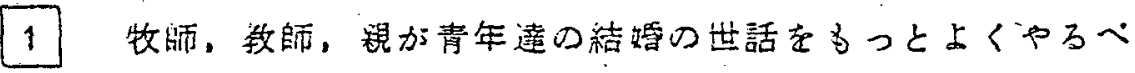
さである。

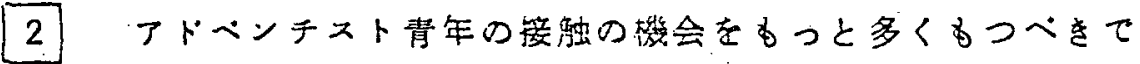
ある。

3 教母がァイルをつくって見合いの浽会をつくってあげる ペをだ。

4]その他のてイデフ 
APPENDIX C

SEVENTH-DAY ADVENTIST MINISTERS SURVEY

Letter of Instructions and Questionnaire in English and Japanese 
A11 ordained and 1icensed

Seventh-day Adventist ministers

in Japan

Dear Fellow Ministers,

The enclosed questionnaire for ministers is one of three that I am using in my study of the Adventist family in Japan. A second questionnaire will be going to every Adventist family in Japan and a third one will be given to a random selection of unmarried Adventist youth.

Without a doubt, the Adventist family, along with families in general, is under serious attack from the many external and internal pressures that come with our modern society. However, we are living in the time just preceeding our Lord's return when the prophecy of Malachai of the turning of the hearts of the fathers to their children and children to their fathers is to be fulfilled. Thus, as a church, we are faced with a grave crisis and also with a tremendous opportunity. I firmly believe that by means of strengthened, united, and Spirit-filled families, God will prepare for and hasten the coming of Christ. It is for this reason that I am studying the Seventh-day Adventist Family in Japan as part of my Doctor of Ministry program.

The purpose of the enclosed questionnaire is to find out what experience, training, and concerns you, as an Adventist minister, have in the area of family ministry and family evangelism. I would also like to find out what you consider to be problem areas in connection with Adventist families and any suggestions or ideas you might have to share.

I appreciate your taking time from your busy program to give this questionnaire thoughtful attention. Please fill in every question as far as possible, not as you wish it were or as you idealize the answer, but in accordance with your experience. If there are questions you feel do not apply to you in your present capacity you may leave them blank. I would appreciate it if you would complete this questionnaire and return it to me within five days after receiving it. Thank you.

Sincerely yours for a spirit-filled ministry,

Warren I. Hilliard

Saniku Gakuin College 
QUESTIONNAIRE FOR ADVENTIST MINISTERS

CONCERNING ADVENTIST FAMILIES

1. Please check the age category into which you fit.

1. 25 years or under

2. $26-30$

3. $31-35$

4. $36-40$

5. 41-45

6. 46-55

7. 56-65

8. 66 years and older

2. What kind of ministerial license do you hold at present?

1. Ordained minister's credentials

2. Licensed minister's credentials

3. What type of employment are you engaged in at present?

1. Church pastor

2. Departmental secretary

3. Administrative officer

4. Educational work

5. Institutiona1, chaplain

6. Retired

4. How many years have you been in the ministry, both as a licensed minister and as an ordained minister?

1. 2 years or less

2. 2-5 years

3. 6-10 years

4. 11-20 years

5. 21-35 years

6. 36 years or more

5. Please check the following areas in which you have had specific training.

1. Psychology

2. Counseling, general

\section{Marriage or family counseling \\ 4. Sex education}

6. How many books in the specialized fields as listed in the preceding question (question 5 ) concerning marriage and the family have you read during the preceding twelve months?
1. None
2. 1-4 volumes
3. 5 or more volumes

7. How many sermons or talks on marriage and the Christian home have you preached during. the past year? Check the particular areas in which you have preached.

\begin{tabular}{|c|l|l|l|}
\hline & None & $\begin{array}{c}1-4 \\
\text { talks }\end{array}$ & $\begin{array}{r}5 \text { or } \\
\text { more } \\
\text { talks }\end{array}$ \\
\hline $\begin{array}{c}\text { Christian } \\
\text { home in } \\
\text { general }\end{array}$ & & & \\
\hline $\begin{array}{c}\text { Marriage } \\
\text { problems } \\
\text { Child } \\
\text { training }\end{array}$ & & & \\
\hline $\begin{array}{c}\text { Family } \\
\text { worship }\end{array}$ & & & \\
\hline Other & & & \\
\hline
\end{tabular}


8. Do you always counsel the couple before performing the marriage service?

1. No, I never do.

2. Sometimes

3. Always

9. In your ministry, do you do much marriage counseling?

1. No, I never do.

2. A little

3. Yes, quite a lot

10. In your ministry, do you do much child-related counseling?

1. No, I never do.

2. A little

3. Yes, quite a lot

11. What do you consider to be the greatest problem areas in the families of your church and those you counsel with? Check three.

1. Infidelity

2. Emotional instability of one or both marriage partners

3. Constant quarreling

4. Financial problems

5. Job-related problems

6. Sabbath-observance problems

7. Problems concerning church standards

8. Discipline and other child-related problems

9. Health-related problems

10. Other (Specify)
13. It is very important that husbands and wives are united in church membership. In the space below write your suggestions for developing and strengthening united Adventist families and for using them to reach non-Adventist relatives and neighbors for Christ.

14. Would you like to obtain specialized training in the areas of marriage and family counseling?

1. No, I do not feel it is necessary.

2. Yes, if there was a good opportunity.

3. I strongly desire to have this training.

12. Do you seek to secure understanding and approval of relatives or the spouse of interested individuals before baptizing them?

1. No

2. Sometimes

3. Always 


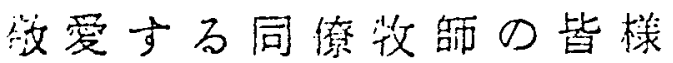

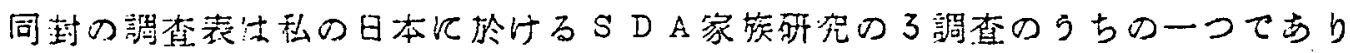

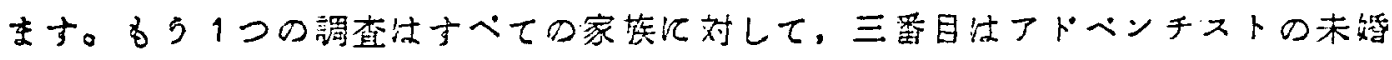
者に抽選で部の人に当てたるので。

確かに現在我々のアトペンチストの家挨は一般の家筷と同怺に我々の住んでい

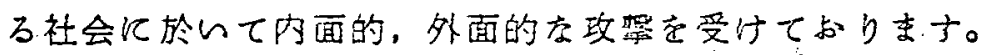

我々は、イエスの再踟に直面している。主わちマラキの預言にあるように

"父の心を子供たちに向けさせ，子供たちの心をその父に向けさせる( マラキ4

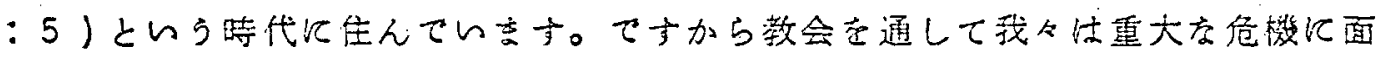

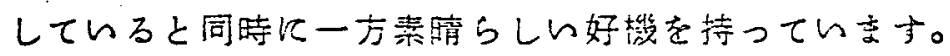

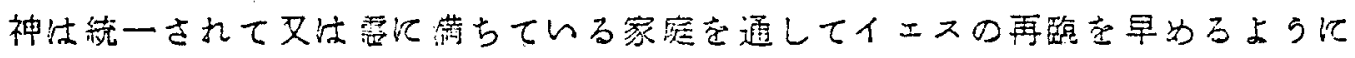

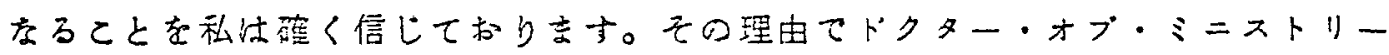

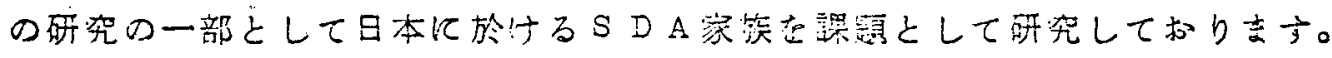

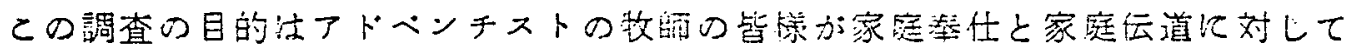

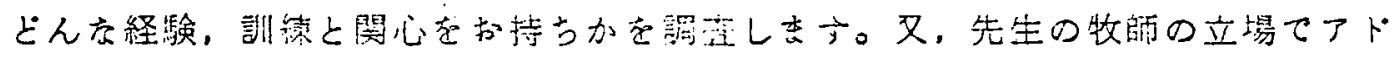

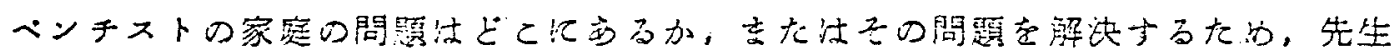
の経跧，ど是案を晾司いします。

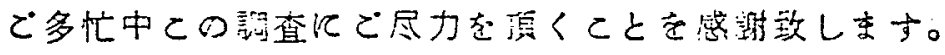

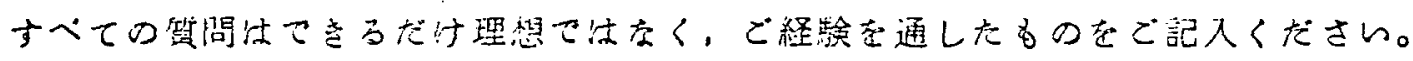

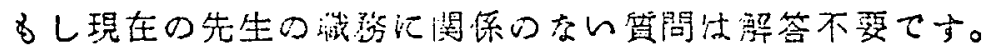

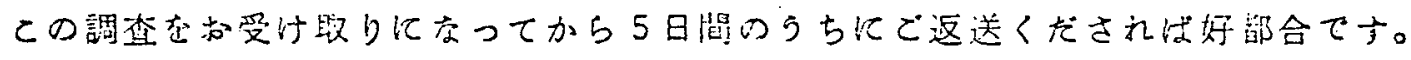

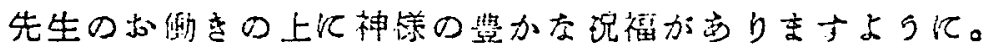

1975 年 12 月 5 日

三等学筦カレッシ

W. I. ヒท+ート 
セブンスデー・アドベンチスト家继调査

牧晦調、查

次の質問の適当吉すのに○印をつけてください。

罂問
(1) 25 才以下
$5 \quad 41 \sim 45 \pi$
2 26 30才
$646 \sim 55 才$
$3 \quad 31 \sim 35 才$
$756 \sim 65 t$
$436 \sim 40 x$
866 才是上

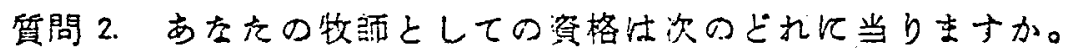

1 势手礼を受㤋充信任状をる

2]教団加叫的補としての承䦀状をる?

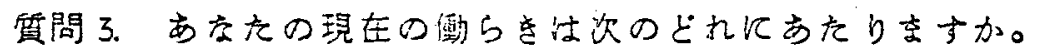

1 教会牧稬

2 部局勤䇨

3 教团及び渻関行政践 (Officers)

4 教 師

5 機関働さ人(チャブレンを含さ)

6 引退充壮その他

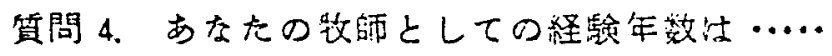
112 年末满
$4 \quad 11$ 年以上 20 年李て
22 年以上 5 年立て
521 年以上3 5 年业て
3 6年以上 10 年まて
636 年以上 


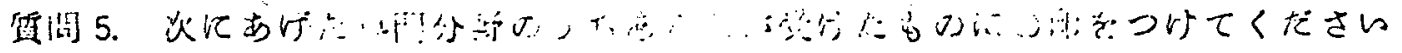

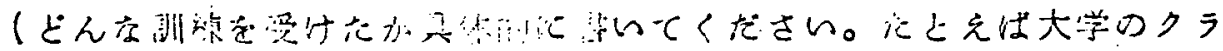

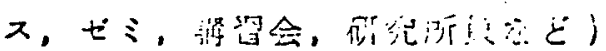

1 心理学

2 - 没のカンセリンク

[3 結嫖む恃家族のカンセリンク

4 珄教育

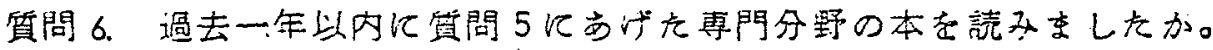

1 . 読みさせん

2 数冊㜔みした $(1 \sim 4$ 冊)

3 多数読みました ( 5 冊以上)

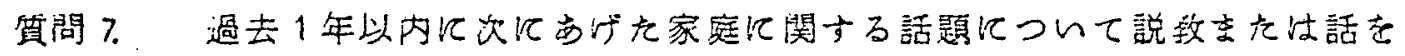
しましたか。

した項目の右の稆に○印をつけてください。

1.クリスチャン家宛の重要性 .

2. 夫婟関倸

3.子低の教管

4. 家庭礼排

5. その他，傢经付する話 ..

\begin{tabular}{|c|c|c|}
\hline しません & $\begin{array}{l}\text { 数回し克した } \\
\text { (1回〜回) }\end{array}$ & 多㜟回し党した \\
\hline & & \\
\hline & & \\
\hline & & \\
\hline & & \\
\hline & - & \\
\hline
\end{tabular}


7 教会の焦隹を守らないてと

8 子供のしつけ,あるい洁非阔频

9) 格の不一致

10 その他（具体的に）

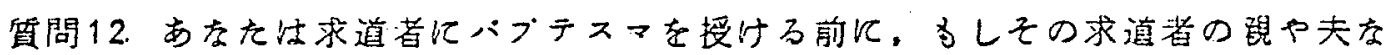

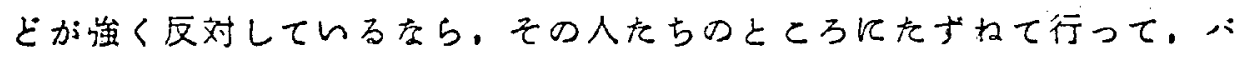

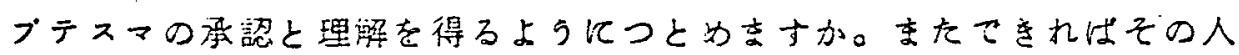

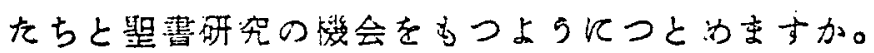

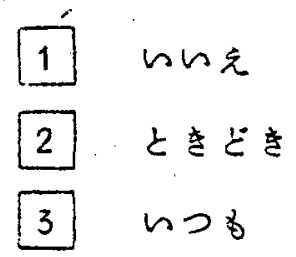

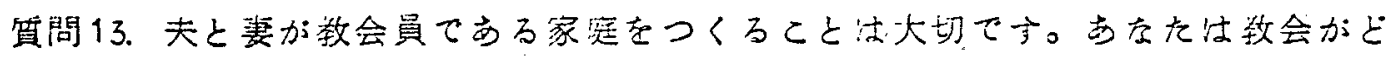

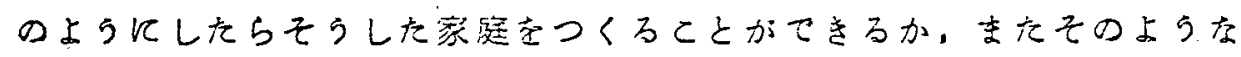

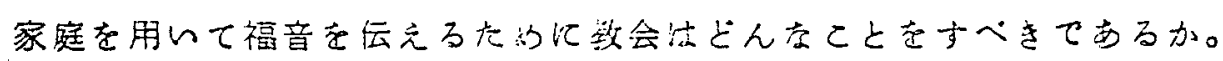
あなたのど意見をお菁喜ください。

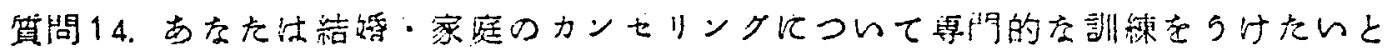
思にますか。

1 受けなくてるよい

2 政会があれば受けたい

3 必嬖を感しているのてぜひうけたい

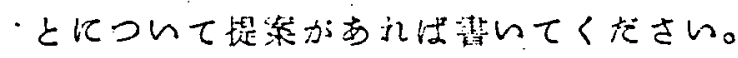




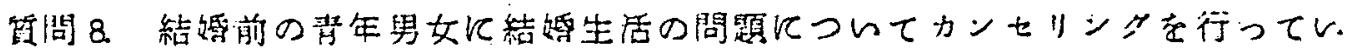

京子か。

1 nง

2]壮ん，行ってい主す

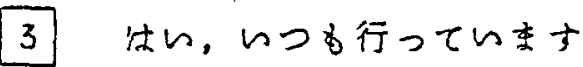

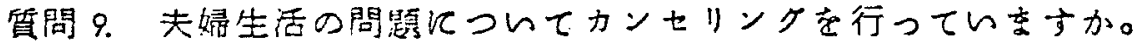

$1 \sin$

2 壮ん, 少し行い立す

3. 壮い, 多く行います

啠問 10 䪭子の問題につんてカンセリンクを行ってい屯すか。

1 und

2 沐い, 少し行います

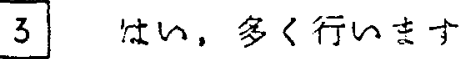

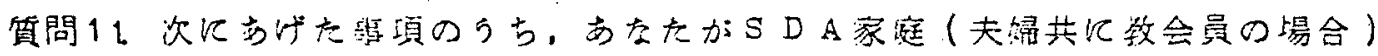

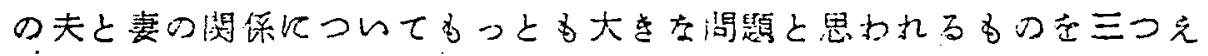
らんで○卵をつけてだん。

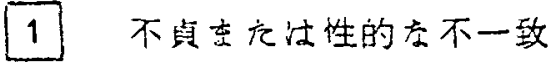

2 夫加辈あるい江雨方の感情が不安定

3 た立支い口論

4 経済间題

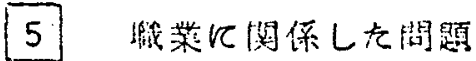

6 安息日道守問题 
APPENDIX D

\section{CHURCH MEMBERSHIP FAITHFULNESS SURVEY}

Letter of Instructions and Sample Information Blank 
The following request for cooperation and instructions concerning the Membership Faithfulness Survey was not sent to the pastors in letter form. It was explained to them either personally or, in some cases, by telephone.

July and August, 1976

Dear Pastor,

Your cooperation is needed to help complete a study of the Seventh-day Adventist family in Japan. I would greatly appreciate it if you would fill out the enclosed blanks, checking the appropriate columns for every member listed on your church records, regardless of his or her faithfulness in church attendance. There are three things I would like to know regarding each member: whether the member is male or female; whether he or she is a spouse of a united family, that is, a family in which both husband and wife are church members; and what is your evaluation as to the member's faithfulness to the church.

I realize that it is very difficult to evaluate faithfulness. The following definitions are given as a guide to help you. Check faithful if the member attends services of the church regulariy when at all possible and if he participates in church activities, and supports the church by word, action, and offerings. Of course, when the merber is sick, old, traveling, or otherwise unable to attend, his absence is understandable. Check lukewarm if the member attends services only rarely, if he fails to support the church on a regular basis with his tithes and offerings, and if his behavior is not entirely in harmony with Seventh-day Adventist church standards. Check backslidden if the member, although listed as a church member, never attends services and fails to support the church by word, action, or by his offerings.

Thank you for your cooperation. The purpose of this survey is to discover the relationship, if any, between faithfulness in church membership and the sex and family-relatedness of the member. Please send the completed blank to me as soon as possible.

Sincerely,

Warren I. Hilliard

Saniku Gakuin College 
CHURCH MEMBERSHIP FAITHFULNESS SURVEY

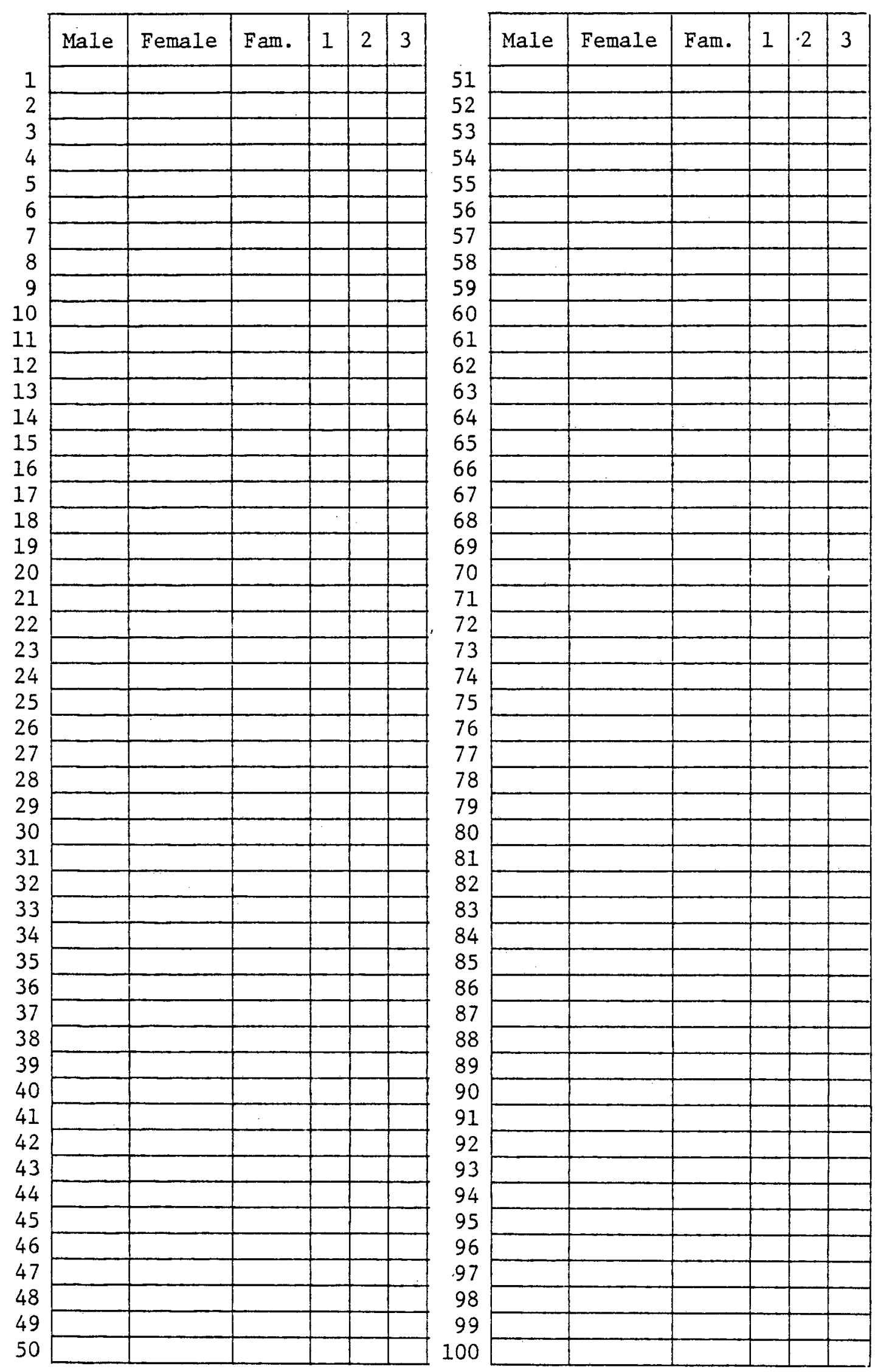

KEY: 1 = Faithful 2 = Lukewarm 3 = Backslidden 
B. I B L I O G R A P H Y 


\section{BIBLIOGRAPHY}

\section{Books}

Aikawa, T. The Mind of Japan. Valley Forge: The Judson Press, 1967 .

Anesaki, Masaharu. Histories of Japanese Religions, with Special Reference to the Social and Moral Life of the Nation.

Tokyo: Charles E. Tuttle Co., 1963.

- History of Japanese Religions. London: Kegan, Paul, Trench, Trubner and Co. Ltd., 1930.

Ariga, Kizaemon. Nihon no Kazoku. Tokyo: Shibundo, 1965.

Baber, Ray E. Youth Looks at Marriage and the Family. Tokyo: International Christian University, 1958. - Japanese Religious Attitudes. Marykno11, N.Y.: Orbis Books, 1972 .

Basabe, Fernando. Japanese Youth Confronts Religion. Tokyo: Sophia University, in co-operation with Charles E. Tuttle Co., 1967.

Beardsley, Richard K.; Hall, John W.; and Ward, Robert E. The Household. Chicago: University of Chicago Press, $\overline{1959}$.

Bellah, Robert N. Tokugawa Religion: The Values of Pre-Industrial Japan. New York: Freee Press, 1969.

Ben-Dasan, Isaiah. The Japanese and the Jews. New York: Weatherhil1, 1972 .

Benedict, Ruth Fulton. The Chrysanthemum and the Sword. Boston: Houghton Mifflin, 1946.

Bennet, John W.; Passin, Herbert; and McKnight, Robert K. In Search of Identity. Minneapolis: The University of Minnesota Press, 1955.

Best, Earnest E. Christian Faith and Cultural Growth: The Japanese Case. Leiden: E. J. Brill, 1966. 
Boschman, Paul W., ed. Experiments in Church Growth: Japan. Tokyo: New Life League, 1968.

Braun, Neil. The Laity Mobilized: Reflections on Church Growth in Japan and Other Lands. Grand Rapids: Eerdmans, 1971.

Buck, Pear1 S. The People of Japan. New York: Simon and Schuster, 1966.

Carr, Lowell J. Introductory Sociology. New York: Charles Scribner's Sons, 1933.

Craig, Albert M., and Shively, Donald. Personality in Japanese History. Berkeley, Calif.: University of California Press, 1970.

Dale, Kenneth J. "An Investigation of the Factors Responsible for the Impact of Hoza of Rissho Kosei-kai as a Means of Religious Propagation in Contemporary Japan." Th.D. dissertation, Union Theological Seminary, New York, 1970.

Doi, Takeo L. "Amae: A Key Concept for Understanding Japanese Personality Structure." In Japanese Culture, Its Development and Characteristics. Edited by Robert J. Smith and Richard Beardsley.

Drummond, Richard H. A History of Christianity in Japan. Grand Rapids, MI.: Eerdmans, 1971.

Elison, George. Deus Destroyed, The Image of Christianity in Early Japan. Cambridge, Mass.: Harvard University Press, 1973.

Endo, Shusaku. Silence. Tokyo: Charles E. Tuttle Co., 1969.

Germany, Charles H., ed. The Response of the Church in Changing Japan. New York: Friendship Press, 1967.

Goode, William J. The Family. Englewood Cliffs, New Jersey: Prentice Hall, Inc., 1964.

Gubbins, John H. The Making of Modern Japan. Freeport, New York: Books for Library Press, 1971.

Hall, John Whitney, and Beardsley, Richard. Twelve Doors to Japan. New York: McGraw-Hil1 Book Co., 1965.

Haring, Douglas G. Personal Character and Cultural Milieu. Syracuse: Syracuse University Press, 1956.

Hearn, Lafcadio. Japan, An Attempt at Interpretation. Tokyo: Charles E. Tuttle Co., 1955. 
Hill, Reuben and Konig, Rene. Families in East and West. The Hague: Mouton and Co., 1970.

Hori, Ichiro. "The Appearance of Individual Self-Consciousness in Japanese Religion and Its Historical. Transformations." In Robert J. Smith. Ancestor Worship in Contemporary Japan. Stanford, Calif.: Stanford University Press, 1974.

Iglehart, Charles W. A Century of Protestant Christians in Japan. Tokyo, Japan: Charles E. Tuttle Co., 1959. - Cross and Crisis in Japan. New York: Friendship Press, 1957 .

Ishida, Eiichiro. Japanese Culture, A Study of Origins and Characteristics. Honolulu: The University Press of Hawaii, 1974.

Ishida, Takeshi. Japanese Society. New York: Random House, 1971. Japan Statistical Yearbook. Tokyo: Japan Statistical Assoc., 1976. Japan Times. August 16, 1975.

Kawashima, Takeyoshi. The Familial Structure of Japanese Society. Tokyo: Nippon Hyoronsha, 1948.

Keesing, Felix M. Cultural Anthropology. New York: Holt, Rinehart and Winston, 1966.

Kirisutokyo Nenkan. Tokyo: Kirisuto Shimunsha PubI. Co., 1976.

Kirkpatrick, Clifford. The Family as Process and Institution, 2nd ed. New York: The Ronald Press Co., 1963.

Kitagawa, Joseph Mitsuo. Religion in Japanese History. New York: Columbia University Press, 1966.

Kitamori, K. Theology of the Pain of God. Baltimore, Maryland: John Hopkins University Press, 1965.

Kitano, Seiichi. "Dozoku and Ie in Japan: The Meaning of Family Genealogical Relationships." In Japanese Culture, Its Development and Characteristics. Edited by Robert J. Smith and Richard Beardsley. Chicago: Aldine Publishing Co., 1962 .

Koyama, Takashi. "Changing Family Structure in Japan." In Japanese Culture, Its Development and Characteristics. Edited by Robert J. Smith and Richard Beardsley. Chicago: Aldine Publishing Co., 1962. 
Lanham, Betty B. "Aspects of Child Care in Japan: Preliminary Report." In Personal Character and Cultural Milieu. Edited by Douglas G. Haring. Syracuse, New York: Syracuse University Press, 1956.

Lawson, Kate. Highways and Homes of Japan. New York: Frederick A. Stokey Co., 1910.

Lebra, Taki Sugiyama and Lebra, William P., eds. Japanese Culture and Behavior. Honolulu: The University Press of Hawaii, 1974.

Lee, Robert. Strangers in the Land. London: Lutterworth Press, 1967.

Matsubara, Haruo. Gendai no Kazoku. Tokyo: Nihon Keizai Shimbunsha Co., 1964.

Matsumoto, Yoshiharu Scott. Contemporary Japan: The Individual and the Group. Philadelphia: Transactions of the American Philosophical Society, New Series, Vol. 50, Part 1, 1960.

McQuilkin, J. R. Measuring the Church Growth Movement. Chicago: Moody Press, 1974.

Minami, Hiroshi. Psychology of the Japanese People. Toronto: University of Toronto Press, 1971.

Moore, Charles A., ed. The Japanese Mind. Honolulu: University of Hawaii Press, 1967.

Munakata, Gan. Nihon no Kazoku Seido no Hensen to Toshika. Shakai Kyoku Series, no. 8. Tokyo: Jochi Daigaku Press, 1968.

Nakamura, Hajime. Ways of Thinking of Eastern People. Honolulu: East-West Center Press, 1964.

Nakane, Chie. Japanese Society. London: Wiedenfeld and Nicholson, 1970.

Nida, Eugene A. Message and Mission. New York: Harper and Row, 1960.

Nitobe, Inazo. The Japanese Nation: Its Law, Its People and Its Life. New York: S. P. Putnam Sons, 1912.

Norbeck, Edward. Changing Japan. New York: Holt, Rinehart and Winston, 1965 .

Ono, Sokyo. Shinto, the Kami Way. Tokyo: Charles E. Tuttle, 1962. 
Oosterwal, Gottfried. Patterns of SDA Growth in America. Berrien Springs, Michigan: Andrews University Press, 1976.

Reischauer, Edwin 0. Japan: Past and Present. New York: Alfred A. Knopf, 1946 .

Sakamaki, Shunzo. "Shinto: Japanese Ethnocentrism." In The Japanese Mind: Essentials of Japanese Philosophy and Culture. Edited by Charles A. Moore. Honolulu: University of Hawaii Press, 1971.

Saniel, Josefa M. "The Mobilization of Traditional Values in Modernization of Japan." Religion and Progress in Modern Asia. New York: The Free Press, 1965.

Sano, Chiye. Changing Values in the Japanese Family. Washington, D.C.: Catholic University of America Press, 1958.

Sansom, George B. Japan, A Short Cultural History. New York: D. Appleton-Century Co., 1943. - The Western World and Japan. New York: Alfred A. Knopt, 1951.

Shively, Donald H. Tradition and Modernization in Japanese Culture. Princeton, New Jersey: Princeton University Press, 1971.

Silberman, Bernard S., ed, Japanese Character and Culture. Tucson, Arizona: The University of Arizona Press, 1962.

Smith, Robert J. Ancestor Worship in Contemporary Japan. Stanford, Calif.: Stanford University Press, 1974.

and Beardsley, Richard K. Japanese Cultures, Its Development and Characteristics. Chicago: Aldine Publishing Co., 1962.

Spae, Joseph J. Christian Corridors to Japan. Tokyo: Oriens Institute for Religious Research, 1967.

- Christianity Encounters Japan. Tokyo: Oriens

Institute for Religious Research, 1967.

- Japanese Religiosity. Tokyo: Oriens Institute for Religious Research, 1965.

Stead, Alfred, ed. Japan by the Japanese. New York: Dodd, Mead and Co., 1904 .

Suyematsu, Kencho. The Risen Sun. New York: E. P. Dutton and Co., 1905. 
Takenaka, Masao. Reconciliation and Renewal in Japan. New York: Friendship Press, 1967.

Tsurumi, Kazuko. Social Change and the Individual. Princeton, New Jersey: Princeton University Press, 1970.

White, Ellen G. Adventist Home. Nashville, Tenn.: Southern Publishing Association, 1952.

- Counsels to Parents and Teachers. Mountain View, Calif.: Pacific Press Publishing Association, 1942.

- Ministry of Healing. Mountain View, Calif.: Pacific Press Publishing Association, 1943.

- Testimonies for the Church. 9 Volumes. Mountain View, Calif.: Pacific Press Publishing Association, 1948.

Yamamori, Tetsunao. "Church Growth in Japan." Th.D. dissertation, Duke University, Durham, North Carolina, 1970.

Yanagita, Kunio. About Our Ancestors: The Japanese Family System. Tokyo: Japan Society for the Promotion of Sciences, 1970.

\section{$\underline{\text { Periodicals }}$}

Dale, Kenneth J. "Religion and Culture in Contemporary Japan: Buddhist and Christian Perspectives." Northeast Asia: Journal of Theology, Sept. 1973.

Goh, Daigoro. "Family Relations in Japan." Transactions of the Japan Society 11 (1892-1893).

Hiyakawa, S. I. "The Decision Making Process in Japan." The Chicago Tribune, April 23, 1972.

Kawashima, Tokoyoshi. "The Familial Structure of Japanese Society." Southwest Journal of Anthropology 9 (1953):239-250.

Kumazawa, Y. "Confessing the Faith in Japan." Journa1 of Theology $8(1966): 161$.

Masuoka, Jitsuichi. "Urbanization of the Family in Japan." Sociology and Social Research 32 (1947):535-539.

Matsumiya, Kazuya. "Family Organization in Present-day Japan." American Journal of Sociology 53 (1947):105-110

Matsuzawa, Kazuko. "Japanese Social Structure and the State of Women." Japan Christian Quarterly, Spring, 1974. 
Morioka, Kiyomi and Newe1l, William H. "The Sociology of Japanese Religions." Journal of Asian and African Studies 3, Nos. 1 and 2,1968 .

McQuilkin, J. R. "Japanese Values and Christian Mission." Japan Christian Quarterly, Fall, 1967.

Pittau, Joseph. "The Role of Christianity in Promoting Individual Values in Japan." Japan Christian Quarterly, Winter, 1973.

Reischauer, Edwin Q. "The Japanese Character." The US and Japan, 1950, pp. 99-204.

Sato, Kennosuke. "The Changing Japanese Woman." Contemporary Japan, Sept. 1934 .

Taeuber, Irene B. "Family, Migration and Industrialization." American Sociological Review 16 (April 1957).

Taylor, Archibald B. "Liberation for Women: A Biblical View." Japan Christian Quarterly, Spring, 1974.

Tuggy, A. Leonard. "You and Your Household." Theology, News and Notes, Dec. 1974.

Woodward, William. "Communicating the Gospel in the Japanese Cultural Context." Japanese Christian Quarterly, July 1964. 
VITA

Warren Ivan Hilliard

January 1977

Born in central China on March 7, 1922 of Seventh-day Adventist missionary parents, Warren Hilliard received all his elementary and high school education in the Far East. In 1945 he graduated with a Bachelor of Arts in Theology from Pacific. Union College and received a Master of Arts degree in Religion in 1955, a Master of Divinity degree in 1969, and a Doctor of ministry degree in 1977, a11 from Andrews University in Berrien Springs, Michigan. He married Norma Landis, a daughter of missionary parents, in 1946; and they have four daughters, all born in the Far East, one of whom is at present serving as a missionary with her doctor husband in Africa.

He served as assistant pastor in several churches in central California and as pastor of a Seventh-day Adventist church in Hong Kong before transfering to Japan as a result of political turmoil in China. During more than twenty-seven years in Japan, he has served as district leader, evangelist, leader of the young people's and lay activity departments of the Japan Union Mission, and administrator of various mission organizations. At present he is teaching in the theology department of Saniku Gakuin College, a Seventh-day Adventist college in Chiba Prefecture, Japan. 